
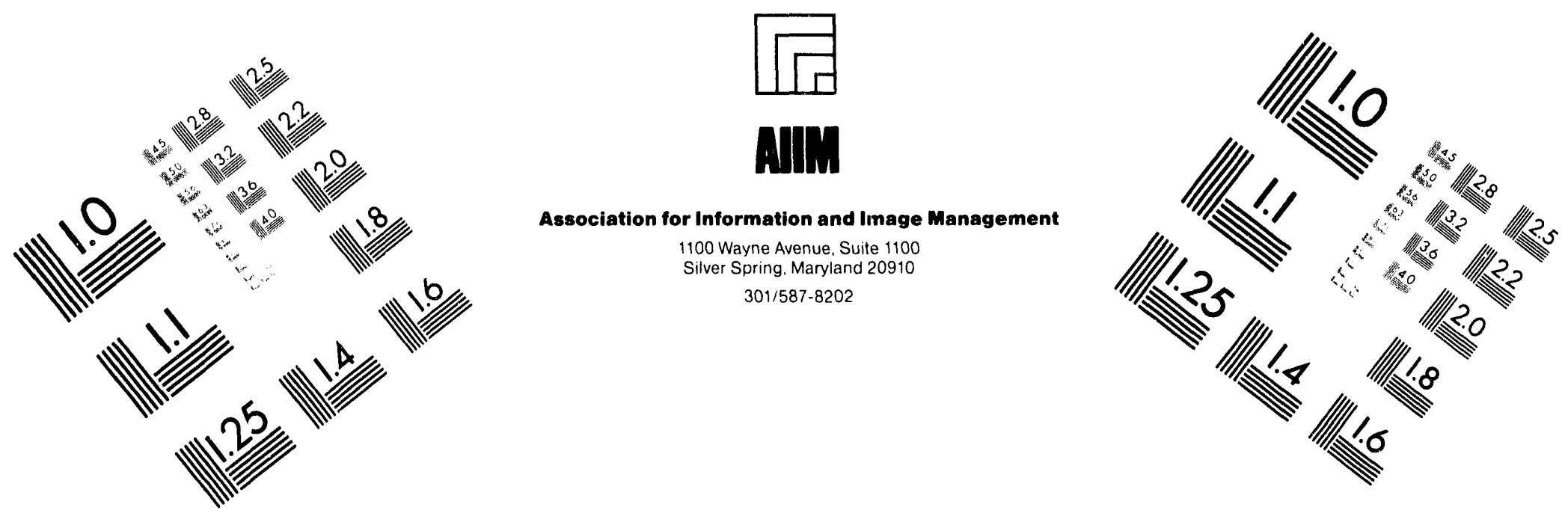

Centimeter

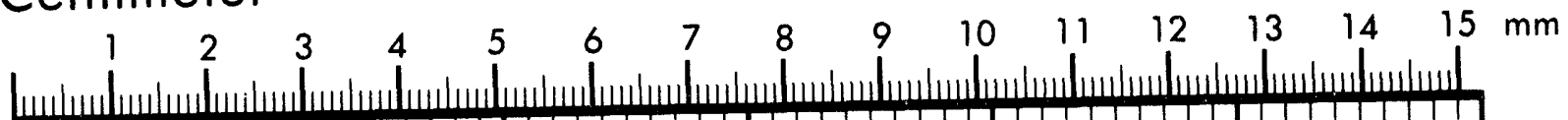

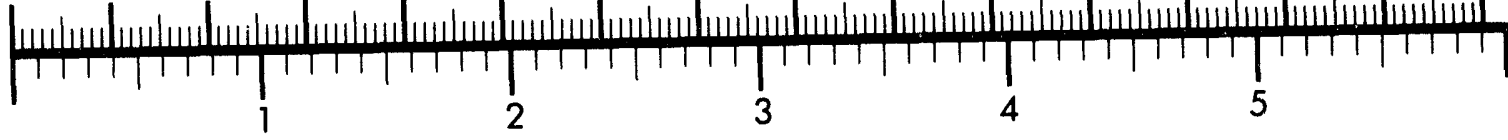
Inches
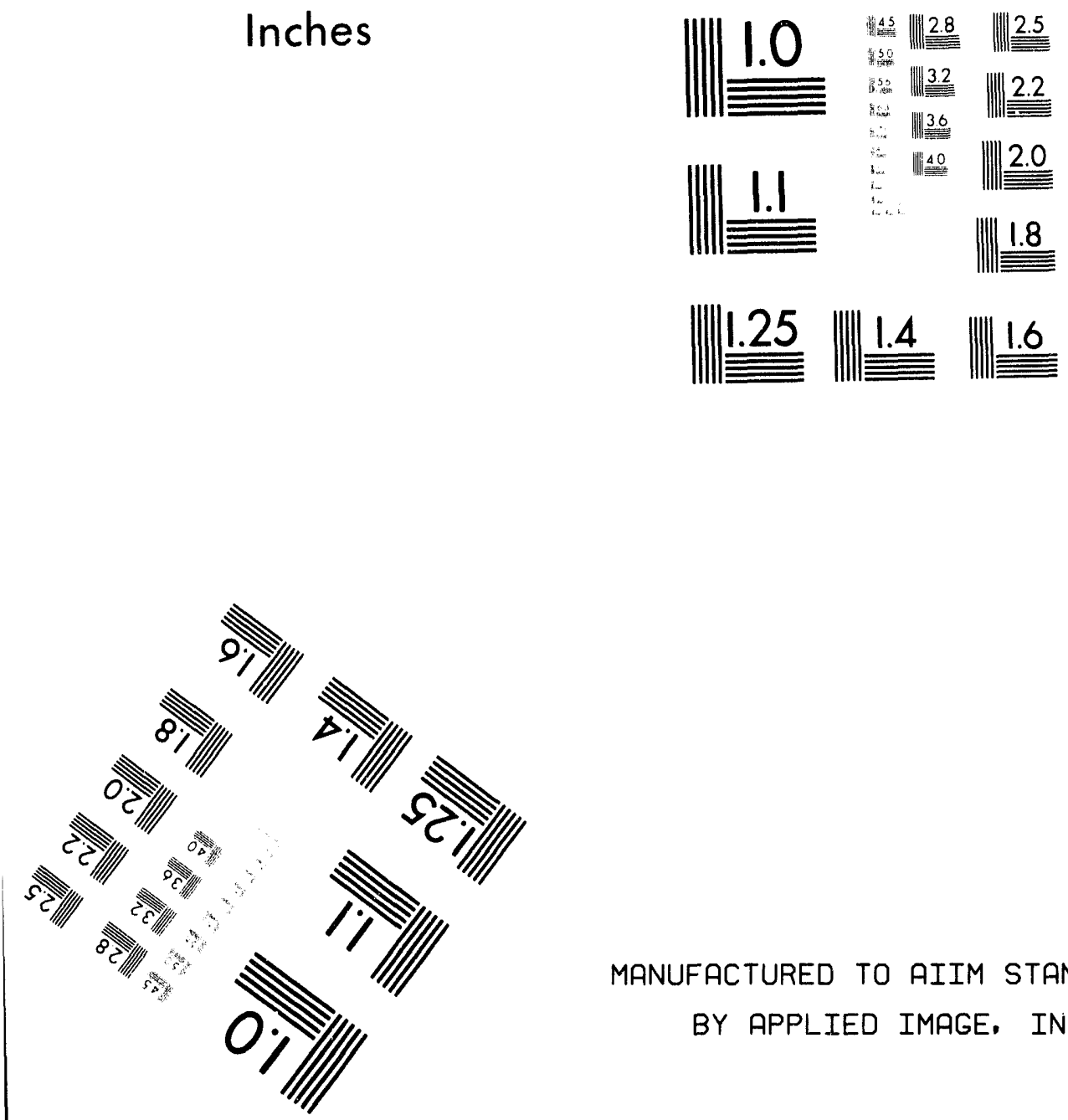

MANUFACTURED TO AIIM STAN!DARDS

BY APPLIED IMAGE. INC.

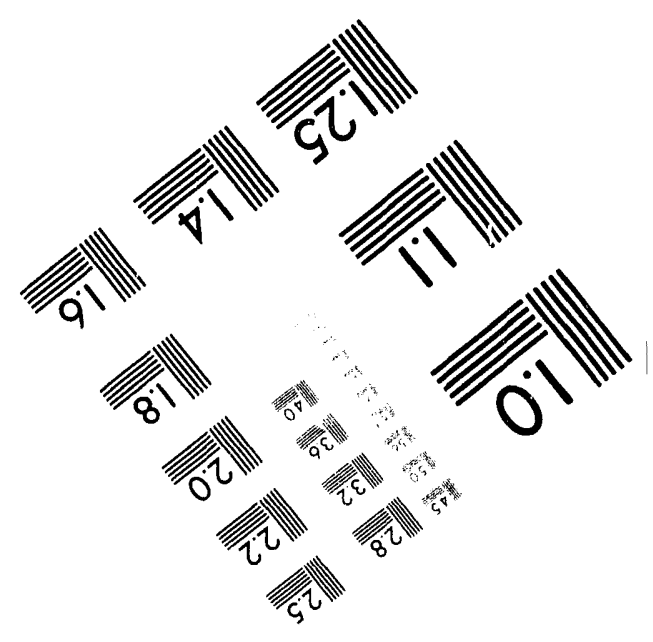



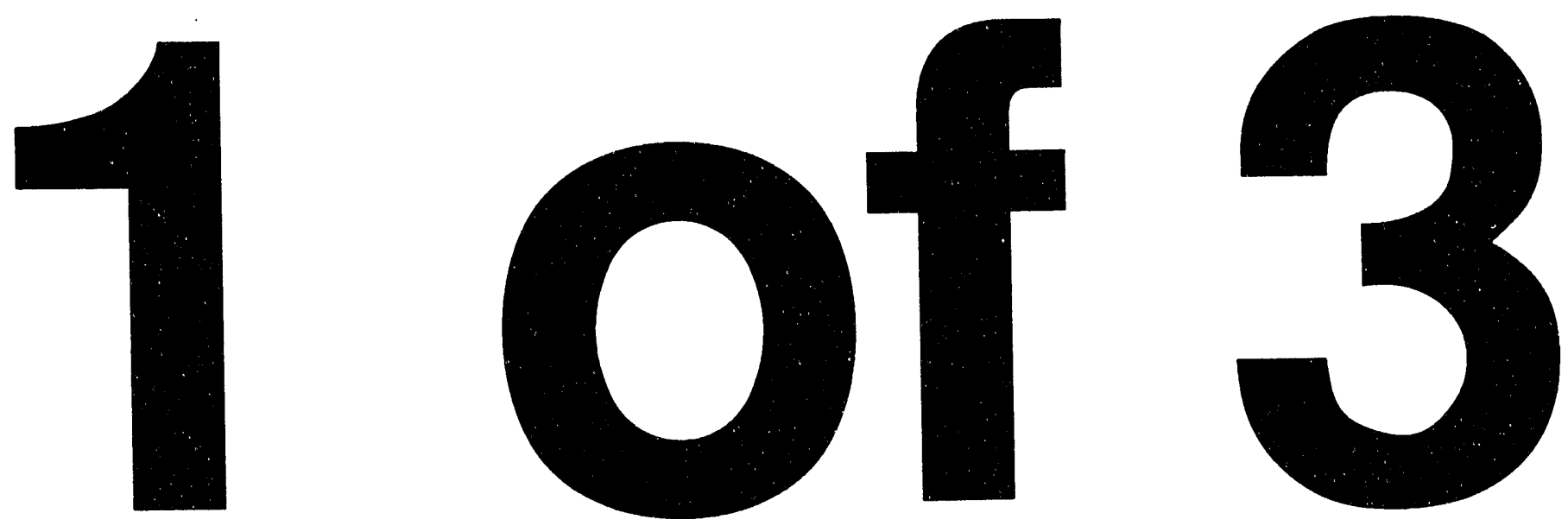


\title{
AGING MANAGEMENT GUIDELINE FOR COMMERCIAL NUCLEAR POWER PLANTS- HEAT EXCHANGERS
}

\author{
Prepared by: \\ MDC-Ogden Environmental and Energy Services \\ 29200 Southfield Road, Suite 103 \\ Southfield, MI 48076
}

Sandia Contract No. $87-5521$

Authors:

Stephen Booker, Daniel Lehnert, Neil Daavettila and Esther Palop

Under Contract to:

Sandia National Laboratories

Albuquerque, NM 87185

for the

U.S. Department of Energy

Project Manager:

James Nakos

\begin{abstract}
This Aging Management Guideline (AMG) describes recommended methods for effective detection and mitigation of age-related degradation mechanisms in commercial nuclear power plant heat exchangers important to license renewal. The intent of this AMG is to assist plant maintenance and operations personnel in maximizing the safe, useful life of these components. It also supports the documentation of effective aging management programs required under the License Renewal Rule 10 CFR 54. This AMG is presented in a manner that allows personnel responsible for performance analysis and maintenance to compare their plant-specific aging mechanisms (expected or already experienced) and aging management program activities to the more generic results and recommendations presented herein.
\end{abstract}




\section{Acknowledgments}

Preparation of this Aging Management Guideline was performed by MDC-Ogden Environmental and Energy Services under the direction of the Department of Energy's Light Water Reactor Technology Center at Sandia National Laboratories, Advanced Nuclear Power Technology Department 6471. Funding of this guideline was provided by the Department of Energy's Light Water Reactor Safety and Technology Branch, NE-451. New York Power Authority's Indian Point-3 and James A. FitzPatrick plants acted as "hosts" and provided plant-specific data that helped to benchmark this report. Review and comments were provided by members of the Electric Power Research Institute (EPRI) Life Cycle Management (LCM) Subcommittee. Participation by personnel from the New York Power Authority is gratefully acknowledged, as is participation of the EPRI LCM Subcommittee reviewers. Cover photograph of the Perry Nuclear Power Plant provided courtesy of Cleveland Electric Illuminating Company. We also acknowledge the many survey respondents who provided data that helped to benchmark this guideline. 


\section{Contents}

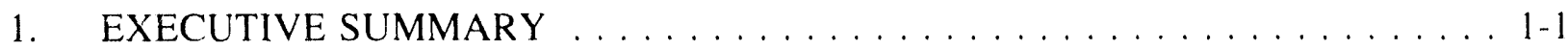

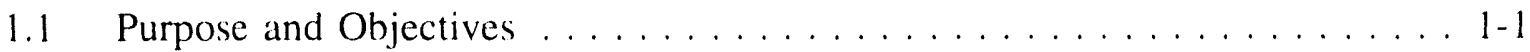

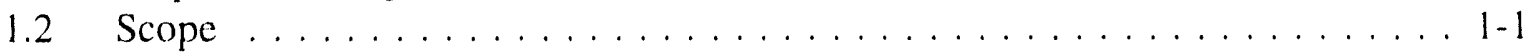

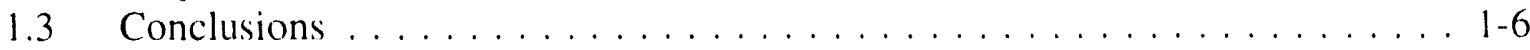

1.3.1 Aging Mechanism Conclusions . . . . . . . . . . . . . . . 1-6

1.3.2 Aging Management Program Guidelines . . . . . . . . . . . . . 1-9

1.4 References . . . . . . . . . . . . . . . . . . . . . 1-10

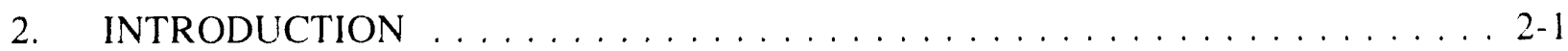

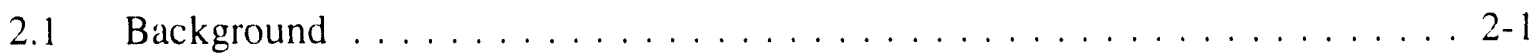

2.2 Purpose and Objectives . . . . . . . . . . . . . . . . . . 2-1

2.3 Contents of Aging Management Guideline . . . . . . . . . . . . . . . . 2-3

2.4 Generic License Renewal Requirements . . . . . . . . . . . . . . . . . . 2-6

2.5 Method Used to Define the Scope of Components Important to

License Renewal . . . . . . . . . . . . . . . . . . . . . . . . . . . . 2-8

2.6 Method Used to Define Aging Mechanisms Assessed in This Study . . . . . 2-8

2.7 References . . . . . . . . . . . . . . . . . . . . . . . . 2-9

3. EQUIPMENT/COMPONENTS EVALUATED: SCOPE . . . . . . . . . . . 3-1

3.1 Heat Exchanger Selection Methodology . . . . . . . . . . . . . 3-1

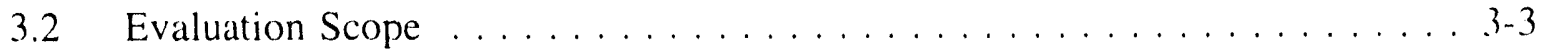

3.3 Component Boundaries . . . . . . . . . . . . . . . . . . 3-3

3.4 Description of Components Evaluated . . . . . . . . . . . . . . 3-4

3.4.1 Major Heat Exchanger Types . . . . . . . . . . . . . . . . 3-4

3.4 .2 Common Components . . . . . . . . . . . . . . . 3-6

3.4.3 Service Applications and Environments . . . . . . . . . . 3-8

3.4 .4 Differences in Design . . . . . . . . . . . . . . . . 3-12

3.4.5 Description of Predominant Types of Heat Exchangers . . . . . . 3-13

3.5 Design Requirements . . . . . . . . . . . . . . . . . . 3-22

3.5.1 Compliance with Standard Review Plan . . . . . . . . . . . . . . . 3-25

3.5.2 Application and Qualification of Non-Metallic Materials and Sacrificial Anodes . . . . . . . . . . . . . . . . 3-25

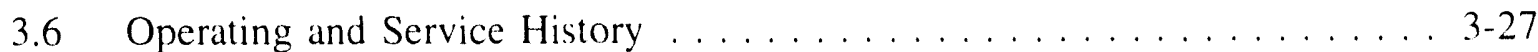

3.6.1 Licensee Event Report Evaluation . . . . . . . . . . . . . . . . 3-28

3.6.2 Nuclear Plant Reliability Data System Evaluation . . . . . . . . . . 3-32

3.7 References . . . . . . . . . . . . . . . . . . . 3-40 


\section{Contents (continued)}

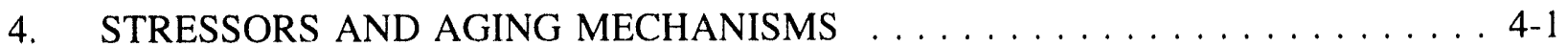

4.1 Determination of Stressors Acting on Heat Exchangers . . . . . . . . . . 4-1

4.1 .1 Mechanical Stressors . . . . . . . . . . . . . . . . . 4-2

4.1.2 Hydraulic Stressors . . . . . . . . . . . . . . . . 4-3

4.1 .3 Chemical Stressors . . . . . . . . . . . . . . . . . . . . . 4-4

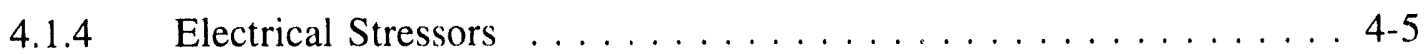

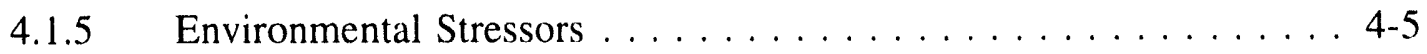

4.2 Description of Aging Mechanisms Acting on Heat Exchangers . . . . . . . 4-8

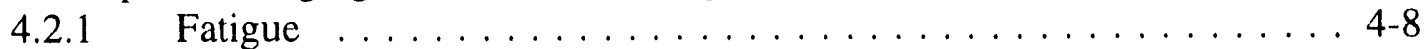

4.2 .2 Corrosion . . . . . . . . . . . . . . . . . . 4-9

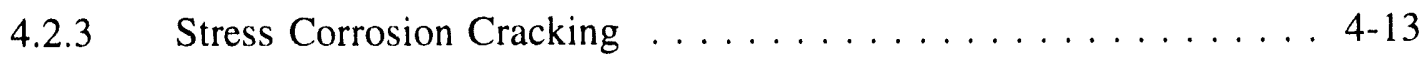

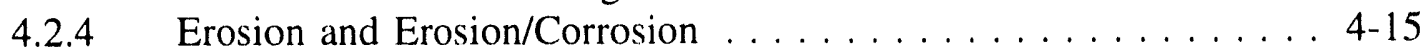

4.2 .5 Embrittlement ....................... 4-16

4.2 .6 Wear ......................... 4-17

4.2 .7 Stress Relaxation .................... . 4-18

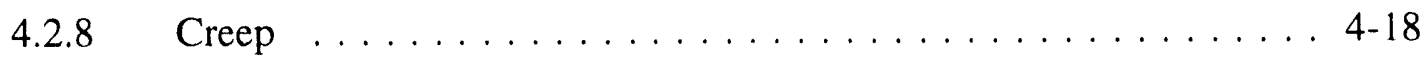

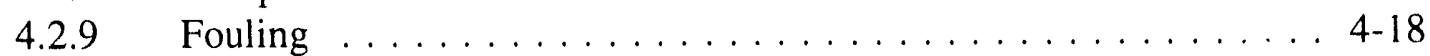

4.3 Evaluation of the Aging Mechanisms . . . . . . . . . . . . 4-21

4.3.1 Aging Mechanism Considerations that Apply to all Heat

Exchangers ......................... . . 4-21

4.3.2 Aging Mechanism Evaluations of Heat Exchanger

Components ....................... 4-41

4.3.3 Aging Mechanism Synergies and Dependencies . . . . . . . . . . . 4-73

4.3.4 Comparison of AMG with NPAR Results . . . . . . . . . . . . 4-74

4.4 References ........................ 4-75

5. EFFECTIVE MANAGEMENT OF AGING MECHANISMS . . . . . . . . . 5-1

5.1 Generic Elements of an Effective Aging Management Program . . . . . . . . 5-1

5.1 .1 Program is Documented . . . . . . . . . . . . . . . 5-2

5.1.2 Program Implementing Procedures Approved by Operations

Review Committee and Program Inıplemented Via

Administrative Procedures ... . . . . . . . . . . . . . 5-2

5.1.3 Component's Required Functions Properly Addressed . . . . . . . . . . 5-2

5.1.4 Age-Related Degradation Effects Properly Addressed . . . . . . . . . 5-3

5.1.5 Acceptance Criteria Established to Determine Need for Corrective Action, Corrective Actions Specified, and Timely Action Taken .................. . . . 5-3

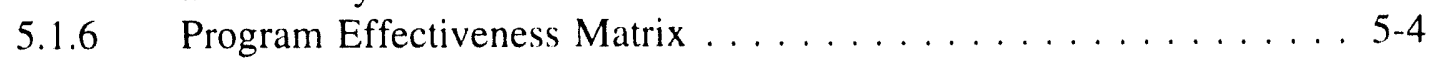




\section{Contents (continued)}

5.2 Conventional Effective Programs Commonly Used in the Industry . . . . . 5 5-5

5.2.1 ASME Section XI Inservice Inspection Program . . . . . . . . . 5-5

5.2 .2 ASME Operation and Maintenance Code . . . . . . . . . . . 5-9

5.2.3 Preventive Maintenance Program . . . . . . . . . . . . . 5-9

5.2.4 Microbiologically Influenced Corrosion (MIC) Control

Program . . . . . . . . . . . . . . . . . . . . 5-26

5.3 Non-Conventional Effective Programs Commonly Used in the Industry . . 5-28

5.3.1 Heat Exchanger Lay-Up Program . . . . . . . . . . . . . 5-28

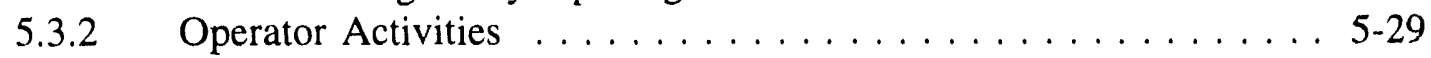

5.3 .3 Coatings Survey Program .................. 5-30

5.3 .4 Operating/Industry Experience Program . . . . . . . . . . 5-30

5.3.5 Spare Parts Shelf-Life Program . . . . . . . . . . . . . 5-30

5.3.6 Receipt Inspection . . . . . . . . . . . . . . . . . 5-31

5.4 Programs/Techniques Applied to Heat Exchangers $\ldots \ldots \ldots \ldots \ldots \ldots$. . . . . . . .

5.4.1 Primary Water System Heat Exchangers $\ldots \ldots \ldots \ldots \ldots \ldots$ 5-32

5.4.2 Treated Water System Heat Exchangers . . . . . . . . . . . . . 5-45

5.4.3 Closed Cooling Water System Heat Exchangers . . . . . . . . 5-61

5.4 .4 Lubricating Oil System Heat Exchangers . . . . . . . . . . . 5-72

5.4.5 Raw Water System Heat Exchangers . . . . . . . . . . . . 5-80

5.4.6 Drywell/Reactor Building/Containment Atmospheric System

Heat Exchangers . . . . . . . . . . . . . . . . . . . . . . . . 5-99

5.5 References ........................... 5-106

6. OTHER AGING MANAGEMENT CONSIDERATIONS $\ldots \ldots \ldots \ldots \ldots \ldots$ 6-1

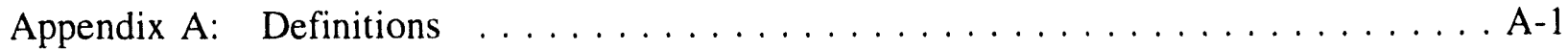

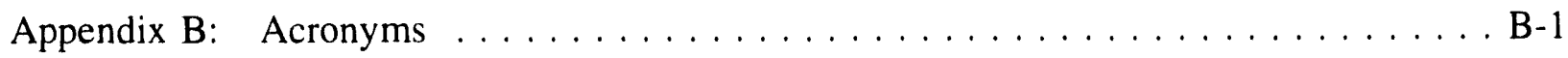




\section{Figures}

3-1 Shell and Tube Heat Exchanger with Floating Head . . . . . . . . . . . . 3-3

3-2 Shell and Tube Heat Exchanger with Segmental Baffles . . . . . . . . . . . . 3-4

3-3 Common Heat Exchanger Baffle Arrangement . . . . . . . . . . . . . . 3-5

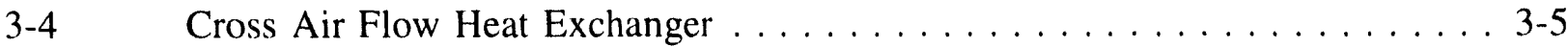

3-5 Heat Exchanger Failures and Aging Causes . . . . . . . . . . . . . 3-30

3-6 BWR Heat Exchanger Aging Failures LER Database 1980-1992 . . . . . . 3-31

3-7 PWR Heat Exchanger Aging Failures LER Database 1980-1992 . . . . . . . 3-31

3-8 Heat Exchanger Aging Failures NPRDS Database . . . . . . . . . . . . 3-33

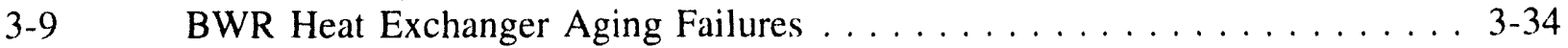

3-10 PWR Heat Exchanger Aging Failures . . . . . . . . . . . . . . . . . 3-34

3-11 Heat Exchanger Type Failures BWR Plants . . . . . . . . . . . . . 3-35

3-12 Heat Exchanger Type Failures PWR Plants . . . . . . . . . . . . . . 3-36

3-13 Heat Exchanger Failures and Aging Causes NPRDS Data . . . . . . . . 3-36

3-14 NPRDS Heat Exchanger Failures Vs. Service Time . . . . . . . . . . . . . . 3-39

4-1 Corrosion Potential Vs. Percent IGSCC for Sensitized Type 304

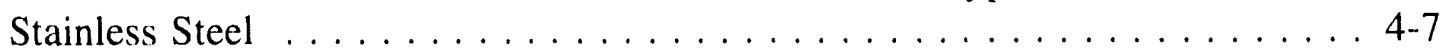

4-2 Interrelation Between Oxygen, Temperature Combinations that Can

Trigger IGSCC . . . . . . . . . . . . . . . . . . . . . . 4-7

4-3 Common Heat Exchanger Tube Degradation $\ldots \ldots \ldots \ldots \ldots \ldots \ldots$. . . . . . . . . .

\section{Tables}

1-1 Process and Cooling Fluid Media BWR Heat Exchangers . . . . . . . . . . . 1-2

1-2 Process and Cooling Fluid Media PWR Heat Exchangers . . . . . . . . . . 1-3

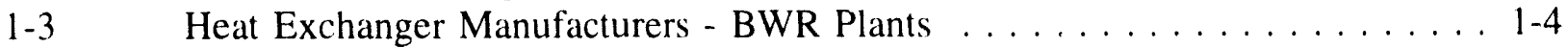

1-4 Heat Exchanger Manufacturers - PWR Plants . . . . . . . . . . . . . 1-5

1-5 Heat Exchanger Components and Aging Mechanism Significance Summary . . 1-7

1-6 Heat Exchanger Aging Management Programs/Techniques . . . . . . . . . . . 1-9

2-1 Heat Exchangers in Scope of $\mathrm{AMG} \ldots \ldots \ldots \ldots \ldots \ldots \ldots$

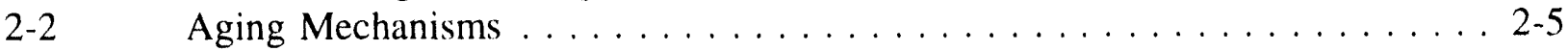

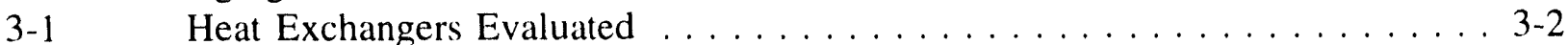

3-2 Heat Exchanger Component Groups and Subcomponents . . . . . . . . . . . 3-6

3-3 Typical Heat Exchanger Materials . . . . . . . . . . . . . . . 3-7

3-4 Heat Exchanger Subcomponent Environments . . . . . . . . . . . . . . 3-8

3-5 Process and Cooling Fluid Media BWR Heat Exchangers . . . . . . . . . . . 3-9

3-6 Process and Cooling Fluid Media PWR Heat Exchangers . . . . . . . . . . . 3-10

3-7 Heat Exchanger Application Summary PWR Heat Exchangers . . . . . . . . . 3-14

3-8 Heat Exchanger Application Summary BWR Heat Exchangers . . . . . . . 3-16

3-9 Heat Exchanger Manufacturers - PWR Plants . . . . . . . . . . . . . 3-18

3-10 Heat Exchanger Manufacturers — BWR Plants . . . . . . . . . . . . . . 3-19 
Tables (continued)

3-11 Non-Metallic Material Allowable Temperature and Radiation

Exposures . . . . . . . . . . . . . . . . . . . . . . 3-26

3-12 Non-Metallic Material Radiation Data . . . . . . . . . . . . . . . . . . 3-27

3-13 List of NRC Information Notices, Bulletins, Circulars, and Generic

Letters Related to Heat Exchanger Degradation . . . . . . . . . . . . . . . 3-28

3-14 Heat Exchanger Subcomponent Failures Due to Aging - LER Database . . . 3-32

3-15 Heat Exchanger Subcomponent Failures Due to Aging - NPRDS

Database 1974-1992 . . . . . . . . . . . . . . . . . . . . . . . 3-37

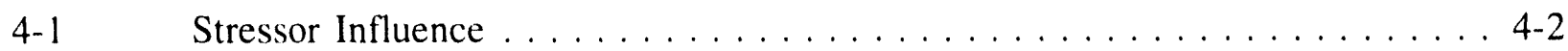

4-2 Galvanic Series . . . . . . . . . . . . . . . . . . . 4-4

4-3 Significance of Aging Mechanisms for Primary/Water System

Heat Exchangers . . . . . . . . . . . . . . . . . . . . . . 4-22

4-4 Significance of Aging Mechanisms for Treated/Water System

Heat Exchangers ... . . . . . . . . . . . . . . . . . . 4-22

4-5 Significance of Aging Mechanisms for Closed Cooling Water System

Heat Exchangers ... . . . . . . . . . . . . . . . . . . . . 4 4-23

4-6 Significance of Aging Mechanisms for Lubricating Oil System

Heat Exchangers . . . . . . . . . . . . . . . . . . . . . . . . . 4-23

4-7 Significance of Aging Mechanisms for Raw Water System Heat

Exchangers . . . . . . . . . . . . . . . . . . . . . 4-24

4-8 Significance of Aging Mechanisms for Drywell/Reactor Building/

Containment Atmospheric Heat Exchangers . . . . . . . . . . . . . . . . . . . 4 4-24

4-9 Fluid Temperature Conditions - BWR Heat Exchangers . . . . . . . . . . . . 4-27

4-10 Fluid Temperature Conditions - PWR Heat Exchangers . . . . . . . . . . 4 4-28

5-1 Effective Program Criteria and Assessment Matrix . . . . . . . . . . . . . 5-4

5-2 Effective Programs/Techniques for Primary Water System Heat

5-3 Effective Programs/Techniques for Treated Water System Heat

Exchangers . . . . . . . . . . . . . . . . . . . . . . 5-48

5-4 Effective Programs/Techniques for Closed Cooling Water System .

5-5 Effective Programs/Techniques for Lubricating Oil System Heat

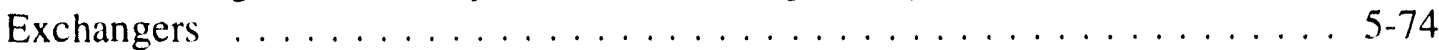

5-6 Effective Programs/Techniques for Raw Water System Heat Exchangers . . . 5-83

5-7 Effective Programs/Techniques for Drywell/Reactor Building/

Containment Atmospheric System Heat Exchangers . . . . . . . . . . . . 5-101 


\section{AGING MANAGEMENT GUIDELINE FOR HEAT EXCHANGERS}

\section{EXECUTIVE SUMMARY}

Continued operation of nuclear power plants for periods that extend beyond their original 40-year license period is a desirable option for many U.S. utilities. U.S. Nuclear Regulatory Commission (NRC) approval of operating license renewals is necessary before continued operation becomes a reality. Effective aging management for plant components is important to reliability and safety, regardless of current plant age or extended life expectations. However, the NRC requires that aging evaluations be performed and the existence of appropriate aging management programs be demonstrated for components considered important to license renewal before granting approval for operation beyond 40 years. Both the NRC and the utility want assurance that high reliability for plant components will be maintained during both the current license term and throughout the extended operating period.

\subsection{Purpose and Objectives}

The purpose of this aging management guideline (AMG) is to provide guidance for effective aging management of a selected group of heat exchangers which are important to safe and reliable nuclear power plant operation. The heat exchanger applications studied are those found in both Boiling Water Reactor (BWR) and Pressurized Water Reactor (PWR) facilities. The primary target audience for this AMG are plant engineering, operations, and maintenance personnel, although it will also be of interest to those involved with nuclear plant life extension programs. The AMG is presented in a manner which allows personnel responsible for heat exchanger performance analysis and maintenance to compare their plant-specific heat exchanger aging mechanisms (expected or already experienced) and aging management program activities to the more generic results and recommendations presented in this AMG.

\subsection{Scope}

The nuclear plant heat exchanger applications included in this AMG are listed in Tables 1-1 and 1-2. This listing includes all major heat exchangers which have been identified as important to license renewal based on the NRC criteria provided in 10 CFR 54 [1.1], with the exception of the PWR steam generators, which have been studied extensively in previously published reports $[1.2,1.3]$. Note that the Maintenance Rule 10 CFR 50.65 scope is almost the same as the License Renewal Rule 10 CFR 54.21 scope.

Tables 1-3 and 1-4 list the heat exchanger manufacturers for PWR and BWR plants respectively. This information was obtained from the Nuclear Plant Reliability Data System (NPRDS) database and questionnaire responses from several utilities. The aging evaluation (Section 4) and effective program evaluation (Section 5) encompass all of these heat exchanger manufacturers. Utility personnel should verify that their heat exchanger type and corresponding manufacturer are within the scope of this AMG prior to applying the results and recommendations. 
Table 1-1. Process and Cooling Fluid Media BWR Heat Exchangers

\begin{tabular}{lll}
\multicolumn{1}{c}{ BWR Heat Exchanger } & \multicolumn{1}{c}{ Tube Side Fluid } & \multicolumn{1}{c}{ Shell Side Fluid } \\
\hline $\begin{array}{l}\text { Component Cooling Water (Note 1) } \\
\text { Drywell Coolers }\end{array}$ & Raw Water & Closed Cooling Water \\
Emergency Core Cooling System Room Coolers & Closed Cooling Water & Drywell Atmosphere \\
Emergency Diesel Generator Jacket Water & Raw Water & $\begin{array}{l}\text { Reactor Building } \\
\text { Atmosphere }\end{array}$ \\
Emergency Diesel Generator Lubrication Oil & Ratw Water & Lubrication Oil \\
High Pressure Coolant Injection Gland Seal Condenser & Treated Water & Primary Water \\
High Pressure Coolant Injection Lubrication Oil & Treated Water & Lubrication Oil \\
Miscellaneous Oil Coolers & Closed Cooling Water & Lubrication Oil \\
Reactor Core Isolation Cooling Lubrication Oil & Treated Water & Lubrication Oil \\
Reactor Water Cleanup Non-Regenerative & Primary Water & Closed Cooling Water \\
Reactor Water Cleanup Regenerative & Primary Water & Primary Water \\
Residual Heat Removal (Note 2) & Raw Water & Treated Water \\
Spent Fuel Pool & Treated Water & Closed Cooling Water
\end{tabular}

Notes:

1. Includes various system names, such as component cooling water, emergency equipment cooling water, essential equipment cooling water, reactor building closed cooling water, auxiliary building closed cooling water and emergency service water.

2. Includes various system names, such as decay heat removal, low pressure coolant injection, shutdown cooling, and containment cooling.

The evaluations in this AMG include the heat exchanger tubes/coils, tube sheets, partitions/baffles, shell/nozzles, internals, waterboxes/channel heads/end bells/flanges, divider plates, floating heads, fasteners, and support assemblies.

The strategy for preparing this AMG includes (1) identifying the heat exchanger types, major heat exchanger subcomponents, and typical operating conditions, and (2) collecting and evaluating heat exchanger operating/maintenance history information, identifying the stressors acting on these heat exchangers, and determining the significance of heat exchanger aging mechanisms. After completing these tasks and reviewing currently utilized aging management practices, guidelines are presented for effective management of these heat exchangers. 
Table 1-2. Process and Cooling Fluid Media PWR Heat Exchangers

\begin{tabular}{lll}
\multicolumn{1}{c}{ PWR Heat Exchanger } & \multicolumn{1}{c}{ Tube Side Fluid } & \multicolumn{1}{c}{ Shell Side Fluid } \\
\hline $\begin{array}{l}\text { Chemical and Volume Control System Excess } \\
\text { Letdown }\end{array}$ & Primary Water & Closed Cooling Water \\
Chemical and Volume Control Letdown & Primary Water & Closed Cooling Water \\
Chemical and Volume Control Regenerative & Primary Water & Primary Water \\
Chemical and Volume Control System Seal Water & Primary Water & Closed Cooling Water \\
Component Cooling Water (Note 1) & Raw Water & Closed Cooling Water \\
Containment Air Coolers & Raw Water & Containment Atmosphere \\
Emergency Core Cooling System Room Coolers & Raw Water & Atmosphere \\
Emergency Diesel Generator Jacket Water & Raw Water & Closed Cooling Water \\
Emergency Diesel Generator Lubrication Oil & Raw Water & Lubrication Oil \\
Miscellaneous Oil Coolers & Closed Cooling Water & Lubrication Oil \\
Residual Heat Removal (Note 2) & Primary Water & Closed Cooling Water \\
Spent Fuel Pool & Treated Water & Closed Cooling Water
\end{tabular}

Notes:

1. Includes various system names, such as component cooling water, emergency equipment cooling water, essential equipment cooling water, reactor building closed cooling water, auxiliary building closed cooling water and emergency service water.

2. Includes various system names such as low pressure safety injection, shutdown cooling, and decay heat removal.

The input for development of this AMG includes design data, operating/maintenance history (including degradation findings and failure incidents), and current inspection, testing, and maintenance program activities. The information is obtained from a variety of sources including NRC publications, computerized industry databases, heat exchanger manufacturer literature, individual nuclear plant records, and aging management reports and papers prepared by the Electric Power Research Institute (EPRI), the U.S. Department of Energy (DOE), and engineering consultants. 
AGING MANAGEMENT GUIDELINE FOR HEAT EXCHANGERS

Table 1-3. Heat Exchanger Manufacturers - BWR Plants

\begin{tabular}{|c|c|c|c|c|c|c|c|c|c|}
\hline $\begin{array}{l}\text { Component } \\
\text { Cooling Water }\end{array}$ & $\begin{array}{l}\text { Drywell } \\
\text { Cooling }\end{array}$ & $\begin{array}{l}\text { Emergency } \\
\text { Core Cooling } \\
\text { Room Coolers }\end{array}$ & $\begin{array}{c}\text { Emergency } \\
\text { Diesel } \\
\text { Generator } \\
\text { Jacket Water } \\
\text { and Lube Oil } \\
\text { Cooling }\end{array}$ & $\begin{array}{c}\text { High } \\
\text { Pressure } \\
\text { Coolant } \\
\text { Injection } \\
\text { Gland Seal } \\
\text { Condenser }\end{array}$ & $\begin{array}{c}\text { High Pressure } \\
\text { Coolant } \\
\text { Injection } \\
\text { Lube Oil } \\
\text { Cooler }\end{array}$ & $\begin{array}{l}\text { Reactor Core } \\
\text { Isolation } \\
\text { Cooling Lube } \\
\text { Oil Cooling }\end{array}$ & $\begin{array}{l}\text { Reactor Water } \\
\text { Cleanup } \\
\text { Regenerative } \\
\text { and Non- } \\
\text { Regenerative }\end{array}$ & $\begin{array}{l}\text { Residual } \\
\text { Heat } \\
\text { Removal }\end{array}$ & $\begin{array}{c}\text { Spent Fuel } \\
\text { Pool Cooling }\end{array}$ \\
\hline Oat. Joseph & CTI Nuclear & Carrier & $\begin{array}{l}\text { Young } \\
\text { Radiator }\end{array}$ & Graham & $\begin{array}{l}\text { American } \\
\text { Standard. Inc. }\end{array}$ & $\begin{array}{l}\text { American } \\
\text { Standard, Inc. }\end{array}$ & $\begin{array}{l}\text { American } \\
\text { Standard. Inc. }\end{array}$ & $\begin{array}{l}\text { Southwestern } \\
\text { Engineering }\end{array}$ & $\begin{array}{l}\text { Industrial } \\
\text { Process } \\
\text { Engineering }\end{array}$ \\
\hline $\begin{array}{l}\text { American } \\
\text { Industrial } \\
\text { Technologies }\end{array}$ & $\begin{array}{l}\text { American } \\
\text { Standard. Inc. }\end{array}$ & $\begin{array}{l}\text { American } \\
\text { Standard. Inc. }\end{array}$ & $\begin{array}{l}\text { American } \\
\text { Standard, Inc. }\end{array}$ & & & & $\begin{array}{l}\text { Heat Transfer } \\
\text { Products }\end{array}$ & Perfex & \\
\hline Yuba Heat & Carrier & Perfex & Electro-Motive/ & & & & & MLW Ind. & \\
\hline Transfer & Aerofin & Ellis and Watts & General Motors & & & & . & Borg-Warner & \\
\hline $\begin{array}{l}\text { American } \\
\text { Standard. Inc. }\end{array}$ & & & $\begin{array}{l}\text { Allo Power. } \\
\text { Inc. }\end{array}$ & & & & & $\begin{array}{l}\text { Berlin } \\
\text { Chapman }\end{array}$ & \\
\hline Struthers Wells & & & $\begin{array}{l}\text { Handy Harman } \\
\text { Corp. }\end{array}$ & & & & & $\begin{array}{l}\text { Struthers } \\
\text { Wells }\end{array}$ & \\
\hline $\begin{array}{l}\text { McQuay } \\
\text { Engineers and } \\
\text { Fabricators }\end{array}$ & & & $\begin{array}{l}\text { Stewart \& } \\
\text { Stevenson } \\
\text { Services }\end{array}$ & & & & & $\begin{array}{l}\text { Worthington/ } \\
\text { McGraw- } \\
\text { Edison }\end{array}$ & \\
\hline Whitelock & & & $\begin{array}{l}\text { Fairbanks } \\
\text { Morse Engine }\end{array}$ & & & & & Oat. Joseph & \\
\hline Perfex & & & Westinghouse & & & & & & \\
\hline Foster Wheeler & & & & & & & & & \\
\hline $\begin{array}{l}\text { Trane } \\
\text { Industrial Process } \\
\text { Engineering }\end{array}$ & & & & & & & & & \\
\hline
\end{tabular}


AGING MANAGEMENT GUIDELINE FOR HEAT EXCHANGERS

\section{Table 1-4. Heat Exchanger Manufacturers - PWR Plants}

\begin{tabular}{|c|c|c|c|c|c|c|c|c|}
\hline $\begin{array}{l}\text { Chemical and } \\
\text { Volume Control } \\
\text { Letdown and } \\
\text { Excess Letdown }\end{array}$ & $\begin{array}{l}\text { Chemical and } \\
\text { Volume Control } \\
\text { Regenerative }\end{array}$ & $\begin{array}{l}\text { Chemical and } \\
\text { Volume Control } \\
\text { Seal Water }\end{array}$ & $\begin{array}{l}\text { Component } \\
\text { Cooling Water }\end{array}$ & $\begin{array}{l}\text { Containment } \\
\text { Air Cooling }\end{array}$ & $\begin{array}{c}\text { Emergency } \\
\text { Core Cooling } \\
\text { Room Coolers }\end{array}$ & $\begin{array}{c}\text { Emergency } \\
\text { Diesel Generator } \\
\text { Jacket Water } \\
\text { and Lube Oil } \\
\text { Cooling }\end{array}$ & $\begin{array}{c}\text { Residual } \\
\text { Heat Removal }\end{array}$ & $\begin{array}{c}\text { Spent } \\
\text { Fuel Pool }\end{array}$ \\
\hline Graham & Sentry Equipment & Atlas Industrial & Struthers Wells & $\begin{array}{l}\text { American Air } \\
\text { Filter }\end{array}$ & Carrier & $\begin{array}{l}\text { American } \\
\text { Standard, Inc. }\end{array}$ & $\begin{array}{l}\text { Dresser } \\
\text { Industrial }\end{array}$ & Oat, Joseph \\
\hline $\begin{array}{l}\text { Atlas Industrial } \\
\text { MLW }\end{array}$ & $\begin{array}{l}\text { Westinghouse/ } \\
\text { Hagan }\end{array}$ & $\begin{array}{l}\text { Westinghouse/ } \\
\text { Hagan }\end{array}$ & $\begin{array}{l}\text { Delta Southern } \\
\text { Yuba Heat }\end{array}$ & $\begin{array}{l}\text { Westinghouse/ } \\
\text { Hagan }\end{array}$ & $\begin{array}{l}\text { American } \\
\text { Standard, Inc. }\end{array}$ & Basco & $\begin{array}{l}\text { Atlas } \\
\text { Industrial }\end{array}$ & $\begin{array}{l}\text { Atlas } \\
\text { Industrial }\end{array}$ \\
\hline Oat, Joseph & $\begin{array}{l}\text { Southwestem } \\
\text { Engineering }\end{array}$ & Basco & $\begin{array}{l}\text { Transfer } \\
\text { American }\end{array}$ & Carrier & $\begin{array}{l}\text { Perfex } \\
\text { Ellis and Watts }\end{array}$ & $\begin{array}{l}\text { Perfex } \\
\text { Young Radiator }\end{array}$ & $\begin{array}{l}\text { Yuba Heat } \\
\text { Transfer }\end{array}$ & \\
\hline $\begin{array}{l}\text { Westinghouse/ } \\
\text { Hagan }\end{array}$ & & & Standard, Inc. & Joy & & Thermxchanger & Engineers and & \\
\hline \multirow{9}{*}{ Sentry Equipment } & & & Graham & $\begin{array}{l}\text { Marlo Coil } \\
\text { Nuclear Cooling }\end{array}$ & & Graham & & \\
\hline & & & $\begin{array}{l}\text { Engineers and } \\
\text { Fabricators }\end{array}$ & & & EC Cooley & & \\
\hline & & & Foster Wheeler & & & $\begin{array}{l}\text { Fairbanks Morse } \\
\text { Engine }\end{array}$ & & \\
\hline & & & $\begin{array}{l}\text { Worthington/ } \\
\text { McGraw-Edison }\end{array}$ & & & ITT Standard & & \\
\hline & & & Marlow Industries & & & $\begin{array}{l}\text { Electro-Motive/ } \\
\text { General Motors }\end{array}$ & & \\
\hline & & & Atlas Industrial & & & Westinghouse & & \\
\hline & & & $\begin{array}{l}\text { Vogt, Henry } \\
\text { Machine }\end{array}$ & & & & & \\
\hline & & & $\begin{array}{l}\text { Westinghouse/ } \\
\text { Hagan }\end{array}$ & & & & & \\
\hline & & & Oat, Joseph & & & & & \\
\hline
\end{tabular}




\subsection{Conclusions}

This AMG evaluates all aging mechanisms for the heat exchanger applications listed in Tables 1-1 and 1-2. Section 4 examines aging mechanisms to determine which are nonsignificant, and which are significant. Section 5 examines aging management programs/ techniques to determine which are effective for detecting and/or mitigating the significant aging mechanisms. The heat exchanger applications shown in Tables $1-1$ and 1-2 involve several different fluid types, heat exchanger types, and operating modes. Unique differences exist between plants with respect to heat exchanger type, materials, and operating parameters for similar service applications. Therefore, in order to contend with this diversity, some consolidation and simplification was necessary to prepare an AMG that can be utilized by each individual plant.

Common characteristics of heat exchanger designs and service applications are examined to establish groupings for aging mechanism and aging management program/technique evaluations.

The primary characteristic for grouping selected heat exchangers is the process and cooling fluid. The heat exchanger fluid categories are listed with the heat exchanger applications in Tables 1-1 and 1-2. Operating mode (standby versus continuous operation) is used as the second method for grouping selected heat exchanger. In addition, all heat exchangers were divided into logical subassembly groupings (tubes, tube sheets, shells, etc.). These subassembly groupings are maintained throughout the AMG.

It is not possible for this AMG to cover all plant-unique situations. Therefore, it is necessary to identify a generic standard that is representative of a majority of the existing plant applications with regard to heat exchanger design, materials, operating parameters, and safety function classification. The determination of (1) significance/non-significance for specific aging mechanisms, (2) aging mechanism/subcomponent combinations, and (3) applicability of aging management programs/techniques is, therefore, based on this generic standard. These qualifications or conditions are presented in an if/then format (for example; if stainless steel materials are used, then general corrosion is non-significant). With these qualifications, plant personnel can uniquely determine how the AMG results are applicable to their specific application.

\subsubsection{Aging Mechanism Conclusions}

The heat exchanger aging mechanisms evaluated in this report are listed in Table 2-1. Table 1-5 summarizes the significance of the aging mechanisms with respect to heat exchanger components. Table 1-5 identifies aging mechanisms which are effectively managed by current plant programs. 
AGING MANAGEMENT GUIDELINE FOR HEAT EXCHANGERS

\begin{tabular}{|c|c|c|c|c|c|c|c|c|c|c|c|c|c|c|c|c|}
\hline \multirow[b]{2}{*}{ Subcomponents } & \multicolumn{2}{|c|}{ Fatigue } & \multicolumn{4}{|c|}{ Corrosion } & \multicolumn{3}{|c|}{ Stress Corrosion Cracking } & \multirow[b]{2}{*}{ Erosion } & \multicolumn{2}{|c|}{ Embrittlement } & \multirow[b]{2}{*}{ Wear } & \multirow{2}{*}{$\begin{array}{c}\text { Stress } \\
\text { Relax- } \\
\text { ation } \\
\end{array}$} & \multirow[b]{2}{*}{ Creep } & \multirow[b]{2}{*}{ Fouling } \\
\hline & Thermal & Mechanical & Gen & Galv & Pitting & $\mathrm{MIC}^{1}$ & IGSCC $^{2}$ & IASCC $^{3}$ & TGSCC $^{4}$ & & Thermal & Neutron & & & & \\
\hline Tubes/Coils & -- & $\mathrm{x}$ & $\mathrm{x}$ & $\mathrm{x}$ & $\mathrm{X}$ & $\mathrm{X}$ & $\mathrm{x}$ & -- & -- & $\mathrm{x}$ & -- & -- & $\mathrm{x}$ & - & $-\cdot$ & $\mathrm{x}$ \\
\hline Tube Sheets & -- & $\mathrm{x}$ & $\mathrm{x}$ & $\mathrm{x}$ & $\mathrm{x}$ & $\mathrm{X}$ & $\mathrm{x}$ & -- & $\mathrm{x}$ & $\mathrm{x}$ & -- & -- & $\mathrm{x}$ & -- &.- & $\mathrm{X}$ \\
\hline $\begin{array}{l}\text { Shell/Nozzles } \\
\text { Internals }\end{array}$ & -- & $\mathrm{X}$ & $\mathrm{x}$ & $\mathrm{x}$ & - & $\mathrm{x}$ & - & -- & -- & $\mathrm{x}$ & - & -. & - & -- & -- & $\mathrm{x}$ \\
\hline $\begin{array}{l}\text { Water Box/ } \\
\text { Channel Head/ } \\
\text { Divider Plate }\end{array}$ & -- & $\mathrm{x}$ & $\mathrm{X}$ & $\mathrm{x}$ & $\mathrm{x}$ & $\mathrm{x}$ & $\mathrm{x}$ & -. & -- & $\mathrm{X}$ & -- & -- & -- & -- & - & $\mathrm{X}$ \\
\hline $\begin{array}{l}\text { Pressure } \\
\text { Boundary } \\
\text { Fasteners/ } \\
\text { Support } \\
\text { Assembly }\end{array}$ & -- & -- & $\mathrm{X}$ & -. & $x$ & -- & -- & -- & -- & -- & -. & -. & -- & $x$ & $\cdot \cdot$ & -- \\
\hline
\end{tabular}

MIC Microbiological influenced corrosion

2 IGSCC Intergranular stress corrosion cracking

IASCC Irradiation assisted stress corrosion cracking

4 TGSCC Transgranular stress corrosion cracking

-- Aging mechanism is not significant for all heat exchanger subcomponent applications.

$\mathrm{X}$ Aging mechanism is significant for some of the heat exchanger subcomponent applications (see Section 4 and Tables 4-4 through 4-9) and current plant programs exist to effec ively manage component aging (see Section 5 and Tables 5-4 through 5-9). 
The mechanisms determined to be non-significant for all applications are listed below:

- Thermal Embrittlement (Section 4.3.1.1)

- Creep (Section 4.3.1.1)

- Thermal Fatigue (Section 4.3.1.3)

- Irradiation Assisted Stress Corrosion Cracking (Section 4.3.1.2)

- Neutron Embrittlement (Section 4.3.1.2)

Since the heat exchanger applications covered by this AMG involve relatively low temperature fluids and low radiation level environments, very few conditions or qualifications were necessary to establish these aging mechanisms as not significant.

The mechanisms determined to be significant for some applications are listed below:

- Stress Relaxation (Section 4.3.1.1)

- Mechanical Fatigue (Section 4.3.1.4)

- Corrosion (Section 4.3.1.5)

- Stress Corrosion Cracking (Section 4.3.1.6)

- Erosion and Erosion/Corrosion (Section 4.3.1.7)

- Wear (Section 4.3.1.8)

- Fouling (Section 4.3.1.9)

These mechanisms are examined in Section 4.3.2 for each of the five subcomponent groupings listed below:

- Tubes/Coils

- Tube Sheets

- Shell/Nozzles/Internals

- Waterbox/Channel Head/Divider Plate

- Pressure Boundary Fasteners/Support Assembly

The examinations in Section 4.3.2 determined that several combinations of these aging mechanisms and heat exchanger subassembly components are significant and, therefore, require effective aging management programs/techniques. The conclusions for these aging mechanisms are summarized in Tables 4-4 through 4-9. If/then criteria, located in the text, provide the conditions and qualifications for these significance determinations.

The aging mechanisms are evaluated taking into consideration the effects of each of the following five fluid applications plus atmospheric applications.

- Primary Water

- Treated Water

- Closed Cooling Water

- Lubricating Oil

- Raw Water 
The generic examinations in Section 4.3.1 determined that selected combinations of heat exchanger component materials and fluid applications were susceptible to corrosion (general, galvanic, or microbiologically influenced), stress corrosion cracking (IGSCC and TGSCC), erosion and erosion/corrosion, and fouling.

The fluid service examinations in Section 4.3.2 were able to establish non-significance for various types of corrosion and stress corrosion cracking, erosion and erosion/corrosion, and fouling associated with various heat exchanger subcomponents based on metallurgy and design characteristics. Examples include the use of corrosion resistant stainless steel materials, relatively large surface areas for the more inodic wetted parts, and the washing away of microbial growth with high fluid velocities. The evaluation conclusions for these aging mechanisms are summarized in Tables 4-4 through 4-9. If/then criteria located in the text provide the conditions and qualifications for significance determinations.

The aging management programs/techniques that effectively manage the significant aging mechanism/heat exchanger subcomponent combinations for each fluid application are discussed in Section 5.

\subsubsection{Aging Management Program Guidelines}

The aging management programs/techniques presented in this AMG are listed in Table 1-6. The conventional programs commonly used are currently implemented at nuclear facilities. For some of the heat exchangers in the scope of this AMG, surveillance tests may be

\section{Table 1-6. Heat Exchanger Aging Management Programs/Techniques}

Cenventional Programs

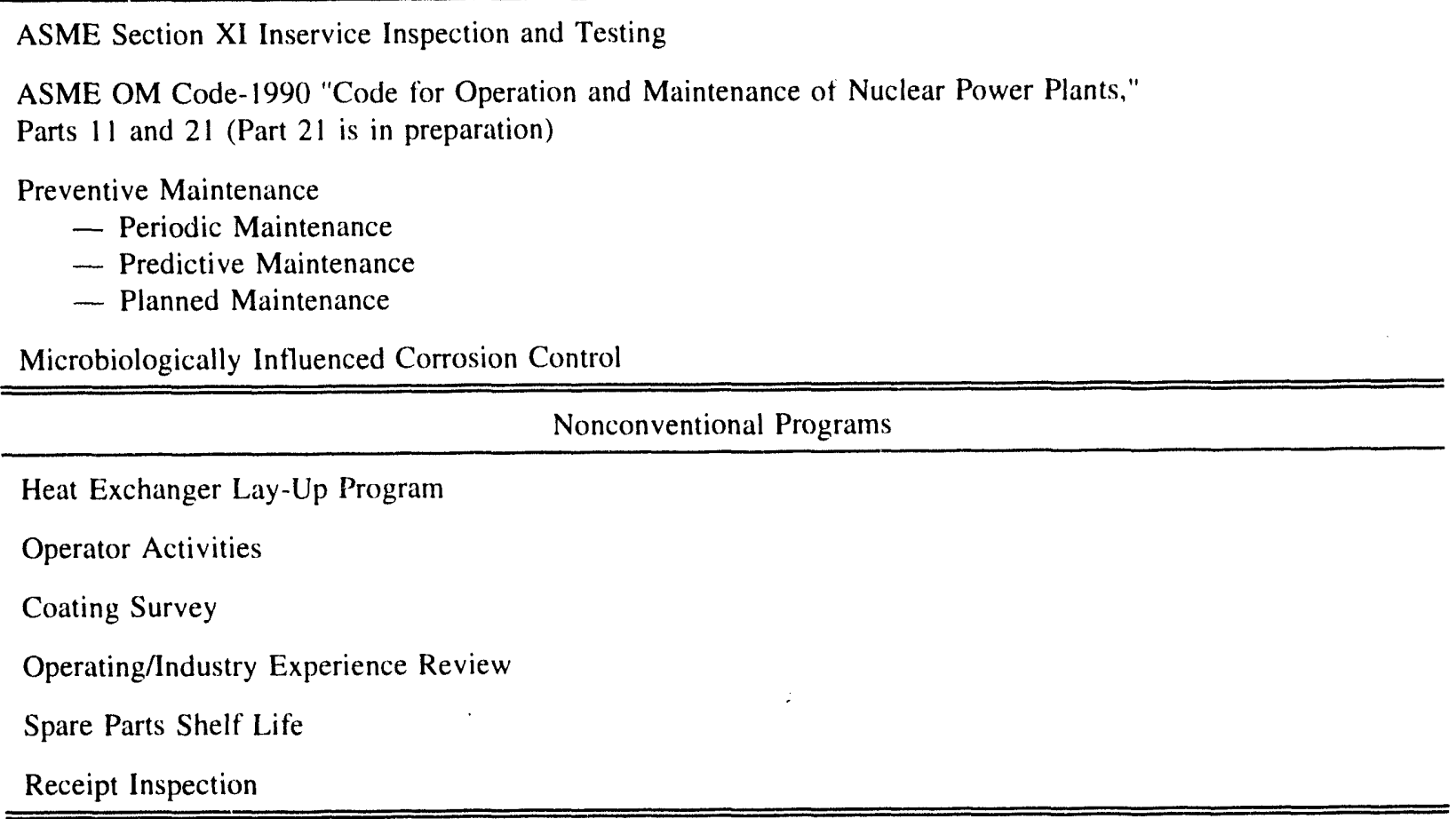


performed in accordance with plant specific Technical Specifications. Also, NRC required efficiency tests (for example, Reference 1.4) are performed on some of the heat exchangers. For purposes of this AMG all heat exchanger testing regardless of origin is described in the Preventive Maintenance Program. The nonconventional programs commonly used are also currently implemented at most nuclear plants, but in some cases may not be formalized with written procedures. The requirements for effective aging management programs are listed below:

a. The program must identify and mitigate age-related degradation unique to license renewal.

b. The program must contain acceptance criteria against which the need for corrective action can be evaluated and assure timely corrective action when the acceptance criteria are not met.

c. The program must be implemented by the facility operating procedures and reviewed by the onsite review committee.

The aging management programs/techniques are described generically in Section 5.2 (Conventional Programs) and Section 5.3 (Nonconventional Programs). The relationship between these aging management programs/techniques and the significant aging mechanisms determined in Section 4 is examined for heat exchanger subcomponents in each fluid application category. The results of this examination are shown in Tables 5-4 through 5-9. These tables relate the aging management programs/techniques to the significant aging mechanism for the individual heat exchanger subcomponents. Tables 5-4 through 5-9 can be used to compare plant-specific program coverage against programs/techniques determined to be effective at detecting and mitigating the significant aging mechanisms.

\subsection{References}

1.1 Title 10, U.S. Code of Federal Regulations, 10 CFR Part 54, "Requirements for Renewal of Operating Licenses for Nuclear Power Plants," December 13, 1991.

1.2 EPRI Report NP-2331, "Steam Generator Corrosion Studies."

1.3 EPRI Report NP-5565, "Vibration and Wear Prediction for Steam Generator Tubes," June 1988.

1.4 Generic Letter 89-13, "Service Water System Problems Affecting Safety-Related Equipment," July 18, 1989. 


\section{INTRODUCTION}

\subsection{Background}

The DOE-sponsored Plant Lifetime Improvement (PLIM) Program, in cooperation with EPRI Life Cycle Management (LCM) Program, is establishing and demonstrating a predictable license renewal process for existing light water reactors (LWRs) in the United States An important element of this program is the development of Nuslear Management and Resource Council (NUMARC, now the Nuclear Energy Institute, NEI) License Renewal Industry Reports (IRs), which cover critical classes of equipment such as reactor pressure vessels, reactor coolant pressure boundary piping, containment structures, and cables. To support continued demonstration of PLIM and LCM concepts, there is a need for further industry development of guidelines that describe and evaluate acceptable aging management approaches for several groupings of equipment not evaluated in the IRs. This AMG evaluates heat exchangers determined to be important to license renewal. [2.1]

Continued operation of nuclear power plants for periods that extend beyond the original 40-year license period may be desirable for many U.S. nuclear plant operators. To allow operation of the plant during a license renewal period, utilities must show that the aging of components important to license renewal has been managed such that these components will not degrade to the extent that they are incapable of supporting required functions. Therefore, to control the aging of components important to license renewal during the license renewal period, operators of nuclear power plants must identify and perform activities necessary to manage the aging of components so that proper function is assured.

For components to retain their capability to perform required function(s) during the license renewal period, activities such as preventive maintenance and refurbishment may be necessary during the current license period even though some of these activities may not be necessary to guarantee function during the current license period. These activities would be necessary to assure that there is no loss of required function(s), no unacceptable reduction in safety margins, and that higher rates of challenge to plant safety systems do not occur during the license renewal period.

\subsection{Purpose and Objectives}

The purpose of this AMG is to provide cost-effective, practical methods to plant technical staff for the effective management of aging of heat exchangers used in commercial nuclear power plants. An effective aging management program will ensure that each heat exchanger will continue to perform its function or will not prevent performance of a required function during the current license period and during the license renewal term.

The objective of this AMG is to provide an analysis of the potential degradation modes for heat exchangers and to provide acceptable guidelines for developing effective aging management programs that will detect and mitigate the significant aging mechanisms.

This AMG is intended for use by nuclear plant personnel performing heat exchanger aging management evaluations and provides information and guidance that will be valuable in the 
formulation of the plant's aging management programs. This AMG also provides additional value to nuclear plant operators as follows:

1. The AMG is a well-researched technical document that can be used by maintenance and system engineering personnel for the identification, characterization, and management of age-related degradation in heat exchangers. It can also be used as a base document for plants developing a license renewal application.

2. The results in this $\mathrm{AMG}$ are based on an extensive literature search. Therefore, nuclear plant personnel can use this AMG as an exhaustive reference for relevant information about heat exchangers. Some of the references used include:

- EPRI Reports

- NRC Bulletins, Information Notices, Circulars, Generic Letters and Reports

- Code of Federal Regulations (CFR)

- Vendor Manuals

- American Society of Mechanical Engineers (ASME) Codes and Standards

- Miscellaneous References and Technical Papers

3. This AMG consolidates historical maintenance and industry operating information into one source. The plant maintenance/system engineer will find this useful for both the identification of age-related degradation (including root causes) and the verification of appropriate corrective action. Issues discussed in the AMG include:

- Equipment design differences relevant to aging considerations

- Equipment obsolescence as it affects aging management

- Service environments

- Operating and maintenance history from the Institute for Nuclear Power Operations (INPO) NPRDS and NRC Licensee Event Report (LER) databases

- Historical overhaul data from refurbishment facilities

- Additional operating and maintenance history from responses to plant surveys

4. Heat exchanger aging phenomena are described in detail. This will be useful for heat exchanger maintenance interval and reliability evaluations. The following topics are discussed:

- Stressors acting on heat exchanger subcomponents

- Aging mechanism identification 
- Significance of aging mechanisms using "if/hen" criteria

- Age-related degradation of heat exchanger subcomponents

- Potential failure modes

5. The AMG can be an effective tool for heat exchanger aging management and personnel training. The AMG:

- Identifies the need for aging management and compliance with Maintenance Rule requirements

- Contains a correlation between the scope and frequency of maintenance practices and heat exchanger performance and rate of degradation

- Presents information that can be used in the construction of meaningful life-cycle management charts and to improve the accuracy of cost/benefit determinations

- Discusses both conventional and non-conventional maintenance techniques, and considers how these practices can be utilized to effectively manage equipment aging

- Characterizes initiation and progression of equipment aging for use in training F.: sontuc responsible for maintenance and inspection activities

- Identifies concepts, principles, and methods for evaluating heat exchangers not in the scope of this AMG.

\subsection{Contents of Aging Management Guideline}

The nuclear plant heat exchangers selected for evaluation in this AMG were chosen from previous BWR and PWR Lead Plant License Renewal studies, draft NUREG-1299 [2.2], and Appendix B of Draft Regulatory Guide DG-1009 [2.3]. Heat exchangers that are unique with respect to manufacturer/models, or are used in only one or very few plants (for example, isolation condensers in BWR plants and ice condensers in PWR plants) were not selected for evaluation in this AMG. The BWR and PWR Lead Plant License Renewal studies relied on a screening process to identify and select specific system heat exchangers that are important to license renewal. The screening process uses a systematic approach to identify heat exchangers with important-to-safety operating functions or that contribute to initiating or challenging safety systems. Table 2-1 identifies those PWR and BWR plant heat exchangers evaluated in this AMG.

Section 3 lists and describes the components evaluated, component boundaries and discusses manufacturers' design differences. It also includes a discussion of the design requirements that apply to heat exchangers, including applicable Codes, Standards, and Regulations. Lastly, Section 3 includes a detailed study of the operating history of the components evaluated from LER data, NPRDS data, and from other sources. 


\section{AGING MANAGEMENT GUIDELINE FOR HEAT EXCHANGERS}

\begin{tabular}{l|l}
\hline \multicolumn{1}{l}{ Table 2-1. Heat Exchangers in Scope of AMG } \\
Heat Exchangers Located in BWR Plants
\end{tabular}

Notes:

1. Includes various system names, such as component cooling water, emergency equipment cooling water, essential equipment cooling water, reactor building closed cooling water, auxiliary building closed cooling water and essential service water.

2. Includes various system names, such as deciay heat removal, low pressure coolant injection, shutdown cooling.

3. Includes various system names, such as safety injection, shutdown cooling, and decay heat removal. 
Section 4 discusses stressors acting on the subcomponents. Stressors produce aging mechanisms that can cause component degradation. The results of aging studies are used to describe the aging mechanisms (see Table 2-2) known to cause degradation. An aging mechanism is significant when, if allowed to continue without detection or mitigation measures, it will cause the component to lose its ability to perform its required function. Aging mechanisms for the subcomponents are identified and uvaluated. Operational demands, environmental conditions, failure data, and industry operations and maintenance history are considered, and the significance of the aging mechanisms determined.

\section{Table 2-2. Aging Mechanisms}

I. Fatigue
A. High Cycle
B. Low Cycle
C. Thermal

II. Corrosion
A. General
B. Pitting
C. Galvanic
D. Microbiologically Influenced Corrosion

III. Stress Corrosion Cracking
A. Intergranular
B. Irradiation Assisted
C. Transgranular

IV. Erosion and Erosion/Corrosion

V. Embrittlement
A. Thermal
B. Neutron

VI. Wear
A. Adhesive
B. Abrasive
C. Erosive

VII. Stress Relaxation

VIII. Creep

IX. Fouling 
Section 5 discusses effective aging management techniques for aging mechanisms determined to be significant in Section 4. Conventional maintenance, inspection, testing, and surveillance techniquus or programs are described. A brief discussion of nonconventional activities and techniques is also included. The effectiveness of these techniques or programs to manage the significant aging mechanisms is described. Variations in plant aging management programs or techniques are considered. Requirements for an effective technique or program are presented in the form of "if/then" criteria whenever possible.

Section 6 discusses management options, if applicable, to deal with action items identified in Section 5.

\subsection{Generic License Renewal Requirements}

10 CFR 54.21 [2.1] describes the requirements for the content of technical information in the license renewal application. ${ }^{*}$ Section 54.21 states that a supplement to the FSAR must be prepared that contains an Integrated Plant Assessment (IPA) that must:

1. identify and list all systems, structures, and components (SSCs) important to license renewal.

2. identify those structures and components (SCs) that contribute to the performance of a required function or could, if they fail, prevent an SSC important to license renewal from performing its required function.

3. for the identified SCs, determine those that could have age-related degradation that is unique to license renewal.

To identify the age-related degradation ${ }^{* *}$ that is unique to license renewal (in item (a)(3) of Section 54.21), the definition of age-related degradation unique to license renewal must be applied. Age-related degradation unique to the license renewal period is degradation:

1. that occurs during the term of the current operating license, but whose effects are different in character or magnitude after the term of the current operating license (the period of extended operation); or

2. whose effects were not explicitly identified and evaluated by the licensee for the period of extended operation and the evaluation found acceptable by the NRC; or

3. that occurs only during the period of extended operation.

\footnotetext{
* The NRC is in the process of a rule change regarding 10 CFR 54 at the time of this writing.

** See list of definitions in Appendix A for aging terminology used in this report.
} 
This AMG does not make the distinction of whether or not an aging mechanism is or is not unique to license renewal. This AMG evaluates all potentially significant aging mechanisms.

The criteria for determining SSCs important to license renewal, the criteria for evaluating whether an SC is necessary for the performance of a required function, and the technical criteria used to determine whether an SC is subject to age-related degradation unique to license renewal must be defined.

For each of the SCs having age-related degradation that is unique to license renewal, the age-related degradation must be addressed by an effective program or shown not to need to be addressed by an effective program. An effective program is a documented program to manage age-related degradation unique to the license renewal period that ensures that a SSC important to license renewal will continue to perform its required function or will not prevent the performance of a required function during the period of extended operation.

The effective program must:

1. identify and mitigate age-related degradation unique to license renewal

2. contain acceptance criteria against which the need for corrective action can be evaluated and assure timely corrective action when the acceptance criteria are not met

3. be implemented by the facility operating procedures and reviewed by the onsite review committee.

10 CFR 54.21 continues with a discussion of changes to the current licensing basis and plant modifications, which are outside the scope of this report.

Additionally, this AMG supports the determination that existing aging management practices are satisfactory for fulfilling license renewal requirements and meeting review conditions stated in the draft version of NUREG-1299, "Standard Review Plan for the Review of License Renewal Applications for Nuclear Power Plants." [2.2] Components included in the classification of important to license renewal are identified, and stressors, aging mechanisms, and failure modes for these components are defined. Furthermore, this AMG states the type of existing practices that are acceptable for the management of aging as well as areas requiring further plant-specific evaluation. Exemptions and requests for relief (pursuant to 10 CFR 50.12 and 10 CFR 50.55a, respectively) were not considered under this AMG in that these issues are plant-specific in nature and therefore must be considered on a plant-by-plant basis.

This report evaluates heat exchangers with respect to the requirements of 10 CFR 54.21 and provides a discussion of the types of heat exchangers important to license renewal and the age-related degradation affecting components and subcomponents of heat exchangers. The following sections detail the analysis leading to the determination of age-related degradation and the means necessary to address it. 


\subsection{Method Used to Define the Scope of Components Important to License Renewal}

To determine the heat exchangers covered by license renewal requirements, the definition of SSCs important to license renewal [2.1] must be evaluated. The current definition of SSCs important to license renewal includes:

1. Safety-related SSCs, which are those relied upon to remain functional during and following design basis events to ensure:

(i) The integrity of the reactor coolant pressure boundary;

(ii) The capability to shut down the reactor and maintain it in a safe shutdown condition; or

(iii) The capability to prevent the consequences of accidents that could result in potential offsite exposure comparable to the 10 CFR 100 guidelines.

2. All non-safety-related SSCs whose failure could directly prevent satisfactory accomplishment of any of the required functions identified in paragraphs (1) (i), (ii), or (iii) of this definition.

3. All SSCs relied on in safety analyses or plant evaluations to demonstrate compliance with the Commission's regulations for fire protection (10 CFR 50.48), environmental qualification (10 CFR 50.49), pressurized thermal shock (10 CFR 50.61), anticipated transients without scram (10 CFR 50.62), and station blackout (10 CFR 50.63).

4. All SSCs subject to operability requirements contained in the facility's Technical Specifications' Limiting Conditions for Operation.

The evaluation of this definition, with respect to heat exchangers and the components determined to be important to license renewal, is given in Section 3.1. Note that the scope of heat exchangers covered under the Maintenance Rule, 10 CFR 50.65, is almost the same as that covered by the License Renewal Rule, 10 CFR 54.21.

\subsection{Method Used to Define Aging Mechanisms Assessed in This Study}

To define the aging mechanisms assessed in this study, a two-part evaluation was performed. First, the effects of stressors, such as mechanical, hydraulic, chemical, electrical and environmental, on equipment operation were determined. The aging mechanisms associated with those stressors that cause degradation were then determined. This evaluation is contained in Section 4.1.

Second, industry-wide operating experience (particularly that reported in NRC LERs; Information Notices, Bulletins, and Circulars; and INPO NPRDS data) was examined. A review of the NRC Information Notices, Bulletins, and Circulars was conducted to identify age-related failures. The aging mechanisms associated with reported age-related failures were then 
determined. Events described in the NPRDS data and LERs were then analyzed for age-related degradation and failures to identify the numbers of particular types of failures. The aging mechanisms associated with these failures were then determined. This review of industry-wide operating experience is contained in Section 3.6.

This multi-source analysis (i.e., using data from NPRDS and NRC documentation) provides a comprehensive characterization of equipment aging by using actual plant and vendor data to substantiate and refine those aging mechanisms postulated to occur due to stressors.

After a list of all possible aging mechanisms was developed (see Table 2-2 and Section 4.2), the significance of each aging mechanism was determined. Those aging mechanisms that were confirmed by operating or overhaul experience, had a high probability of occurrence, or would result in a failure having a large impact on equipment operation were designated as significant aging mechanisms. Those aging mechanisms designated as significant are discussed in Section 4.3.1 and 4.3.2. Those aging mechanisms designated nonsignificant are also discussed in 4.3.1.

Conventional maintenance, inspection, testing, and surveillance techniques or programs determined to effectively manage aging of heat exchangers are discussed in Section 5.2. A brief discussion of nonconventional activities and techniques is provided in Section 5.3. The aging management techniques and programs that effectively manage the significant aging mechanisms are discussed in Section 5.4. The evaluation conclusions derived in Section 5.4 show that all significant aging mechanisms are effectively managed by current techniques and programs. Therefore, no other aging management enhancements for the significant aging mechanisms are required.

It should be noted that aging mechanisms and their associated degradations were not categorized either as occurring in the current license period or as being unique to license renewal. Aging as a whole is covered in this document. There is no generically applicable methodology that has been agreed upon for identifying those age-related degradation mechanisms that are unique to license renewal. It is understood that by not using the definition of age-related degradation unique to license renewal the scope of components evaluated is larger. This is intended because this AMG is intended for use by utilities that may submit a license renewal application and those who simply wish to understand aging of heat exchangers during the first 40 years of operation. Therefore, the approach herein identifies those techniques that manage aging mechanisms to preclude adverse effects during the current and license renewal periods.

To provide a basis for the discussions of stressors, aging mechanisms, and failure modes, Section 3 describes heat exchangers that are in common use in the nuclear industry. Appendix A provides definitions of aging terminology used in this report.

\subsection{References}

2.1 Title 10, U.S. Code of Federal Regulations, 10 CFR Part 54, "Requirements for Renewal of Operating Licenses for Nuclear Power Plants," December 13, 1991. 
2.2 Draft NUREG-1299, "Standard Review Plan for the Review of License Renewal Applications for Nuclear Power Plants," November 1990.

2.3 Draft Regulatory Guide, DG-1009, "Standard Format and Content of Technical Information for Applications to Renew Nuclear Power Plant Operating Licenses," December 1990. 


\section{EQUIPMENT/COMPONENTS EVALUATED: SCOPE}

This section of the AMG identifies the LWR heat exchangers to be evaluated. Sections 3.1 through 3.4 describe the selection methodology, the heat exchangers in the evaluation scope, and the groupings of heat exchangers, components, and service applications established for evaluation. The key design codes and standards, operating history, and the associated aging implications are discussed in Sections 3.5 and 3.6, respectively.

\subsection{Heat Exchanger Selection Methodology}

Identifying the heat exchangers to be evaluated involved the review of industry documents, plant documents for a typical BWR and PWR, and a survey of utility engineers. The review of industry documents included the following:

1. Review of 10 CFR 54, Definitions of Systems, Structures, and Components Important to License Renewal [3.1] (License Renewal Rule).

2. Review of BWR Lead Plant Project Technical Reports.

3. Review of PWR Technical Demonstration Project (EPRI) Technical Findings.

4. Review of 10 CFR 50.65, Maintenance Rule and Draft NUMARC Industry Guideline $[3.2,3.3]$.

5. Draft NUREG/CR-5779, "Aging of Non-Power-Cycle Heat Exchangers Used in Nuclear Power Plants" [3.4].

These documents provide current industry thinking with respect to selecting the heat exchangers evaluated and identifying the aging and performance issues. The License Renewal Rule and Maintenance Rule use similar criteria for selecting systems, structures, and components that need to be addressed. The License Renewal Rule focuses on the detection and mitigation of age-related degradation, while the Maintenance Rule focuses on maintaining performance. The methodology used to select the heat exchangers evaluated in this AMG is provided in Section 2.5. The list of heat exchangers selected (Table 3-1) compares favorably with the scope of heat exchangers provided in Draft Regulatory Guide for License Renewal (DG-1009, Appendix B) and the Standard Review Plan for License Renewal (NUREG-1299, Section C.1.4).

The review of industry documents resulted in an initial listing of heat exchangers (Table 3-1). Safety analysis reports from several plants were consulted to verify that the listing is representative for all plants, and of the types of heat exchangers used in the above functions. This activity determined that plants may use different heat exchanger name designations, but their configuration, functions, and aging characteristics are bounded by the Table 3-1 listing.

A survey/questionnaire was sent to all operating commercial nuclear power plants in the United States. Plant-specific heat exchanger data was provided by fourteen units; of the fourteen, four provided maintenance and operating histories. This data was used for comparison of heat exchanger selection and for comparison to industry document summaries of maintenance and 


\section{A. jING MANAGEMENT GUIDELINE FOR HEAT EXCHANGERS}

operation histories. Utility data compared favorably with heat exchanger selection and historical data.

\section{Table 3-1. Heat Exchangers Evaluated}

\begin{tabular}{|c|c|}
\hline BWR Plant Heat Exchangers & PWR Plant Heat Exchangers \\
\hline $\begin{array}{l}\text { Component Cooling Water Heat Exchangers } \\
\text { (Note 1) }\end{array}$ & $\begin{array}{l}\text { Chemical and Volume Control Excess Letdown } \\
\text { Heat Exchangers }\end{array}$ \\
\hline Drywell Coolers & $\begin{array}{l}\text { Chemical and Volume Control Letdown Heat } \\
\text { Exchangers }\end{array}$ \\
\hline Emergency Core Cooling System Room Coolers & $\begin{array}{l}\text { Chemical and Volume Control Regenerative Heat } \\
\text { Exchangers }\end{array}$ \\
\hline Emergency Diesel Generator Jacket Water Coolers & $\begin{array}{l}\text { Chemical and Volume Control Seal Water Heat } \\
\text { Exchangers }\end{array}$ \\
\hline $\begin{array}{l}\text { Emergency Diesel Generator Lubrication Oil } \\
\text { Coolers }\end{array}$ & $\begin{array}{l}\text { Component Cooling Water Heat Exchangers } \\
\text { (Note 1) }\end{array}$ \\
\hline $\begin{array}{l}\text { High Pressure Coolant Injection Gland Seal } \\
\text { Condensers }\end{array}$ & Emergency Core Cooling System Room Coolers \\
\hline $\begin{array}{l}\text { High Pressure Coolant Injection Lubrication Oil } \\
\text { Coolers }\end{array}$ & Emergency Diesel Generator Jacket Water Coolers \\
\hline Miscellaneous Oil Coolers & $\begin{array}{l}\text { Emergency Diesel Generator Lubrication Oil } \\
\text { Coolers }\end{array}$ \\
\hline $\begin{array}{l}\text { Reactor Core Isolation Cooling Lubrication Oil } \\
\text { Coolers }\end{array}$ & Miscellaneous Oil Coolers \\
\hline $\begin{array}{l}\text { Reactor Water Cleanup Non-Regenerative Heat } \\
\text { Exchangers }\end{array}$ & Residual Heat Removal Heat Exchangers (Note 3) \\
\hline $\begin{array}{l}\text { Reactor Water Cleanup Regenerative Heat } \\
\text { Exchangers }\end{array}$ & Spent Fuel Pool Cooling Heat Exchangers \\
\hline Residual Heat Removal Heat Exchangers (Note 2) & \\
\hline Spent Fuel Pool Cooling Heat Exchangers & \\
\hline
\end{tabular}

Notes:

1. Includes various system names, such as component cooling water, emergency equipment cooling water, essential equipment cooling water, reactor building closed cooling water and essential service water

2. Includes various system names, such as decay heat removal, low pressure coolant injection, shutdown cooling, and containment cooling.

3. Includes various system names, safety injection, shutdown cooling, and decay heat removal. 


\subsection{Evaluation Scope}

The heat exchanger selection methodology described in Section 3.1 was used to establish the listing of BWR and PWR heat exchangers in Table 3-1. These heat exchangers are evaluated in this AMG. Steam generators (PWR) have been extensively evaluated in other industry studies (for example, References 3.5 and 3.6) and therefore are not in the scope of this AMG.

Heat exchanger designs are described in Section 3.4. With the exception of containment or room coolers, which are finned coil type with air on the outside of the tubes, the predominant heat exchanger type is shell-and-tube which can be shell-and-U-tube, or shell-and-straight-tube. Carbon steel is generally used for the shell. Austenitic stainless steel, admiralty, ferritic and carbon steel, and other alloys are used for the tubes. Copper, copper-nickel $(\mathrm{Cu}-\mathrm{Ni})$, and austenitic stainless steels are some of the materials used in fin-coil tubes. Some of the heat exchangers operate continuously while others are in standby (only operated during periodic testing or maintenance).

\subsection{Component Boundaries}

For shell and tube heat exchangers, the boundaries of the evaluation are defined by the shell and its nozzles for piping attachments, and the channel head and its nozzles for piping attachments. The attached valves, drain connections, and piping are outside the component boundary. For air-to-water heat exchangers, the boundaries of the evaluation are defined by the tube headers and their nozzles for piping attachments. Associated blowers, air-flow-directing ducting, and most housings are not evaluated in this AMG. Figure 3-1 illustrates typical heat exchanger component boundaries.
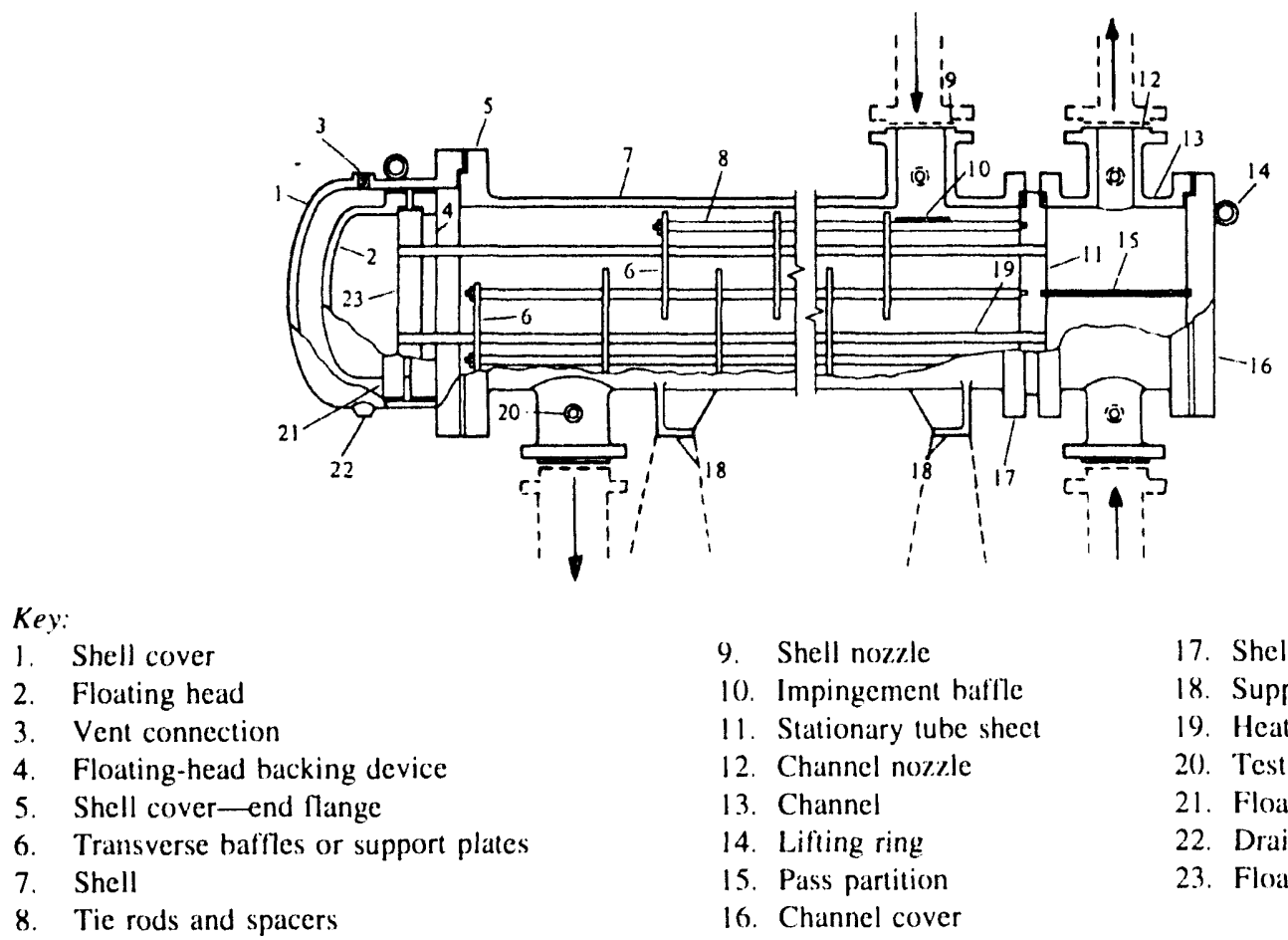

9. Shell nozzle
10. Impingement haffle
11. Stationary tube sheet
12. Channel nozzle
13. Channel
14. Lifting ring
15. Pass partition
16. Channel cover

17. Shell channel-end flange

18. Support saddles

19. Heat-Iransfer tube

20. Test connection

21. Floating-head flange

22. Drain connection

23. Floating tube sheet

Figure 3-1. Shell and Tube Heat Exchanger with Floating Head [3.7]. 


\subsection{Description of Components Evaluated}

This section describes the heat exchangers and the associated subassemblies and cor:uponents evaluated in this AMG.

\subsubsection{Major Heat Exchanger Types}

Heat exchangers are devices that transfer heat to establish or maintain desired process or equipment temperatures. Several heat exchanger types are used in nuclear power plants, many serving as interfaces between plant systems. The major heat exchanger types (i.e., Figures 3-1, 3-2, 3-3, and 3-4) utilized in nuclear power plants are the shell-and-tube heat exchanger and the fin-coil cooling units. Figures 3-1, 3-2, 3-3, and 3-4 are reproduced from reference [3.7]. These types of heat exchangers are described below.

\section{Shell-and-Tube Heat Exchangers}

In the shell-and-tube heat exchanger, one fluid flows inside the tubes while the other fluid is forced through the shell and over the outside of the tubes. Normally, to permit effective cleaning in a shell-and-tube heat exchanger, the fluid with the highest fouling potential is on the tube side. The reason for forcing the fluid to flow over the tubes rather than along them is that a higher heat-transfer coefficient can be achieved in cross flow. To achieve cross flow on the shell side, baffles are placed inside the shell as shown in Figure 3-2. These baffles ensure that flow passes across the tubes, section-by-section for the entire length of the heat exchanger. Depending upon the header arrangements at the two ends of the heat exchanger, one or more tube passes can be achieved. For a two-tube pass arrangement, the inlet header is split so that the fluid flowing into the tubes passes through one-half of the tubes in one direction, reverses direction and returns through the other half of the tubes to the opposite side of the channel head, as shown in Figure 3-2. A one tube pass arrangement is called shell-and-straight-tube while a two tube pass arrangement is often referred to as shell-and-U-tube. Three and four tube passes can also be achieved by rearrangement of the header space. The most common kind of baffle used is the disk-and-doughnut baffle, shown at Figure 3-3.

The heat exchanger shown in Figure 3-2 has fixed tube plates (i.e., tube sheet) at each end and the tubes are welded or expanded into the plates. This construction has a low cost but it cannot be used for high temperature differences because no provision is made for differential

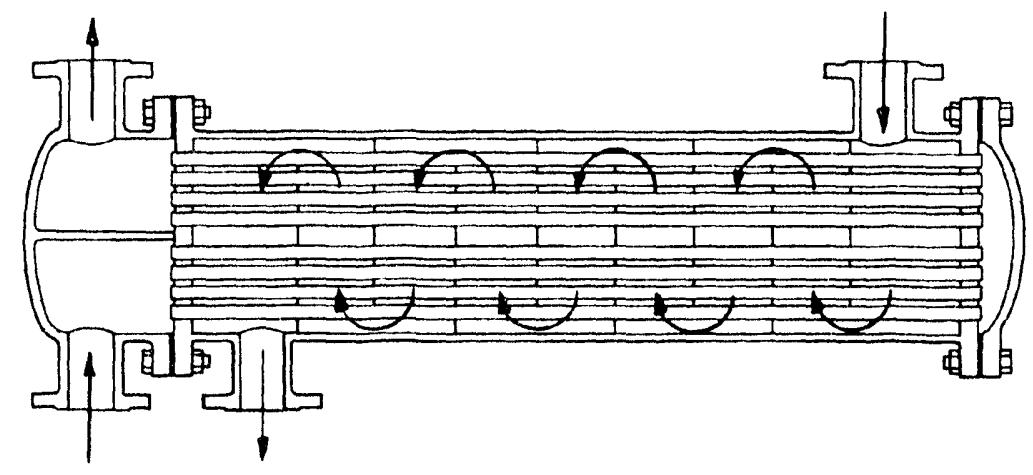

Figure 3-2. Shell and Tube Heat Exchanger with Segmental Baffles [3.7]. 


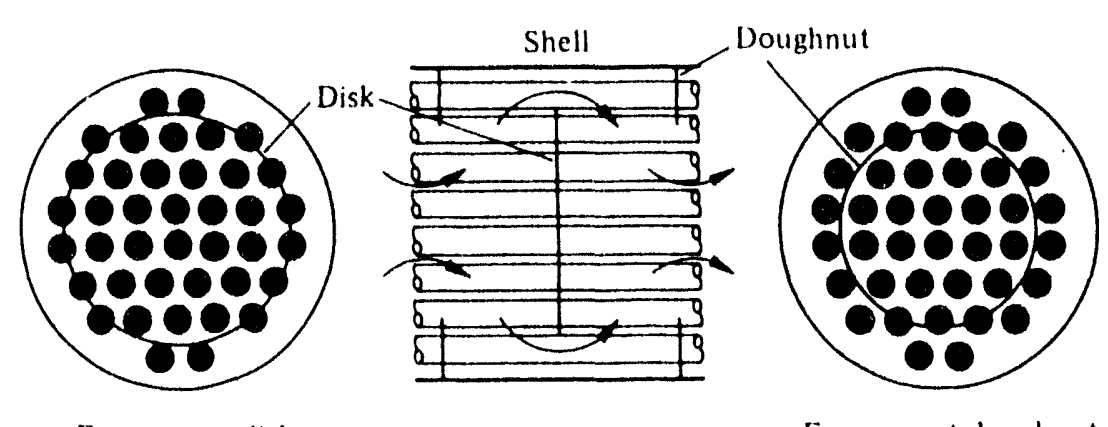

Free area at disk

Free area at doughnut

Figure 3-3. Common Heat Exchanger Baffle Arrangement [3.7].

thermal expansion between tubes and shell. Also, the tube bundle cannot be removed for cleaning. A different arrangement can overcome these drawbacks. In this arrangement, one tube plate is fixed but the other is bolted to a floating-head cover which permits the tube bundle to move relative to the shell. The floating tube sheet is clamped between the floating head and a flange so that it is possible to remove the tube bundle for cleaning. Figure 3-1 illustrates this arrangement. Shell-and-tube heat exchangers are used for all water-to-water heat transfer applications. The fluids can be primary water, treated water, raw (service) water, borated water. closed cooling water, or lubricating oil.

\section{Fin-Coil Units}

This type of heat exchanger is used for containment or room cooling. In these heat exchangers, the water flows through the tubes, whereas the air is forced across the tube bundle. The flow of air is by forced convection, using fans. The type of exchanger used in nuclear power plants is the finned coil type. In this arrangement, the air flows across a finned tube bundle and is unmixed (meaning it cannot move freely) because it is confined in separate flow passages during the process. A cross-flow heat exchanger is shown on Figure 3-4.
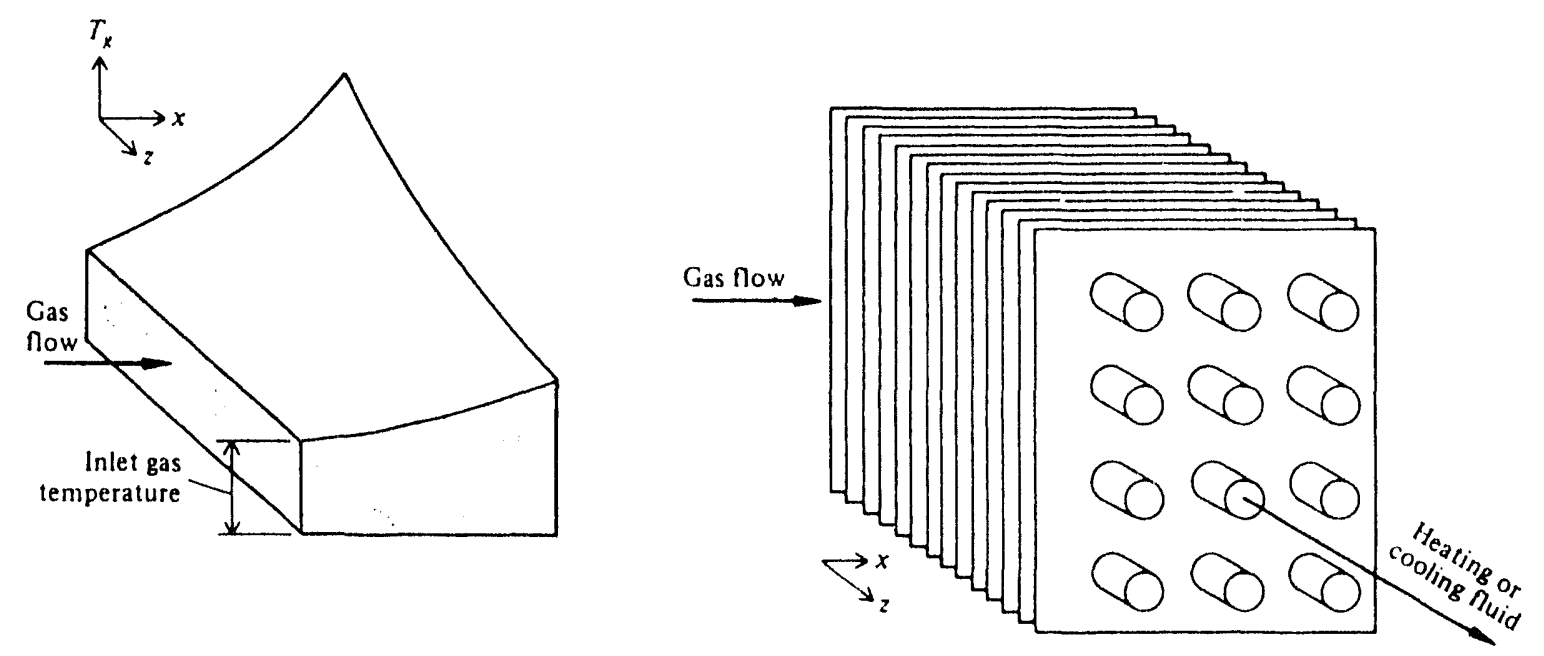

Figure 3-4. Cross Air Flow Heat Exchanger [3.7]. 


\subsubsection{Common Components}

Each heat exchanger can be broken down into subassemblies and components. Table 3-2 lists the heat exchanger component groups and subcomponents. The subassembly names corresponds with their general function. Commonly used materials of construction for each component are listed in Table 3-3. Manufacturer design differences are identified and discussed in Section 3.4.4.

\section{Table 3-2. Heat Exchanger Component Groups and Subcomponents}

Shell-and-Tube Heat Exchangers

Tubes

Tube Sheets

Shell/Nozzles

Shell Side Internals

Floating Head

Impingement Plates

Tie Rods

Baffle Plates/Partitions

Pressure Boundary Fasteners/Flange

Waterbox/Channel Head/End Bell

Divider Plate

Sacrificial Anodes

Support Assembly

Fin-Coil Heat Exchangers

Coil Headers

Nozzles

Coils Tubes Fins 


\section{Table 3-3. Typical Heat Exchanger Materials}

Tubes/Coils

Austenitic Stainless Steel, Admiralty Brass, Copper-Nickel, Titanium, Copper

Tube Sheets

Carbon Steel, Austenitic Stainless Steel, Muntz (copper alloy)

Shell/Nozzles/Internals

Carbon Steel, Austenitic Stainless Steel

Baffle Plates

Carbon Steel, Austenitic Stainless Steel

Divider Plate

Carbon Steel, Austenitic Stainless Steel

Fasteners

Forged Stainless Steel, Forged Carbon Steel

Waterbox

Carbon Steel, Austenitic Stainless Steel

\begin{tabular}{|c|c|}
\hline & $\begin{array}{c}\text { Typical Materials for ASME Class 1, 2, and 3 } \\
\text { Pressure-Retaining Boundary Parts }\end{array}$ \\
\hline $\begin{array}{c}\text { Carbon Steel } \\
\text { Castings }\end{array}$ & SA-261, Gr WCA, WCB, WCC \\
Forgings & SA-105, Gr I, II \\
Plate & SA-515, Gr 55, 60, 65, 70) \\
Bolting & SA-193, Gr B6, B7, B8, B16 \\
Stainless Steel & \\
Castings & SA-351, Gr AZ (304), CF8M (316) \\
Forgings & SA-182, Gr 304, 316, 321,347 \\
Plate & SA-240, Gr 304, 316, 321,347 \\
Nonferrous & \\
A limited number of nonferrous mi erials are permitted.
\end{tabular}

It is regarded as standard maintenance practice to replace or refurbish various components or component parts during normal maintenance activities. These components and parts are designated as "renewable" for the purpose of evaluation. Plant programs are stipulated to be inherently effective to manage "renewables." The following items are therefore designated as renewable components for heat exchangers. Evaluations and additional actions to detect and mitigate age-related degradation for the following components are not required.

$\begin{array}{lll}\text { Bolts }^{*} & \text { Keys, Pins } & \text { Studs }^{*} \\ \text { Coatings } & \text { Nuts } & \text { Thermal Insulation } \\ \text { Gaskets } & \text { Screws }^{*} & \text { Washers }\end{array}$

"Except pressure retaining fasteners for components in the ASME Section XI ISI Program. 


\subsubsection{Service Applications and Environments}

Aging mechanism evaluations require a clear understanding of environments to which heat exchanger subcomponents are exposed. The potential heat exchanger component environments are the process and cooling fluid streams and the external environment. The heat exchanger subcomponent environments are summarized in Table 3-4. Tables 3-5 and 3-6 show the process and cooling fluid media for BWR and PWR heat exchangers, respectively.

\section{Table 3-4. Heat Exchanger Subcomponent Environments}

\begin{tabular}{|c|c|c|c|}
\hline Subcomponent & Tube Side Fluid & Shell Side Fluid & External Ambient \\
\hline Tubes (Note 1) & $\mathrm{X}$ & $\mathrm{x}$ & -. \\
\hline \multicolumn{4}{|l|}{ Fin-Coils } \\
\hline - Coils & $\mathrm{x}$ & Atmosphere & $\mathrm{x}$ \\
\hline - Coil Headers & $\mathrm{x}$ & Atmosphere & $\mathrm{X}$ \\
\hline Tube Sheet (Note 2) & $x$ & $\mathrm{x}$ & -- \\
\hline \multicolumn{4}{|l|}{ Shell } \\
\hline - Shell & -. & $\mathrm{x}$ & $\mathrm{X}$ \\
\hline - Nozzles & -- & $\mathrm{x}$ & $\mathrm{X}$ \\
\hline - Impingement Plates & -- & $\mathrm{x}$ & - \\
\hline - Shell Cover & $X$ (Note 3$)$ & -- & $\mathrm{x}$ \\
\hline - Floating Head & $\mathrm{X}$ & -. & $\mathrm{x}$ \\
\hline - End Flange & -- & -- & $\mathbf{X}$ \\
\hline - Partitions/Baffle Plates & - & $\mathrm{x}$ & -- \\
\hline
\end{tabular}

\section{Waterbox}

- Divider Plate

- Channel

- Channel Head

- Nozzles

- Sacrificial Anodes

Pressure Boundary Flanges/Fasteners and Support

Assembly

Legend:

$X$ The heat exchanger subcomponent is exposed to the indicated fluid conditions. Table 3-5 and 3-6 shows the type of fluids for the various heat exchangers.

-. The heat exchanger subcomponent is not exposed to the indicated fluid conditions.

Notes:

1. The tubes are in contact with the tube-side fluid at the tube internal surface, and with the shell-side fluid at the external surface

2. The tube sheets are the interface between the shell interior and the waterbox/channel head.

3. If there is a floating head, the shell cover will not be in contact with the fluid. 
Table 3-5. Process and Cooling Fluid Media BWR Heat Exchangers BWR Heat Exchanger

Tube Side Fluid

Shell Side Fluid

\begin{tabular}{lll}
\hline Component Cooling Water (Note 1) & Raw Water & Closed Cooling Water \\
Drywell Coolers & Closed Cooling Water & Drywell Atmosphere \\
Emergency Core Cooling System Room Coolers & Raw Water & Reactor Building Atmosphere \\
Emergency Diesel Generator Jacket Water & Raw Water & Closed Cooling Water \\
Emergency Diesel Generator Lubrication Oil & Raw Water & Lubrication Oil \\
High Pressure Coolant Injection Gland Seal & Treated Water & Primary Water \\
Condenser & & \\
High Pressure Coolant Injection Lubrication Oil & Treated Water \\
Miscellaneous Oil Coolers & Closed Cooling Water & Lubrication Oil \\
Reactor Core Isolation Cooling Lubrication Oil & Treated Water & Lubrication Oil \\
Reactor Water Cleanup Non-Regenerative & Primary Water & Closed Cooling Water \\
Reactor Water Cleanup Regenerative & Primary Water & Primary Water \\
Residual Heat Removal (Note 2) & Raw Water & Treated Water \\
Spent Fuel Pool & Treated Water & Closed Cooling Water
\end{tabular}

Notes:

1. Includes various system names, such as component cooling water, emergency equipment cooling water. essential equipment cooling water, reactor building closed cooling water, auxiliary building closed cooling water and essential service water.

2. Includes various system names, such as decay heat removal, low pressure coolant injection, shutdown cooling, and containment cooling. 
Table 3-6. Process and Cooling Fluid Media PWR Heat Exchangers

PWR Heat Exchanger

Chemical and Volume Control System Excess

Letdown

Chemical and Volume Control Letdown

Chemical and Volume Control Regenerative

Chemical and Volume Control System Seal Water

Component Cooling Water (Note 1)

Containment Air Coolers

Emergency Core Cooling System Room Coolers

Emergency Diesel Generator Jacket Water

Emergency Diesel Generator Lubrication Oil

Miscellaneous Oil Coolers

Residual Heat Removal (Note 2)

Spent Fuel Pool
Tube Side Fluid

Shell Side Fluid

Primary Water

Primary Water

Primary Water

Primary Water

Raw Water

Raw Water

Raw Water

Raw Water

Raw Water

Closed Cooling Water

Primary Water

Treated Water
Closed Cooling Water

Closed Cooling Water

Primary Water

Closed Cooling Water

Closed Cooling Water

Containment Atmosphere

Atmosphere

Closed Cooling Water

Lubrication Oil

Lubrication Oil

Closed Cooling Water

Closed Cooling Water

Notes:

1. Includes various system names, such as component cooling water, emergency equipment cooling water, essential equipment cooling water, reactor building closed cooling water, auxiliary building closed cooling water and essential service water.

2. Includes various system names such as low pressure safety injection, shutdown cooling, and decay heat removal.

\subsubsection{Service Applications (Circulating Fluids)}

The characteristics and/or properties of the circulating fluids define the service application. The heat exchangers included in the scope of this AMG transfer heat from one system to another. The different types of circulating fluids are:

(1) Raw Water

Fresh Water. Fresh Water entering the plant from a river, lake, pond, or bay which has not been chemically treated or demineralized. In general, the water has been rough-filtered to remove large particles and contains biocidal additives for microorganism control. The sodium chloride content is typically below $1000 \mathrm{mg} / \mathrm{l}$ $18.3 \times 10^{-3} \mathrm{lbm} / \mathrm{gall}$. 
Salt (Brackish) Water. Water entering the plant from a river or ocean with a sodium chloride content greater than $1000 \mathrm{mg} / 1\left[8.3 \times 10^{-3} \mathrm{lbm} / \mathrm{gal}\right]$. This water, like fresh water, in general has been rough-filtered and contains biocidal additives.

(2) Treated Water

Water which has been filtered and demineralized but generally not deaerated. The water may contain up to $5 \mathrm{ppm}$ dissolved oxygen and small amounts of chemicals (i.e. potassium chromate, sodium nitrite, etc.) for process use. The spent fuel pool water in PWR plants contains 2000 to 2500 ppm boron.

(3) Primary Water

Treated water which has been deaerated/deoxygenated. This water may contain up to $200 \mathrm{ppb}$ dissolved oxygen. Primary water in PWR plants also contains a borated solution.

(4) Closed Cooling Water

Treated water containing corrosion inhibitors and biocides.

(5) Lubricating Oil

Low to medium viscosity hydrocarbons used for bearing gear and engine lubricating.

(6) Air

The air is the surrounding ambient of various rooms, containment or the drywell. Air-side filters are typically provided to remove particulates from the air stream.

The fluid that circulates through the tubes is usually the most likely to promote fouling (i.e., raw water). It is in contact with the channel nozzles, divider plate, channel and waterbox interior surfaces, and the interior of the tubes. The shell-side fluid is in contact with the tube exterior, the shell internal surfaces, shell nozzles, baffle plates, and tube sheet shell-side surfaces.

The circulating fluid properties described here generally apply to periods when the plant is operating and producing electric power. The internal environmental conditions for heat exchangers when the plant is not in the operating condition (typically $15 \%$ to $30 \%$ of the calendar time) is a function of the plant lay-up program. The environment may be the circulating fluid with changed properties/contaminants, a different fluid, or drained and filled with air. This plant outage environment may affect the degradation rate for aging mechanisms, particularly those which are primarily related to fluid characteristics such as corrosion and stress corrosion cracking, and fouling if outage conditions increase the amount of foreign materials within the fluid system. Since plant lay-up is not within the scope of this AMG, qualification statements made for all determinations of aging mechanism significance assumes that plant outage environments will not increase the rate of degradation from these aging mechanisms during plant operating conditions. The development and implementation of a plant lay-up 
program which ensures that heat exchanger environments are controlled during outage periods is necessary to satisfy these qualifications (see Section 5.3).

\subsubsection{External Environment}

The external surfaces of the shell, waterbox/channel head, piping connections or nozzles, and saddle supports are in contact with the external ambient environment. The heat exchangers are located within buildings. The external environment (excluding primary containment) is filtered ambient building air with temperatures ranging from $4.4^{\circ}$ to $37.8^{\circ} \mathrm{C}\left[40^{\circ}\right.$ to $\left.100^{\circ} \mathrm{F}\right]$ and relative humidities up to $100 \%$. Typical radiation levels in BWR safety-related heat exchanger installations are (cumulative over life of plant) $3 \times 10^{3}$ gray $\left[3 \times 10^{5} \mathrm{rad}\right]$ (normal) and $1 \times 10^{5}$ gray $\left[1 \times 10^{7} \mathrm{rad}\right]$ (accident). For a PWR, these values are $1 \times 10^{4}$ gray $\left[1 \times 10^{6} \mathrm{rad}\right]$ and $1 \times 10^{5}$ gray $\left[1 \times 10^{7} \mathrm{rad}\right]$, respectively [3.8]. All exterior component surfaces are covered with a corrosion resistant coating or made from materials which are resistant to corrosion from the external environment. Each plant's housekeeping maintenance program ensures that exterior coatings are properly maintained.

\subsubsection{Differences in Design}

\section{Shell-and-Tube Heat Exchangers}

Shell-and-U-tube heat exchangers are typically used as letdown, excess letdown, seal water, spent fuel pool, and RHR heat exchangers. The units are usually of the floating tube sheet type construction with the stationary tube sheet welded to the channel and the tubes welded to the tube sheet. The channel cover and the tube bundle can be removed to inspect or clean the tubes. Heat exchanger installation can be horizontal or vertical, with the tube bundle being supported on the baffles, tube support plates or tube sheet.

Multiple shell heat exchangers are usually used as regenerative heat exchangers in the PWR Chemical and Volume Control System (CVCS) and in BWR Reactor Water Cleanup (RWCU) System. In these units, several shell and tube passes are obtained using several horizontal shells (typically three) stacked vertically. Each heat exchanger shell usually has a nonremovable U-tube, tube bundle. These units are of completely welded construction and designed to be self-vented and drained through their piping connections. Permanent leak tightness under conditions of extreme thermal cycling is very important. Shell side inlet and outlet nozzles are typically welded to the shell. The shell is welded to the tube sheet end as well as the shell head end. The tubes are contact rolled prior to welding at each end. After welding, the tubes are rolled the full thickness of the tube sheet. One end of the channel is welded to the tube sheet and the other end is flanged to accept a bolted cover. Removal of the channel cover and seal diaphragm provides access for cleaning tubes and plugging leaky tubes. A welded diaphragm provides sealing of the channel. The support system is designed with one end of the shell welded to a supporting saddle and the other end bolted to provide for shell expansion.

Shell-and-straight-tube heat exchangers are typically used as component cooling heat exchangers, and used in some low flow applications (i.e., lube oil coolers, chillers, etc.). These heat exchangers are of a simple design, construction, and maintenance. They are designed for easy cleaning of the raw water (tube) side. The most common orientation is horizontal. 


\section{Fin-Coil Type Heat Exchangers}

Fin-coil units include a steel housing containing an inlet opening, finned cooling coils, a fan-motor unit, and an air outlet opening. Sometimes air inlets and outlets have louvers to distribute and control air flow, and filters are placed in the inlet side.

The cooling coil water is raw water or closed (treated or chilled) water. Vents and drains are placed in the coil headers to provide a drainable, self-venting coil. Drain pans are located below the coils to drain away the condensate water that results from the air cooling process. The cooling ccils are finned to improve cooling efficiency. The coil headers are brazed to the tubes, or the tubes are hydraulically expanded into die-formed collars in the fins. Lap joint steel stubs and flanges are used for the coil water supply and return connections. The coil tubes can be straight or two tube pass, U-type.

\subsubsection{Description of Predominant Types of Heat Exchangers}

Most of the heat exchangers in nuclear service are either shell and tube in heat transfer between plant systems, or fin-coil type for air cooling.

Tables 3-7 and 3-8 provide typical heat exchanger design and operating parameters for each of the heat exchangers evaluated in this AMG. Tables 3-9 and 3-10 list the manufacturers for these heat exchangers. This information was obtained from the NPRDS database and responses from several utilities.

\subsubsection{Shell-and-Tube Heat Exchangers}

\section{Chemical and Volume Control Regenerative Heat Exchanger — PWR Plants}

The regenerative heat exchanger reduces the temperature of reactor coolant entering the chemical and volume control system. It recovers the heat from the letdown stream by reheating the charging stream during normal operation. The letdown stream can flow through the shell of the regenerative heat exchanger and the charging stream through the tubes or vice versa, as both streams are reactor coolant (borated water). Shell and tubes are made of austenitic stainless steel, and it is an all-welded construction. The unit is typically a multiple tube pass heat exchanger.

\section{Chemical and Volume Control Letdown Heat Exchanger — PWR Plants}

The letdown heat exchanger cools the letdown stream to the operating temperature of the mixed bed demineralizers. Reactor coolant (borated water) flows through the tube side of the exchanger while component cooling water flows through the sheli side. All surfaces in contact with reactor coolant are austenitic stainless steel, and the shell is carbon steel. 


\section{AGING MANAGEMENT GUIDELINE FOR HEAT EXCHANGERS}

\begin{tabular}{|c|c|c|c|c|c|c|c|c|c|c|c|c|}
\hline \multirow[b]{2}{*}{ System and Service } & \multirow[b]{2}{*}{ Type } & \multirow[b]{2}{*}{ Orientation } & \multicolumn{3}{|c|}{$\begin{array}{l}\text { Design Parameter Ranges: } \\
\text { Tube Side }\end{array}$} & \multicolumn{3}{|c|}{$\begin{array}{c}\text { Design Parameter Ranges: } \\
\text { Shell Side } \\
\end{array}$} & \multirow{2}{*}{$\begin{array}{l}\text { Heat Load } \\
\text { W [Btu/hr] }\end{array}$} & \multirow{2}{*}{$\begin{array}{l}\text { Number } \\
\text { of } \\
\text { Tubes }\end{array}$} & \multirow{2}{*}{$\begin{array}{c}\text { Heat } \\
\text { Transfer } \\
\text { Area } \\
\mathbf{m}^{2}\left[\mathrm{ft}^{2}\right]\end{array}$} & \multirow{2}{*}{$\begin{array}{c}\text { Temper- } \\
\text { ature } \\
\text { Rise } \\
{ }^{\circ} \mathrm{C}\left[{ }^{\circ} \mathrm{F}\right]\end{array}$} \\
\hline & & & $\begin{array}{c}\text { Pressure } \\
\text { MPa } \\
\text { [psig] } \\
\end{array}$ & $\begin{array}{l}\text { Temp } \\
{ }^{\circ} \mathrm{C}\left[{ }^{\circ} \mathrm{F}\right] \\
\end{array}$ & $\begin{array}{c}\text { Flow } \\
\mathrm{kg} / \mathrm{sec} \\
{[\mathrm{lbm} / \mathrm{hr}]}\end{array}$ & $\begin{array}{l}\text { Pressure } \\
\text { MPa } \\
\text { [psig] } \\
\end{array}$ & $\begin{array}{l}\text { Temp } \\
{ }^{\circ} \mathrm{C}\left[{ }^{\circ} \mathrm{F}\right] \\
\end{array}$ & $\begin{array}{c}\text { Flow } \\
\mathrm{kg} / \mathrm{sec} \\
{[\mathrm{lbm} / \mathrm{hr}]}\end{array}$ & & & & \\
\hline $\begin{array}{l}\text { Chemical and Volume } \\
\text { Control Excess Letdown } \\
\text { Heat Exchangers }\end{array}$ & $\begin{array}{l}\text { Shell and } \\
\text { U-Tube }\end{array}$ & Horizontal & $\begin{array}{c}17.1 \\
{[2.485]}\end{array}$ & $\begin{array}{c}32-315 \\
{[90-600]}\end{array}$ & $\begin{array}{c}0.6-1.6 \\
{[5 \mathrm{E} 3-} \\
12.5 \mathrm{E} 3]\end{array}$ & $\begin{array}{c}1.0 \\
{[150]}\end{array}$ & $\begin{array}{c}121-177 \\
{[250-350]}\end{array}$ & $\begin{array}{c}6.3-15.1 \\
{[5 E 4-12 E 4]}\end{array}$ & $\begin{array}{c}2.9 \mathrm{E} 5- \\
14.6 \mathrm{E} 5 \\
{[1 \mathrm{E} 6-5 \mathrm{E} 6]} \\
\end{array}$ & 22 & $\begin{array}{l}2.3-6.5 \\
{[25-70]}\end{array}$ & $\begin{array}{c}19.4- \\
22.2 \\
{[35-40]}\end{array}$ \\
\hline $\begin{array}{l}\text { Chemical and Volume } \\
\text { Control Letdown Heat } \\
\text { Exchangers }\end{array}$ & $\begin{array}{l}\text { Shell and } \\
\text { Straight } \\
\text { Tube or } \\
\text { Shell and } \\
\text { U-Tube }\end{array}$ & $\begin{array}{l}\text { Horizontal or } \\
\text { Vertical }\end{array}$ & $\begin{array}{c}1.72-4.1 \\
{[250-600]}\end{array}$ & $\begin{array}{l}27-315 \\
{[80-600]}\end{array}$ & $\begin{array}{c}3.8-7.6 \\
{[3 \mathrm{E}-6 \mathrm{E}-4]}\end{array}$ & $\begin{array}{c}1.0-1.4 \\
{[150-200]}\end{array}$ & $\begin{array}{c}121-177 \\
{[250-350]}\end{array}$ & $\begin{array}{c}21.4-63 \\
{[17 \mathrm{E} 4-50 \mathrm{E} 4]}\end{array}$ & $\begin{array}{l}2.9 \mathrm{E} 5- \\
29.3 \mathrm{E} 5 \\
{[\mathrm{IE} 6-1 \mathrm{E} 7]}\end{array}$ & 108 & $\begin{array}{c}18.6- \\
51.1 \\
{[200-} \\
550]\end{array}$ & $\begin{array}{l}13.9 \\
{[25]}\end{array}$ \\
\hline $\begin{array}{l}\text { Chemical and Volume } \\
\text { Control Regenerative } \\
\text { Heat Exchangers }\end{array}$ & $\begin{array}{l}\text { Multiple } \\
\text { Shell and } \\
\text { U-Tube }\end{array}$ & Horizontal & $\begin{array}{l}17.2-19.3 \\
{[2.500-} \\
2.800]\end{array}$ & $\begin{array}{l}54-316 \\
{[130-} \\
600]\end{array}$ & $\begin{array}{c}2.5-10.1 \\
{[2 \mathrm{E}-8 \mathrm{E} 4]}\end{array}$ & $\begin{array}{c}17.2 \\
{[2500]}\end{array}$ & $\begin{array}{c}54-316 \\
{[130-600]}\end{array}$ & $\begin{array}{c}3.8-5.0 \\
{[3 E-4-4 E 4]}\end{array}$ & $\begin{array}{c}2.9 \mathrm{E} 5- \\
29.3 \mathrm{E} 5 \\
{[1 \mathrm{E} 6-1 \mathrm{E} 7]}\end{array}$ & 40 & $\begin{array}{r}27.9- \\
34.4 \\
{[300-} \\
370] \\
\end{array}$ & $\begin{array}{c}203 \\
{[365]}\end{array}$ \\
\hline $\begin{array}{l}\text { Chemical and Volume } \\
\text { Control Seal Water Heat } \\
\text { Exchangers }\end{array}$ & $\begin{array}{l}\text { Shell and } \\
\text { Straight } \\
\text { Tube or } \\
\text { Shell and } \\
\text { U-Tube } \\
\end{array}$ & $\begin{array}{l}\text { Horizontal or } \\
\text { Vertical }\end{array}$ & $\begin{array}{l}1.0 \\
{[150]}\end{array}$ & $\begin{array}{c}35-121 \\
{[95-250]}\end{array}$ & $\begin{array}{c}10.1-20.2 \\
{[8 E 4-16 \mathrm{E} 4]}\end{array}$ & $\begin{array}{c}1.0 \\
{[150]}\end{array}$ & $\begin{array}{c}49-121 \\
{[120-250]}\end{array}$ & $\begin{array}{c}6.3-13.9 \\
{[5 E 4-11 E 4]}\end{array}$ & $\begin{array}{l}2.9 \mathrm{EE} 5- \\
5.9 \mathrm{E} 5 \\
{[1 \mathrm{E} 6-2 \mathrm{E} 6]}\end{array}$ & 80 & $\begin{array}{c}11.1- \\
34.4 \\
{[120-} \\
370]\end{array}$ & $\begin{array}{l}11.1- \\
22.2 \\
{[20-40]}\end{array}$ \\
\hline $\begin{array}{l}\text { Closed Cooling Water } \\
\text { Heat Exchangers } \\
\text { (Note 1) }\end{array}$ & $\begin{array}{l}\text { Shell and } \\
\text { Straight } \\
\text { Tube }\end{array}$ & Horizontal & $\begin{array}{l}0.7-1.0 \\
{[100-150]}\end{array}$ & $\begin{array}{c}27-93 \\
{[80-200]}\end{array}$ & $\begin{array}{c}157-630 \\
{[12 \mathrm{E} 5-} \\
50 \mathrm{E} 5] \\
\end{array}$ & $\begin{array}{c}0.7-1.4 \\
{[100-200]}\end{array}$ & $\begin{array}{c}27-93 \\
{[80-200]}\end{array}$ & $\begin{array}{c}126-630 \\
{[10 \mathrm{E} 5-50 \mathrm{E} 5]}\end{array}$ & $\begin{array}{c}5.9 \mathrm{E} 6- \\
29.3 \mathrm{E} 6 \\
{[2 \mathrm{E} 7-1 \mathrm{E} 8]} \\
\end{array}$ & $\begin{array}{l}775- \\
2.500\end{array}$ & $\begin{array}{c}622-799 \\
{[6,700-} \\
8,600] \\
\end{array}$ & $\begin{array}{c}3.3-12.2 \\
{[6-22]}\end{array}$ \\
\hline $\begin{array}{l}\text { Containment System Air } \\
\text { Coolers }\end{array}$ & $\begin{array}{l}\text { Fin Coil or } \\
\text { Two Tube } \\
\text { Passes } \\
\end{array}$ & Horizontal & $\begin{array}{l}0.7-1.0 \\
{[100-150]}\end{array}$ & $\begin{array}{c}21-66 \\
{[70-150]}\end{array}$ & $\begin{array}{l}50.4-126 \\
{[4 \mathrm{E} 5-10 \mathrm{E} 5]}\end{array}$ & $\begin{array}{c}0.1-0.3 \\
{[14.7-47]}\end{array}$ & $\begin{array}{c}21-66 \\
{[70-150]}\end{array}$ & $\begin{array}{c}29.3 \\
{[62000 \mathrm{cfm}]}\end{array}$ & $\begin{array}{l}5.9 \mathrm{E} 5 \\
{[2 \mathrm{E} 6]}\end{array}$ & 50 & $\begin{array}{l}5.1 \\
{[55]}\end{array}$ & $\begin{array}{c}2.8-4.4 \\
{[5-8]}\end{array}$ \\
\hline $\begin{array}{l}\text { Emergency Diesel } \\
\text { Generator Jacket Water } \\
\text { Conlers }\end{array}$ & $\begin{array}{l}\text { Shell and } \\
\text { Straight } \\
\text { Tube }\end{array}$ & Horizontal & $\begin{array}{l}: .0 \\
{[150]}\end{array}$ & $\begin{array}{c}27-93 \\
{[80-200]}\end{array}$ & $\begin{array}{l}25.2-44.1 \\
{[20 \mathrm{E} 4-} \\
35 \mathrm{E} 4]\end{array}$ & $\begin{array}{c}1.0 \\
{[150]}\end{array}$ & $\begin{array}{c}27-93 \\
{[80-200]}\end{array}$ & $\begin{array}{c}12.6-40.3 \\
{[10 \mathrm{E}-32 \mathrm{E} 4]}\end{array}$ & $\begin{array}{c}1.2 \mathrm{E} 6- \\
2.6 \mathrm{E} 6 \\
{[4 \mathrm{E} 6-9 \mathrm{E} 6]} \\
\end{array}$ & $300-500$ & $\begin{array}{l}25.5 \\
{[275]}\end{array}$ & $\begin{array}{c}4.40- \\
12.2 \\
{[8-22]}\end{array}$ \\
\hline
\end{tabular}


AGING MANAGEMENT GUIDELINE FOR HEAT EXCHANGERS

\begin{tabular}{|c|c|c|c|c|c|c|c|c|c|c|c|c|}
\hline \multirow[b]{2}{*}{ System and Senice } & \multirow[b]{2}{*}{ Type } & \multirow[b]{2}{*}{ Orientation } & \multicolumn{3}{|c|}{$\begin{array}{l}\text { Design Parameter Ranges: } \\
\text { Tube Side }\end{array}$} & \multicolumn{3}{|c|}{$\begin{array}{l}\text { Design Parameter Ranges: } \\
\text { Shell Side }\end{array}$} & \multirow{2}{*}{$\begin{array}{c}\text { Heat Load } \\
\text { W } \\
{[\text { Btu/hr] }}\end{array}$} & \multirow{2}{*}{$\begin{array}{l}\text { Number } \\
\text { of } \\
\text { Tubes }\end{array}$} & \multirow{2}{*}{$\begin{array}{c}\text { Heat } \\
\text { Transfer } \\
\text { Area } \\
\mathrm{m}^{2}\left[\mathrm{ft}^{2}\right]\end{array}$} & \multirow{2}{*}{$\begin{array}{c}\text { Temper- } \\
\text { ature } \\
\text { Rise } \\
{ }^{\circ} \mathrm{C}\left[{ }^{\circ} \mathrm{F}\right]\end{array}$} \\
\hline & & & $\begin{array}{c}\text { Pressure } \\
\mathrm{MPa} \\
\text { [psig] } \\
\end{array}$ & $\begin{array}{l}\text { Temp } \\
{ }^{\circ} \mathrm{C}\left[{ }^{\circ} \mathrm{F}\right] \\
\end{array}$ & $\begin{array}{c}\text { Flow } \\
\mathrm{kg} / \mathrm{sec} \\
{[\mathrm{lbm} / \mathrm{hr}]}\end{array}$ & $\begin{array}{c}\text { Pressure } \\
\text { MPa } \\
\text { [psig] } \\
\end{array}$ & $\begin{array}{l}\text { Temp } \\
{ }^{\circ} \mathrm{C}\left[{ }^{\circ} \mathrm{F}\right]\end{array}$ & $\begin{array}{c}\text { Flow } \\
\mathrm{kg} / \mathrm{sec} \\
{[\mathrm{lbm} / \mathrm{hr}]}\end{array}$ & & & & \\
\hline $\begin{array}{l}\text { Emergency Diesel } \\
\text { Generator Lubrication } \\
\text { Oul Coolers }\end{array}$ & $\begin{array}{l}\text { Shell and } \\
\text { Straight } \\
\text { Tube }\end{array}$ & Horizontal & $\begin{array}{l}1.0 \\
{[150]}\end{array}$ & $\begin{array}{c}10-121 \\
{[50-250]}\end{array}$ & $\begin{array}{c}94.5-138.6 \\
{[75 E 4-} \\
110 E 4]\end{array}$ & $\begin{array}{l}1.0 \\
{[150]}\end{array}$ & $\begin{array}{c}10-93 \\
{[50-200]}\end{array}$ & $\begin{array}{c}94.5-176.4 \\
{[75 E 4-14 E 5]}\end{array}$ & $\begin{array}{c}2.9 E 5- \\
8.8 E 5 \\
{[1 \mathrm{E} 6-3 \mathrm{EE} 6]} \\
\end{array}$ & 180 & $\begin{array}{c}26 \\
{[280]}\end{array}$ & $\begin{array}{c}2.2-3.3 \\
{[4-6]}\end{array}$ \\
\hline $\begin{array}{l}\text { Miscellaneous Oil } \\
\text { Coolers }\end{array}$ & $\begin{array}{l}\text { Shell and } \\
\text { Straight } \\
\text { rube or } \\
\text { Coils }\end{array}$ & $\begin{array}{l}\text { Horizontal or } \\
\text { Vertical }\end{array}$ & $\begin{array}{l}0.34-1.0 \\
{[50-150]}\end{array}$ & $\begin{array}{c}10-93 \\
{[50-200]}\end{array}$ & $\begin{array}{c}0.9-126 \\
{[7 \mathrm{E} 3-1 \mathrm{E} 6]}\end{array}$ & $\begin{array}{l}0.07-1.0 \\
{[10-150]}\end{array}$ & $\begin{array}{c}38-93 \\
{[100-200]}\end{array}$ & $\begin{array}{c}1.3-190 \\
{[1 \mathrm{E} 4-1.5 \mathrm{E} 6]}\end{array}$ & $\begin{array}{c}2 \mathrm{E} 4- \\
8.8 \mathrm{E} 5 \\
{[7 \mathrm{E} 4-3 \mathrm{E} 6]}\end{array}$ & $20-250$ & $\begin{array}{l}1.4-27.9 \\
{[15-300]}\end{array}$ & $\begin{array}{l}2.8-13.9 \\
{[5-25]}\end{array}$ \\
\hline $\begin{array}{l}\text { Residual Heat Remosal } \\
\text { Heat Exchangers } \\
\text { (Note 2) }\end{array}$ & $\begin{array}{l}\text { Shell and } \\
\text { U-Tube }\end{array}$ & Vertical & $\begin{array}{c}0.7-3.1 \\
{[100-450\}}\end{array}$ & $\begin{array}{l}21-288 \\
{[70-350]}\end{array}$ & $\begin{array}{c}126-252 \\
{[1 \mathrm{E} 6-2 \mathrm{E} 6]}\end{array}$ & $\begin{array}{c}0.7-3.4 \\
{[100-500]}\end{array}$ & $\begin{array}{c}4-38 \\
{[40-100]}\end{array}$ & $\begin{array}{c}164-542 \\
{[13 \mathrm{E} 5-43 \mathrm{E} 5]}\end{array}$ & $\begin{array}{c}8.8 \mathrm{E} 6- \\
8.8 \mathrm{E} 7 \\
{[3 \mathrm{E} 7-3 \mathrm{E} 8]}\end{array}$ & $\begin{array}{l}300- \\
1200\end{array}$ & $\begin{array}{l}210-399 \\
{[2260-} \\
4300]\end{array}$ & $\begin{array}{l}3.3-9.4 \\
{[6-17]}\end{array}$ \\
\hline $\begin{array}{l}\text { Spent Fuel Pool Cooling } \\
\text { Heat Exchangers }\end{array}$ & $\begin{array}{l}\text { Shell and } \\
\text { Straight } \\
\text { Tube or } \\
\text { Shell and } \\
\text { l'-Tube }\end{array}$ & $\begin{array}{l}\text { Horizontal or } \\
\text { Ventical }\end{array}$ & $\begin{array}{c}1.0-14 \\
{[150-200]}\end{array}$ & $\begin{array}{c}27-38 \\
{[80-100]}\end{array}$ & $\begin{array}{c}88-139 \\
{[7 E 5-11 E 5]}\end{array}$ & $\begin{array}{l}1.0-1.4 \\
{[150-200]}\end{array}$ & $\begin{array}{l}27-66 \\
{[80-150]}\end{array}$ & $\begin{array}{l}88-176 \\
{[7 E 5-14 E 5]}\end{array}$ & $\begin{array}{c}2.9 \mathrm{E} 5- \\
2.9 \mathrm{E} 6 \\
{[1 \mathrm{E} 6-1 \mathrm{E} 7]}\end{array}$ & $150-375$ & $\begin{array}{l}74-186 \\
{[800-} \\
2.000]\end{array}$ & $\begin{array}{l}3.3-13.9 \\
{[6-25]}\end{array}$ \\
\hline \multicolumn{13}{|l|}{ Notes: } \\
\hline \multicolumn{13}{|c|}{$\begin{array}{l}\text { 1. Includes various system names. such as component cooling water. emergency equipment cooling water. essential equipment cooling water, and reactor } \\
\text { building closed cooling water. }\end{array}$} \\
\hline
\end{tabular}


AGING MANAGEMENT GUIDELINE FOR HEAT EXCHANGERS

\begin{tabular}{|c|c|c|c|c|c|c|c|c|c|c|c|c|}
\hline \multirow[b]{2}{*}{ System and Service } & \multirow[b]{2}{*}{ Type } & \multirow[b]{2}{*}{ Orientation } & \multicolumn{3}{|c|}{$\begin{array}{c}\text { Design Parameter Ranges: } \\
\text { Tube Side }\end{array}$} & \multicolumn{3}{|c|}{$\begin{array}{l}\text { Design Parameter Ranges: } \\
\text { Shell Side } \\
\end{array}$} & \multirow{2}{*}{$\begin{array}{l}\text { Heat load } \\
\qquad \mathrm{W} \\
{[\mathrm{Btu} / \mathrm{hr}]}\end{array}$} & \multirow{2}{*}{$\begin{array}{l}\text { Number } \\
\text { of Tubes }\end{array}$} & \multirow{2}{*}{$\begin{array}{c}\text { Heat } \\
\text { Transfer } \\
\text { Area } \\
\mathrm{m}^{2}\left[\mathrm{ft}^{2}\right]\end{array}$} & \multirow{2}{*}{$\begin{array}{l}\text { Temper- } \\
\text { ature } \\
\text { Rise } \\
{ }^{\circ} \mathrm{C}\left[{ }^{\circ} \mathrm{F}\right]\end{array}$} \\
\hline & & & $\begin{array}{l}\text { Pressure } \\
\text { MPa [psig] }\end{array}$ & $\begin{array}{c}\text { Temp }{ }^{\circ} \mathrm{C} \\
{\left[{ }^{\circ} \mathrm{F}\right]}\end{array}$ & $\begin{array}{l}\text { Flow kg/sec } \\
{[\mathrm{lbm} / \mathrm{hr}]}\end{array}$ & $\begin{array}{l}\text { Pressure } \\
\text { MPa [psig] }\end{array}$ & $\begin{array}{l}\text { Temp } \\
{ }^{\circ} \mathrm{C}\left[{ }^{\circ} \mathrm{F}\right] \\
\end{array}$ & $\begin{array}{l}\text { Flow } \mathrm{kg} / \mathrm{sec} \\
{[\mathrm{lbm} / \mathrm{hr}]}\end{array}$ & & & & \\
\hline $\begin{array}{l}\text { Closed Cooling Water } \\
\text { Heat Exchangers } \\
\text { (Note 1) }\end{array}$ & $\begin{array}{l}\text { Shell and } \\
\text { Straight } \\
\text { Tube }\end{array}$ & Horizontal & $\begin{array}{c}0.7-1.0 \\
{[100-150]}\end{array}$ & $\begin{array}{c}27-93 \\
{[80-200]}\end{array}$ & $\begin{array}{c}157-630 \\
{[125 \mathrm{E} 4-} \\
500 \mathrm{E} 4]\end{array}$ & $\begin{array}{c}0.7-1.4 \\
{[100-200]}\end{array}$ & $\begin{array}{c}27-93 \\
{[80-200]}\end{array}$ & $\begin{array}{c}126-630 \\
{[100 \mathrm{E} 4-} \\
500 \mathrm{E} 4]\end{array}$ & $\begin{array}{c}5.9 \mathrm{E} 6- \\
29.3 \mathrm{E} 6 \\
{[2 \mathrm{E} 7-} \\
1 \mathrm{E} 8]\end{array}$ & $\begin{array}{l}775- \\
2.500\end{array}$ & $\begin{array}{c}622-799 \\
{[6,700-} \\
8.600]\end{array}$ & $\begin{array}{c}3.3-12.2 \\
{[6-22]}\end{array}$ \\
\hline Drywell Coolers & $\begin{array}{l}\text { Fin Coil. } \\
\text { Two Tube } \\
\text { Passes }\end{array}$ & Horizontal & $\begin{array}{c}0.5-1.0 \\
{[70-150\}}\end{array}$ & $\begin{array}{c}21-66 \\
{[70-150]}\end{array}$ & $\begin{array}{c}21.4 \\
{[17 \mathrm{E} 4]}\end{array}$ & $\begin{array}{l}0.01-0.43 \\
{[14.7-62]}\end{array}$ & $\begin{array}{c}21-66 \\
{[70-150]}\end{array}$ & $\begin{array}{c}5.7-11.8 \\
\mathrm{~m}^{3} / \mathrm{sec} \\
{[1.2 \mathrm{E} 4-} \\
2.5 \mathrm{E} 4 \mathrm{cfm}] \\
\end{array}$ & $\begin{array}{l}1.2 \mathrm{E} 5- \\
2.9 \mathrm{E} 5 \\
{[4 \mathrm{E} 5-} \\
1 \mathrm{E} 6]\end{array}$ & $\begin{array}{l}2 \text { coils } \\
\text { or } \\
75-115 \\
\text { tubes }\end{array}$ & $\begin{array}{l}5.6-8.4 \\
{[60-90]}\end{array}$ & $\begin{array}{c}4.4-19.4 \\
{[8-35]}\end{array}$ \\
\hline $\begin{array}{l}\text { Emergency Core Cooling } \\
\text { System Room Coolers }\end{array}$ & Fin Coil & Horizontal & $\begin{array}{c}0.5-1.0 \\
{[70-150]}\end{array}$ & $\begin{array}{c}21-49 \\
{[70-120]}\end{array}$ & $\begin{array}{c}0.95-6.3 \\
{[7.5 \mathrm{E} 2-5 \mathrm{E} 4]}\end{array}$ & $\begin{array}{c}0.01 \\
{[14.7]}\end{array}$ & $\begin{array}{c}21-49 \\
{[70-120]}\end{array}$ & $\begin{array}{c}0.8-14.2 \\
\mathrm{~m}^{3} / \mathrm{sec} \\
{[1.6 \mathrm{E} 3-} \\
30 \mathrm{E} 3 \mathrm{cfm}] \\
\end{array}$ & $\begin{array}{l}1.5 \mathrm{E} 4- \\
2.3 \mathrm{E} 5 \\
{[5 \mathrm{E} 4-} \\
8 \mathrm{E} 5]\end{array}$ & $\begin{array}{c}2 \text { coils } \\
\text { or } 80- \\
112 \\
\text { tubes }\end{array}$ & $\begin{array}{l}5.8-8.2 \\
{[62-88]}\end{array}$ & $\begin{array}{c}2.8-13.9 \\
{[5-25]}\end{array}$ \\
\hline $\begin{array}{l}\text { Emergency Diesel } \\
\text { Generator Jacket Water } \\
\text { Coolers }\end{array}$ & $\begin{array}{l}\text { Shell and } \\
\text { Straight } \\
\text { Tube }\end{array}$ & Horizontal & $\begin{array}{c}1.0 \\
{[150]}\end{array}$ & $\begin{array}{c}27-93 \\
{[80-200]}\end{array}$ & $\begin{array}{c}25.2-44.1 \\
{[20 \mathrm{E} 4-} \\
35 \mathrm{E} 4]\end{array}$ & $\begin{array}{c}1.0 \\
{[150]}\end{array}$ & $\begin{array}{c}27-93 \\
{[80-200]}\end{array}$ & $\begin{array}{c}12.6-40.3 \\
{[10 \mathrm{E} 4-} \\
32 \mathrm{E} 4]\end{array}$ & $\begin{array}{l}1.2 \mathrm{E} 6- \\
2.6 \mathrm{E} 6 \\
{[4 \mathrm{E} 6-} \\
9 \mathrm{E} 6]\end{array}$ & $300-500$ & $\begin{array}{c}25.5 \\
{[275]}\end{array}$ & $\begin{array}{c}4.4-12.2 \\
{[8-22]}\end{array}$ \\
\hline $\begin{array}{l}\text { Emergency Diesel } \\
\text { Generator Lubrication } \\
\text { Oil Coolers }\end{array}$ & $\begin{array}{l}\text { Shell and } \\
\text { Straight } \\
\text { Tube }\end{array}$ & Horizontal & $\begin{array}{l}1.0 \\
{[150]}\end{array}$ & $\begin{array}{c}10-121 \\
{[50-250]}\end{array}$ & $\begin{array}{c}94.5-138.6 \\
{[75 \mathrm{E} 4-} \\
110 \mathrm{E} 4]\end{array}$ & $\begin{array}{c}1.0 \\
{[150]}\end{array}$ & $\begin{array}{c}10-93 \\
{[50-200]}\end{array}$ & $\begin{array}{c}94.5-176.4 \\
{[75 \mathrm{E} 4-} \\
\text { [40EA] }\end{array}$ & $\begin{array}{l}2.9 \mathrm{E} 5- \\
8.8 \mathrm{E} 5 \\
{[1 \mathrm{E} 6-} \\
3 \mathrm{E} 6]\end{array}$ & 180 & $\begin{array}{c}26 \\
{[280]}\end{array}$ & $\begin{array}{c}2.2-3.3 \\
{[4-6]}\end{array}$ \\
\hline $\begin{array}{l}\text { High Pressure Coolant } \\
\text { Injection Gland Seal } \\
\text { Condensers }\end{array}$ & $\begin{array}{l}\text { Shell and } \\
\text { Straight } \\
\text { Tube }\end{array}$ & Vertical & $\begin{array}{c}1.0 \\
{[150]}\end{array}$ & $\begin{array}{c}93-121 \\
{[200-} \\
250] \\
\end{array}$ & $\begin{array}{c}2.8 \\
{[22.5 \mathrm{E} 3]}\end{array}$ & $\begin{array}{c}0.7 \\
{[100]}\end{array}$ & $\begin{array}{c}4-38 \\
{[40-100]}\end{array}$ & $\begin{array}{c}0.11 \\
{[900]}\end{array}$ & $\begin{array}{l}1.1 \mathrm{E} 5 \\
{[3.7 \mathrm{E} 5]}\end{array}$ & 93 & $\begin{array}{l}8.8 \\
{[95]}\end{array}$ & $\begin{array}{l}5.6-11.1 \\
{[10-20]}\end{array}$ \\
\hline $\begin{array}{l}\text { High Pressure Coolant } \\
\text { Injection Lubrication Oil } \\
\text { Coolers }\end{array}$ & $\begin{array}{l}\text { Shell and } \\
\text { Straight } \\
\text { Tube }\end{array}$ & Horizontal & $\begin{array}{l}0.34 \\
{[50]}\end{array}$ & $\begin{array}{c}4-93 \\
{[40-200]}\end{array}$ & $\begin{array}{c}1.5 \\
{[12 \mathrm{E} 3]}\end{array}$ & $\begin{array}{l}0.07-0.08 \\
{[10-12]}\end{array}$ & $\begin{array}{l}38-93 \\
{[100-} \\
200]\end{array}$ & $\begin{array}{c}3.2 \\
{[25 \mathrm{E} 3]}\end{array}$ & $\begin{array}{l}3.5 \mathrm{E} 4 \\
{[1.2 \mathrm{E} 5]}\end{array}$ & 70 & $\begin{array}{c}6.3 \\
{[68]}\end{array}$ & $\begin{array}{l}11.1 \\
{[20]}\end{array}$ \\
\hline
\end{tabular}


AGING MANAGEMENT GUIDELINE FOR HEAT EXCHANGERS

\begin{tabular}{|c|c|c|c|c|c|c|c|c|c|c|c|c|}
\hline \multirow[b]{2}{*}{ System and Service } & \multirow[b]{2}{*}{ Type } & \multirow[b]{2}{*}{ Orientation } & \multicolumn{3}{|c|}{$\begin{array}{c}\text { Design Parameter Ranges: } \\
\text { Tube Side } \\
\end{array}$} & \multicolumn{3}{|c|}{$\begin{array}{l}\text { Design Parameter Ranges: } \\
\text { Shell Side } \\
\end{array}$} & \multirow{2}{*}{$\begin{array}{l}\text { Heat load } \\
\text { W } \\
{[\mathrm{Btu} / \mathrm{hr}]}\end{array}$} & \multirow{2}{*}{$\begin{array}{l}\text { Number } \\
\text { of Tubes }\end{array}$} & \multirow{2}{*}{$\begin{array}{c}\text { Heat } \\
\text { Transfer } \\
\text { Area } \\
\mathrm{m}^{2}\left[\mathrm{ft}^{2}\right]\end{array}$} & \multirow{2}{*}{$\begin{array}{c}\text { Temper- } \\
\text { ature } \\
\text { Rise } \\
{ }^{\circ} \mathrm{C}\left[{ }^{\circ} \mathrm{F}\right]\end{array}$} \\
\hline & & & $\begin{array}{c}\text { Pressure } \\
\text { MPa [psig] } \\
\end{array}$ & $\begin{array}{c}\text { Temp }{ }^{\circ} \mathrm{C} \\
{\left[{ }^{\circ} \mathrm{F}\right]} \\
\end{array}$ & $\begin{array}{c}\text { Flow } \mathrm{kg} / \mathrm{sec} \\
{[\mathrm{lbm} / \mathrm{hr}]}\end{array}$ & $\begin{array}{c}\text { Pressure } \\
\text { MPa [psig] } \\
\end{array}$ & $\begin{array}{l}\text { Temp } \\
{ }^{\circ} \mathrm{C}\left[{ }^{\circ} \mathrm{F}\right] \\
\end{array}$ & $\begin{array}{c}\text { Flow kg/sec } \\
{[\mathrm{lbm} / \mathrm{hr}]}\end{array}$ & & & & \\
\hline $\begin{array}{l}\text { Miscellaneous Oil } \\
\text { Coulers }\end{array}$ & $\begin{array}{l}\text { Shell and } \\
\text { Straight } \\
\text { Tube or } \\
\text { Coils } \\
\end{array}$ & $\begin{array}{l}\text { Horizontal } \\
\text { or Vertical }\end{array}$ & $\begin{array}{l}0.34-1.0 \\
{[50-150]}\end{array}$ & $\begin{array}{c}4-93 \\
{[40-200]}\end{array}$ & $\begin{array}{c}0.9-126 \\
{[7 E 3-1 E 6]}\end{array}$ & $\begin{array}{l}0.07-1.0 \\
{[10-150]}\end{array}$ & $\begin{array}{l}38-93 \\
{[100-} \\
200]\end{array}$ & $\begin{array}{c}1.3-190 \\
{[1 \mathrm{E} 4-1.5 \mathrm{E} 6]}\end{array}$ & $\begin{array}{l}2 \mathrm{E} 4- \\
8.8 \mathrm{E} 5 \\
17 \mathrm{E} 4- \\
3 \mathrm{E} 6] \\
\end{array}$ & $20-250$ & $\begin{array}{r}1.4-27.9 \\
{[15-300]}\end{array}$ & $\begin{array}{l}2.8-13.9 \\
{[5-25]}\end{array}$ \\
\hline $\begin{array}{l}\text { Reactor Core Isolation } \\
\text { Cooling Lubrication Oil } \\
\text { Coolers }\end{array}$ & $\begin{array}{l}\text { Shell and } \\
\text { Straight } \\
\text { Tube }\end{array}$ & Horizontal & $\begin{array}{l}0.34 \\
{[50]}\end{array}$ & $\begin{array}{c}4-93 \\
{[40-200]}\end{array}$ & $\begin{array}{c}0.9 \\
{[7.2 \mathrm{E} 3]}\end{array}$ & $\begin{array}{l}0.07-0.08 \\
{[10-12]}\end{array}$ & $\begin{array}{l}38-93 \\
{[100-} \\
200] \\
\end{array}$ & $\begin{array}{c}1.7 \\
{[13.5 \mathrm{E} 3]}\end{array}$ & $\begin{array}{l}20.5 \mathrm{E} 3 \\
{[7 \mathrm{E} 4]}\end{array}$ & $20-25$ & $\begin{array}{c}1.8 \\
{[18]}\end{array}$ & $\begin{array}{l}11.1 \\
{[20]}\end{array}$ \\
\hline $\begin{array}{l}\text { Reactor Water Cleanup } \\
\text { Non-Regenerative Heat } \\
\text { Exchangers }\end{array}$ & $\begin{array}{l}\text { Multiple } \\
\text { Shell and } \\
\text { U-Tube }\end{array}$ & Horizontal & $\begin{array}{c}6.8 \\
{[980]}\end{array}$ & $\begin{array}{l}60-110 \\
{[140-} \\
230]\end{array}$ & $\begin{array}{l}19-42 \\
{[1.5 \mathrm{E} 5-} \\
3.3 \mathrm{EE}\}\end{array}$ & $\begin{array}{c}0.7 \\
{[100]}\end{array}$ & $\begin{array}{c}27-93 \\
{[80-200]}\end{array}$ & $\begin{array}{l}12.6-25.2 \\
{[1 \mathrm{E} 5-2 \mathrm{E} 5]}\end{array}$ & $\begin{array}{l}2.9 \mathrm{EE} 6- \\
5.9 \mathrm{E} 6 \\
{[1 \mathrm{E} 7-} \\
\text { 2E7] } \\
\end{array}$ & 55 & $\begin{array}{l}1.37 \\
{[1.470]}\end{array}$ & $\begin{array}{l}32.2 \\
{[58]}\end{array}$ \\
\hline $\begin{array}{l}\text { Reactor Water Cleanup } \\
\text { Regenerative Heat } \\
\text { Exchangers }\end{array}$ & $\begin{array}{l}\text { Multiple } \\
\text { Shell and } \\
\text { U-Tube }\end{array}$ & Horizontal & $\begin{array}{c}6.9 \\
{[1.000]}\end{array}$ & $\begin{array}{l}2+4-293 \\
{[435-} \\
560]\end{array}$ & $\begin{array}{r}19-42 \\
{[1.5 \mathrm{E} 5} \\
3.3 \mathrm{E} 5]\end{array}$ & $\begin{array}{c}8.3 \\
{[1.200]}\end{array}$ & $\begin{array}{l}224-293 \\
{[435-} \\
560]\end{array}$ & $\begin{array}{r}19-42 \\
{[1.5 \mathrm{E} 5-} \\
3.3 \mathrm{E} 5]\end{array}$ & $\begin{array}{c}8.8 \mathrm{E} 6- \\
14.6 \mathrm{E} 6 \\
{[3 \mathrm{E} 7-} \\
5 \mathrm{E} 7] \\
\end{array}$ & 90 & $\begin{array}{c}164 \\
{[1.760]}\end{array}$ & $\begin{array}{l}111.7 \\
{[201]}\end{array}$ \\
\hline $\begin{array}{l}\text { Residual Heat Removal } \\
\text { Heat Exchangers } \\
\text { (Note } 2)\end{array}$ & $\begin{array}{l}\text { Shell and } \\
\text { L-Tube }\end{array}$ & Vertical & $\begin{array}{c}2.8-4.1 \\
{[400-600]}\end{array}$ & $\begin{array}{l}38-177 \\
{[100-} \\
350]\end{array}$ & $\begin{array}{c}126-252 \\
{[1 \mathrm{E} 6-2 \mathrm{E} 6]}\end{array}$ & $\begin{array}{c}0.7-3.4 \\
{[100-500]}\end{array}$ & $\begin{array}{c}4-38 \\
{[40-100]}\end{array}$ & $\begin{array}{l}164-542 \\
{[13 \mathrm{E} 5-} \\
43 \mathrm{E} 5]\end{array}$ & $\begin{array}{l}8.8 \mathrm{E} 6- \\
8.8 \mathrm{E} 7 \\
{[3 \mathrm{E} 7-} \\
3 \mathrm{E} 8] \\
\end{array}$ & $\begin{array}{l}300- \\
1200\end{array}$ & $\begin{array}{l}210-399 \\
{[2.260-} \\
4.300]\end{array}$ & $\begin{array}{l}3.3-9.4 \\
{[6-17]}\end{array}$ \\
\hline $\begin{array}{l}\text { Spent Fuel Pool Cooling } \\
\text { Heat Exchangers }\end{array}$ & $\begin{array}{l}\text { Shell and } \\
\text { Straight } \\
\text { Tube or } \\
\text { Shell and } \\
\text { U-Tube }\end{array}$ & $\begin{array}{l}\text { Horizontal } \\
\text { or Vertical }\end{array}$ & $\begin{array}{l}1.0-1.4 \\
{[150-200]}\end{array}$ & $\begin{array}{c}27-38 \\
{[80-100]}\end{array}$ & $\begin{array}{c}88-139 \\
{[7 E 5-11 E 5]}\end{array}$ & $\begin{array}{c}1.0-1.4 \\
{[150-200]}\end{array}$ & $\begin{array}{c}27-66 \\
{[80-150]}\end{array}$ & $\begin{array}{c}88-176 \\
{[7 E 5-14 E 5]}\end{array}$ & $\begin{array}{l}2.9 \mathrm{E} 5- \\
2.9 \mathrm{E} 6 \\
{[1 \mathrm{E} 6-} \\
\text { [E7] }\end{array}$ & $150-375$ & $\begin{array}{l}74-186 \\
{[800-} \\
2.000]\end{array}$ & $\begin{array}{c}3.3-13.9 \\
{[6-25]}\end{array}$ \\
\hline \multicolumn{13}{|c|}{$\begin{array}{l}\text { Notes: } \\
\text { 1. Includes various system names. such as component cooling water. emergency equipment cooling water. essential equipment cooling water, and reactor } \\
\text { building closed cooling water. } \\
\text { 2. Includes various system names. such as decay heat removal. low pressure coolant injection. shutdown cooling, and containment cooling. }\end{array}$} \\
\hline
\end{tabular}


AGING MANAGEMENT GUIDELINE FOR HEAT EXCHANGERS

\begin{tabular}{|c|c|c|c|c|c|c|c|c|c|}
\hline $\begin{array}{l}\text { Chemical and } \\
\text { Volume Control } \\
\text { Letdown and } \\
\text { Excess Letdown }\end{array}$ & $\begin{array}{l}\text { Chemical and } \\
\text { Volume Control } \\
\text { Regenerative }\end{array}$ & $\begin{array}{l}\text { Chemical and } \\
\text { Volume Control } \\
\text { Seal Water }\end{array}$ & $\begin{array}{c}\text { Closed } \\
\text { Cooling Water }\end{array}$ & $\begin{array}{l}\text { Containment } \\
\text { Air Cooling }\end{array}$ & $\begin{array}{c}\text { Emergency } \\
\text { Core Cooling } \\
\text { Room Coolers }\end{array}$ & $\begin{array}{c}\text { Emergency Diesel } \\
\text { Generator Jacket } \\
\text { Water and Lube } \\
\text { Oil Cooling }\end{array}$ & $\begin{array}{c}\text { Diesel } \\
\text { Generator } \\
\text { Lube Oil }\end{array}$ & $\begin{array}{c}\text { Residual } \\
\text { Heat Removal }\end{array}$ & $\begin{array}{c}\text { Spent } \\
\text { Fuel Pool }\end{array}$ \\
\hline \multirow{2}{*}{$\begin{array}{l}\text { Graham } \\
\text { Atlas Industrial }\end{array}$} & Sentry Equipment & Atlas Industrial & Struthers Wells & $\begin{array}{l}\text { American Air } \\
\text { Filter }\end{array}$ & Carrier & $\begin{array}{l}\text { American } \\
\text { Standard. Inc. }\end{array}$ & $\begin{array}{l}\text { Fairbanks } \\
\text { Morse Engine }\end{array}$ & $\begin{array}{l}\text { Dresser } \\
\text { Industrial }\end{array}$ & \multirow{13}{*}{$\begin{array}{l}\text { Oat. Joseph } \\
\text { Atlas Industrial }\end{array}$} \\
\hline & $\begin{array}{l}\text { Westinghouse/ } \\
\text { Hagan }\end{array}$ & $\begin{array}{l}\text { Westinghouse/ } \\
\text { Hagan }\end{array}$ & Delta Southern & Westinghouse/ & $\begin{array}{l}\text { American } \\
\text { Standard. Inc. }\end{array}$ & Basco & American & & \\
\hline \multirow{11}{*}{$\begin{array}{l}\text { Oat. Joseph } \\
\text { Westinghouse/ } \\
\text { Hagan } \\
\text { Sentry Equipment }\end{array}$} & & & Standard. Inc. & Joy & & & ITT Standard & & \\
\hline & & & Graham & Marlo Coil & & Thermxchanger & Electro-Motive/ & $\begin{array}{l}\text { Engrneers and } \\
\text { Fabricators }\end{array}$ & \\
\hline & & & & Nuclear Cooling & & Graham & General Motors & & \\
\hline & & & $\begin{array}{l}\text { Engineers and } \\
\text { Fabricators }\end{array}$ & & & EC Cooley & & & \\
\hline & & & Foster Wheeler & & & Westinghouse & & & \\
\hline & & & $\begin{array}{l}\text { Worthington/ } \\
\text { McGraw-Edison }\end{array}$ & & & & & & \\
\hline & & & $\begin{array}{l}\text { Marlow } \\
\text { Industries }\end{array}$ & & & & & & \\
\hline & & & Atlas Industrial & & & & & & \\
\hline & & & Vogt. Henry & & & & & & \\
\hline & & & $\begin{array}{l}\text { Westinghousd } \\
\text { Hagan }\end{array}$ & & & & & & \\
\hline & & & Oat. Joseph & & & & & & \\
\hline
\end{tabular}




\section{AGING MANAGEMENT GUIDELINE FOR HEAT EXCHANGERS}

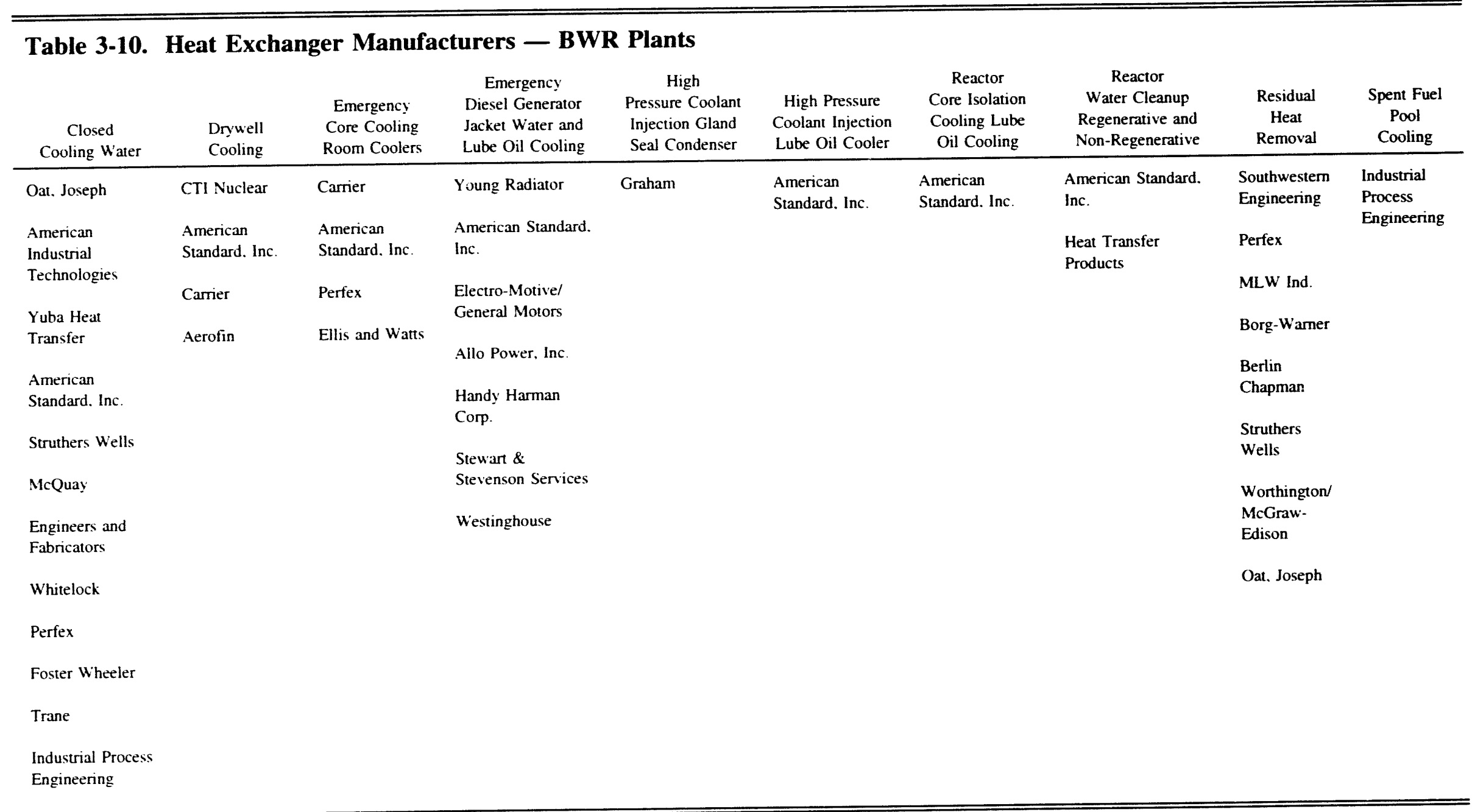




\section{Chemical and Volume Control Excess Letdown Heat Exchanger - PWR Plants}

The excess letdown heat exchanger cools reactor coolant during reactor start-up, when there is insufficient charging flow to absorb the heat in the regenerative heat exchanger. The letdown stream (borated water) flows through the tube side and component cooling water is circulated through the shell side. All surfaces in contact with reactor coolant are austenitic stainless steel and the shell is carbon steel. All tube joints are welded.

\section{Chemical and Volume Control Seal Water Heat Exchanger - PWR Plants}

The seal water heat exchanger removes heat from the reactor coolant pump seal water returning to the volume control tank and reactor coolant discharge from the excess letuown heat exchanger. Reactor coolant (borated water) flows through the tubes and component cooling water is circulated through the shell side. The tubes are welded to the tube sheet to prevent leakage in either direction. All surfaces in contact with reactor coolant are austenitic stainless steel and the shell is carbon steel.

\section{Reactor Water Cleanup Regenerative and Non-Regenerative - BWR Plants}

The cleanup heat exchangers cool reactor water prior to entering the cleanup demineralizers and then reheat the water by passage through the shell side of the regenerative heat exchanger. Reactor water (primary water) is circulated through the tubes of the regenerative heat exchanger and the tubes of the non-regenerative heat exchanger prior to entering the cleanup demineralizers. Treated water is circulated through the shell of the non-regenerative heat exchanger for cooling. After leaving the demineralizers, the reactor water is circulated through the shell of the regenerative heat exchanger. The regenerative heat exchanger tubes and shell are austenitic stainless steel. The non-regenerative heat exchanger has austenitic stainless steel tubes and carbon steel shell.

\section{HPCI Gland Seal Condenser - BWR Plants}

Steam from the high-pressure coolant injection (HPCI) turbine gland seals and valve leakoffs is directed to the gland seal condenser, which prevents radioactive steam from leaking to the atmosphere. Condenser cooling water is supplied from the HPCl booster pump, which takes suction from either the condensate storage tank or the suppression pool. Condensed water is collected in the hotwell. It is usually a shell-and-straight-tube heat exchanger, and the cooling water flows through the tubes while primary steam/water mixture flows through the shell side. The tubes are usually stainless steel and the shell is carbon steel.

\section{HPCI Lubrication Oil Heat Exchanger - BWR Plants}

The oil cooler is a heat exchanger that receives cooling water from the HPCI booster pump. The cooling water flows through the tube side and the lube oil flows through the shell side. It is typically a shell-and-straight-tube, horizontal heat exchanger. The tubes can be made of admiralty or stainless steel, and the shell is usually carbon steel. 


\section{RCIC Lubrication Oil Cooler - BWR Plants}

The reactor core isolation cooling ( $\mathrm{RCIC)}$ ) turbine lubricating oil is circulated through an oil cooler before being routed to the bearings and governor. Cooling treated water flows through the tube side while the lube oil flows through the shell side. The tubes can be made of admiralty or stainless steel and the shell is usually carbon steel.

\section{Spent Fuel Pool Heat Exchanger - PWR and BWR Plants}

The Spent Fuel Pool Cooling System is designed to remove heat generated by stored spent fuel elements from the spent fuel pool. Pool water circulates through the tubes of the heat exchanger. Closed cooling water cools the heat exchanger. The purity of the spent fuel pool water is maintained by passing part of the system flow through a filter and demineralizer. The heat exchangers are usually of the shell-and-U-tube type, with the tubes welded to the tube sheet. The tubes are austenitic stainless steel and the shell is carbon steel.

\section{Component Cooling Water Heat Exchangers - PWR and BWR Plants}

Two or three component cooling water heat exchangers are provided to cool the discharge of the component cooling water pumps before circulating the water through the system. Closed cooling water (demineralized water) flows through the shell side and service water (raw water) flows through the tube side of the heat exchanger. The tube-to-tube sheet joint is usually rolled and welded and the tubes can be stainless steel, admiralty, $90-10 \mathrm{Cu}-\mathrm{Ni}$, or aluminum-brass. The shell is usually made of carbon steel.

\section{RHR Heat Exchangers - PWR and BWR Plants}

The residual heat removal (RHR) heat exchangers are designed to remove decay heat and residual heat from the reactor coolant pressure boundary so that refueling and primary system servicing can be performed. They also provide cooling for the suppression pool water (BWRs only), and provide for containment/spray cooling. In addition, the RHR heat exchangers supplement spent fuel pool cooling capacity when necessary to provide additional cooling. There are two, vertical, shell-and-U-tube type heat exchangers. Raw water flows through the tube side while treated or primary water flows through the shell side. The tubes are made of austenitic stainless steel, with welded tube-to-tube sheet joints, and the shell can be carbon steel with stainless overlay.

\section{Emergency Diesel Generator (EDG) Jacket Water Coolers - PWR and BWR Plants}

The diesel engine is cooled by demineralized or treated water. The water circulates through the jackets and air aftercoolers. This heated water flows through the shell side of the heat exchangers. Water from the plant service water system flows through the tubes. The tubes can be admiralty or other copper alloy, while the shell is usually carbon steel. 


\section{EDG Lubrication Oil Coolers - PWR and BWR Plants}

The EDG lube oil cooler is cooled by the EDG jacket water that flows from the heat exchangers. The cooler absorbs heat from the lube oil to maintain proper operating oil temperature. A common type of heat exchanger is shell-and-straight-tube, with the lube oil flowing through the shell.

\subsubsection{Fin-Coil Type Heat Exchangers}

\section{Containment Air Coolers - PWR Plants}

There are usually four fan-coil units, any three of which will provide heat removal capacity from the reactor containment during full-power operation, to maintain air temperature below the maximum temperature allowable at any component, and to obtain temperatures below a set limit in accessible areas during hot standby operation. The heat sink for the fan-coils is provided by the closed cooling water system, service water system, or the containment chilled water system. Each fan-coil unit consists of a four-sided arrangement of horizontal tube, vertical plate-fin cooling coils, motors, and fans.

\section{Drywell Coolers - BWR Plants}

From four to eight fan-coil units, depending on the plant design, maintain the drywell atmosphere at the required average temperature, and reduce the air temperature after shutdown. The coolers circulate cooled air or nitrogen around critical drywell equipment. Each cooling coil is supplied by the closed cooling water system. Often the coils have two tube passes. The tubes are typically made of copper, while the fins are made of aluminum.

\section{Emergency Core Cooling Room Coolers - PWR and BWR Plants}

Air cooling units provide cooling for the Emergency Core Cooling System (ECCS) pump motors. ECCS pump room coolers are used to maintain room ambient air temperatures within acceptable limits for the pump motors [3.9]. The ECCS room coolers are fan-coil units. The air flows across the cooling coils, where it is cooled, and continues then into a fan that returns it to the room. The air is usually filtered. The cooling coil water is either raw water or closed cooling water. The cooling coils are finned. The coil are usually copper or copper-nickel $(\mathrm{Cu}-\mathrm{Ni})$, while the fins are usually aluminum, copper, or $90-10 \mathrm{Cu}-\mathrm{Ni}$.

\subsection{Design Requirements}

The design requirements for heat exchangers in nuclear service have evolved since the early 1960s. For nuclear applications prior to 1965, the ASME Boiler and Pressure Vessel (B\&PV) Code, Section VIII, "Unfired Pressure Vessels Built by Welding" was cited for the pressure boundary. Following issuance of the 1965 ASME B\&PV Code, Section III "Nuclear Vessels," heat exchanger pressure boundaries were designed to either Quality Group A, B, or C requirements. 
Until 1977, the focus of the ASME B\&PV Code was on the design, fabrication, construction, and testing of the pressure retaining boundary (shell and tubes). The 1977 code further defined the design boundary to include structural internals, integral support elements, and other components. Design requirements specified in later editions of ASME Section III have not been substantially modified.

Nuclear plant owners are responsible for applying system safety criteria to classify components in nuclear power plants to be constructed according to ASME codes. Classification is included in design specifications. Construction rules are specified for items which are designated Code Classes 1, 2, 3, CS, MC, CB, and CC. These Code classes are intended to be applied to the classification of items of nuclear power systems. Within these systems, the Code recognizes the different levels of importance associated with the function of each item as related to the safe operation of the nuclear power plant. The Code classes allow a choice of rules that provide assurance of structural integrity and quality commensurate with the relative importance assigned to the individual items. All of the heat exchangers evaluated in this AMG are designed in accordance with the ASME B\&PV Code. The safety-related heat exchangers' primary (reactor coolant) sides are designed using the ASME Section III Code. The secondary side (cooling water side) is designed using ASME Section VIII Code criteria.

Code Class 2 and 3 heat exchangers are constructed in accordance with the rules of ASME Section III Subsections NC and ND, respectively.

A quality classification system for safety-related components containing water, steam, or radioactive material in water-cooled nuclear power plants was established by the NRC. The system consists of four quality groups, $A$ through $D$, methods for assigning components to these quality groups, and the specific quality standards applicable to each group. Quality Group A is assigned to reactor coolant pressure boundary components and is described in 50.2 and 50.55a of 10 CFR 50. Regulatory Guide 1.26 describes methods for determining acceptable quality standards for the remaining safety-related components containing radioactive material, water, or steam (i.e., Quality Group B, C, and D components). The heat exchangers evaluated in this AMG are primarily Quality Group B and C. The diesel generator heat exchangers, depending on plant vintage, may be designed to Quality Group D criteria. In some cases, the diesel heat exchangers were supplied by the diesel manufacturer, and no specific code requirements were applicable. In these cases, the heat exchangers were evaluated by the utility to ensure the design adequately met the intent of existing design criteria.

The Quality Group B and C heat exchangers are designed to ASME B\&PV Code, Section III, Class 2 and Class 3 requirements, respectively. Room coolers are generally built to meet the quality assurance requirements of 10 CFR 50 Appendix B or ANSI N45.2 or NQA-1/ NQA-2 for the time period 1986 to present. The design standard for room cooler cooling coils is the ARI 410 Standard for Forced Circulation Air-Cooling and Air-Heating Coils, issued by the Air Conditioning and Refrigeration Institute. Most heat exchangers are designed in accordance with the ASME Code, Section III, Class 2 or 3 requirements and are "N" stamped.

The ASME B\&PV Code has strict rules regarding the wall thicknesses of all pressure containing parts, material quality assurance provisions, weld joint design, radiographic and liquid 
penetrant examination of materials and joints, and hydrostatic testing of the unit as well as requiring final inspection and stamping of the vessel by an ASME Code inspector.

The heat exchanger designs must also conform to the requirements of the Tubular Exchanger Manufacturers Association (TEMA) for Class $\mathbf{R}$ and Class $\mathbf{C}$ heat exchangers. Class $R$ is the most rugged class of TEMA heat exchangers and is intended for units where safety and durability are required under severe service conditions. For example, tube spacing, flange design, nozzle location, baffle thickness and spacing, and impingement plate requirements are set forth by TEMA Standards.

In addition to the above, additional design and inspection requirements are often imposed to ensure rugged, high quality heat exchangers. The design and inspection requirements include:

- Confined-type gaskets.

- Main flange studs with two nuts on each end to ensure permanent leak tightness.

- General construction and mounting brackets suitable for the plant seismic design requirements.

- Tubes and tube sheet capable of withstanding full shell side pressure and temperature with atmospheric pressure on the tube side.

- Ultrasonic inspection of all tubes before bending in accordance with Paragraph N-324.3 of the ASME Code Section III.

- Penetrant inspection of all welds and hot or cold formed parts, in accordance with Paragraph N-627 of the ASME Code Section III.

- A hydrostatic test duration of not less than 30 minutes.

- The witnessing of hydro and penetrant tests by a qualified inspector.

- A thorough final inspection of the unit for good workmanship and the absence of any gouge marks or other scars that could act as stress concentration points.

- A review of the radiographs in accordance with ASME Section III, Subsection NC, Article NC-5000 and Section V Article 2 (Non-Destructive Examination) and of the certified chemical and physical test reports for all materials used in the unit.

The heat exchanger designs are based on analytical and laboratory test results and historical performance. Formal stress and fatigue calculations in accordance with the ASME B\&PV Code are performed for all pressure boundary components. Selection of materials for all elements is based on the service application, environmental data, and expected duty.

The resistance of heat exchanger components to various aging mechanisms is determined to some extent by the properties of the metals selected. Metallurgical processes that occur over 
long periods of time will often change the molecular structure and chemistry of the material in localized areas which may reduce the resistance to further aging. Metallurgical dealloying processes are usually those pertinent to the materials selected for heat exchangers in these applications. An rxample is dezincification for brass materials (see Section 4). These processes are known to occur in aqueous environments, but they are as dependent on the original material chemistry/forming processes and calendar time as they are the environment. These metallurgical changes to materials usually originate at the exterior surface where they affect resistance to corrosion, erosion, fatigue, and wear.

\subsubsection{Compliance with Standard Review Plan}

NUREG-0800 [3.10] establishes the format and content requirements of the safety analysis reports prepared for nuclear plants during design and construction. NUREG-0800 does not require the licensee to specifically address the provisions for detection and mitigation of aging. Overall, the review of NUREG-0800 did not identify any criteria related to heat exchanger aging beyond the requirements for testability. Accessibility for testing ensures a method of detecting degradation.

NUREG-1299 [3.11] focuses on the license renewal requirements in 10 CFR 54. The format and content of the integrated plant assessment, to be prepared in support of license renewal application, is described. The primary purpose of the assessment is to determine the effectiveness of plant programs to detect and mitigate age-related degradation of SSCs. This document identifies each system which may be important to license renewal and is intended to be used by the NRC staff during performance of safety reviews of applications for renewal of nuclear power licenses. It provides the framework to ensure that (among other things) the application identifies SSCs that are important to license renewal, significant age-related degradation has been identified and evaluated, and programs to manage aging are or will be implemented.

NUREG-1299 discusses aging of heat exchangers that are important to license renewal. Typical aging age-related degradation mechanisms that could affect the operation and safety of the heat exchangers in the systems are identified. This document was reviewed to ensure that the AMG considers the identified aging mechanisms and programs for management of heat exchanger aging. Sections 4 and 5 of this AMG include the evaluations and conclusions of heat exchanger aging and aging management. Where applicable, additional aging mechanisms and aging management programs identified in industry documents and lead plant license renewal studies are discussed.

\subsubsection{Application and Qualification of Non-Metallic Materials and Sacrificial Anodes}

The non-metallic parts of a heat exchanger are basically the gaskets. They are required to maintain a passive function preventing leakage. Gaskets are used in flanged joints, such as between shell cover-end flange, or shell channel-end flange. Gaskets are typically fully retained on all sides by metallic surfaces, protecting them from direct radiation exposure. A gasket failure results in leakage. 
Qualification of other non-metallic materials is best handled by design review of materials in contact with the heat exchanger fluids and the environment. Elevated temperatures affect degradation of non-metallics such as oil and elastomers. These materials require controlled operating temperatures to function properly. As a rule, non-metallic materials can be qualified by surveillance tests when operating temperatures and transient/accident temperatures are nearly the same. If higher transient or accident temperatures are anticipated, then a material evaluation needs to be performed.

The general threshold for radiation damage of non-metallic materials is $10^{3}$ gray $\left[10^{5} \mathrm{rad}\right]$. However, for asbestos and carbon-based materials, the threshold is $10^{7}$ gray $\left[10^{9}\right.$ rad $]$ or greater [3.8].

Tables 3-11 and 3-12 list published information on allowable temperatures and radiation exposure for some common non-metallic materials used in heat exchangers. The radiation doses are based on studies of elastomer-based electrical insulation and jacket combinations [3.8]. The materials listed in Tables $3-11$ and $3-12$ all have serviceable radiation levels of $5 \times 10^{4}$ gray $\left[5 \times 10^{6} \mathrm{rad}\right]$ or greater. This suggests that a specific review for non-metallic material qualification is appropriate only for mechanical components located in the high potential radiation zones. A threshold for all organic materials (except Teflon which is reported as $1.5 \times 10^{2}$ gray $\left[1.5 \times 10^{4} \mathrm{rad}\right]$ ) has been reported as $10^{3}$ gray $\left[10^{5} \mathrm{rad}\right][3.8]$. These facts suggest the following guidelines [3.8].

Table 3-11. Non-Metallic Material Allowable Temperature and Radiation Exposures

\begin{tabular}{|c|c|c|c|}
\hline Popular Name & Chemical Designation & $\begin{array}{c}\text { Serviceable Radiation Level } \\
\text { gray [rad] }\end{array}$ & $\begin{array}{l}\text { Max Continuous Temperature } \\
\qquad{ }^{\circ} \mathrm{C}\left[{ }^{\circ} \mathrm{F}\right]\end{array}$ \\
\hline Butyl GRI & Isobutylene-Isoprene & $5 \times 10^{4}\left[5 \times 10^{6}\right]$ & $8.5|185|$ \\
\hline Neoprene GRM & Chloroprene & $\left.5 \times 10^{5} \mid 5 \times 10^{7}\right\}$ & $93[200 \mid$ \\
\hline Buna & Butadiene & $5 \times 10^{4}\left[5 \times 10^{6}\right\}$ & $|04| 220 \mid$ \\
\hline EPR & Ethylene Propylene & $1 \times 10^{6}\left|1 \times 10^{8}\right|$ & $149|300|$ \\
\hline $\begin{array}{l}\text { Fluoroelastomer } \\
\text { (Viton) }\end{array}$ & $\begin{array}{l}\text { Vinylidene fluoride + } \\
\text { hexafluoro-propylene }\end{array}$ & $5 \times 10^{5}\left[5 \times 10^{7}\right\}$ & $204|400|$ \\
\hline Teflon (TFE) & Fluoroethylene & $1.7 \times 10^{2}\left\{1.7 \times 10^{4}\right\}$ & $260|5(0)|$ \\
\hline Nylon & Polyamide & $4.7 \times 10^{4}\left|4.7 \times 10^{6}\right|$ & $149[300)]$ \\
\hline Tefzel & Fluoropolymer & $5 \times 10^{5}\left[5 \times 10^{7}\right]$ & $150|302|$ \\
\hline
\end{tabular}

Note: Serviceable radiation level is intended to he an order of magnitude screening value to indicate the relative importance of radiation, as compared with other aging factors such as temperature and wear, in the overall evaluation of environmental qualification.

* Per Reference 3.8 
Table 3-12. Non-Metallic Material Radiation Data

\begin{tabular}{ccc} 
Material & Radiation gray [rad] & Trade Name \\
\hline $\begin{array}{c}\text { Gaskets } \\
\text { Asbestos \& Steel Elastomer }\end{array}$ & $10^{7}\left[10^{9}\right]$ & Flexitallic \\
\hline
\end{tabular}

1. Organic Materials. Conduct an analysis or test only if the radiation dose is $>10^{2}$ gray $\left[>10^{4} \mathrm{rad}\right]$ or if the equipment contains no teflon and radiation doses are greater than $10^{3}$ gray $\left[10^{5} \mathrm{rad}\right]$.

2. Graphite and Asbestos Materials. Waive further design review if the only nonmetallic materials used in the equipment are graphite or asbestos based.

3. Sacrificial Anodes. Sacrificial anodes are used to protect heat exchanger components in contact with fresh or sea water against corrosion. The structure to be protected (tubes and/or shell) is made the cathode in a galvanic corrosion cell, and current is supplied by the corrosion of anodes that are commonly made of zinc or magnesium.

The sacrificial anode in a cathodic protection system should be checked periodically and replaced as required. The greater the corrosion potential, the more frequent the inspections should be scheduled.

\subsection{Operating and Service History}

A review of industry data and documents was conducted to determine the industry-wide operating experience of the heat exchangers evaluated in this AMG. The types of documents reviewed were:

a. NRC LER database

b. INPO NPRDS

c. NRC Bulletins, Information Notices, Generic Letters, and Circulars

d. Plant Operating and Service Data

A summary of the reviews of ach of the above documents is discussed in this section. Section 3.6.1 contains the LER database review and conclusions and Section 3.6.2 summarizes the NPRDS review.

A list of the NRC Bulletins, Notices, Generic Letters, and Circulars applicable to the heat exchangers evaluated in this AMG is included in Table 3-13. These docurnents identify heat exchanger/system degradation that is also contained in the LER and NPRDS information.

Plant operating and service data was received from several utilities in response to a questionnaire on heat exchanger types, design parameters, and maintenance history. The heat exchanger failure/degradation identified in these responses is also either included or in basic agreement with the aging mechanisms identified in the LER and NPRDS information. For this 
Table 3-13. List of NRC Information Notices, Bulletins, Circulars, and Generic Letters Related to Heat Exchanger Degradation

INFORMATION NOTICES

IN 81-21 Potential Loss of Direct Access to Ultimate Heat Sink

IN 83-56 Operability of Required Auxiliary Equipment

IN 84-71 Graphitic Corrosion of Cast Iron in Salt Water

IN 85-24 Failures of Protective Coatings in Pipes and Heat Exchangers

IN 85-30 Microbiologically Induced Corrosion of Containment Service Water System

IN 85-33 Undersized Nozzle-to-Shell Welded Joints in Tanks and Heat Exchangers Constructed Under the Rules of the ASME Boiler and Pressure Vessel Code

IN 85-56 Inadequate Environment Control for Components and Systems in Extended Storage or Lay-Up

IN 86-96 Heat Exchanger Fouling Can Cause Inadequate Operability of Service Water Systems

IN 88-37 Flow Blockage of Cooling Water to Safety System Components

IN 9()-26 Inadequate Flow of Essential Service Water to Room Coolers and Heat Exchangers for Engineered Safety-Feature Systems

IN 90-80 Sand Intrusion Resulting in Two Diesel Generators Becoming Inoperable

\section{IE BULLETINS}

BL 80-24 Prevention of Damage Due to Water Leakage Inside Containment

BL 81-03 Flow Blockage of Cooling Water to Safety System Components by Corbicula SP. (Asiatic Clam) and Mytilus SP. (Mussel)

IE CIRCULARS

C 80-07 Problems With HPCI Turbine Oil System

GENERIC LETTERS

GL 89-13 Service Water System Problems Affecting Safety-Related Equipment

reason, the LER and NPRDS discussions adequately cover plant operating experiences and separate discussion is not necessary.

\subsubsection{Licensee Event Report Evaluation}

LERs are submitted to the NRC by nuclear power plant operators for a number of reasons. Some of the reasons which are applicable to heat exchangers evaluated in this AMG include:

- Any operation or condition prohibited by the plants' technical specifications.

- Any event or condition that results in the condition of the nuclear power plant, including its principal safety barrier, being seriously degraded. 
- Any event where a single cause or condition caused at least one independent train to become inoperable in multiple systems or two independent trains to become inoperable in a single system.

A key word search of heat exchanger failures/degradations was performed on the LER database for the period from 1980 through June 1992. The sort of LERs was further categorized to those incidents where heat exchanger failures/degradations were potentially caused by aging mechanisms. The categories are:

- Heat exchanger failures which were due to age/wear/end-of-life, fatigue or vibration

- Heat exchanger failures due to corrosion, erosion, condensation, or high humidity/ steam

- Heat exchanger failures due to foreign material, aquatic organisms, inadequate lubrication, or radiation exposure

- Heat exchanger failures due to high or low temperatures

- Heat exchanger failures for the years 1980-1992 (1980 was used as a start date because of possible inconsistent reporting before that time.)

The results of this data search yielded 302 total LER abstracts dealing with heat exchanger failures/degradation. A review of these abstracts was performed to segregate those heat exchangers included in the scope of this AMG and where aging was identified as the primary cause of the heat exchanger failure/degradation. The results of this review show that $42.1 \%$ (127) of the LERs are associated with heat exchangers included in the scope of this AMG and where failure/degradation was most likely caused by some form of aging.

Of the 302 LER abstracts, $57.9 \%$ (i.e., 175) were omitted from consideration in this AMG. Those LERs omitted fell into one of the following five categories:

- Situations where the primary cause of heat exchanger failure/degradation was clearly due to something other than aging. For example, design error, procedure deficiency, inadequate or improperly performed maintenance, personnel error, etc.

- The heat exchanger is not in the scope of this AMG. For example, main unit condenser, feedwater heaters, sampling coolers, ice condensers, etc.

- Situations where heat exchanger failure was caused by an aging failure/degradation of a supporting piece of equipment such as a control valve, instrumentation, etc.

- Situations where the heat exchangers covered in the database is a PWR steam generator. Degradation/failure of PWR steam generators is evaluated extensively in other industry related documentation. 
- Situations where heat exchanger failure was due to gasket failure. Gaskets are renewable items and should be replaced at regularly scheduled intervals (see Section 3.4.2).

Several conclusions can be drawn from analysis of this LER data. Figure 3-5 shows the relative percentage of the various aging mechanisms causing heat exchanger failure/degradation. Fouling is the predominant aging mechanism $(44.1 \%)$ that causes heat exchanger failure/ degradation. Erosion/corrosion and corrosion (general, galvanic, and pitting) rank number two $(25.2 \%)$ and three $(12.6 \%)$ respectively. Other aging mechanisms are fatigue $(5.5 \%)$ and one case of wear. Unknown causes accounted for $11.8 \%$ of the heat exchanger failures.

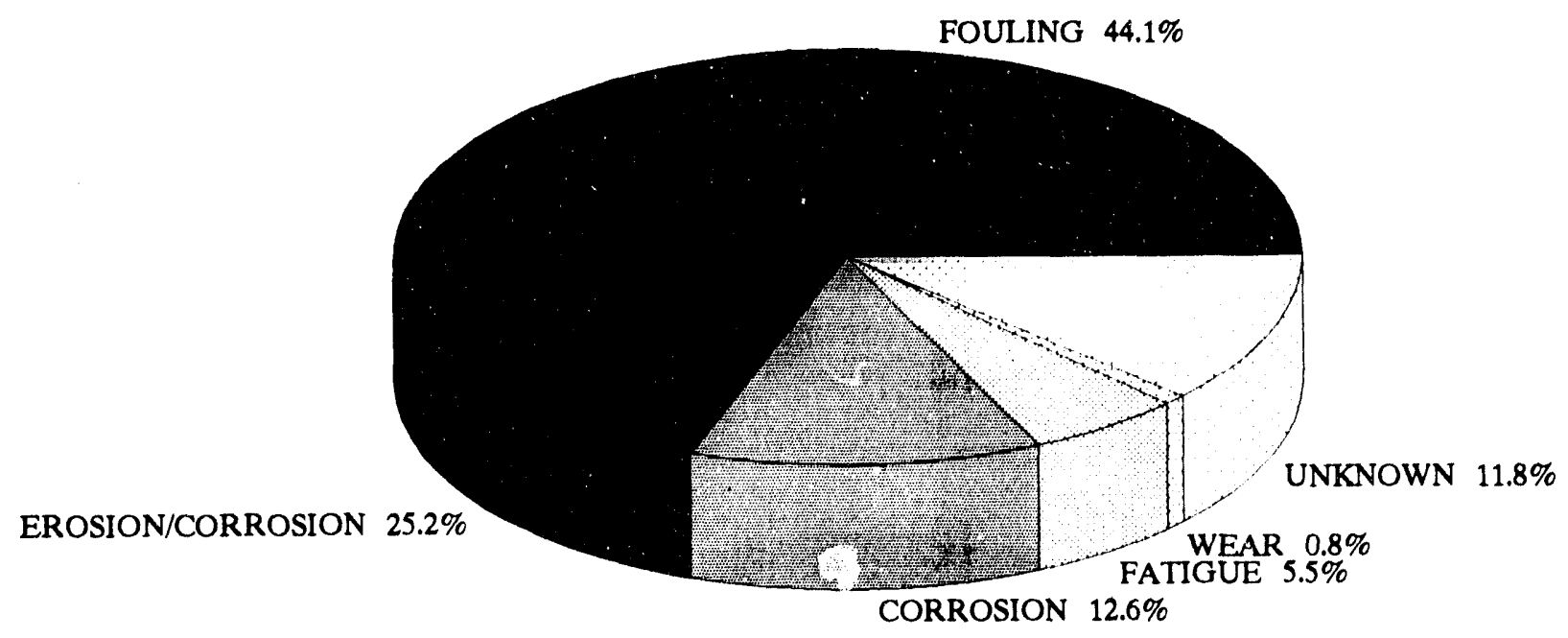

Figure 3-5. Heat Exchanger Failures and Aging Causes.

Fouling, erosion/corrosion, and corrosion, account for an overwhelming majority of the total heat exchanger failures/degradations, particularly when considering the types of heat exchangers experiencing the most failures. In BWRs, the RHR heat exchangers account for $38.8 \%$ of the failures, followed by the component cooling water heat exchangers $(30.6 \%)$, the EDG jacket water heat exchangers (13.9\%), and the various building room coolers $(11.1 \%)$. Figure 3-6 shows the relative percentages of all the BWR heat exchanger failures due to aging. In PWRs, the containment air coolers account for $38.4 \%$ of the failures, followed by the Component Cooling Water (CCW) heat exchangers $(29.7 \%)$, and various building room coolers (14.3\%). Figure 3-7 shows the relative percentages of all PWR heat exchanger failures due to aging.

Further examination was conducted to distinguish the various sources/causes of heat exchanger fouling. The sources/causes were segregated into one of four categories:

- Marine biofouling (mussels, clams, shells, etc.)

- Particulate fouling (sediment, silt, dust, corrosion products, etc.) 


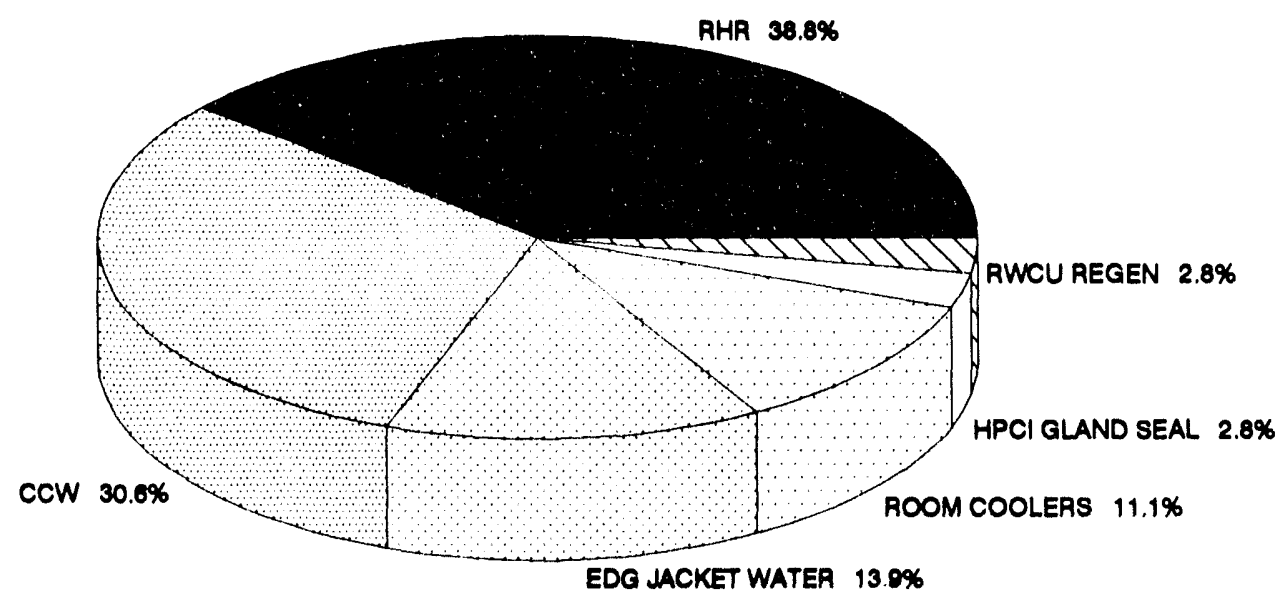

Figure 3-6. BWR Heat Exchanger Aging Failures LER Database 1980-1992.

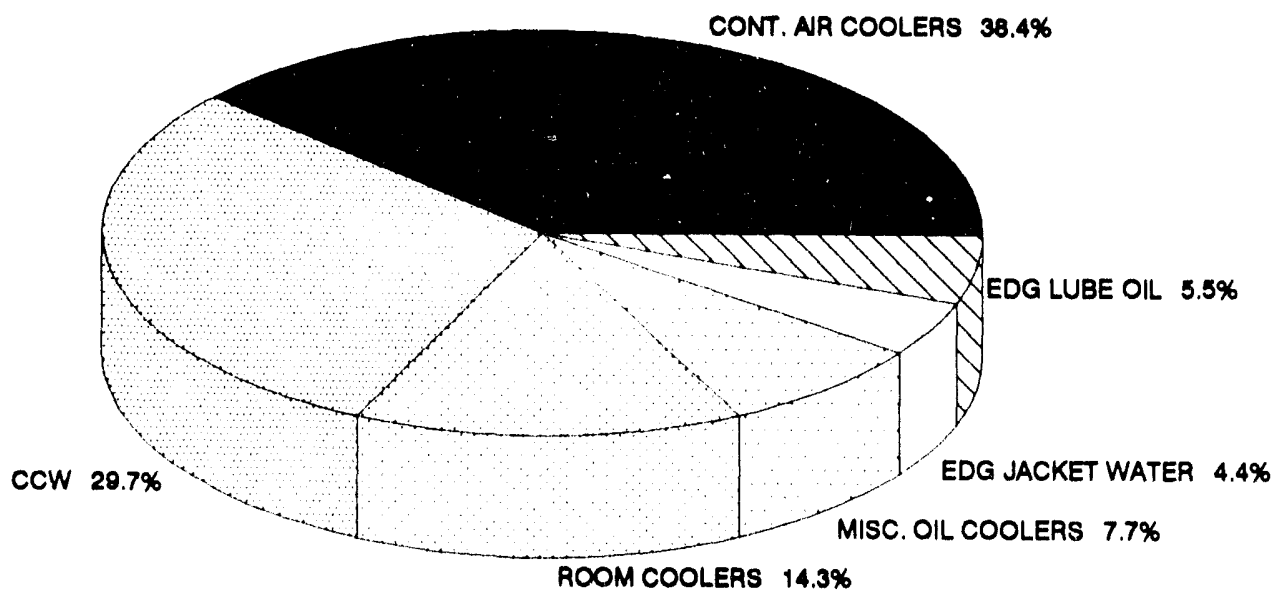

Figure 3-7. PWR Heat Exchanger Aging Failures LER Database 1980-1992.

- Macro fouling (peeled coatings, debris, etc.)

- Unknown causes of fouling

Marine biofouling accounted for $41.1 \%$ of the heat exchanger failures, followed by particulate fouling $(25.0 \%)$ and macro fouling $(8.9 \%)$. The type of heat exchanger fouling could not be distinguished in $25.0 \%$ of the cases.

The analysis of failures was further expanded to include a review of the heat exchanger subcomponents which experienced aging. Table 3-14 lists the subcomponents which were identified as the primary reason for heat exchanger aging. The tubes, as expected exhibited the greatest number of failures, being susceptible to fouling, erosion, corrosion, and fatigue. 


\section{Table 3-14. Heat Exchanger Subcomponent Failures Due to Aging - LER Database}

\begin{tabular}{llc} 
Subcomponent & Number of Failures Due to Aging & Percent of Total \\
\hline Tubes & 106 & 83.4 \\
Waterbox (Note 1) & 10 & 7.9 \\
Tube Sheet & 6 & 4.7 \\
Baffles/Supports & 3 & 2.4 \\
Shell (Note 2) & 2 & 1.6 \\
\hline Notes: & & \\
1. The subcomponent waterbox includes waterbox, channel head, end bell, and flanges. \\
2. The subcomponent shell includes shell, internals, and nozzles.
\end{tabular}

\subsubsection{Nuclear Plant Reliability Data System Evaluation}

The NPRDS was developed in 1973 to collect data on safety-related equipment. Since then, NPRDS scope has been expanded to include other systems and components that provide critical safety functions and whose loss of function can initiate a significant transient. Utilities submit component failure records whenever an NPRDS-reportable component fails to perform one or more of its intended functions [3.12]. Reporting of failures is a voluntary industry effort and, therefore, there are many variations in interpretation of reportability requirements and contents and consistency of reports. Per INPO-89-014, United States nuclear utilities have demonstrated their support of NPRDS by dedicating resources to report all reportable failures that have occurred since January 1, 1984, or when the plant begins commercial operation. Previous to that date, the LER was widely used for reporting failures.

A key word search of heat exchanger failures/degradations was performed on NPRDS for the period of 1974 through May 1992. A total of 2,768 records involving heat exchangers was identified. A review of these records was performed to identify those records where heat exchanger failure/degradation was potentially caused by aging mechanisms for the heat exchangers included in the scope of this AMG. This review reduced the number of incidents to 664 or $24 \%$ of all heat exchanger failures reported. Thus, 2,104 NPRDS reported incidences (76\%) were omitted from consideration in this AMG. NPRDS reports were omitted for the same reasons as those stated in Section 3.6.1 for the LER data.

- Situations where the primary cause of heat exchanger failure/degradation was clearly due to something other than aging. For example, design error, procedure deficiency, inadequate or improperly performed maintenance, personnel error. etc.

- The particular heat exchanger is not in the scope of this AMG. For example, main unit condenser, feedwater heaters, sampling coolers, ice condensers, etc.

- Situations where heat exchanger failure was caused by an aging failure/degradation of a supporting piece of equipment such as a control valve, instrumentation, etc. 
- Situations where the heat exchanger in the NPRDS is a PWR steam generator. Degradation/failure of PWR steam generators is evaluated extensively in other industry related documentation.

- Situations where the heat exchanger failure was caused by gasket leaks. These subcomponents are considered renewable (see Section 3.4.2).

Figure 3-8 shows the number of NPRDS-reported heat exchanger failures due to aging degradation and the number of plants in commercial operation. The trend shows a significant increase starting in 1984 and continuing to present. Although it may be coincidental, this increase in aging failures occurred at the same time that NPRDS reporting was given a higher priority by utilities and the NPRDS data system was given more emphasis in the industry. The increase was especially evident in PWR component cooling water heat exchangers, and BWR RHR heat exchangers and reactor building closed cooling water (RBCCW) heat exchangers.

Figures 3-9 and 3-10 illustrate the number of NPRDS-reported heat exchanger failures by plant type. A comparison of these graphs indicate that the observed increase failure reporting was similar for both PWRs and BWRs. These graphs also illustrate that the reporting increase was independent of the number of heat exchangers in service. In other words, the failure reporting increase did not appear to be due to a significant increase in the number of heat exchangers.

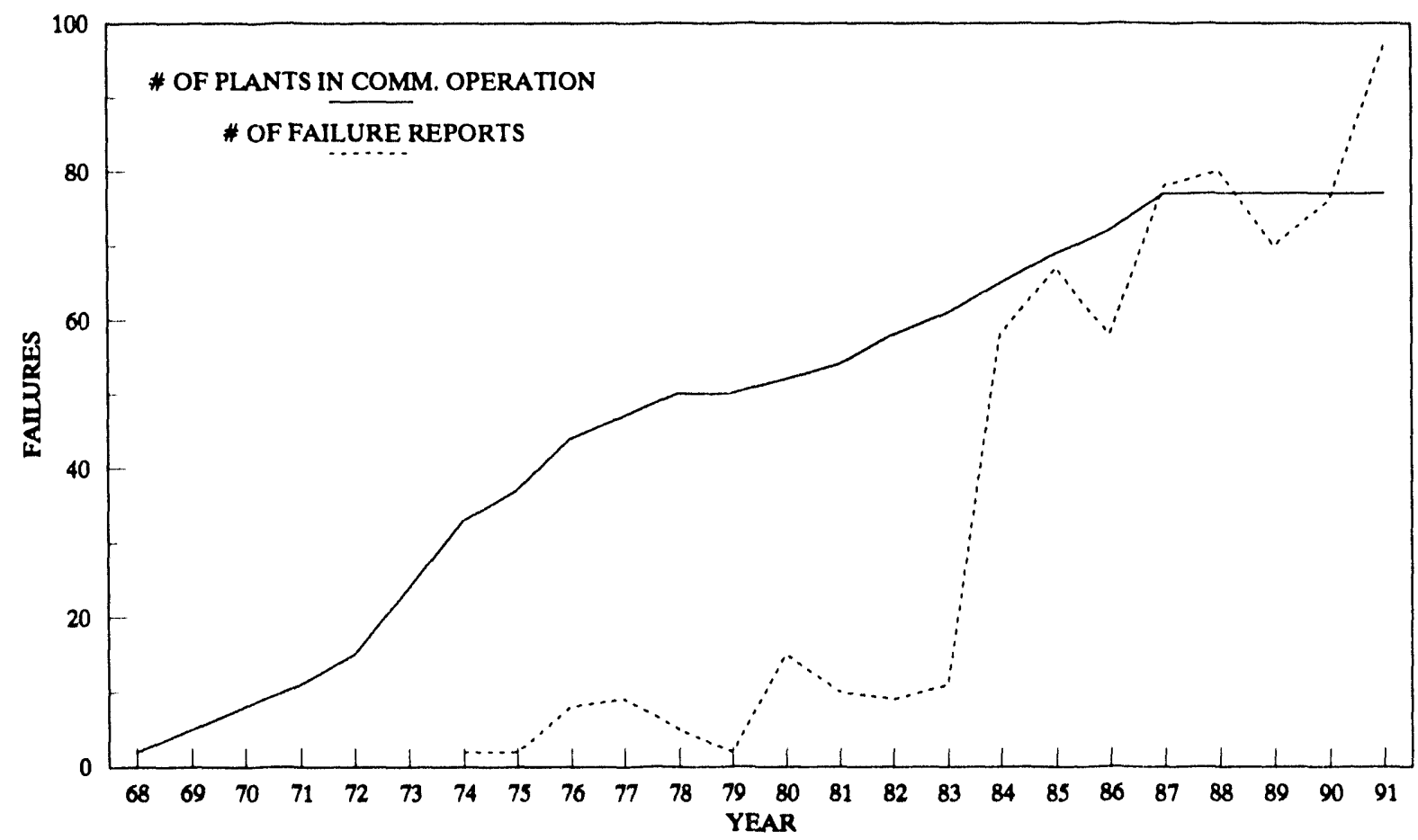

Figure 3-8. Heat Exchanger Aging Failures NPRDS Database. 


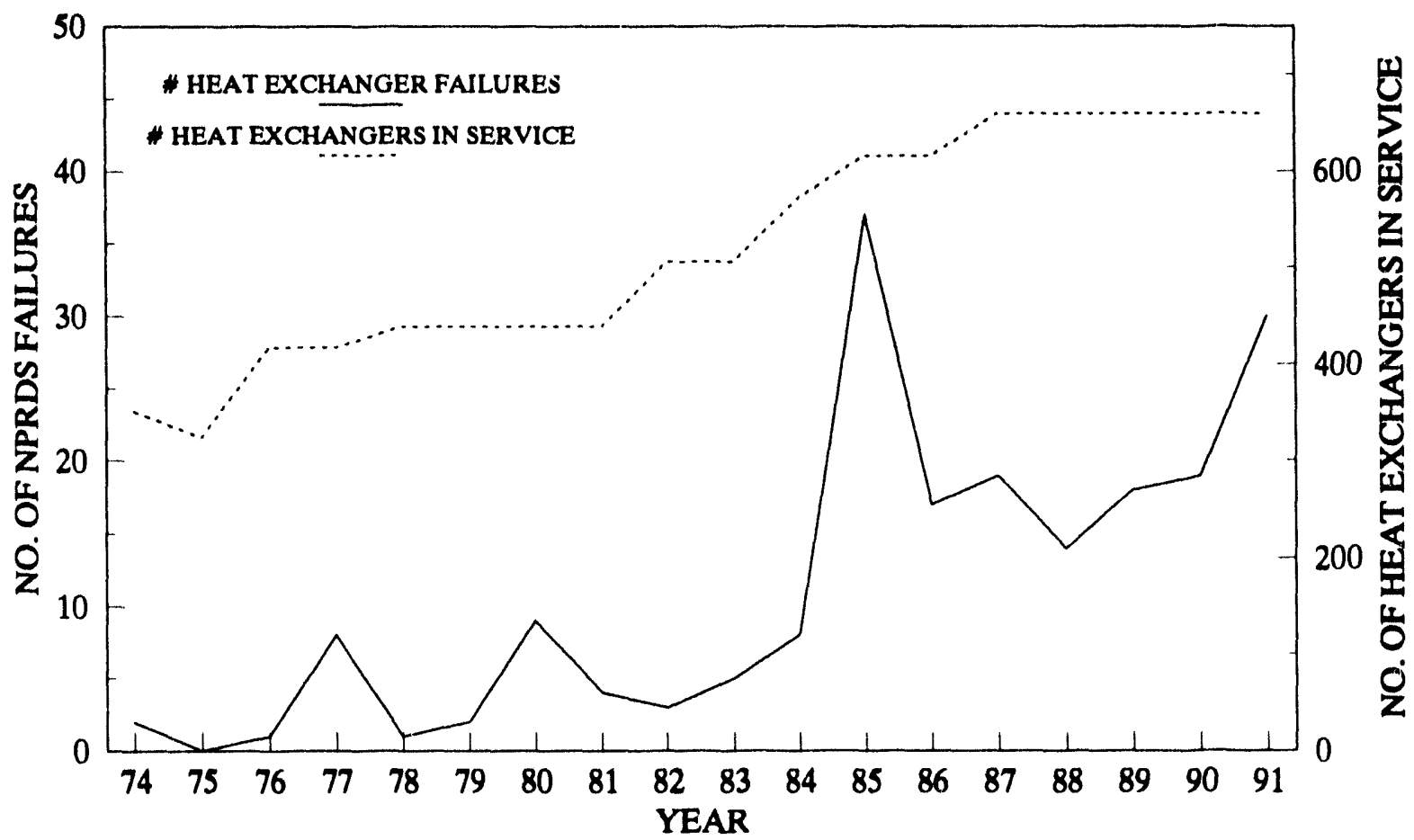

Figure 3-9. BWR Heat Exchanger Aging Failures.

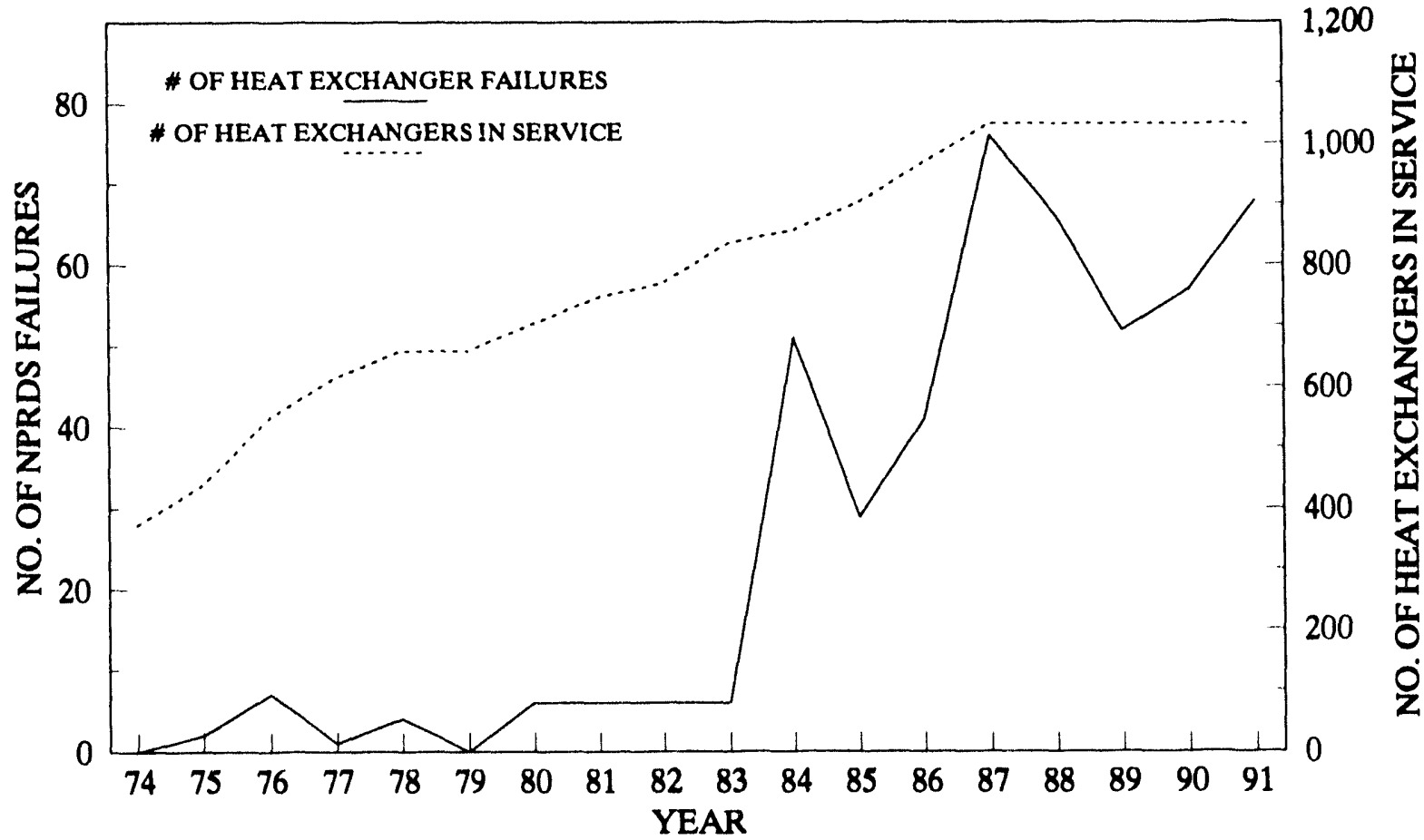

Figure 3-10. PWR Heat Exchanger Aging Failures. 
The failures reported were separated by plant and heat exchanger type. Figure 3-11 depicts the number of failures of BWR heat exchangers. The RHR heat exchangers account for $44 \%$ of the age-related failures, followed by the $\mathrm{CCW}$ heat exchangers which account for $32.2 \%$ and the EDG cooling water heat exchangers which account for $17.7 \%$ of the age-related failures.

Figure 3-12 shows the distribution of PWR heat exchanger failures. The component cooling water heat exchangers account for 55\% of the age-related failures, followed by the containment air coolers (13.6\%), and the EDG cooling water heat exchangers which account for $10 \%$ of the age-related failures.

Several conclusions can be drawn from analysis of NPRDS data. Figure 3-13 shows the relative percentage of the various aging mechanisms causing heat exchanger failure/degradation. Fouling is the predominant aging mechanism. Fouling accounted for over $31 \%$ of the failures reported, and it includes marine growth, silt, debris, foreign material, and sand. Corrosion (16.8\%) was the second most common aging mechanism, followed by wear (10.9\%), erosion/corrosion $(5.9 \%)$, erosion $(5.1 \%)$, and MIC (3.5\%). The failures for which the cause reported was "wear" should probably fall under the category erosion or E/C. If these three mechanisms are considered as one, the percentage of failures caused by erosion, erosion/corrosion or "wear" would be almost $22 \%$. Other degradation mechanisms causing failures were fatigue (3\%), vibration $(2.9 \%)$, pitting (1.8\%), galvanic corrosion $(1.0 \%)$, and SCC $(0.9 \%)$. The rest were either unknown or defined with terms such as "stress" or "age."

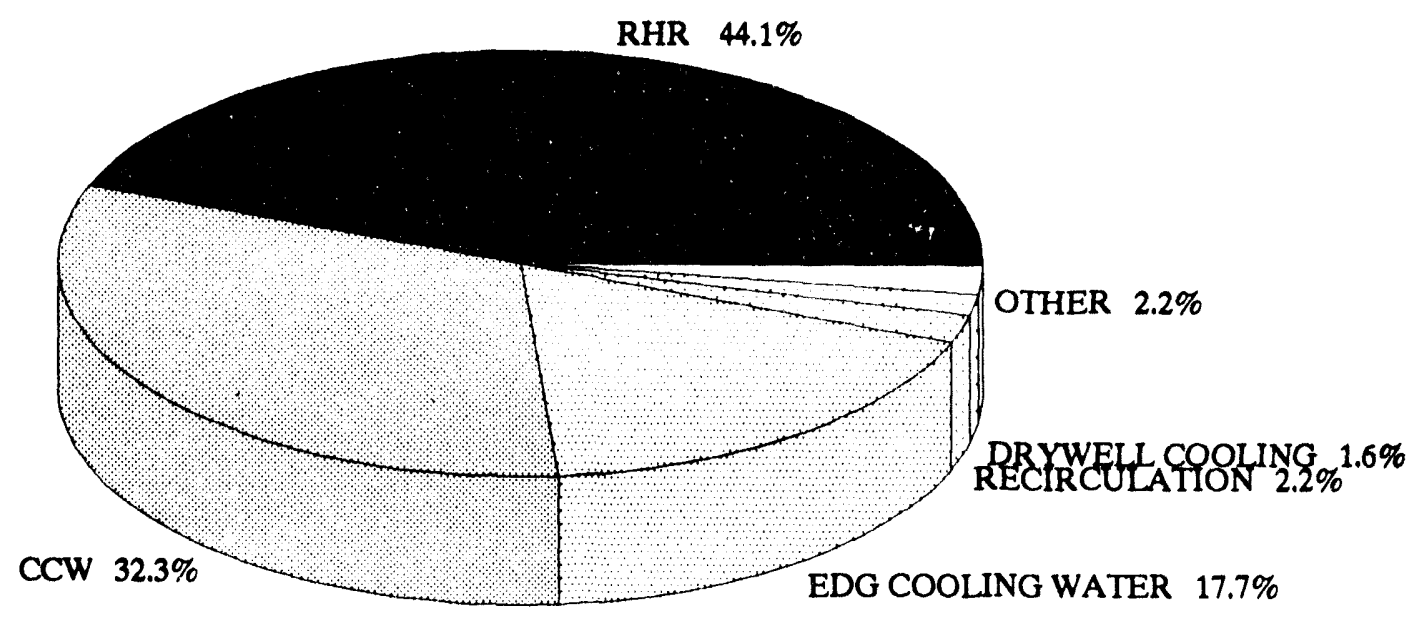

Figure 3-11. Heat Exchanger Type Failures BWR Plants. 
COMP. COOLING WATER $55.0 \%$

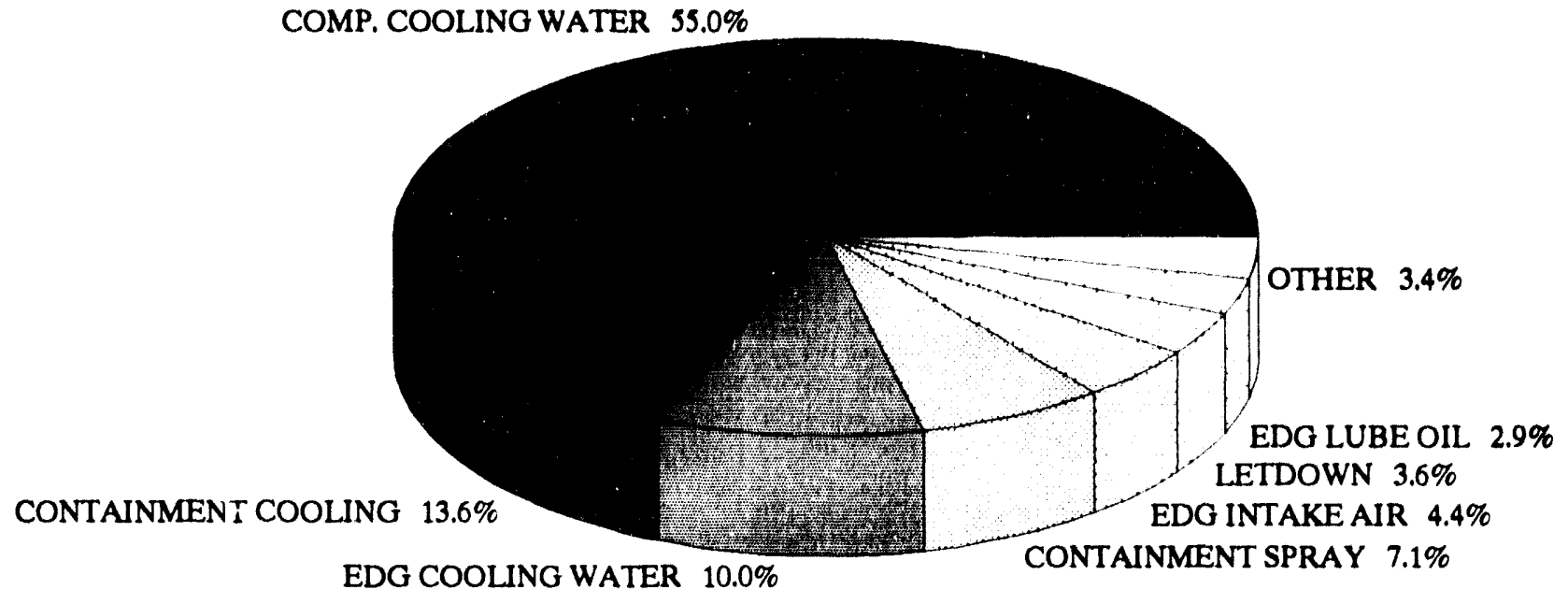

Figure 3-12. Heat Exchanger Type Failures PWR Plants.

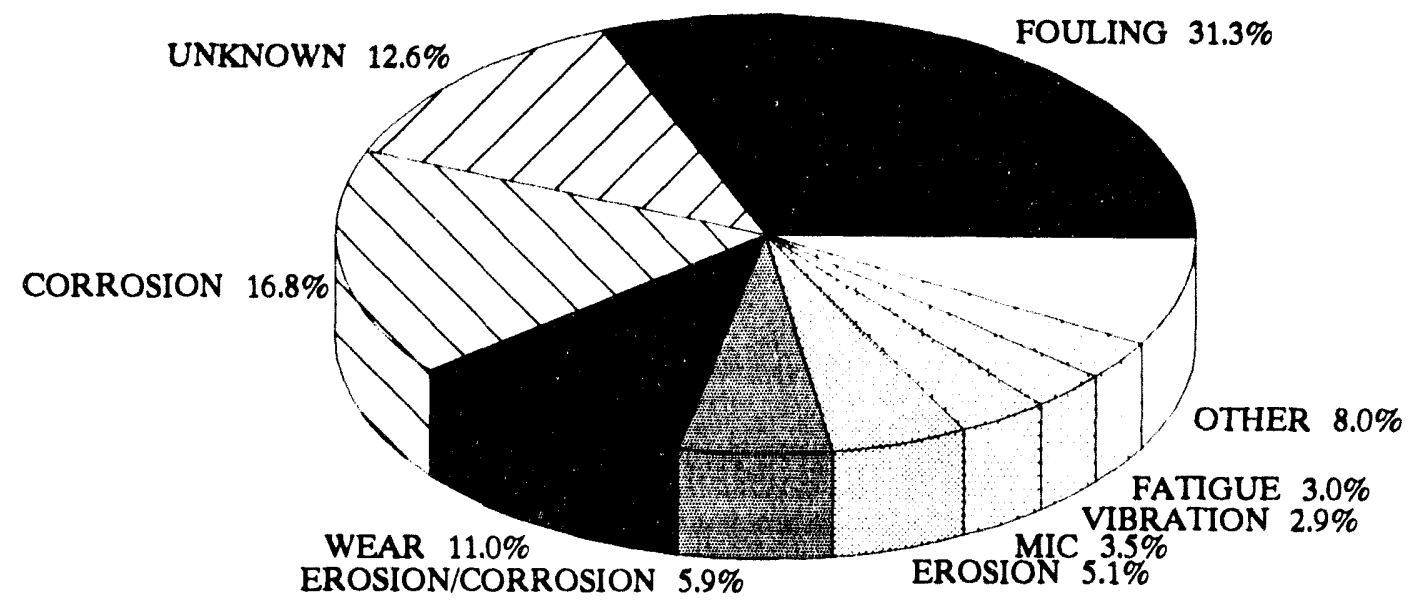

Figure 3-13. Heat Exchanger Failures and Aging Causes NPRDS Data. 
There were no failure reports identifying the following aging mechanisms:

- IASCC

- TGSCC

- Neutron Embrittlement

- Thermal Embrittlement

- Creep

- Stress Relaxation

The analysis of failures was further expanded to include a review of the heat exchanger subcomponents which experienced aging. Table 3-15 lists the subcomponents that were identified as the primary reason for heat exchanger aging. The tubes exhibit the highest number of failures, being susceptible to fouling, erosion, corrosion and fatigue. The shell internals, coils, and tube sheet also have high percentages of failures, mostly due to fouling.

Although NPRDS reporting is a voluntary industry effort, U.S. nuclear utilities have demonstrated their support by dedicating resources to report all reportable failures that have occurred since January 1, 1984, or after the date of commercial operation, whichever date is

\section{Table 3-15. Heat Exchanger Subcomponent Failures Due to Aging - NPRDS Database 1974-1992}

\begin{tabular}{lcc}
\multicolumn{1}{c}{ Subcomponent } & Number of Failures Due to Aging & Percent of Total \\
\hline Tubes & 402 & 60.3 \\
Shell (Note 1) & 62 & 9.3 \\
Tube Sheet & 56 & 8.4 \\
Coil & 56 & 8.4 \\
Waterbox (Note 2) & 50 & 7.5 \\
Baffle Plate & 12 & 1.8 \\
Fasteners & 6 & 0.9 \\
Coating & 5 & 0.8 \\
Floating Head & 5 & 0.8 \\
Divider Plate & 5 & 0.8 \\
Sacrificial Anodes & 3 & 0.5 \\
Heat Exchanger (Note 3) & 3 & 0.5 \\
$\quad$ TOTAL & 665 & $100 \%$ \\
\hline Notes: & \\
1. The subcomponent shell includes shell, internals, and nozzles. \\
2. The subcomponent waterbox includes waterbox, channel head, end bell, and flanges. \\
3. The NPRDS report only listed the heat exchanger as the subcomponent. These failures may actually \\
include any one or more of the other subcomponents. \\
\hline \hline
\end{tabular}




\section{AGING MANAGEMENT GUIDELINE FOR HEAT EXCHANGERS}

latest. However, the reporting of component failure data involves the reporter's interpretation of reporting guidelines, component reportability, and available information regarding failures. This interpretation may affect the completeness and quality of NPRDS data [3.12].

Despite these drawbacks, the NPRDS is still the most comprehensive failure database available to the nuclear industry. If it is recognized that any failure rate data extracted from the NPRDS database will be a bounding value, then it can prove quite useful to determine the mean time between failures, and hence a failure rate for various system heat exchangers.

It is impractical to determine mean time between failure and failure rate data for all heat exchangers grouped into a single database. Some are located in harsh environments and are exposed to aggressive fluids while others are located in relatively benign environments and are exposed to non-aggressive fluids. Therefore, mean time between failure and failure rate data was determined for each application taking into consideration only those failures attributed to aging. The mean time between age-related failures ranged from a high of 4.4 years to a low of significantly greater than 60 years. The failure rate corresponding to the mean time between agerelated failures ranges from a high of $6.2 \times 10^{-4}$ failures per day to a low of $0.5 \times 10^{-5}$ failures per day. Because of the wide variation of failure rates, these data should be used with due caution.

In summary the NPRDS data indicates the following:

1. At least $24 \%$ of the total number of heat exchanger failures are age-related.

2. The failed components that contribute the most to age-related heat exchanger failures are tubes and coils $(68.7 \%)$, shell, internals and nozzles $(11.9 \%)$, tube sheet $(8.4 \%)$ and waterbox and divider plate $(8.3 \%)$.

3. The most significant identifiable aging mechanisms are fouling $(31.3 \%)$, corrosion $(16.8 \%)$, erosion/corrosion $(11.0 \%)$, and wear $(11.0 \%)$.

4. Increasing failure rate trends from the 1988-1989 time frame (see Figures 3-8, 3-9, and 3-10) to the present suggest that current maintenance practices should be enhanced to detect and mitigate aging of heat exchangers.

5. Heat exchangers in continuous operation with raw service water on the tube side tend to fail more frequently and, therefore, require shorter intervals between implementation of aging management activities, than do those heat exchangers with primary water, treated water, or closed cooling water on the tube side.

6. There was insufficient data available regarding failures/degradations for the following BWR plant heat exchangers.

- Spent Fuel Pool Coolers

- Reactor Water Cleanup Non-Regenerative Heat Exchanger 
- Miscellaneous Oil Coolers

- Reactor Core Isolation Cooling Lubrication Oil Cooler

- High Pressure Coolant Injection Lubrication Oil Cooler

- Emergency Diesel Generator Lubrication Oil Coolers

7. There was insufficient data available regarding failures/degradations for the following PWR plant heat exchangers:

- Spent Fuel Pool Coolers

- Miscellaneous Oil Coolers

A review of the NPRDS-reported heat exchanger aging failures versus time in service is shown in Figure 3-14. This graph indicates an increasing trend in number of failures as heat exchangers age between 1 and 17 years in service. After peaking at 17 years in service, the number of failures drops significantly. The number of heat exchanger failure events drops off significantly at year 18 because very few plants have been in commercial operation for that long. The average age of nuclear plants is 12.8 years for PWRs and 13.9 years for BWRs. The

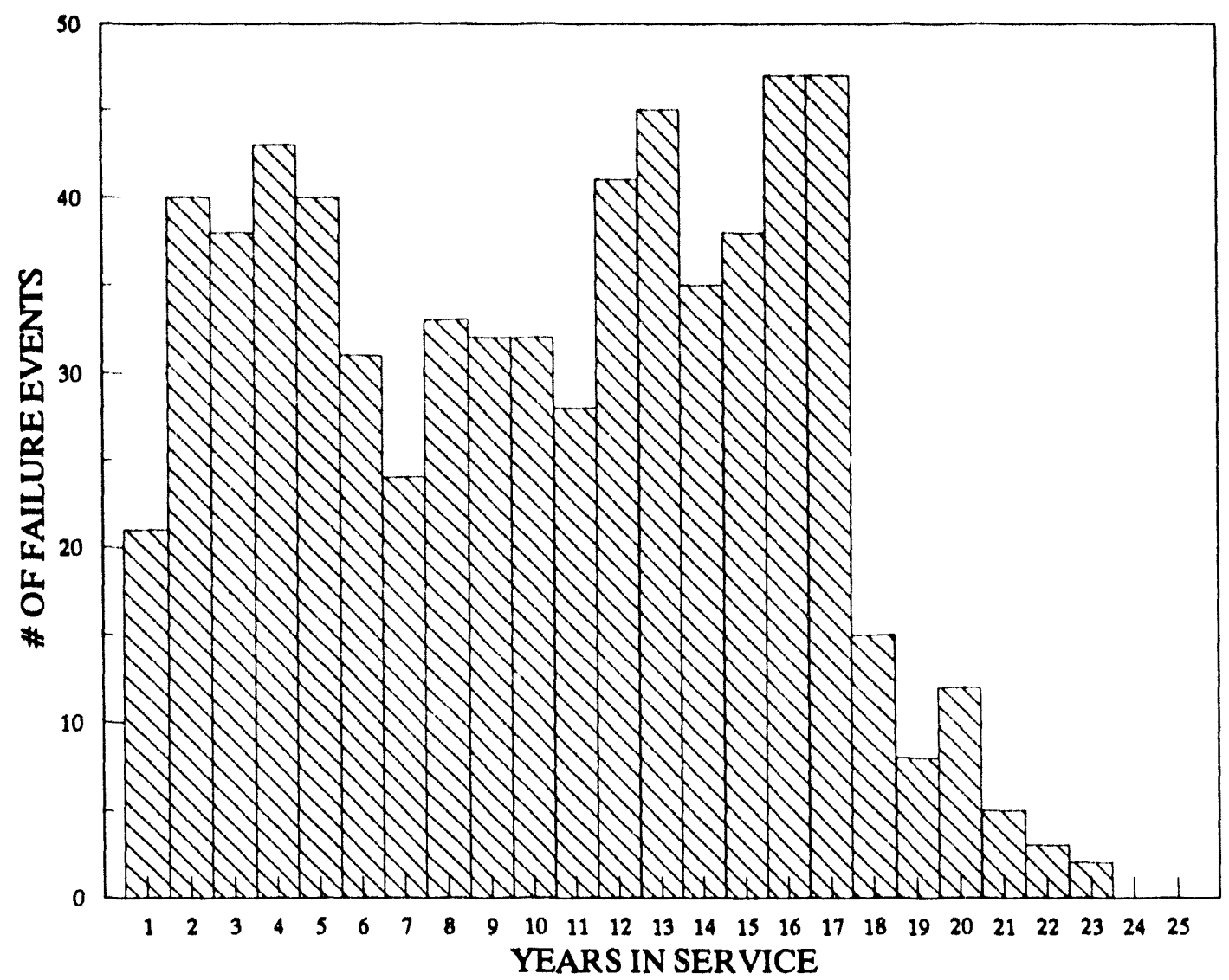

Figure 3-14. NPRDS Heat Exchanger Failures Vs. Service Time. 
average age of all plants combined is 13.2 years for the period covered by this AMG. The graph does not indicate any trend in number of failures as heat exchangers age. Seasonal trends might be expected though due to the variations in fouling.

\subsection{References}

3.1 Title 10, U.S. Code of Federal Regulations, 10 CFR Part 54, "Requirements for Renewal of Operating Licenses for Nuclear Power Plants," December 13, 1991 , pp. 64943 to 64980 .

3.2 Title 10, U.S. Code of Federal Regulations, 10 CFR Part 50.65, "Requirements for Monitoring the Effectiveness of Maintenance at Nuclear Power Plants," July 10, 1991, p. 31324.

3.3 NUMARC (Nuclear Management and Resource Council, Inc.) "Industry Guideline for Monitoring the Effectiveness of Maintenance at Nuclear Power Plants," NUMARC 93-01, Revision 2A, July 9, 1992.

3.4 Draft NUREG/CR-5779, J.C. Moyers, "Aging of Non-Power-Cycle Heat Exchangers Used in Nuclear Power Plants," April 1992.

3.5 EPRI Report NP-2331, "Steam Generator Corrosion Studies," April 1982.

3.6 EPRI Report NP-5565, "Vibration and Wear Prediction for Steam Generator Tubes," June 1988.

3.7 "Basic Heat Transfer," F. Kreith and W.Z. Black, Kreith and Black Publishers, 1980 , with permission.

3.8 EPRI NP-3877, Final Report, March 1985, "Qualification of Active Equipment for Nuclear Plants."

3.9 PNL-5722, "Operating Experience and Aging Assessment of ECCS Pump Room Coolers," D.E. Blahnik and R.L. Goodman, Pacific Northwest Laboratory, October 1986.

3.10 NUREG-0800, June 1987 Revision, "Standard Review Plan for the Review of Safety Analysis Reports for Nuclear Power Plants."

3.11 NUREG-1299, Draft, November 1990, "Standard Review Plan for the Review of License Renewal Applications for Nuclear Power Plants."

3.12 The Nuclear Plant Reliability Data System - Objectives and Uses, INPO 89-014, Revision 1, March 1991. 


\section{STRESSORS AND AGING MECHANISMS}

A stressor is a physical state or stimulus which is caused by fabrication, installation, operational conditions, and/or environmental conditions that may result in degradation of the heat exchanger. Materials used during heat exchanger manufacture, assembly, and installation are subject to some level of degradation due to residual and/or applied stressors. Also, stressors caused by normal operation and environmental conditions have a direct affect on the manifestation of aging mechanisms. It is therefore important to understand the behavior of materials, when subject to these various stressors, in order to satisfactorily operate a heat exchanger and to develop methods for detecting and mitigating heat exchanger degradation.

\subsection{Determination of Stressors Acting on Heat Exchangers}

Steady state, cyclic and peak stressors act on heat exchanger components during normal operation, transient events, and testing. These stressors can be in the form of either one or a combination of the following.
a. Mechanical
b. Hydraulic
c. Chemical
d. Electrical
e. Environmental
- Thermal
- Moisture
- Radiation

These initiators of stress are, in some applications, continuously present and active on various heat exchanger components. Stressors will cause aging mechanisms to manifest themselves over a period of time. If left undetected and/or unmitigated, these aging mechanisms result in material distortion, degradation of heat exchanger components, and unacceptable performance or failure.

For the purpose of discussion, each heat exchanger is subdivided into five major subassemblies.

- Tubes/Coils

- Tube Sheets

- Shell/Nozzles/Internals

- Waterbox/Channel Head/Divider Plate

- Pressure Boundary Fasteners/Support Assembly

The following discussion of stressors is summarized in Table 4-1. To indicate a relative measure of importance, each stressor category is quantified as either low, medium, or high. The measure of importance is subjective and is based on other aging studies, field experience, and reviews of industry data. The measures of importance shown in Table 4-1 should be applied with caution. The table does not accurately reflect all possible combinations of service and material applications for the range of heat exchangers evaluated in this AMG. This will be accomplished 
Table 4-1. Stressor Influence

\begin{tabular}{|c|c|c|c|c|c|c|c|}
\hline \multirow{2}{*}{$\begin{array}{c}\text { Heat Exchanger } \\
\text { Subassembly }\end{array}$} & \multirow[b]{2}{*}{ Mechanical } & \multirow[b]{2}{*}{ Hydraulic } & \multirow[b]{2}{*}{ Chemical } & \multirow[b]{2}{*}{ Electrical } & \multicolumn{3}{|c|}{ Environmental } \\
\hline & & & & & Thermal & Moisture & Radiation \\
\hline Tubes/Coils & High & High & Medium & Medium & Medium & Low & Low \\
\hline Tube Sheet & Medium & High & High & High & High & Low & Low \\
\hline $\begin{array}{l}\text { Partitions/ } \\
\text { Baffles }\end{array}$ & Medium & Medium & Medium & Medium & Medium & Low & Low \\
\hline $\begin{array}{l}\text { Shell/Nozzle/ } \\
\text { Internals }\end{array}$ & Medium & Medium & Medium & Low & High & Medium & Low \\
\hline $\begin{array}{l}\text { Waterbox/ } \\
\text { Channel Head/ } \\
\text { End Bell/Flange }\end{array}$ & Medium & Medium & Medium & Low & Medium & Medium & Low \\
\hline Divider Plate & Low & High & Medium & Low & Medium & Low & Low \\
\hline Floating Head & Low & Medium & Medium & Low & Low & Low & Low \\
\hline Fasteners & Medium & Low & Low & Low & Medium & Medium & Low \\
\hline $\begin{array}{l}\text { Sacrificial } \\
\text { Anodes }\end{array}$ & Low & Low & High & High & Low & Low & Low \\
\hline $\begin{array}{l}\text { Support } \\
\text { Assembly }\end{array}$ & Low & Low & Low & Low & Low & Medium & Low \\
\hline
\end{tabular}

in Sections 4.2 and 4.3. Generally, the measures of importance reflect worst case service applications. For example, the chemical stressor is rated high for service water applications, whereas, in demineralized water applications, a medium or low rating is appropriate.

\subsubsection{Mechanical Stressors}

Heat exchanger components are subject to a variety of mechanical stressors. During heat exchanger assembly, stressors are induced in the various components due to fit-up, erection tolerances, and fastener tightening. These induced stressors are classified as assembly loads and are applied to all heat exchanger components. Piping systems attached to the heat exchanger nozzles exert thrust and moments on the heat exchanger nozzles. The magnitude of stress caused by these piping loads is dependent upon the degree of pipe to nozzle misalignment during fit-up, the amount and direction of movement due to thermal expansion and contraction, and the material condition and functionality of the attached piping hanger/support network. Piping loads are applied at the inlet and outlet nozzles and distributed into the shell, waterbox, and tube sheet.

Vibration of the tubes in a heat exchanger can lead to failure due to either fatigue of the tubes or to fretting corrosion where the vibrating tubes contact baffles. Tube vibration can result from excessive shell-side flow velocities across the tubes, often in the area where shell-side flow enters the tube bundle and can be attributed to improper design or to operation at flow rates outside the design specifications. 
The tubes in a shell-and-tube heat exchanger are often fabricated from a metal having a different coefficient of thermal expansion than the shell material. In addition, the fluid temperatures in the shell and the tubes may be quite different in steady state operation or may undergo large variations in temperature, with time, during cyclic operation. As a result, in fixed tube sheet designs, tensile or compressive stresses are imposed on the shell and tubes during operation. Floating head or U-tube designs are often adopted for applications having large temperature differences to minimize differential expansion stresses. Some exchangers have a specified maximum number of lifetime thermal cycles. Cycle counting is not cnerally required because other methods can be used to detect the effects of fatigue (e.g., visual inspection).

Differential expansion stresses may lead to relaxation and leakage at rolled tube-to-tube sheet joints. In recognition of this, recommended maximum metal temperatures for various tube materials used with carbon steel tube sheets are given in the Heat Exchanger Institute's "Standard for Power Plant Heat Exchangers" [4.1].

\subsubsection{Hydraulic Stressors}

Hydraulic stressors are loads imparted on heat exchanger components as a result of the pressure and flow of fluid through the heat exchanger. The magnitude of hydraulic stress is dependent upon the characteristics of the process fluid, design parameters of the heat exchanger, and severity of operation or duty the heat exchanger is expected to encounter over its service lifetime.

Fluid pressures exert mechanical stress on the heat exchanger shell, nozzles, tubes, tube sheet, channel heads, and partitions. The exchangers are designed with sufficient strength margins to withstand those pressures expected to be encountered under both normal and accident conditions. However, exchanger damage may result from excessive pressure due to improper isolation of the exchanger from a system undergoing hydrostatic testing, from a transient pressure excursion caused by water hammer, or in the case of channel partitions, from tube flow blockage. Fluid pressures are caused by fluid weight, differential pressures, mass transfer, and cyclic operation in some applications. All of these loadings, to some degree, result in physical movement/displacement of the heat exchanger components.

Tube erosion may result from excessive tube-side velocity, excessive shell-side velocity (especially in areas near the inlet nozzles), or from suspended abrasive material in the cooling water. Recommended maximum tube-side velocities for different tube materials with clean water are included in References 4.1 and 4.2 and range from 3 to $4.6 \mathrm{~m} / \mathrm{s}$ [ 10 to $15 \mathrm{ft} / \mathrm{s}$ ] for stainless steel, nickel alloys, and titanium, to less than $1.8 \mathrm{~m} / \mathrm{s}[6 \mathrm{ft} / \mathrm{s}]$ for copper, admiralty alioy, and aluminum-brass. Lower velocities should be used with water containing erosive solids. Heat exchangers containing erosive solids in the shell side water require an impingement plate to protect the tube bundle from erosion near the shell inlet nozzle. The only heat exchanger components which would not be subject to static and dynamic hydraulic loads are the shell support assemblies. 


\subsubsection{Chemical Stressors}

Process fluids react with heat exchanger internal components, and depending on the chemical composition, can cause the heat exchanger parts to be stressed. The stress can be localized and/or uniformly distributed throughout the heat exchanger internal surfaces and involves a molecular chemical reaction between the metal and the liquid. The heat exchangers covered by this AMG handle many different types of process liquid or air and operate over a wide range of temperature and pressure. Various types of liquid are reactor water, demineralized water, well water, river water, city or fresh water, brackish water, sea water, condensate, chromated water, and lubricating oils. Some heat exchangers are exposed to the primary containment atmosphere (containment air coolers) and the reactor building atmosphere (various room coolers).

\section{Table 4-2. Galvanic Series}

Anodic End of Galvanic Series

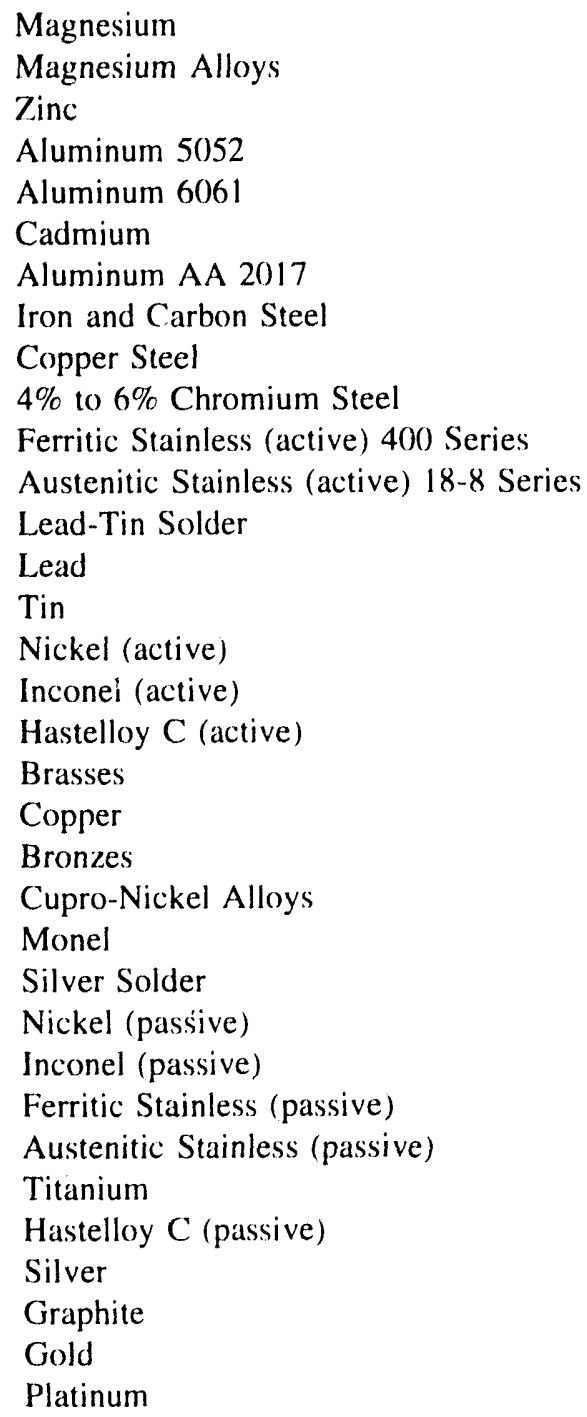


All of these liquids act as electrolytic solutions. An electrolyte is an electrical conducting medium which allows the flow of electrons between an anode and cathode. The metallic components internal to the heat exchanger act as anodes and cathodes depending on the material type. The galvanic series is shown in Table 4-2. Corrosion occurs when electrons leave an anodic material and enter the electrolytic solution. High levels of electrolyte ionization (i.e., conductivity) results in a greater rate of corrosion, because electrical current flows better in high conductivity solutions.

Another form of chemical stressor acting on the metallic surfaces of heat exchangers is the influence of living organisms on the corrosion process. In some circumstances, microbial activity does nothing more than provide a localized environment such as crevices where concentration cells are established to promote accelerated corrosion. In other cases, microbes produce metabolites such as organics or mineral acids, ammonia, or hydrogen sulfide which are corrosive to metals. Microbes can concentrate halides which result in severe, localized corrosion of ferrous materials. Microbial activity interferes with the cathodic half-reaction in oxygen free environments resulting in increased anodic dissolution. In other ways, microbes can influence (1) corrosion and oxidation of metal anions to less soluble forms, (2) destruction of protective coatings, and (3) metabolism of inhibitors [4.3].

\subsubsection{Electrical Stressors}

The only electrical stressor for heat exchangers is galvanic corrosion resulting from coupling of materials remote from one another on the galvanic series chart (Table 4-2). The potential for galvanic corrosion can be reduced by the use of sacrificial anodes, usually zinc or magnesium, inserted in the fluid path of the exchanger. See the discussion in Section 4.1.3 "Chemical Strcssors" for details regarding electrochemical corrosion.

\subsubsection{Environmental Stressors}

The following discussion includes three general parameters as environmental stressors:

- Thermal - internal process fluid temperature and external ambient temperature effects on heat exchanger components

- Moisture - external ambient humidity effects on the applicable heat exchanger components

- Radiation - cumulative internal and external radiation exposure effects on the various heat exchanger components

\subsubsection{Thermal Stressors}

Thermal stresses are active on all heat exchanger components subject to temperatures greater than $93^{\circ} \mathrm{C}\left[200^{\circ} \mathrm{F}\right]$. At high temperatures, application of a constant load to a metal component produces continuous deformation or creep, which will eventually lead to fracture if the load is maintained for a sufficient length of time. The stress-rupture strength is defined as the stress that a metal can withstand for a given time, at a given temperature, without breaking. 
With increases in temperature, stress-rupture strength decreases rapidly to values that may be considerably lower than fatigue strength. Therefore, the primary requirement of a metal that will be subjected to high temperatures is that it has adequate stress-rupture strength [4.2].

Thermal expansion or contraction of a metal, caused by a temperature change, acting against a constraint causes thermal stress. Constraints may be external (e.g., rigid mountings) or internal, in which case the constraint is set up by a temperature gradient within the part. In thick parts, temperature gradients are likely to occur both along and through the material, causing high triaxial stresses and reducing material ductility, even though the uniaxial ductility often increases with increasing temperature. Thermal fatigue is the basic failure mechanism that occurs because of numerous heating and cooling cycles. Stress rupture is an important consideration as the cycle times increase and is, therefore, a long-term rate process. Most thermal fatigue fractures are of the low-cycle, high-strain type [4.2].

Exposure of metal parts to high and low temperatures, which is often accompanied by non-uniform heating rates and sharp thermal gradients, is a source of stress during operation [4.2]. In some applications, these stressors can place the material in a state of tension. When the metal, stressed in tension, is exposed to a corrosive environment, the ensuing localized electrochemical dissolution of metal, combined with localized plastic deformation, creates a crack. With sustained tensile stress, protective films that form at the tip of the crack rupture, causing fresh anodic material to be exposed to the corrosive medium, and stress corrosion cracking is propagated [4.2]. The corrosive environment in nuclear power plants is high temperature water $>93^{\circ} \mathrm{C}\left[200^{\circ} \mathrm{F}\right]$ where the electrochemical potential of sensitized Type 304 stainless steel in the coolant is $>-230 \mathrm{mV}$ standard hydrogen electrode (SHE) [4.4, 4.5]. At reactor coolant temperatures between $54^{\circ}$ to $93^{\circ} \mathrm{C}\left[130^{\circ}\right.$ to $\left.200^{\circ} \mathrm{F}\right]$, IGSCC is not observed unless dissolved oxygen is 1 to $2 \times 10^{3} \mathrm{ppb}$. At temperatures $<54^{\circ} \mathrm{C}\left[130^{\circ} \mathrm{F}\right]$, IGSCC is not observed [4.4, 4.6, 4.7]. Figure $4-1$ is reproduced from Reference 4.4 and shows the corrosion potential vs. percent that IGSCC will occur in sensitized Type 304 stainless steel. Figure 4-2 is also reproduced from Reference 4.4 and shows an interrelation between oxygen and temperature combinations that can trigger IGSCC.

\subsubsection{Moisture Stressors}

External ambient humidity effects on the heat exchanger shell, inlet and outlet nozzles, waterbox/channel head, support assembly, and various fasteners result in general corrosion. In cases where dissimilar metals are in contact with one another, galvanic corrosion will occur in the presence of humid environments. Crevice corrosion may also manifest due to mechanical fit-up of heat exchanger components. As this type of corrosion is initiated, it proceeds in an autocatalytic manner with all the damage and metal dissolution occurring within the crevice and little or no metal loss outside. A breakdown in the passive oxide film or protective coating of a metal can provide a path for ionic migration and the development of an electrochemical cell which produces pitting. In all of these forms of corrosion, the stresses imparted on the exterior metal surfaces from moisture are electrochemical, which is described in Section 4.1.3 "Chemical Stressors." 


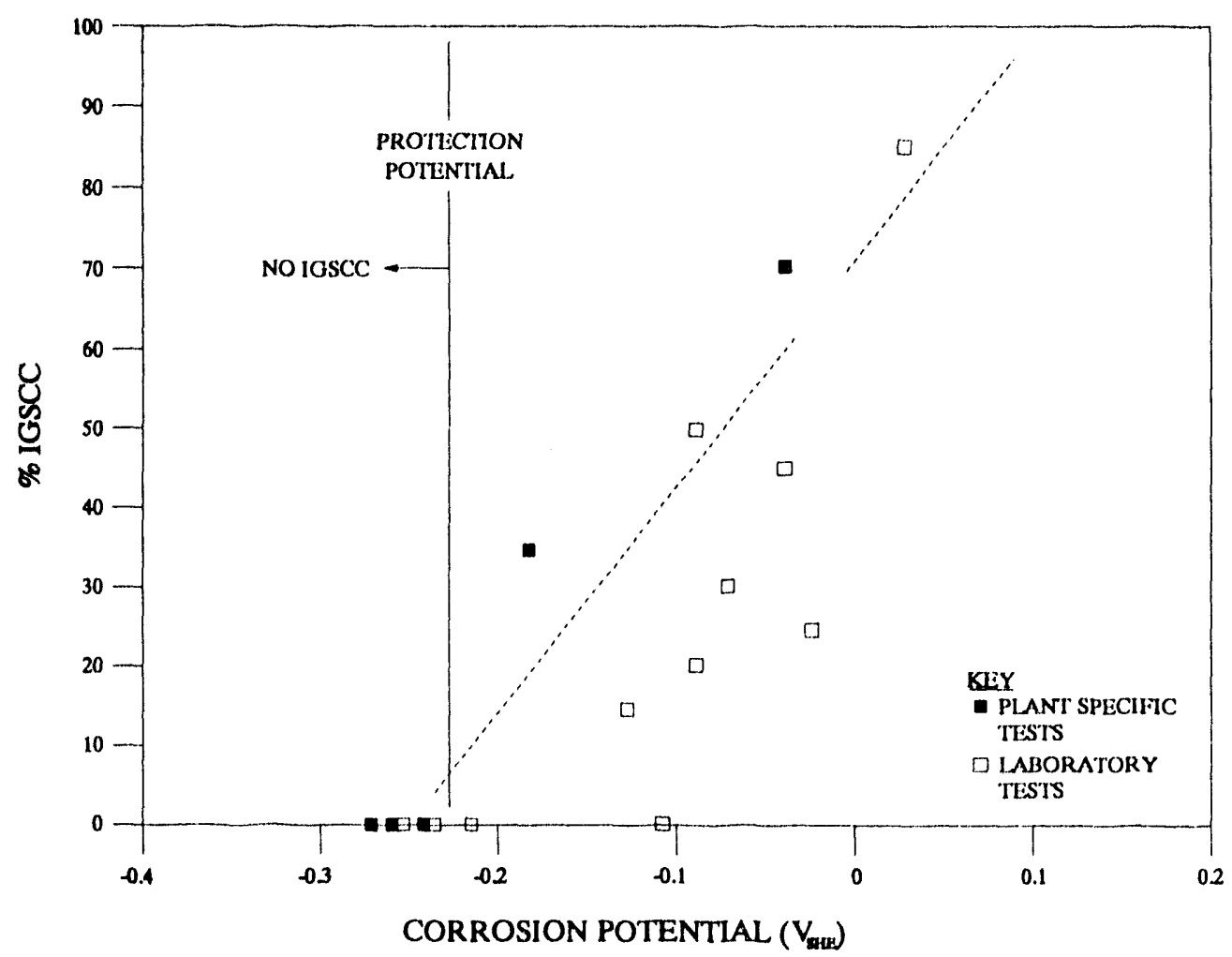

Figure 4-1. Corrosion Potential Vs. Percent IGSCC for Sensitized

Type 304 Stainless Steel [4.4].

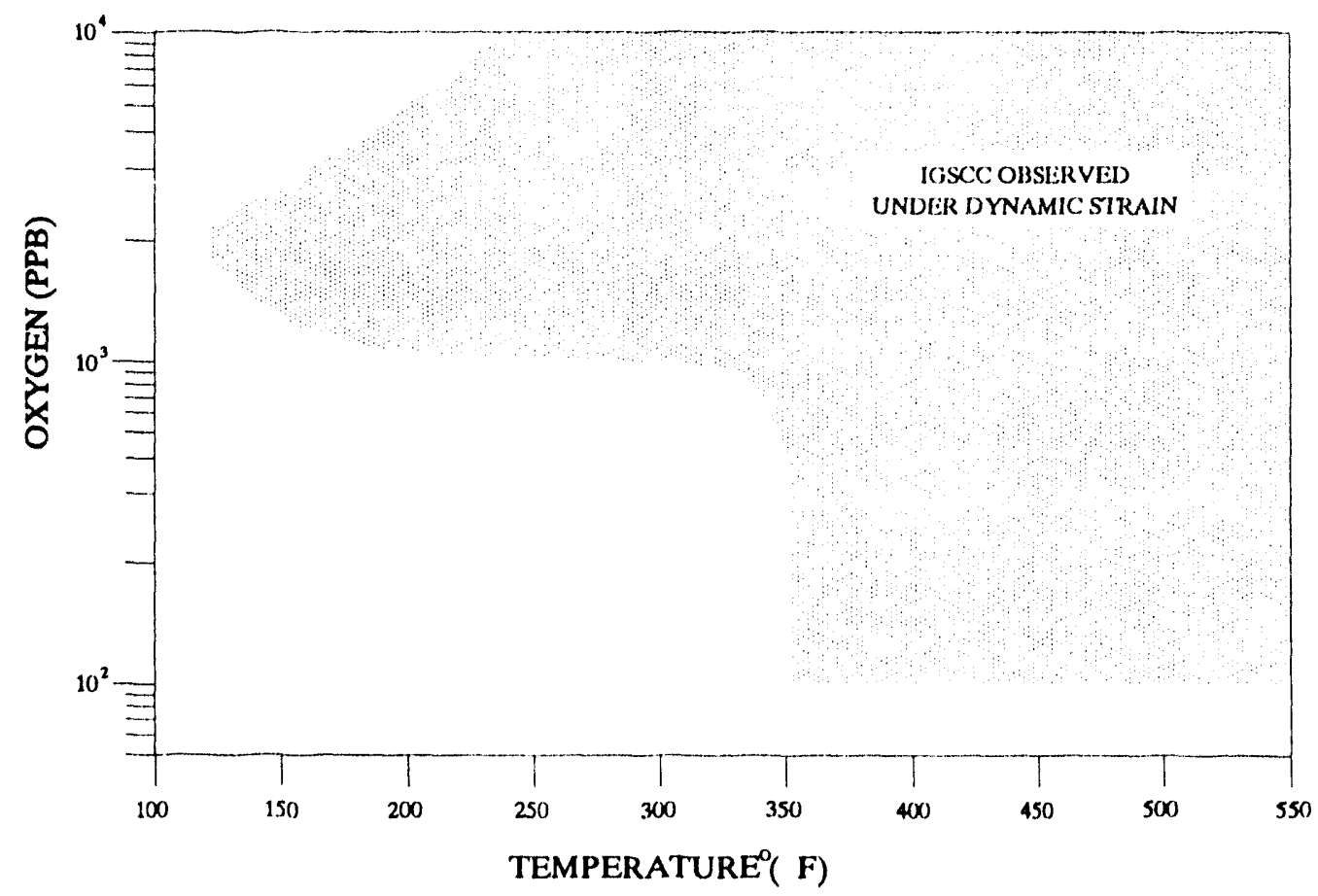

Figure 4-2. Interrelation Between Oxygen, Temperature Combinations that Can Trigger IGSCC [4.4]. 


\subsubsection{Radiation Stressors}

The following discussion of radiation stressors is applicable to all metal components of a heat exchanger and is described in generic terms. Neutrons produce energetic primary recoil atoms which displace large numbers of atoms in a metal from their crystal lattice positions by a chain of atomic collisions. This effect is characterized by exposure units such as fast fluence (> $1 \mathrm{MeV}$ ), neutrons per centimeter squared $\left(\mathrm{n} / \mathrm{cm}^{2}\right)$, or displacements per atom (dpa). Displacements per atom accounts for both the fluence and neutron energy levels. Properties of certain metals begin to change at about 0.2 dpa $\left[10^{20} \mathrm{n} / \mathrm{cm}^{2}\right]$ ). Experimental data shows that after prolonged exposure to neutrons, the yield strength increases by about a factor of three over its unirradiated value, ultimate tensile strength renains essentially unchanged, uniform and total elongation drops substantially, fracture toughness drops by about a factor of three, and the tearing modulus drops from several hundred to a range from five to ten [4.8].

The extent of embrittlement depends on neutron fluence, irradiation temperature, and trace material chemistry (i.e., particularly the presence of copper, phosphorus, and nickei) [4.9]. The degree of embrittlement is usually expressed as an upward shift of the brittle-to-ductile transition temperature and decrease in the upper shelf energy as measured in Charpy impact energy tests [4.10].

Stress corrosion cracking can occur in austenitic stainless steel components of a boiling water reactor under highly irradiated conditions. This IASCC appears to involve the simultaneous interaction of highly irradiated non-sensitized material with diffusion of metal impurities such as sulfur, silicon, and phosphorus to the grain boundaries, low stress levels, hightemperature water with short-lived oxidizing species, gamma, and neutron flux [4.11]. It is important to note that IASCC does not require the chromium depletion sensitization or high tensile stresses that are implicit in the failure of nonirradiated stainless steel components due to IGSCC discussed in Section 4.1.5.1. A threshold for IASCC exists at about $5 \times 10^{20} \mathrm{n} / \mathrm{cm}^{2}$ [>1 MeV], for austenitic stainless steel and Inconel 800 [4.12].

\subsection{Description of Aging Mechanisms Acting on Heat Exchangers}

\subsubsection{Fatigue}

Fatigue is the term that describes subcritical crack growth or structural deterioration under the influence of fluctuating or cyclic stress caused by applied loads and/or temperature. Fatigue is characterized as a macroscopically brittle mode of failure since there is no gross plastic deformation of the material before ultimate failure. When sufficient localized microstructural damage is accumulated in a defect or crack tip region (i.e., locally plastic deformation), crack initiation and growth can occur during subsequent cyclic loading and/or thermal stress.

Fatigue behavior of a component is related to a varicty of parameters, such as stress range, mean stress, frequency or cyclic wave form, environmental conditions, metallurgy of the material, and surface toughness of the material. Cracks typically initiate at local geometric stress concentration points such as notches, surface defects, and structural discontinuities. The time between localized fatigue crack initiation and eventual detection of the growing crack may represent a large portion of a component's life. Fatigue initiation curves are developed to 


\section{AGING MANAGEMENT GUIDELINE FOR HEAT EXCHANGERS}

indicate how many stress cycles it takes to initiate fatigue cracks in components. These curves are materials related and indicate the allowable number of stress cycles for applied cyclic stress amplitudes.

Environmental condition can significantly affects fatigue initiation in a material. The presence of an active environment can accelerate fatigue crack initiation and propagation. For example, oxidation can produce pits in the surface of some alloys. The pits can then act as stress concentrators and potential fatigue crack initiation sites. Environmentally assisted fatigue is commonly referred to as corrosion fatigue.

When applied or induced loads are of such magnitude that more than about 10,000 cycles are required to produce failure, the phenomenon is usually termed high-cycle fatigue. When applied or induced loads are of such magnitude that less than about 10,000 cycles are required to produce failure, the phenomenon is usually termed low-cycle fatigue. When load or strain is produced by a fluctuating temperature field, the process is termed thermal fatigue.

\subsubsection{Corrosion}

Corrosion is defined as the destruction or deterioration of a material due to electrochemical reaction with its environment. It is characterized by material loss or deterioration of its properties. Corrosion reduces the component wall thickness, either locally (e.g., crevice corrosion, pitting, galvanic corrosion, microbiologically influenced corrosion, etc.) or more uniformly (e.g., rusting, oxide layering, etc.). The resultant decrease in the volume of sound material causes a decrease in the strength of the corroded material. Furthermore, the associated surface roughening causes additional weakening of the material when placed under load.

\subsubsection{General/Uniform Corrosion}

General/uniform corrosion results in the formation of solid corrosion products (oxides) that protect the underlying metal surface. Localized disruptions in the oxide will re-oxidize, rendering the metal protected from further corrosion. Changes in environmental conditions, however, can have an adverse affect on the stability of the protective oxide layer rendering the material susceptible to increased general/uniform corrosion.

General/uniform corrosion of metal surfaces exposed to the atmosphere is caused by the combined effects of film formation and film breakdown. Film formation is the iron oxide layering of a metal surface that develops from exposure to oxygen in the surrounding environment. This film develops cracks, disruptions, and discontinuities which are caused by (1) external forces and/or (2) stresses internal to the oxide layer (i.e., caused by different types and volumes of metal and iron oxide located throughout the layer). Moisture in the surrounding atmosphere, from water leakage or humidity, is an electrolyte and provides a path for electrochemical reactions to occur. The most damaging reaction (i.e., film breakdown) is caused by electrical current continuously flowing between the small anodic areas of freshly exposed metal and the much larger cathodic areas of the oxide layer. The anodic areas corrode further and the process of film breakdown continues. The general/uniform corrosion rate is highly dependent upon the availability and purity of the electrolyte. 
General/uniform corrosion rates of heat exchanger internal surfaces are dependent upon process fluid oxygen content, operating temperature, and flow rate. Heat exchanger internals are exposed to a variety of fluids, consisting of reactor water, low temperature deionized water, high temperature deionized water, city or fresh water, salt or brackish water, chromated water, and various types of lubricating oils. Some system heat exchangers are maintained stagnant for long periods of time while others are maintained in a condition of continuous flow. The highest general/uniform corrosion rates for metal occurs in system applications where the fluid is low temperature air saturated stagnant water [4.11]. Very little general/uniform corrosion occurs in (1) high temperature water systems because a thin black oxide film (i.e., magnetite) forms rapidly, protecting the internal surfaces from further general/uniform corrosion, and (2) systems containing lubricating oil because oxygen content is very low, oils are not good electrolytes, and purification systems are generally installed and/or corrosion inhibitors are added to maintain the oil free of corrosion products.

Copper-zinc alloys containing more than $15 \%$ zinc are susceptible to a dealloying process called dezincification. Dezincification of copper-zinc alloys is most prevalent in waters containing a high content of oxygen, carbon dioxide, or chloride and is accelerated by elevated temperatures and low water velocity. Excessive chlorination of cooling water may promote dezincification of copper-zinc alloys. Dealloying is a general/uniform corrosion process in which the more active metal is selectively removed from an alloy (i.e., zinc), leaving behind a weak, porous layer of the more noble metal (i.e., copper and copper oxide). Tin tends to inhibit dealloying and where dezincification is a problem, red brass, commercial bronze, inhibited admiralty metal, and inhibited aluminum brass can be successfully used.

In systems containing slightly acidic water, low in salt content and at room temperature, the dezincification is likely to be uniformly distributed throughout the material. In systems containing neutral or alkaline water, high in salt content and above room temperature, the dezincification is likely to be localized with the surrounding material unaffected or slightly corroded [4.13].

\subsubsection{Pitting}

Localized pitting produces small craters or holes in the metal which reduces load-bearing capacity and creates stress risers. Pitting occurs when one area of a metal surface becomes anodic with respect to the rest of the surface, or when highly localized changes in the environment in contact with the surface cause accelerated corrosion. Most pits develop and grow downward from the metal surface in the direction of gravity; rarely do they grow upward opposite gravity.

Causes of pitting include local inhomogeneities on or beneath the metal surface, local loss of passivity, mechanical or chemical rupture of the protective oxide surface film, galvanic corrosion from a relatively distant cathode, and the formation of a metal ion or oxygen concentration cell under a solid deposit (crevice corrosion). The rate of penetration into the metal by pitting may be 10 to 100 times greater than for general corrosion. Low fluid velocity and/or stagnation is usually associated with the development of pitting. 
Cavitation and erosion pitting can be found in high velocity turbulent flow areas of a heat exchanger which is predominantly in the tube bundles. This type of pitting is caused by the mechanical action of cavitation vapor bubbles or entrained gas bubbles.

\subsubsection{Galvanic Corrosion}

Galvanic corrosion is an accelerated electrochemical corrosion that occurs when two dissimilar metals in contact are made part of an electrical circuit which is completed by a connecting pool or film of electrolyte or corrosive medium. Under these circumstances, the potential difference between the dissimilar metals produces a current flow through the conducting electrolyte. In this case, the less noble of the two metals will become the anode and will corrode. Galvanic corrosion does not require oxygen but does require water or some other conductive medium. Galvanic corrosion will exist at dissimilar metal contact points where (1) surfaces are not adequately protected and (2) surfaces are exposed to moisture for prolonged periods of time. Galvanic corrosion will be localized in its attack and the resultant corrosion products may cause stress to an adjacent component due to oxide wedging or formation of crevices. Stress induced on an adjacent component, caused by the volume increase in corrosion products, could cause other degradation mechanisms to occur.

All metals or alloys will react as either an anode or a cathode when in contact with dissimilar metals or alloys. Whether a particular material will react as a cathode or an anode is determined from the relative positions of the materials with respect to one another as shown on Table 4-2, the galvanic series chart. The further apart two materials are from each other (on the chart), the greater the rate of corrosion. The material closest to the anodic end of the chart will be the one to corrode.

The rate of galvanic corrosion is also affected by the relative size of the materials and composition of the electrolyte. A small anode area in contact with a large cathode area will result in a rapid severe corrosion. Conversely, a large anode area in contact with a small cathode area will lessen the rate of galvanic corrosion since the same total current flow will be spread out over a large area. Higher levels of electrolyte ionization (i.e., conductivity) result in a greater rate of galvanic corrosion because electrical current flows better in high conductivity electrolytes.

The effects of galvanic corrosion are minimized by:

1. Insulating the dissimilar metals from each other using nonconductive coatings, such as paint.

2. Eliminate the electrolyte.

3. Where different metals are used, choose those that are close together in the galvanic series.

4. Use the anode metal for large surface area components and the cathode metal for small surface area components.

5. Protect the metals with a sacrificial anodic metal. 


\subsubsection{Microblologically Influenced Corrosion (MIC) and Tuberculation}

MIC is characterized by the formation of discrete deposits (e.g., microbial colonies and associated scale and debris) on the surface of the metal or alloy, such as carbon steels, stainless steels, copper, and nickel alloys. Pitted surfaces are usually covered by the micro-organism deposits with the pit entrance being smaller than the overlaying deposit. In stainless steels, the deposits and pitting are usually found in the associated weld and heat-affected zones. The deposits usually contain:

1. Large amounts of iron and manganese regardless of the type of alloy.

2. Silicon, sulfur, and chloride are often found.

3. Phosphorus is occasionally found.

4. Copper is usually found in high amounts if a copper alloy is involved.

A large number of different organisms are involved in MIC, depending on the alloy and the environmental conditions. However, there is considerable evidence that the deposit forming iron and manganese bacteria, the slime-forming Pseudomonas type of bacteria, the deposit forming and iron reducing bacillus type organisms, and the sulfate reducing bacteria are of principal importance.

Temperature, pressure, $\mathrm{pH}$, water content, salinity, redox potential (i.e., oxygen), and types and quantities of nutrients available are among the important factors influencing the microbes in their attempts to live in a given location. The following discussion is a generally accepted range over which organisms as a group are known to exist.

Temperature. Microbes can survive over at least the range $-20^{\circ}$ to $99^{\circ} \mathrm{C}\left[-4^{\circ}\right.$ to $\left.210^{\circ} \mathrm{F}\right]$. The range of temperatures over which microbes are most often found growing are from about $0^{\circ}$ to $80^{\circ} \mathrm{C}\left[32^{\circ}\right.$ to $\left.176^{\circ} \mathrm{F}\right]$.

Pressure. Most organisms tolerate pressures up to $31 \mathrm{MPa}[4,500 \mathrm{psi}]$.

$\mathrm{pH}$. Microbes as a group can thrive in environments with $\mathrm{pH}$ levels ranging from 1 to at least 10.0. Also, bulk water values for $\mathrm{pH}$ can be misleading. The $\mathrm{pH}$ in bulk water may be 8.0 while at the surface of the metal under the microbial deposit (i.e., where fermentation is producing organic acids), the pH level can be much lower (i.e., 4.0 or less).

Water Content. All microorganisms require metabolically available water for survival. That is, it must not be in the form of ice or chemically complexed in such a way as to be inaccessible to the microbes.

Salinity. Many fresh water or terrestrial microbes thrive in deionized or demineralized water. These microbes can survive in very low levels of salts, or they can find elevated salt concentrations at surfaces of the metal. 
Redox Potential. Microbes may (1) require oxygen at levels of about 0.01 atm or greater for growth, (2) require minute levels of oxygen for growth, (3) require no oxygen for growth, or (4) grow under any of these conditions.

Nutrients. Microbes require inorganic molecules (e.g., ammonia, nitrate, methane, etc.) as a source of energy and organic molecules and/or carbon dioxide as a source of carbon for growth. Most nuclear facilities use demineralized water because the deionization removes many of the nutrients from the water. However, the remaining nutrients do accumulate and concentrate at the surfaces of pipes, tanks and heat exchangers, and the microbes follow the nutrients to these locations.

Tuberculation is the formation of tubercules by biological organisms acting in conjunction with electrochemical corrosion and occurs in many environments and on many alloys. Tubercules can form without the presence of any microorganisms; however, tuberculation usually takes place in biologically active aqueous systems.

The process of tubercule formation is complex. Any biofilm that does not provide for complete uniform coverage of the entire immersed surface of a metal or alloy has the potential to form concentration cells. Corrosion products are formed at these concentration cells. The corrosion products generally result in formation of pits at anodic areas under the bicfilm. The corrosion products also join with the biofilm to form a corrosion tubercule. A gradual buildup of these corrosion tubercules can ultimately result in macrofouling.

\subsubsection{Stress Corrosion Cracking}

SCC is the term given to subcritical crack growth in certain alloys when subjected to stress and a corrosive environment. Many alloys are susceptible to SCC in at least one environment; however, SCC does not occur in all environments, nor does an environment that induces SCC in one alloy necessarily induce SCC in another alloy [4.14].

Three factors or conditions must be present simultaneously for the possibility of SCC to occur. Elimination or a reduction in any one or a combination of these three factors will significantly reduce the likelihood or eliminate the possibility for SCC to occur. The three factors are:

- Susceptible Material (Metal Alloy)

- Tensile Stress (Applied and/or Residual)

- Corrosive Environment (an environment that can provide the chemical driving force for corrosion reaction)

Tensile stresses causing stress corrosion cracking are typically at material yield strength levels. However, stress levels causing stress corrosion cracking may sometimes be below the yield strength. Material susceptibility is related to the environment and may be influenced by the metallurgical condition of the material. 


\subsubsection{Intergranular Stress Corrosion Cracking (IGSCC)}

IGSCC can be divided into two basic categories: (1) grain boundary precipitation and (2) grain boundary segregation. The effect of grain boundary precipitation in austenitic stainless steel is carbide precipitation which causes depletion of chromium adjacent to the grain boundary. The grain boundary then becomes anodically active and susceptible to corrosion. Impurities in a metal can segregate and produce a grain boundary that approaches $50 \%$ impure. The effect of these impurities alters the corrosion and mechanical properties of the grain boundary and causes cracking by anode dissolution.

The heat exchanger tubing alloys most commonly affected by this cracking are brass and Type 304 stainless steel. The common corrodant for brass is ammonia, while chloride is the primary contributor for 304 stainless steel. Section 4.2.3.3 below provides further information about the parameters and characteristics that must be present for chloride SCC to occur. The stress corrosion cracks originating either on the ID or OD side follow in the direction perpendicular to the existing tensile stress.

Without the presence of tensile stress, it is possible to have just the intergranular corrosion without cracking. This is an infrequently encountered form of attack observed in applications involving mainly high-pressure steam. The intergranular corrosion penetrates the tube wall along grain boundaries without the apparent loss of tube wall thickness. The remaining wall, however, is brittle and provides no load-bearing strength. The susceptible alloys for this form of attack are Muntz metal, admiralty brass, aluminum brasses, and silicon bronzes.

\subsubsection{Irradiation Assisted Stress Corrosion Cracking (IASCC)}

Manifestation of IASCC involves simultaneous interaction of highly irradiated nonsensitized material with diffusion of impurities to the grain boundary, low stress, and high temperature water containing short-lived oxidizing species associated with gamma and neutron flux. Based on available field and laboratory data, a threshold fast neutron fluence (energy $>1 \mathrm{MeV}$ ) of approximately $5 \times 10^{20} \mathrm{n} / \mathrm{cm}^{2}$ appears to exist for IASCC to occur in stainless steel or Alloy 600. Formation of IASCC does not require chromium depletion sensitization at the grain boundary or presence of high tensile stress.

\subsubsection{Transgranular Stress Corrosion Cracking (TGSCC)}

TGSCC differs from IGSCC in that the cracking (i.e., failure mode) occurs through or across the grain boundary as opposed to along the grain boundary. Sometimes the failure mode of an alloy can be a combination of TGSCC and IGSCC and at other times the failure mode can switch either from IGSCC to TGSCC or from TGSCC to IGSCC. IGSCC and TGSCC often occur in the same alloy depending on the service environment, microstructure of the metal, or the applied or residual stress/strain state.

The combination of aqueous chlorides and austenitic stainless steel may cause chloride stress corrosion cracking to occur. Chloride SCC of austenitic stainless steel:

- Seldom occurs at metal temperatures below $60^{\circ} \mathrm{C}\left[140^{\circ} \mathrm{F}\right]$ and above $199^{\circ} \mathrm{C}\left[390^{\circ} \mathrm{F}\right]$. 
- Requires an aqueous environment containing dissolved air or oxygen or other oxidizing agents.

- Occurs at very low tensile stress levels such that stress relieving heat treatments are seldom effective as a preventive measure.

- Affects all the austenitic stainless steels about equally with regard to susceptibility, time-to-failure, etc.

- Is characterized by transgranular branchlike cracking.

Chloride SCC is a concern for austenitic stainless steel heat exchanger components exposed to a chlorinated reservoir or pond where chlorides tend to concentrate.

\subsubsection{Erosion and Erosion/Corrosion}

Erosion is attributed to the removal of protective oxide films on a metal and/or the base metal by mechanical action of a flowing fluid or particulate. Solid particles, present in a flowing fluid, impinge on internal surfaces particularly at flow discontinuities and cause low stress scratching (i.e., abrasive wear) of the surface. Due to the principles of momentum and mass iransfer, the magnitude of stress and therefore severity of abrasive wear is directly related to the fluid velocity.

When the local pressure in a flowing liquid is reduced without a change in temperature, vapor-filled bubbles can form and expand within the flowing liquid. When these bubbles, which are formed in the low pressure region, pass into a region of higher pressure, expansion is reversed and the bubbles implode/collapse very rapidly. This process is called cavitation. Cavitation causes localized force/stress to be imparted on the oxide layer and underlying base metal surface which results in damage to the material in the form of erosion.

Erosion/corrosion occurs when the fluid or particulate matter is also corrosive to the metal. The mechanism of erosion and erosion/corrosion involves electrochemical aspects of general corrosion, mass transfer, and momentum transfer. In an erosion/corrosion process: (1) a corrosive fluid forms an oxide layer on the surface of the metal, (2) erosive action removes this oxide layer, and (3) the newly exposed bare metal surface continues the corrosion process. This action of simultaneous oxide formation and removal leads to a reduction of metal thickness and is usually characterized by a pattern of grooves or peaks and valleys generated by the flow pattern of the corrosive fluids.

The principal factors affecting erosion and erosion/corrosion are:

Temperature. Maximum erosion/corrosion rates in single-phase flow occurs between $130^{\circ}$ to $140^{\circ} \mathrm{C}\left[265^{\circ}\right.$ to $285^{\circ} \mathrm{F}$ ].

Materials. Low alloy and plain carbon steel and copper or a copper alloy such as brass are most susceptible to erosion and erosion/corrosion. Alloying elements, such as chromium and molybdenum (for carbon steels) and nickel or bronze (for copper based materials), improve 
resistance to erosion and erosion/corrosion. Austenitic stainless steels are highly resistant to erosion and erosion/corrosion.

Water Chemistry. The rate of erosion/corrosion in single phase fluid flow applications varies depending on the dissolved oxygen content and $\mathrm{pH}$ level. When the $\mathrm{pH}$ value is maintained neutral, the rate of erosion/corrosion decreases as dissolved oxygen content increases. Operation near $50 \mathrm{ppb}$ dissolved oxygen in a neutral pH fluid (e.g., 7) reduces the rate of erosion/corrosion in carbon steel materials to negligible levels.

Flow Velocity/Configuration. Erosion and erosion/corrosion is most prevalent in regions where (1) high flow velocity exists, (2) turbulent flow is present, and (3) where the geometry causes flow directional changes.

Neither material hardness characteristics nor corrosion resistance properties, when existing alone, are sufficient for a particular metal to resist the effects of erosion and erosion/corrosion. Therefore, metals, such as stainless steel and high alloy steels, which possess both high corrosion resistance and high hardness properties are less susceptible to the effects from erosion and erosion/corrosion than metals, such as plain carbon steel and copper alloys, which possess lower corrosion resistance and hardness properties.

\subsubsection{Embrittlement}

Structural or chemical changes induced by elevated temperatures, contaminants, or radiation causes embrittlement of metals which can lead to fragility and failures under dynamic loading. There are two predominant initiators of embrittlement that could possibly affect nuclear plant components: (1) thermal embrittlement and (2) neutron embrittlement.

\subsubsection{Thermal Embrittlement}

The mechanism of thermal embrittlement is complex and varies with material composition and service conditions. Fine grained, high chromium stainless steels normally possess good ductility. However, exposure to high temperature increases strength while at the same time reduces ductility and fracture toughness properties of the material. Susceptibility to embrittlement increases with increasing chromium content, with the highest degree of embrittlement occurring when chromium content is greater than $19 \%$. At least $15 \%$ chromium is necessary for embrittlement to occur [4.15]. The effect of carbon content on embrittlement is minimal [4.15]. The effects of thermal embrittlement on cast austenitic stainless steel are most prevalent at temperatures between $400^{\circ}$ to $500^{\circ} \mathrm{C}\left[750^{\circ}\right.$ to $\left.930^{\circ} \mathrm{F}\right]$ when maintained for long periods of time (e.g., greater than 100,000 hours).

\subsubsection{Neutron Embrittlement}

Neutrons produce energetic primary recoil atoms which displace large numbers of atoms from their crystal lattice positions by a chain of atomic collisions. The neutron damage exposure can be characterized by displacements per atom (dpa), which accounts for the neutron energy spectrum as well as the fluence. However, the dpa exposure parameter is not a direct measure of the number of residual defects; the primary defects undergo temperature dependent 
rearrangements both within the chain and as a consequence of long range migration. Only a fraction of the primary defects survive in the form of small clusters or cluster solute complexes. Excess point defects created by radiation also accelerate diffusion, including the formation of small copper rich phases.

Embrittlement is a function of radiation exposure and environmental and metallurgical variables. Fluence or dpa, and copper and nickel content have been identified as the primary contributors. Important second order variables include flux, temperature, and phosphorous content. There is evidence that a number of other variables such as heat treatment may also influence embrittlement. Available experimental data suggest that the following metallurgical properties result after prolonged exposure to neutrons:

- The yield strength increases by about a factor of 3 over its unirradiated value while the ultimate tensile strength remains essentially unchanged.

- The uniform elongation and the total elongation drop substantially from their unirradiated values.

- Fracture toughness drops by about a factor of 3 to 4 , tearing modulus drops from several hundred to a range from 5 to 10 .

Experimental data also suggests that an accumulated fast ( $>1 \mathrm{Mev}$ ) neutron fluence of approximately $1 \times 10^{20} \mathrm{n} / \mathrm{cm}^{2}$ is the threshold value where these metallurgical properties begin to change $[4.8,4.9,4.12]$.

\subsubsection{Wear}

Wear is defined as damage to a solid surface by the removal or plastic displacement of material by the mechanical action of a contacting solid, liquid, or gas. There are three primary types of wear: adhesive wear, abrasive wear, and erosive wear.

\subsubsection{Adhesive Wear}

Adhesive wear is identified by commonly known terms such as scoring, galling, seizing, and scuffing and is further characterized as transference of material from one surface to another during relative motion or sliding due to a process called solid phase welding (i.e., particles from one surface are removed and either permanently or temporarily attached to the other surface).

\subsubsection{Abrasive Wear}

Abrasive wear or abrasion is identified by commonly known terms such as scouring and gouging and is characterized as displacement of material from a solid surface due to hard particles sliding along the surface. Scouring and gouging may be due to loose particles entrapped between surfaces that are in relative motion or from hard particle impingement that fractures the surface of the material such as in grinding applications. 


\section{AGING MANAGEMENT GUIDELINE FOR HEAT EXCHANGERS}

\subsubsection{Erosive Wear}

Erosive wear is identified by commonly known terms such as erosion, cavitation, and droplet impingement and has been fully discussed in Section 4.2.4.

\subsubsection{Stress Relaxation}

Stress relaxation is an elevated temperature age-related degradation mechanism important in the design of devices intended to hold components in contact under pressure. Stress relaxation occurs under high temperature conditions of constant strain where elastic deformation is replaced by plastic deformation. Materials loaded to some initial stress may experience a reduction in stress over time at high temperatures. The reduction in prestress generally occurs at a decreasing rate with the majority of loss occurring early in life of the prestressed part.

Factors affecting stress relaxation are (1) material type, (2) neutron fluence, (3) time, (4) temperature, and (5) amount of initial prestress. A significant magnitude of fast neutron fluence will not accumulate due to location of these components relative to the reactor core, therefore, the contribution of neutron fluence is negligible. Stress relaxation is a concern only for materials that are subject to high initial prestress conditions and exposed to high temperatures for prolonged periods of time.

\subsubsection{Creep}

Creep is defined as time-dependent strain, or gradual elastic and plastic deformation of metal that is under a constant stress at a value lower than its normal yicld strength. The type of fracture (ductile or brittle) caused by creep depends on temperature and strain rate. The effect is particularly important if the temperature under which the component is stressed is near the recrystallization temperature of the metal.

When tensile stress is applied to a metal, the metal undergoes initial elastic strain. Following this initial elastic strain with the tensile stress continually applied, the metal will undergo increasing plastic strain at a decreasing strain rate. This is called first stage or primary creep. Following first stage creep, there is an equilibrium condition consisting of a nominally constant rate of plastic strain. This is called second stage or secondary creep. The duration of secondary creep depends upon the temperature and applied tensile stress on the metal. Following second stage creep is a condition of drastically increased strain rate with rapid extension to fracture. This is called third stage or tertiary creep.

\subsubsection{Fouling}

Fouling interferes with normal flow characteristics and will reduce heat exchanger efficiency. There are three general types of fouling found in heat exchangers [4.16, 4.17]:

- Particulate Fouling

- Biological Fouling

- Precipitation Fouling 


\subsubsection{Particulate Fouling}

Water-borne deposits, commonly known as foulants, are loose, insoluble materials suspended in the fluid. Particulate fouling is the accumulation of foulants (e.g., silt, sediment, clay, sand, and/or corrosion products) onto the heat transfer surfaces of the heat exchanger. There are three primary factors that contribute to the severity of particulate fouling: (1) suspended solids concentration, (2) heat exchanger tube velocities, and (3) system operating practices.

\subsubsection{Biological Fouling}

Biological fouling, commonly referred to as biofouling, occurs by attachment of large or small crganisms to heat exchanger surfaces. This macrofouling is responsible for degraded heat exchanger performance characterized as flow retardation, accumulation of concentration cells and microbiologically influenced corrosion, and/or inhibited heat transfer capability.

When the attached biological material layer becomes thick, water flow and heat transfer capability is impeded. During high flow conditions, dislodgement of shells and other debris may occur resulting in further pluggage and flow retardation. Presence of concentration cells beneath biological masses is common especially if the water is stagnant. Stagnant water systems are ideal incubators for promoting the growth and proliferation of microorganisms. If large organisms are actively growing, microbes will more than likely be present, and their activity will result in direct corrosion of heat exchanger surfaces.

The Asiatic clam and zebra mussel are the principal organisms causing macrofouling in fresh water systems. In brackish water and seawater, macrofouling is caused by the blue mussel and the American oyster.

\subsubsection{Precipitation Fouling}

Precipitation fouling occurs by the crystallization of dissolved ions from solution onto the heat-transfer surface. Calcium carbonate, calcium sulfate, calcium phosphate, magnesium silicate, iron, manganese, and silica are the precipitants most commonly found in cooling waters. Calcium carbonate is the most prevalent precipitant found in nuclear plant cooling water systems [4.13]. Primary water applications in PWR plants contain boron to control reactivity. Cases have been identified in industry data that show precipitate fouling from borated compounds. Precipitation fouling is commonly known a.s scaling because of its appearance. Precipitation fouling depends mainly upon fluid temperature, alkalinity or acidity, and concentration of scaleforming ions.

\section{Calcium Carbonate}

The amount of calcium carbonate scaling within a cooling water system directly depends on the concentrations of calcium hardness and bicarbonate alkalinity. The formation of this scale increases with $\mathrm{pH}$ and temperature. 


\section{Calcium Phosphate}

Calcium phosphate scaling is generally found in two types of waters: (1) cooling waters treated with phosphate-based corrosion inhibitors and (2) cooling water supplied by partially treated sewage waters or rivers/lakes surrounded by farm runoff. Calcium phosphate precipitates out at higher $\mathrm{pH}$ and temperature.

\section{Calcium Sulfate}

Calcium sulfate scaling is caused by high concentrations of calcium and sulfate. It becomes less soluble at low $\mathrm{pHs}$ and higher temperatures. Calcium sulfate precipitation is an indication of severe fouling, because it does not occur until after all of the carbonate has precipitated out of the water.

\section{Magnesium Silicate}

Magnesium silicate scaling forms first as magnesium hydroxide as a result of precipitation of magnesium carbonate. The magnesium hydroxide then reacts with silica to form magnesium silicate. This scale is the hardest to remove from heat transfer surfaces and is common to cold water applications, because the solubility of silica increases with temperature.

\section{Silica}

Silica precipitate scaling occurs predominantly in cold water applications, because the solubility increases with temperature. Maintaining the silica concentration less than $150 \mathrm{ppm}$ as $\mathrm{SiO}_{2}$ in cooling water applications should minimize its deposition on heat transfer surfaces regardless of temperature.

\section{Iron and Manganese}

Iron fouling is common in cooling water applications that are supplied by iron-laden well water or rivers high in iron concentration. Manganese deposits are usually found in the form of manganese dioxide. Relatively low concentrations of manganese will cause scaling/deposition of heat transfer surfaces. Manganese concentrations of concern are usually found in cooling water applications where the source is from (1) bodies of water where acid mine drainage exists and (2) bodies of water covering areas that once were pine forests. Manganese dioxide scaling/deposits will precipitate as a result of oxidation of manganese by over-chlorination or by microorganism growth on heat-transfer surfaces.

\section{Boron Solutions}

Borated compounds will precipitate under certain concentration and temperature conditions. Boron precipitate fouling occurs predominantly in cold water applications because the solubility increases with temperature. In a typical PWR plant, the solubility limit is 20,000 ppm boron at $54^{\circ} \mathrm{C}\left[130^{\circ} \mathrm{F}\right]$. 


\subsection{Evaluation of the Aging Mechanisms}

This section addresses the significance of each aging mechanism described in Section 4.2. An aging mechanism is significant when, if allowed to continue without detection or mitigation measures, it will cause the heat exchanger to lose its ability to perform its required function. The aging mechanisms are evaluated for each of the major heat exchanger subassemblies. The results of the evaluations are summarized in Tables 4-3 through 4-8.

Many of the relationships between the aging mechanisms described in Section 4.2 and the heat exchanger applications listed in Tables 3-7 and 3-8 apply to all the heat exchangers evaluated in this AMG. These relationships are described and evaluated in Section 4.3.1. The significance of some of the aging mechanisms is determined by this evaluation. In Section 4.3.2, the mechanisms are further examined, as necessary, by considering the affected heat exchanger subassemblies, service application, fluid characteristics, and construction materials. Figure 4-3 depicts common heat exchanger tube degradation which is typically caused by any one or a combination of the aging mechanisms evaluated in Sections 4.3.1 and 4.3.2.

Where aging mechanisms are classified as significant or non-significant, qualification tatements are included as necessary. Since many different plant-specific situations exist, aging mechanism significance may only apply to certain environments, heat exchanger materials, and services, etc. The aging mechanism significance evaluations carefully consider whether or not the operational and environmental stressors may cause significant degradation for a specifi: component over long periods (40 years or more), even if industry history has not documented such degradation.

Finally, two special issues are addressed; aging mechanism synergies and dependencies in Section 4.3.3 and a comparison with Nuclear Plant Aging Research (NPAR) results in Section 4.3.4.

\subsubsection{Aging Mechanism Considerations that Apply to all Heat Exchangers}

The relationships between the aging mechanisms described in Section 4.2 and the applications described in Section 3 are evaluated in this subsection. The intent of this subsection is to consolidate the determinations of significance or non-significance, wherever possible, or to present the considerations that need to be examined in Sections 4.3.2; evaluations of the subassemblies and heat exchanger service applications.

\subsubsection{Thermal Embrittlement, Stress Relaxation, and Creep}

Normal fluid operating temperatures for several heat exchanger applications are below the $93^{\circ} \mathrm{C}\left[200^{\circ} \mathrm{F}\right]$ threshold levels established for thermal embrittlement, stress relaxation, and creep $[4.5,4.15,4.18]$ in Sections 4.2.5, 4.2.7, and 4.2.8. The RHR heat exchangers, associated with both BWR and PWR plants, and the RWCU non-regenerative heat exchangers for BWR plants operate at fluid temperatures above $93^{\circ} \mathrm{C}\left[200^{\circ} \mathrm{F}\right]$ during other (than normal) modes of plant operation. The RHR heat exchangers operate at fluid temperatures above $93^{\circ} \mathrm{C}\left[200^{\circ} \mathrm{F}\right]$ for short periods immediately following reactor shutdown to remove decay heat. Fluid temperatures may initially be in the $177^{\circ} \mathrm{C}\left[350^{\circ} \mathrm{F}\right]$ range and remain above $93^{\circ} \mathrm{C}\left[200^{\circ} \mathrm{F}\right]$ for several days. 
AGING MANAGEMENT GUIDELINE FOR HEAT EXCHANGERS

\begin{tabular}{|c|c|c|c|c|c|c|c|c|c|c|c|c|c|}
\hline \multirow[b]{2}{*}{ Heat Exchanger Component } & \multirow[b]{2}{*}{$\begin{array}{l}\text { Thermal } \\
\text { Embritilement }\end{array}$} & \multirow[b]{2}{*}{$\begin{array}{c}\text { Stress } \\
\text { Relaxation }\end{array}$} & \multirow[b]{2}{*}{ Creep } & \multirow[b]{2}{*}{$\begin{array}{l}\text { Mechanical } \\
\text { Fatigue }\end{array}$} & \multicolumn{4}{|c|}{ Corrosion } & \multicolumn{2}{|c|}{$\begin{array}{l}\text { Stress Corrosion } \\
\text { Cracking }\end{array}$} & \multirow{2}{*}{$\begin{array}{l}\text { Erosion and } \\
\text { Erosion/ } \\
\text { Corrosion }\end{array}$} & \multirow[b]{2}{*}{ Wear } & \multirow[b]{2}{*}{ Fouling } \\
\hline & & & & & General & Pitting & Galvanic & MIC & IGSCC & TGSCC & & & \\
\hline Tubes/Coils & -. & -- & - & $\mathrm{x}$ & -- & -- & -. & -- & $\mathrm{x}$ & - & -- & $\mathrm{x}$ & $\mathbf{x}$ \\
\hline Tube Sheets & -- & -- & -. & $\mathrm{x}$ & -- & -- & -- & - & $\mathrm{x}$ & - & - & $\mathrm{x}$ & $\mathbf{x}$ \\
\hline Shell/Nozzles/Intemals & -- & -- & -- & $\mathrm{x}$ & -- & -- & -- & -- & $\mathrm{x}$ & -- & $\mathbf{x}$ & -- & $\mathrm{x}$ \\
\hline $\begin{array}{l}\text { Waterbox/Channel Head/Divider } \\
\text { Plate }\end{array}$ & -- & -- & -. & $\mathrm{x}$ & -- & -- & & -- & $\mathrm{x}$ & - & -- & -- & $\mathrm{x}$ \\
\hline $\begin{array}{l}\text { Pressure Boundary Fastenersi } \\
\text { Support Assembly }\end{array}$ & -- & $\mathrm{x}$ & -- & -- & $\mathrm{x}$ & -- & -- & -- & -- & -- & -- & -- & -- \\
\hline
\end{tabular}

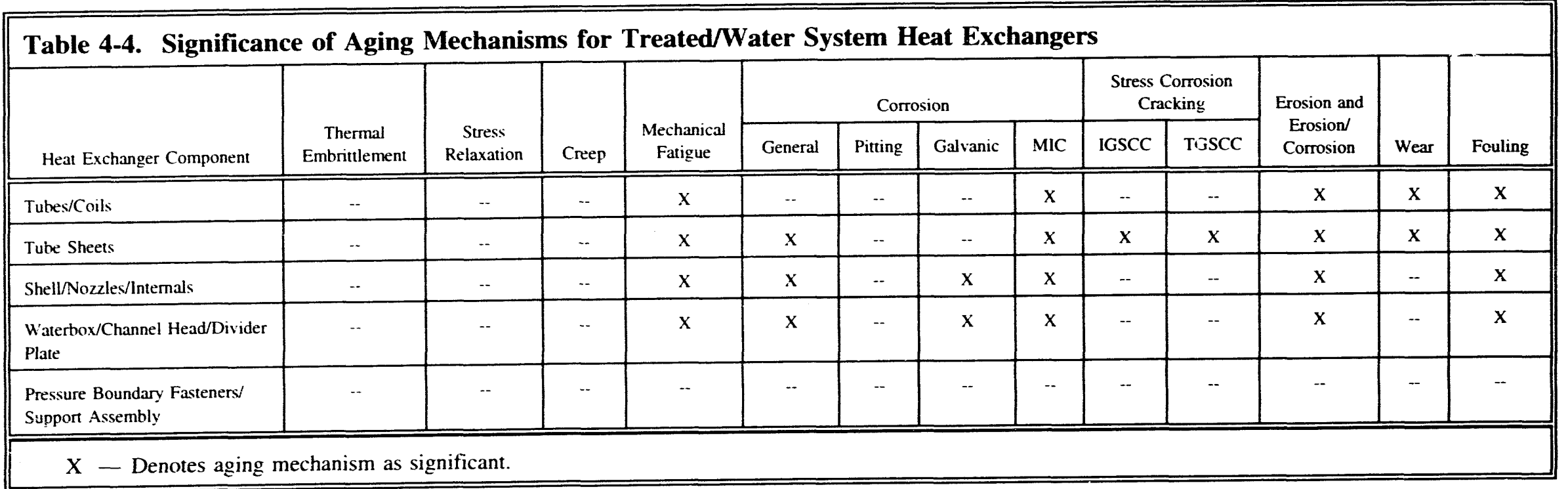


AGING MANAGEMENT GUIDELINE FOR HEAT EXCHANGERS

\begin{tabular}{|c|c|c|c|c|c|c|c|c|c|c|c|c|c|}
\hline \multirow[b]{2}{*}{ Heat Exchanger Component } & \multirow{2}{*}{$\begin{array}{l}\text { Thermal } \\
\text { Embritulement }\end{array}$} & \multirow{2}{*}{$\begin{array}{c}\text { Stress } \\
\text { Relaxation }\end{array}$} & \multirow[b]{2}{*}{ Creep } & \multirow{2}{*}{$\begin{array}{l}\text { Mechanical } \\
\text { Fatigue }\end{array}$} & \multicolumn{4}{|c|}{ Corrosion } & \multicolumn{2}{|c|}{$\begin{array}{l}\text { Stress Corrosion } \\
\text { Cracking }\end{array}$} & \multirow{2}{*}{$\begin{array}{c}\text { Erosion and } \\
\text { Erosion/ } \\
\text { Corrosion }\end{array}$} & \multirow[b]{2}{*}{ Wear } & \multirow[b]{2}{*}{ Fouling } \\
\hline & & & & & General & Pitting & Galvanic & MIC & IGSCC & TGSCC & & & \\
\hline Tuhes/Coils & -- & -. & -- & $\mathrm{x}$ & -- & .. & -- & $\mathrm{x}$ & -- & -- & -. & $\mathrm{x}$ & - \\
\hline Tube Sheets & -. & -- & - & $\mathrm{x}$ & $\mathrm{x}$ & -- & -. & $\mathrm{x}$ & $\mathrm{x}$ & $\mathrm{x}$ & - & $\mathbf{x}$ & -- \\
\hline Shell/Nozzles/Internals & -- & -. & -. & $x$ & $\mathrm{x}$ & -- & .. & $\mathrm{x}$ & -- & - & $\mathrm{x}$ & - & - \\
\hline $\begin{array}{l}\text { Waterbox/Channel Head/Divider } \\
\text { Plate }\end{array}$ & -. & - & $-\cdot$ & $x$ & $\mathrm{x}$ & -- & -- & $\mathrm{x}$ & -- & -- & - & -- & - \\
\hline $\begin{array}{l}\text { Pressure Boundary Fastenersi } \\
\text { Support Assembly }\end{array}$ & -. & -- & -- & -- & -. & -- & -. & -- & - & -- & -- & -- & -- \\
\hline
\end{tabular}

Table 4-6. Significance of Aging Mechanisms for Lubricating Oil System Heat Exchangers

\begin{tabular}{|c|c|c|c|c|c|c|c|c|c|c|c|c|c|}
\hline \multirow[b]{2}{*}{ Heat Exchanger Component } & \multirow[b]{2}{*}{$\begin{array}{l}\text { Thermal } \\
\text { Embrittlement }\end{array}$} & \multirow[b]{2}{*}{$\begin{array}{c}\text { Stress } \\
\text { Relaxation }\end{array}$} & \multirow[b]{2}{*}{ Creep } & \multirow[b]{2}{*}{$\begin{array}{l}\text { Mechanical } \\
\text { Fatigue }\end{array}$} & \multicolumn{4}{|c|}{ Corrosion } & \multicolumn{2}{|c|}{$\begin{array}{l}\text { Stress Corrosion } \\
\text { Cracking }\end{array}$} & \multirow{2}{*}{$\begin{array}{l}\text { Erosion and } \\
\text { Erosion/ } \\
\text { Corrosion }\end{array}$} & \multirow[b]{2}{*}{ Wear } & \multirow[b]{2}{*}{ Fouling } \\
\hline & & & & & General & Pitting & Galvanic & MIC & IGSCC & TGSCC & & & \\
\hline Tubes/Coils & -- & -- & -. & $\mathrm{x}$ & -. & - & - & -- & -- & - & -- & $\mathbf{x}$ & $\mathrm{x}$ \\
\hline Tube Sheets & - & -- & -. & $x$ & - & -- & -- & -- & -- & -- & -- & $x$ & $\mathrm{x}$ \\
\hline Shell/Nozzles/Internals & $-\cdot$ & $-\cdot$ & -- & $x$ &.- & - & -- & -- & -. & -- & - & - & $\mathrm{x}$ \\
\hline $\begin{array}{l}\text { Waterbox/Channel Head/Divider } \\
\text { Plate }\end{array}$ & -- & -- & - & $\mathrm{x}$ & -- & -- & -- & -- & -- & - & -- & -- & -- \\
\hline $\begin{array}{l}\text { Pressure Boundary Fasteners/ } \\
\text { Suppor Assembly }\end{array}$ & -- & -- & - & - & -- & -- & -- & -- & -- & -- & -- & -- & -- \\
\hline
\end{tabular}


AGING MANAGEMENT GUIDELINE FOR HEAT EXCHANGERS

\begin{tabular}{|c|c|c|c|c|c|c|c|c|c|c|c|c|c|}
\hline \multirow[b]{2}{*}{ Heat Exchanger Component } & \multirow[b]{2}{*}{$\begin{array}{c}\text { Thermal } \\
\text { Embrittlement }\end{array}$} & \multirow[b]{2}{*}{$\begin{array}{c}\text { Stress } \\
\text { Relaxation }\end{array}$} & \multirow[b]{2}{*}{ Creep } & \multirow[b]{2}{*}{$\begin{array}{l}\text { Mechanical } \\
\text { Fatigue }\end{array}$} & \multicolumn{4}{|c|}{ Corrosion } & \multicolumn{2}{|c|}{$\begin{array}{l}\text { Stress Corrosion } \\
\text { Cracking }\end{array}$} & \multirow{2}{*}{$\begin{array}{c}\text { Erosion and } \\
\text { Erosion/ } \\
\text { Corrosion }\end{array}$} & \multirow[b]{2}{*}{ Wear } & \multirow[b]{2}{*}{ Fouling } \\
\hline & & & & & General & Pitting & Galvanic & MIC & IGSCC & TGSCC & & & \\
\hline Tubes/Coils & -- & -- & - & $\mathrm{x}$ & $\mathrm{x}$ & $\mathrm{x}$ & - & $\mathrm{x}$ & $\mathrm{x}$ & -- & $\mathrm{x}$ & $x$ & $\mathrm{x}$ \\
\hline Tube Sheets & - & -- & -- & $\mathrm{x}$ & $\mathrm{x}$ & $\mathrm{x}$ & -- & $\mathrm{x}$ & $\mathrm{x}$ & $\mathrm{x}$ & $\mathrm{x}$ & $\mathrm{x}$ & $\mathrm{x}$ \\
\hline Shell/Nozzles/Internals & - & -- & - & $x$ & -- & -- & -- &.- & - & -- & -- & - & $\mathrm{x}$ \\
\hline $\begin{array}{l}\text { Waterbox/Channel Head/Divider } \\
\text { Plate }\end{array}$ & -- & -- & -- & $\mathrm{x}$ & $\mathrm{x}$ & $\mathrm{x}$ & $\mathrm{x}$ & $\mathrm{x}$ & $\mathrm{x}$ & - & $\mathrm{x}$ & - & $\mathrm{x}$ \\
\hline $\begin{array}{l}\text { Pressure Boundary Fasteners/ } \\
\text { Suppor Assembly }\end{array}$ & -- & -- & -- & - & -- & $x$ & -- & -- & -- & -- & -- & -- & -- \\
\hline
\end{tabular}

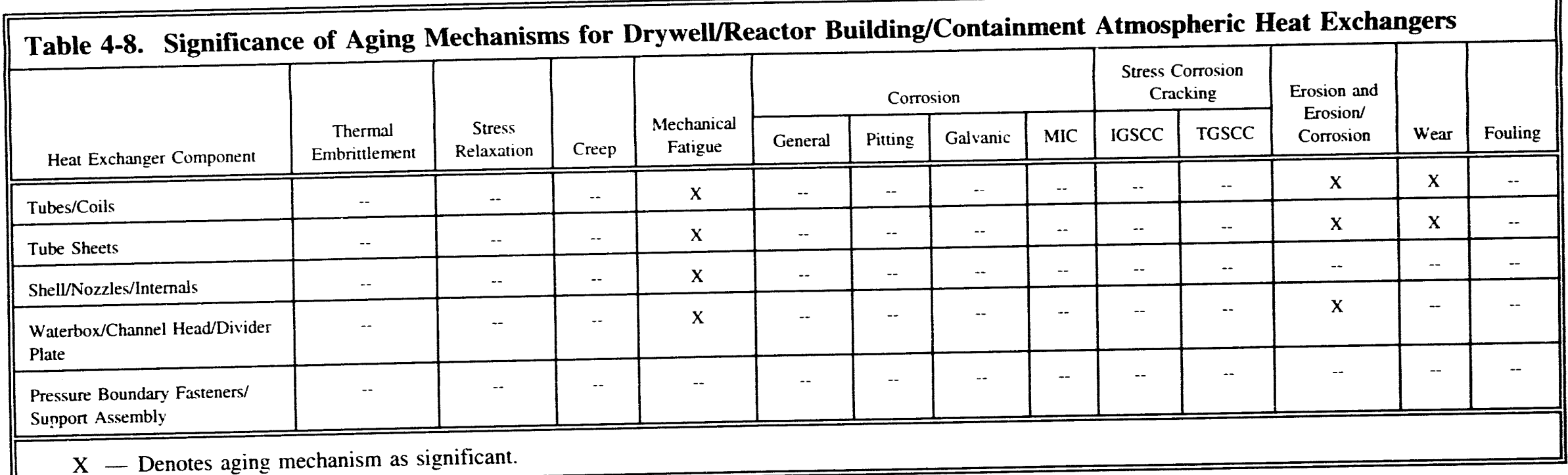




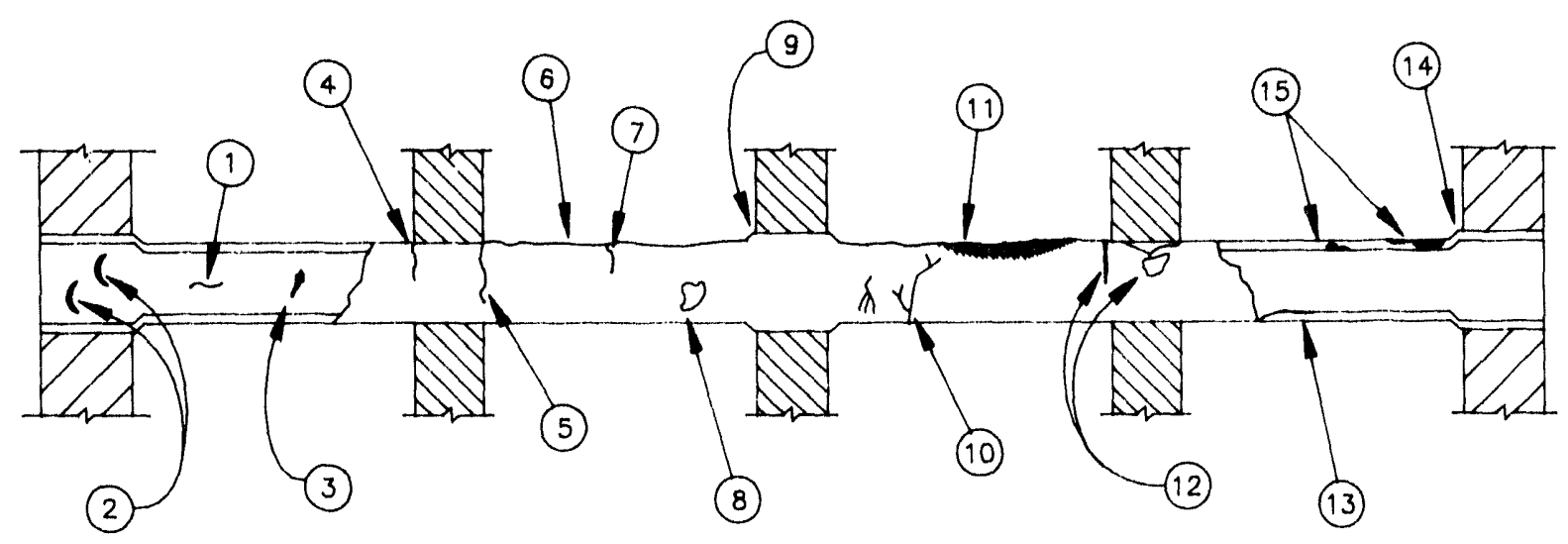

1. Inlet erosion and uniform wastage

2. Cavitation and erosion pitting

3. Debris or "clamshell" pits

4. Support wear

5. Fatigue cracks

\author{
6. Tube-to-tube wear \\ 7. Midspan fatigue cracks \\ 8. Dealloying \\ 9. Overrolling or freeze bulges \\ 10. Stress corrosion cracking \\ 11. Steam erosion \\ 12. Corrosion at supports
}

13. Deposit-type pitting and electromechanical corrosion filling

14. Overrolling at tubesheet

15. Manufacturing defects

Figure 4-3. Common Heat Exchanger Tube Degradation.

The RWCU non-regenerative heat exchangers operate at reactor temperatures $288^{\circ} \mathrm{C}\left[550^{\circ} \mathrm{F}\right]$ for short time periods when the regenerative heat exchangers upstream are bypassed. The duration of bypass mode operation is limited to a few days while regenerative heat exchanger degradation/ failure is corrected.

If the RHR heat exchangers (for both BWR and PWR plants) and the RWCU nonregenerative heat exchangers operate at temperatures above $93^{\circ} \mathrm{C}\left[200^{\circ} \mathrm{F}\right]$ for short time durations as described above, then thermal embrittlement, stress relaxation, and creep are not significant aging mechanisms.

Stress relaxation and creep are similar phenomena. At elevated temperatures, a material subject to constant stress below its yield strength will flow plastically and permanently change dimension in the direction of the stress. This is defined as creep. In a joint at elevated temperature, a fastener (i.e., bolt or stud) with a fixed distance between the bearing surfaces of the male and female members will produce less and less clamping force over a period of time. This is called stress relaxation and differs from creep in that the stress level changes while elongation or strain remains constant. Therefore, if the heat exchanger component is a fastener continuously exposed to temperatures greater than $93^{\circ} \mathrm{C}\left[200^{\circ} \mathrm{F}\right]$ (i.e., BWR RWCU regenerative heat exchangers and PWR Chemical and Volume Control (CVC) regenerative, letdown, excess letdown, and seal water heat exchangers), then stress relaxation is a significant aging mechanism because the fastener will provide less and less clamping force over a period of time. These conditions are further examined in Section 4.3.2.5. Stress relaxation is not a significant aging mechanism for all other heat exchanger components. 
The regenerative heat exchangers located in the BWR RWCU system are supplied directly from the Reactor Recirculation System at reactor coolant temperatures of approximately $288^{\circ} \mathrm{C}$ $\left[550^{\circ} \mathrm{F}\right]$. In PWR plants, the Chemical and Volume Control System (CVCS) heat exchangers (i.e., regenerative, letdown, and excess letdown seal water) all continuously operate at temperatures greater than $93^{\circ} \mathrm{C}\left[200^{\circ} \mathrm{F}\right]$. Therefore, thermal embrittlement and creep are further examined in Section 4.3.2 for these heat exchangers.

All other heat exchanger applications operate at temperature below $93^{\circ} \mathrm{C}\left[200^{\circ} \mathrm{F}\right]$ unless there is a transient event or an event involving operator error. These occurrences are relatively short-term situations and not attributable to aging. Thermal embrittlement, and creep are not significant aging mechanisms for these remaining heat exchangers.

\subsubsection{Irradiation Assisted Stress Corrosion Cracking (IASCC) and Neutron Embrittlement}

Except for BWR drywell coolers and PWR containment coolers, the remaining heat exchanger's evaluated in this AMG are located outside Primary Containment. Heat exchangers outside Primary Containment are exposed to very low levels of neutron fluence from external sources.

The PWR CVC regenerative, letdown, and excess letdown heat exchangers, BWR RWCU regenerative and non-regenerative heat exchangers, RHR heat exchangers, and fuel pool cooling heat exchangers may be exposed to neutron fluence from the fluid following a fuel assembly failure. There were no heat exchanger failures from IASCC or neutron embrittlement reported in the review of plant operating history in Section 3. From other aging studies, a 40-year maximum fast neutron fluence (energy $>1 \mathrm{MeV}$ ) for the reactor vessel beltine region is estimated to be $3.6 \times 10^{18} \mathrm{n} / \mathrm{cm}^{2}$ [4.19]. Projected forward to 60 years, the maximum fast neutron fluence at the reactor vessel beltline region is calculated as $5.4 \times 10^{18} \mathrm{n} / \mathrm{cm}^{2}$. Assuming an $80 \%$ capacity factor for 60 years of plant operation, the maximum fast neutron fluence at the outside surface of the containment wall is estimated to be between $4 \times 10^{14}$ to $3 \times 10^{15} \mathrm{n} / \mathrm{cm}^{2}$ [4.20]. These fast neutron fluence levels are more than 100 times lower than levels necessary to initiate these aging mechanisms (see Sections 4.2 .3 and 4.2.5).

The other heat exchangers in the scope of this AMG can not be subjected to fast neutron fluence from internal sources. Therefore, IASCC and neutron embrittlement are not significant aging mechanisms for all heat exchangers without additional conditions.

\subsubsection{Thermal Fatigue}

Thermal stress is a self balancing stress produced by a non-uniform distribution of temperature. A temperature change of the fluid results in a non-uniform temperature distribution in the heat exchanger wetted components/parts. The range of fluid temperature levels are shown in Tables 4-9 and 4-10 for each of the heat exchangers. The minimum, normal, and maximum operating temperatures are steady-state operating conditions for the planned operating modes of the respective systems. 
AGING MANAGEMENT GUIDELINE FOR HEAT EXCHANGERS

\begin{tabular}{|c|c|c|c|c|c|c|c|c|}
\hline \multirow[b]{2}{*}{ BWR Heat Exchangers } & \multirow{2}{*}{$\begin{array}{l}\text { Normal } \\
\text { Operating } \\
\text { Status }\end{array}$} & \multirow{2}{*}{$\begin{array}{c}\text { Minimum } \\
\text { Nominal } \\
\text { Operating } \\
\text { Temperature }\end{array}$} & \multirow{2}{*}{$\begin{array}{l}\text { Nominal } \\
\text { Operating } \\
\text { Temperature }\end{array}$} & \multirow{2}{*}{$\begin{array}{l}\text { Maximum } \\
\text { Nominal } \\
\text { Operating } \\
\text { Temperature }\end{array}$} & \multicolumn{2}{|c|}{$\begin{array}{c}\text { Subject to Start-up/Shutdown } \\
\text { Thermal Cycles }\end{array}$} & \multicolumn{2}{|c|}{$\begin{array}{l}\text { Subject to Thermal Cycles } \\
\text { from Plant Transients }\end{array}$} \\
\hline & & & & & Yes/No & $\operatorname{Max} . \Delta \mathrm{T}^{*}$ & Yes/No & $\operatorname{Max} . \Delta \mathrm{T}^{*}$ \\
\hline Closed Cooling Water & Continuous & $27^{\circ} \mathrm{C}\left[80^{\circ} \mathrm{F}\right]$ & $<35^{\circ} \mathrm{C}\left[95^{\circ} \mathrm{F}\right]$ & $35^{\circ} \mathrm{C}\left[95^{\circ} \mathrm{F}\right]$ & Yes & $8.3^{\circ} \mathrm{C}\left[15^{\circ} \mathrm{F}\right]$ & No & N/A \\
\hline Drywell Coolers & Continuous & $21^{\circ} \mathrm{C}\left[70^{\circ} \mathrm{F}\right]$ & $<57^{\circ} \mathrm{C}\left[135^{\circ} \mathrm{F}\right]$ & $<66^{\circ} \mathrm{C}\left[150^{\circ} \mathrm{F}\right]$ & Yes & $36.1^{\circ} \mathrm{C}\left[65^{\circ} \mathrm{F}\right]$ & Yes & $111^{\circ} \mathrm{C}\left[200^{\circ} \mathrm{F}\right]$ \\
\hline ECCS Room Coolers & Standby & $21^{\circ} \mathrm{C}\left[70^{\circ} \mathrm{F}\right]$ & $<35^{\circ} \mathrm{C}\left[95^{\circ} \mathrm{F}\right]$ & $<49^{\circ} \mathrm{C}\left[120^{\circ} \mathrm{F}\right]$ & No & N/A & Yes & $61^{\circ} \mathrm{C}\left[110^{\circ} \mathrm{F}\right]$ \\
\hline $\begin{array}{l}\text { Emergency Diesel Generator } \\
\text { Jacket Water }\end{array}$ & Standby & $27^{\circ} \mathrm{C}\left[80^{\circ} \mathrm{F}\right]$ & $<35^{\circ} \mathrm{C}\left[95^{\circ} \mathrm{F}\right]$ & $<35^{\circ} \mathrm{C}\left[95^{\circ} \mathrm{F}\right]$ & Yes & $8.3^{\circ} \mathrm{C}\left[15^{\circ} \mathrm{F}\right]$ & No & N/A \\
\hline $\begin{array}{l}\text { Emergency Diesel Generator } \\
\text { Lubrication Oil }\end{array}$ & Continuous & $10^{\circ} \mathrm{C}\left[50^{\circ} \mathrm{F}\right]$ & $\approx 38^{\circ} \mathrm{C}\left[100^{\circ} \mathrm{F}\right]$ & $66^{\circ} \mathrm{C}\left[150^{\circ} \mathrm{F}\right]$ & Yes & $27.8^{\circ} \mathrm{C}\left[50^{\circ} \mathrm{F}\right]$ & No & $\mathrm{N} / \mathrm{A}$ \\
\hline $\begin{array}{l}\text { High Pressure Coolant } \\
\text { Injection Gland Seal } \\
\text { Condenser }\end{array}$ & Standby & $4^{\circ} \mathrm{C}\left[40^{\circ} \mathrm{F}\right]$ & $<35^{\circ} \mathrm{C}\left[95^{\circ} \mathrm{F}\right]$ & $<35^{\circ} \mathrm{C}\left[95^{\circ} \mathrm{F}\right]$ & Yes & $16.7^{\circ} \mathrm{C}\left[30^{\circ} \mathrm{F}\right]$ & Yes & $78^{\circ} \mathrm{C}\left[140^{\circ} \mathrm{F}\right]$ \\
\hline $\begin{array}{l}\text { High Pressure Coolant } \\
\text { Injection Lube Oil Cooler }\end{array}$ & Standby & $4^{\circ} \mathrm{C}\left[40^{\circ} \mathrm{F}\right]$ & $<35^{\circ} \mathrm{C}\left[95^{\circ} \mathrm{F}\right]$ & $<35^{\circ} \mathrm{C}\left[95^{\circ} \mathrm{F}\right]$ & Yes & $16.7^{\circ} \mathrm{C}\left[30^{\circ} \mathrm{F}\right]$ & Yes & $78^{\circ} \mathrm{C}\left[140^{\circ} \mathrm{F}\right]$ \\
\hline $\begin{array}{l}\text { Reactor Core Isolation Cooling } \\
\text { Lube Oil Cooler }\end{array}$ & Standby & $4^{\circ} \mathrm{C}\left[40^{\circ} \mathrm{F}\right]$ & $<35^{\circ} \mathrm{C}\left[95^{\circ} \mathrm{F}\right]$ & $<35^{\circ} \mathrm{C}\left[95^{\circ} \mathrm{F}\right]$ & Yes & $16.7^{\circ} \mathrm{C}\left[30^{\circ} \mathrm{F}\right]$ & Yes & $78^{\circ} \mathrm{C}\left[140^{\circ} \mathrm{F}\right]$ \\
\hline $\begin{array}{l}\text { Reactor Water Cleanup Non- } \\
\text { Regenerative }\end{array}$ & Continuous & $21^{\circ} \mathrm{C} \mid 70^{\circ} \mathrm{Fl}$ & $\leq 60^{\circ} \mathrm{C}\left[140^{\circ} \mathrm{F}\right]$ & $<60^{\circ} \mathrm{C}\left[140^{\circ} \mathrm{F}\right]$ & Yes & $38.9^{\circ} \mathrm{C}\left[70^{\circ} \mathrm{F}\right]$ & Yes & $233^{\circ} \mathrm{C}\left[420^{\circ} \mathrm{F}\right]$ \\
\hline $\begin{array}{l}\text { Reactor Water Cleanup } \\
\text { Regenerative }\end{array}$ & Continuous & $21^{\circ} \mathrm{C}\left(70^{\circ} \mathrm{F}\right]$ & $293^{\circ} \mathrm{C}\left[560^{\circ} \mathrm{F}\right]$ & $293^{\circ} \mathrm{C}\left[560^{\circ} \mathrm{F}\right]$ & Yes & $272^{\circ} \mathrm{C}\left[490^{\circ} \mathrm{F}\right]$ & No & $\mathrm{N} / \mathrm{A}$ \\
\hline Residual Heat Removal & Standby & $4^{\circ} \mathrm{C}\left[40^{\circ} \mathrm{F}\right]$ & $35^{\circ} \mathrm{C}\left[95^{\circ} \mathrm{F}\right]$ & $177^{\circ} \mathrm{C}\left[350^{\circ} \mathrm{F}\right]$ & Yes & $141^{\circ} \mathrm{C}\left[255^{\circ} \mathrm{F}\right]$ & Yes & $141^{\circ} \mathrm{C}\left[255^{\circ} \mathrm{F}\right]$ \\
\hline Spent Fuel Pool & Continuous & $27^{\circ} \mathrm{C}\left[80^{\circ} \mathrm{F}\right]$ & $\approx 27^{\circ} \mathrm{C}\left[80^{\circ} \mathrm{F}\right]$ & $66^{\circ} \mathrm{C}\left[150^{\circ} \mathrm{F}\right]$ & No & N/A & No & N/A \\
\hline
\end{tabular}




\section{AGING MANAGEMENT GUIDELINE FOR HEAT EXCHANGERS}

\begin{tabular}{|c|c|c|c|c|c|c|c|c|}
\hline \multirow[b]{2}{*}{ PWR Heat Exchangers } & \multirow{2}{*}{$\begin{array}{l}\text { Normal } \\
\text { Operating } \\
\text { Status }\end{array}$} & \multirow{2}{*}{$\begin{array}{c}\text { Minimum } \\
\text { Nominal } \\
\text { Operating } \\
\text { Temperature }\end{array}$} & \multirow{2}{*}{$\begin{array}{c}\text { Nominal } \\
\text { Operating } \\
\text { Temperature }\end{array}$} & \multirow{2}{*}{$\begin{array}{c}\text { Maximum } \\
\text { Nominal } \\
\text { Operating } \\
\text { Temperature }\end{array}$} & \multicolumn{2}{|c|}{$\begin{array}{l}\text { Subject to Start-up/ } \\
\text { Shutdown Thermal Cycles }\end{array}$} & \multicolumn{2}{|c|}{$\begin{array}{l}\text { Subject to Theimal Cycles } \\
\text { from Plant Transients }\end{array}$} \\
\hline & & & & & Yes/No & Max. $\Delta \mathrm{T}$ & Yes/No & $\operatorname{Max} . \Delta \mathrm{T}$ \\
\hline CVCS Excess Letdown & Continuous & $32^{\circ} \mathrm{C}\left[90^{\circ} \mathrm{F}\right]$ & $290^{\circ} \mathrm{C}\left[555^{\circ} \mathrm{F}\right]$ & $299^{\circ} \mathrm{C}\left[570^{\circ} \mathrm{F}\right]$ & Yes & $278^{\circ} \mathrm{C}\left[500^{\circ} \mathrm{F}\right]$ & No & N/A \\
\hline CVCS Letdown & Continuous & $27^{\circ} \mathrm{C}\left[80^{\circ} \mathrm{F}\right]$ & $149^{\circ} \mathrm{C}\left[300^{\circ} \mathrm{F}\right]$ & $193^{\circ} \mathrm{C}\left[380^{\circ} \mathrm{F}\right]$ & Yes & $172^{\circ} \mathrm{C}\left[310^{\circ} \mathrm{F}\right]$ & Yes & $111^{\circ} \mathrm{C}\left[200^{\circ} \mathrm{F}\right]$ \\
\hline CVCS Regenerative & Continuous & $54^{\circ} \mathrm{C}\left[130^{\circ} \mathrm{F}\right]$ & $288^{\circ} \mathrm{C}\left[550^{\circ} \mathrm{F}\right]$ & $\leq 316^{\circ} \mathrm{C}\left[600^{\circ} \mathrm{F}\right]$ & Yes & $256^{\circ} \mathrm{C}\left[460^{\circ} \mathrm{F}\right]$ & No & N/A \\
\hline CVCS Seal Water & Continuous & $35^{\circ} \mathrm{C}\left[95^{\circ} \mathrm{F}\right]$ & $49^{\circ} \mathrm{C}\left[120^{\circ} \mathrm{F}\right]$ & $71^{\circ} \mathrm{C}\left[160^{\circ} \mathrm{F}\right]$ & Yes & $50^{\circ} \mathrm{C}\left[90^{\circ} \mathrm{F}\right]$ & No & N/A \\
\hline Closed Cooling Water & Continuous & $27^{\circ} \mathrm{C}\left[80^{\circ} \mathrm{F}\right]$ & $<35^{\circ} \mathrm{C}\left[95^{\circ} \mathrm{F}\right]$ & $35^{\circ} \mathrm{C}\left[95^{\circ} \mathrm{F}\right]$ & Yes & $8.3^{\circ} \mathrm{C}\left[15^{\circ} \mathrm{F}\right]$ & No & N/A \\
\hline Containment Coolers & Continuous & $21^{\circ} \mathrm{C}\left[70^{\circ} \mathrm{F}\right]$ & $27^{\circ} \mathrm{C}\left[80^{\circ} \mathrm{F}\right]$ & $43^{\circ} \mathrm{C}\left[110^{\circ} \mathrm{F}\right]$ & No & N/A & Yes & $67^{\circ} \mathrm{C}\left[120^{\circ} \mathrm{F}\right]$ \\
\hline $\begin{array}{l}\text { Emergency Diesel } \\
\text { Generator Jacket Water }\end{array}$ & Standby & $27^{\circ} \mathrm{C}\left[80^{\circ} \mathrm{F}\right]$ & $<35^{\circ} \mathrm{C}\left[95^{\circ} \mathrm{F}\right]$ & $<35^{\circ} \mathrm{C}\left[95^{\circ} \mathrm{F}\right]$ & Yes & $8.3^{\circ} \mathrm{C}\left[15^{\circ} \mathrm{F}\right]$ & No & N/A \\
\hline $\begin{array}{l}\text { Emergency Diesel } \\
\text { Generator Lubricating Oil }\end{array}$ & Continuous & $10^{\circ} \mathrm{C}\left[50^{\circ} \mathrm{F}\right]$ & $=38^{\circ} \mathrm{C}\left[100^{\circ} \mathrm{F}\right]$ & $66^{\circ} \mathrm{C}\left[150^{\circ} \mathrm{F}\right]$ & Yes & $27.8^{\circ} \mathrm{C}\left[50^{\circ} \mathrm{F}\right]$ & No & N/A \\
\hline Residual Heat Removal & Standby & $21^{\circ} \mathrm{C}\left[70^{\circ} \mathrm{F}\right]$ & $35^{\circ} \mathrm{C}\left[95^{\circ} \mathrm{F}\right]$ & $177^{\circ} \mathrm{C}\left[350^{\circ} \mathrm{F}\right]$ & Yes & $141^{\circ} \mathrm{C}\left[255^{\circ} \mathrm{F}\right]$ & Yes & $141^{\circ} \mathrm{C}\left[255^{\circ} \mathrm{F}\right]$ \\
\hline Spent Fuel Pool Cooling & Continuous & $27^{\circ} \mathrm{C}\left[80^{\circ} \mathrm{F}\right]$ & $\approx 27^{\circ} \mathrm{C}\left[80^{\circ} \mathrm{F}\right]$ & $66^{\circ} \mathrm{C}\left[150^{\circ} \mathrm{F}\right]$ & No & N/A & No & N/A \\
\hline
\end{tabular}



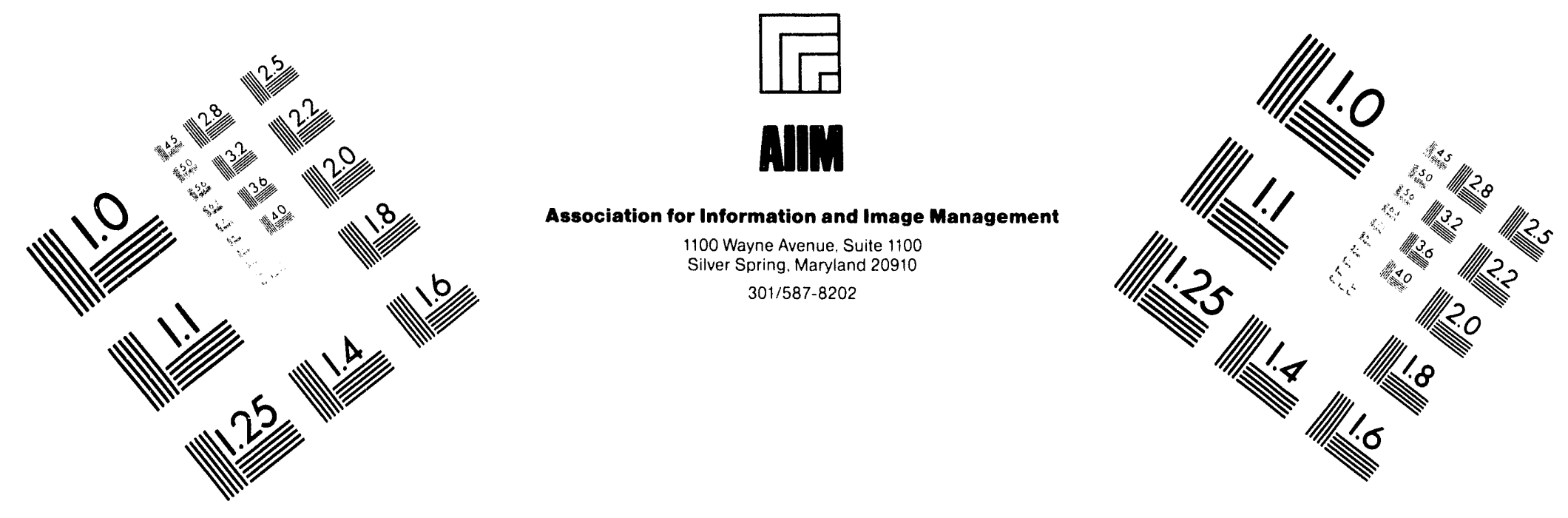

\section{Centimeter}

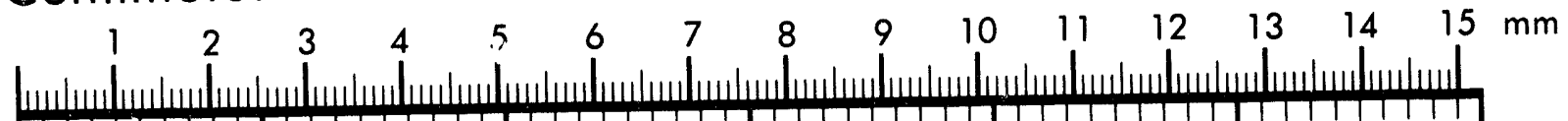

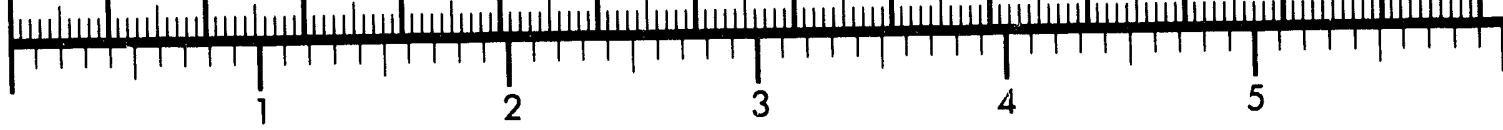
Inches
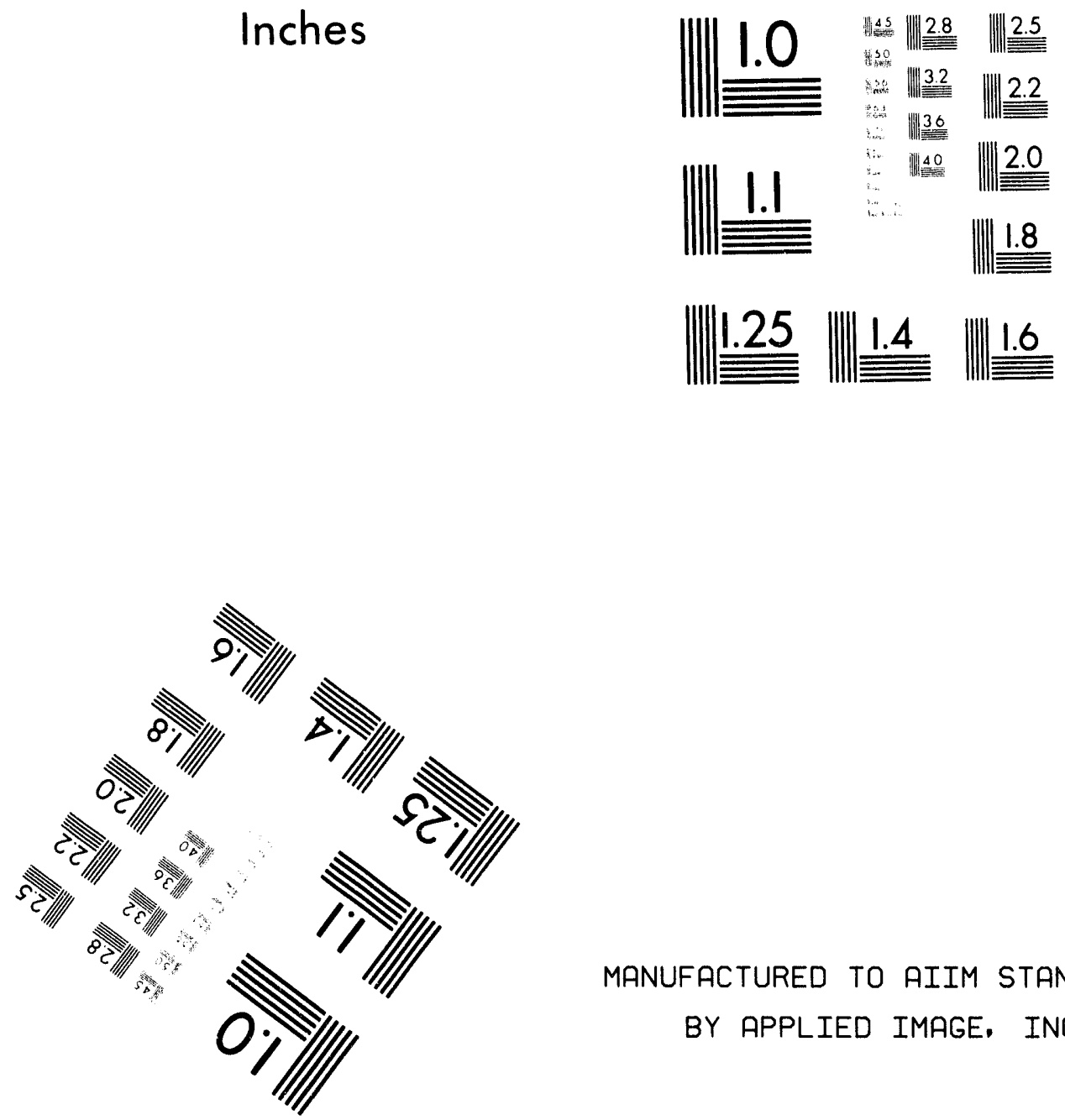

MANUFACTURED TO AIIM STANDARDS

BY APPLIED IMAGE, INC.

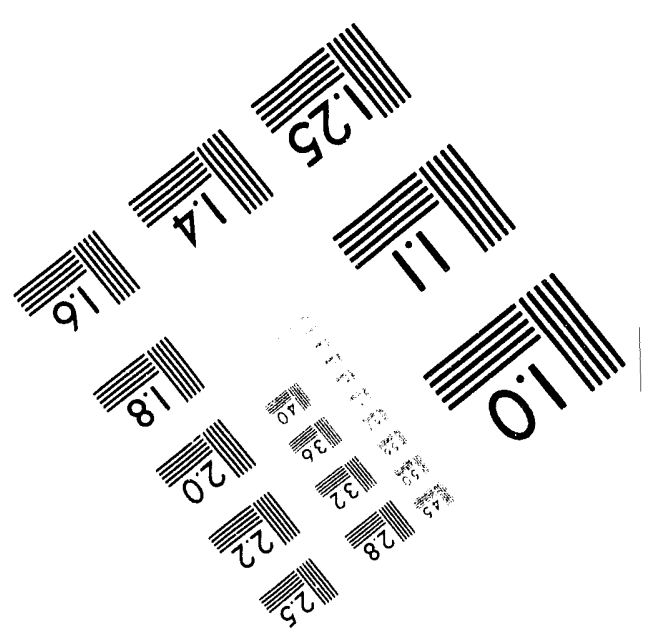



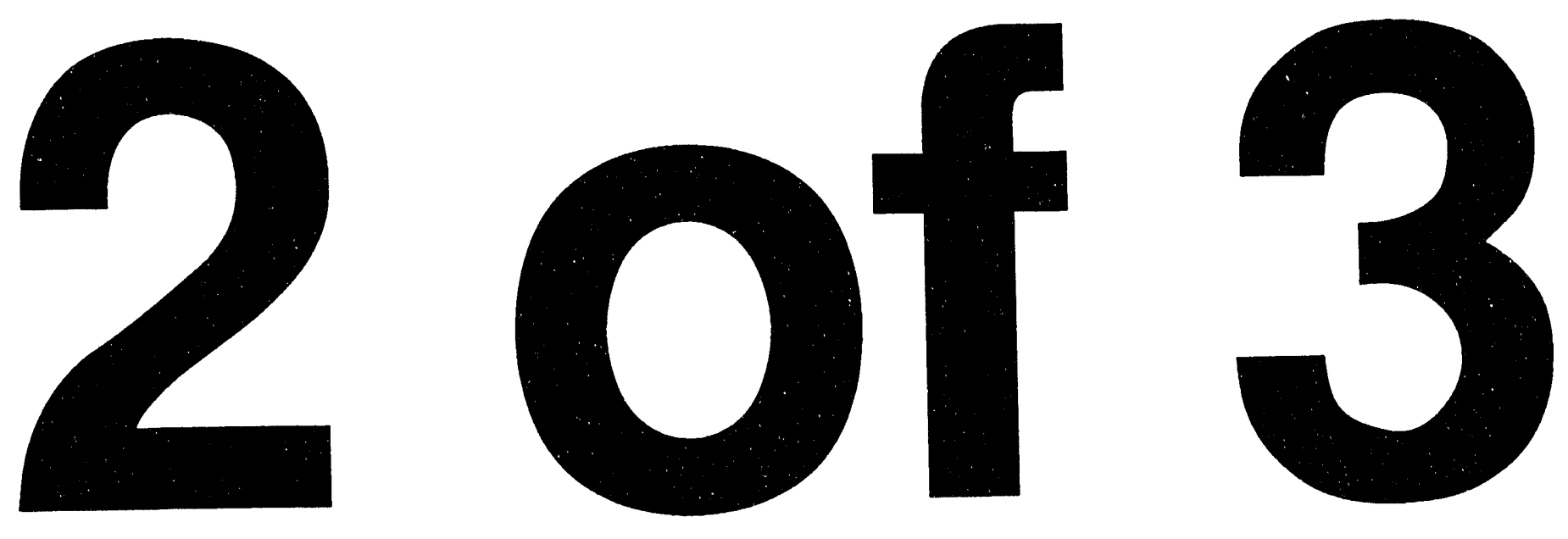
The start-up and shutdown thermal cycles are associated with operating the system during normal plant operating conditions. Many of the heat exchangers are maintained in a standby condition. When the heat exchangers are placed into service, the temperature changes from the local ambient temperature to the fluid operating temperature. The values of "Max. $\Delta \mathrm{T}$ " shown in Tables 4-9 and 4-10 were determined for a local ambient temperature of $21^{\circ} \mathrm{C}\left[70^{\circ} \mathrm{F}\right]$. The temperature changes are relatively small, except for the RHR heat exchangers, RWCU regenerative heat exchangers, and C.VC regenerative, letdown, and excess letdown heat exchangers. The associated thermal stresses are, therefore, small and would not be a consideration for heat exchanger design and operation. System design features and operating requirements are used to control the rate of temperature change for the RHR heat exchangers, RWCU regenerative heat exchangers, and CVC regenerative, letdown, and excess letdown heat exchangers during normal plant operation. These features and requirements ensure that during normal plant operation the rate of change is less than $55^{\circ} \mathrm{C}\left[100^{\circ} \mathrm{F} / \mathrm{hr}\right]$. With these controls, the cumulative fatigue usage due to thermal cycles is negligible and not a consideration for heat exchanger design and operation.

Some of the heat exchangers are subject to thermal cycles from plant transients (Tables 4-9 and 4-10). With the exception of the reactor water cleanup non-regenerative heat exchangers, these transients are associated with postulated accident conditions. The design assumes a very low number of accident occurrences and therefore the number of thermal cycles caused by accident conditions is very small. Consequently, cumulative fatigue usage due to accident conditions is low, and therefore not a consideration for heat exchanger design and operation. The reactor water cleanup non-regenerative heat exchangers, however, would be subject to a significant thermal cycle (i.e., $>111^{\circ} \mathrm{C} / \mathrm{hr}\left[200^{\circ} \mathrm{F} / \mathrm{hr}\right]$ ) during some plant transients (e.g., failed regenerative heat exchanger). These transients are low occurrence events that are mitigated by good maintenance and plant operating practices. Consequently, cumulative fatigue usage due to transients is low for the non-regenerative heat exchangers and therefore, not a consideration for this heat exchanger design and operation.

Another source of stress results from thermal expansion of the piping connected to the heat exchanger nozzles. The heat exchanger is typically designed to expand with temperature increases. Furthermore, piping system design practices defined in ANSI B31.1 and ASME Section III limit the loads applied to the heat exchanger from thermal expansion of the piping. The flexibility of the piping is designed to ensure that the maximum allowable heat exchanger nozzle loads are not exceeded. Conventional design practices also use conservative assumptions of temperature conditions when determining the nozzle loads. In some cases, the piping design includes expansion loops or expansion joints to achieve acceptable nozzle loading conditions. In some cases, cold spring of the piping may be utilized to counteract stresses applied during heatup to operating temperature. These are rare occurrences and generally are avoided if at all possible. Therefore, stresses imposed on the heat exchanger nozzles from the connected piping are low and not a consideration for the continued operation of the heat exchanger.

These discussions demonstrate that thermal fatigue is not a significant aging mechanism if the following conditions are met.

a. The circulating fluid temperature conditions in Tables 4-9 and 4-10 apply, or are bounding. 
b. System design features and/or operating requirements limit the rate of temperature change to less than $55^{\circ} \mathrm{C} / \mathrm{hr}\left[100^{\circ} \mathrm{F} / \mathrm{hr}\right]$ during normal start-up/shutdown of the RHR heat exchangers (i.e., decay heat removal), CVC system heat exchangers (i.e., regenerative, letdown, and excess letdown) and RWCU heat exchangers (i.e., regenerative and non-regenerative).

c. RWCU regenerative heat exchanger degradation/failure is a limited occurrence event (so the non-regenerative heat exchangers are not exposed to elevated temperature).

d. The loads imposed on the heat exchanger from the connected piping are less than the manufacturer's allowable loads as determined by analysis or measurement.

\subsubsection{Mechanical Fatigue}

Cyclic loads are applied to heat exchanger subassemblies when the unit is placed into service and removed from service (isolated), when undergoing load changes, and when operating under steady state conditions. These loads are caused by mechanical stressors (flow induced vibration) and hydraulic stressors (fluid impingement and differential pressure).

The heat exchanger tubes and lube sheet assembly are subject to the most severe mechanical and hydraulic stressors from both the process and cooling fluid streams. The tubes are rolled or expanded against the tube sheet to create a tight seal. Consequently, this tube-totube sheet joint will contain residual mechanical stress. Additional mechanical and hydraulic stress, applied from the process and cooling fluid streams, may cause this tube-to-tube sheet joint to fail from mechanical fatigue. Inside the shell portion of the heat exchanger, the tubes pass through partitions/bafiles. This tube-to-partition joint is also subject to mechanical and hydraulic stress from the process and cooling fluid streams. Industry experience confirms that this joint is susceptible to mechanical fatigue failure.

All other heat exchanger subassemblies are subject to some level of cyclic loading from induced mechanical and hydraulic stress (see Table 4-1). Industry experience, however, indicates that fatigue failure of these heat exchanger subassemblies is not likely to occur provided the heat exchanger is constructed and operated within specified limits.

Peak stresses generally occur on the exterior surface of a component at a mechanical or metallurgical stress riser. Mechanical stress risers are caused by geometry (small fillets, sharp corners, and grooves), configuration (expanded tube ends), or mechanical abuse (nicks or scratches). Metallurgical stress risers are caused by weld cracks/inclusions, base metal surface flaws, non-homogeneous chemical composition, and residual heat treatment/fabrication stresses. Mechanical stress risers are unavoidable in the design of some heat exchanger components, and the potential for fatigue degradation is always a design consideration.

There are no metals which are immune to fatigue, but some alloys are more resistant than others (more cycles allowed for a given level of alternating stress level/higher endurance limits). Stainless and high alloy steels, for example, are generally less susceptible to low cycle fatigue than carbon and low alloy steels. Since resistance to fatigue is similar to resistance in 
microscopic cracking while undergoing high localized strain rates, materials with greater ductility tend to be less susceptible to fatigue cracking.

These considerations are further examined in Section 4.3.2 for the affected heat exchanger subassemblies and components.

\subsubsection{Corrosion}

Significance of the corrosion aging mechanism is generally associated with the aggressiveness of the environment and characteristics of the materials of construction. For heat exchanger applications included in this AMG, a variety of metals ranging from stainless steel and titanium to copper and carbon steel are utilized (Table 3-3). These heat exchangers are exposed to many different environments (Section 3.4). The generic considerations related to corrosion significance are discussed in terms of four distinct forms of corrosion (general, pitting, galvanic, and microbiologically influenced) in the following paragraphs. Due to the unique nature of the process and cooling fluid environments, specific considerations related to corrosion significance determinations are discussed in Section 4.3.2.

\subsection{General Corrosion}

General corrosion is manifested in two ways; uniform corrosion is where wastage or removal of material has occurred over a large portion of the component surface area; local corrosion is where wastage or removal of material has occurred over a very small portion of the component surface area and may take the form of pits or cracks. Local corrosion is generally caused by non-homogeneous metallurgical characteristics at the material's surface and/or a concentration of fluid contaminants at certain locations.

General corrosion of ferrous materials in aqueous environments is primarily associated with the type and amount of alloy constituents, the aggressiveness of the water ( $\mathrm{pH}$, oxygen content, and chemical contaminants) and exposure time. Although high dissolved oxygen levels generally increase uniform corrosion rates, extremely low oxygen levels (less than 5 pp) may increase rates for materials whose corrosion resistance is dependent on the formation of a tightly adhering oxide layer over the entire surface. The potential for local corrosion is increased for geometries that contain small openings or spaces where fluid is relatively stagnant and may contain higher levels of fluid contaminants than the average in the bulk fluid. In a similar manner, unintentional crevices such as cracks, seams, or grooves could serve as sites for local corrosion initiation.

If the heat exchanger components are made from carbon or low alloy stecl materials and exposed to treated water, raw service water, or closed cooling water service applications, then general corrosion is a significant aging mechanism. These considerations are further examined in Section 4.3.2.

Stainless and other high alloy steel materials which contain $12 \%$ or more chromium have excellent resistance to general corrosion $[4.11]$ for all fluid applications except raw water. Therefore, if the heat exchanger components are made from these materials and exposed to raw 
water, then general corrosion is a significant aging mechanism. These considerations are further examined in Section 4.3.2.

Titanium and its alloys are fully corrosion resistant for all fluid applications [4.11]. The immunity to corrosion of titanium is observed regardless of oxygen content in high purity water applications and contaminants encountered in raw water applications. The excellent corrosion resistance of titanium resuits from the formation of very stable, continuous, highly adherent, and protective oxide film on metal surfaces. Because titanium is highly reactive and has an extremely high affinity for oxygen, these surface oxide films form spontaneously and instantly when fresh metal is exposed to air and/or moisture [4.11]. Therefore, if the heat exchanger components are made from titanium or its alloys, then general corrosion is not a significant aging mechanism.

Copper-nickel materials have excellent resistance to general corrosion for all fluid applications [4.11] except raw water. Nickel addition exceeding $3.5 \%$ generally prevents dealloying. Only at temperatures above $100^{\circ} \mathrm{C}\left[212^{\circ} \mathrm{F}\right]$, in low-flow conditions, and in high local heat flux applications has dealloying of copper nickel been observed. These conditions do not exist for heat exchangers in the scope of this AMG. Therefore, if the heat exchanger components are made from copper-nickel and are exposed to raw water, then general corrosion is a significant aging mechanism. These conditions are further examined in Section 4.3.2.

Admiralty brass materials have excellent resistance to general corrosion $[4.11\}$ for all fluid applications. For raw water applications, admiralty brass materials have the best resistance to corrosion of all typically used materials except titanium. A metallurgical dealloying process (i.e., dezincification) is a common general corrosion mechanism for brass material. This process involves zinc moving out of solution and leaving the weaker and more porous layer of copper and copper oxide. Materials containing more than $15 \%$ zinc are susceptible to dezincification. Cast materials usually contain much lower levels of zinc, but some wrought materials, particularly brasses, may have zinc levels exceeding $15 \%$. Tin tends to inhibit dealloying. Small amounts of phosphorus, arsenic, or antimony added 10 admiralty metal inhibits dezincification. In the fluid environments under consideration, dealloying and the resultant general corrosion occurs at a slow rate [4.11]. Therefore, if the heat exchanger components are made from inhibited admiralty brass with greater than $15 \%$ zinc content, then general corrosion is a significant aging mechanism. These considerations are further examined in Section 4.3.2.

The external ambient environment of the heat exchanger is mildly corrosive. With the exception of carbon steel, exterior surfaces exposed to the environment have excellent resistance to general corrosion. The external carbon steel surfaces are usually coated or painted which effectively mitigates general corrosion. Therefore, if the heat exchanger shell, waterbox, and support assembly exposed to the external environment is made from carbon and low alloy steel and protective coatings are applied to the external surfaces, then general corrosion is not a significant aging mechanism. Adequate maintenance of the protective coatings is a qualifying condition for carbon and low alloy steels heat exchanger shells. Section 5.3.3 describes an effective coatings program.

Leakage from heat exchanger flanges and adjacent piping can expose the external surfaces to a corrosive environment. Fluid leakage from the flanges can result in corrosion of the exposed surfaces. The PWR CVC heat exchangers (regenerative, letdown, excess letdown, and seal water) 
are particularly susceptible. General corrosion is a significant aging mechanism for heat exchanger external surfaces and pressure boundary fasteners that could be exposed to borated fluid leakage. These considerations are further examined in Section 4.3.2.

Lubricating oils in their pure form are non-aggressive and non-corrosive environments for metal components used in all heal exchangers. However, contaminants (water, oxygen, chemicals, and particulate) (an create a corrosive environment for carbon and low alloy steels. The titanium, stainless and high alloy steels, copper nickel, and brass materials, are resistant to general corrosion 14.111. Therefore, if the heat exchangers components are made from carbon or low alloy steel materials, and purity of the lubricating oil is not adequately maintained, then general corrosion of the exposed components is a significant aging mechanism. These considerations are further examined in Section 4.3.2.

\subsection{Pitting}

Deterioration by pitting is one of the most common types of localized corrosion encountered in aqueous environments. Once pits are initiated, they may continue to grow by a self-sustaining process; that is, the corrosion process within a pit produces conditions that aro stimulating and necessary for continuing corrosion of the pit 14.111 .

Chloride is the most common agent for initiation of pitting in stainless steel materials. The resistance to pitting initiation in stainless steel is influenced by chromium and molybdenum content. It is not possible, however, to establish a single critical chloride limit for each grade of stainless steel below which pitting will not occur. Therefore, if the heat exchanger components are made from stainless or high alloy steel, and exposed to chlorinated raw water, then pitting corrosion is a significant aging mechanism. These considerations are further examined in Section 4.3.2.

Because of its protective oxide film, titanium exhibits anodic pitting potentials that are very high $(>1 \mathrm{~V})$; therefore, pitting corrosion is not a concern for titanium or its alloys. As a result, if the heat exchanger components are made from titanium or its alloys, then pitting corrosion is not a significant aging mechanism. Copper alloys do not corrode primarily by pitting but, because of metallurgical and environmental factors the corroded surface does show a tendency toward nonuniformity [4.11]. In raw water applications, pitting tends to occur more often under conditions of relatively low water velocity, typically less than two to three feet/second. Of the copper alloys, the most pit resistant are the aluminum bronzes with less than $8 \%$ aluminum and the low-zinc brasses (i.e., admiralty). Copper-nickel alloy tends to have intermediate pitting resistance. Therefore, if the heat exchanger components are made from these copper alloys and are exposed to raw water service applications, then pitting corrosion is a significant aging mechanism. These considerations are further examined in Section 4.3.2.

Pitting of carbon and low alloy steel materials in raw water applications has been noted in the industry to be a significant aging mechanism. Therefore, if the heat exchanger components are made from carbon and low alloy steel and are exposed to raw water service applications, then pitting corrosion is a significant aging mechanism. These conditions are further examined in Section 4.3.2. 


\subsection{Galvanic Corrosion}

Galvanic corrosion occurs when dissimilar materials with significantly different electrical potentials (Table 4-2) are connected through a conducting fluid (or clectrolyte). A review of Table 4-2 and the metallic materials typically used for heal exchanger components (Table 3-3), identified three metals groupings with significantly different electrical potentials.

Anodic

Aluminum

Iron and Carbon Steel

$4 \%$ to $6 \%$ Chromium Steel
Mid-Range

Nickel

Brasses

Bronzes
Cathodic

Ferritic Stainless (passive)

Austenitic Stainless (passive)

Titanium

The "active" ferritic and austenitic stainless materials near the anodic end of the galvanic series (Table 4-2) have not been included in these groupings. Active stainless material occurs in very low oxygen environments (1 $102 \mathrm{ppb}$ ). The protective chromium oxide surface layer cannot be sustained or metallurgical flaws (primarily heat treating or welding) result in localized areas where insulficient chromium is available to react with oxygen to form the protective layer. The heat exchanger applications in the scope of this $A M G$ are exposed to fluids with oxygen levels of $20 \mathrm{ppb}$ or greater. Heat exchanger manufacturing quality control programs for nuclear service require inspections to detect and repair metallurgical flaws that would result in active stainless steel surfaces.

When the dissimilar material surfaces in the metal grouping listed above are connected by an electrolyte, galvanic corrosion occurs. Solid particles move from the surface of the material which is eloser to the anodic end of the galvanic series chart through the electrolyte and to the surface of materials which are further from the anodic end. The more anodic material corrodes and the more cathodic material is essentially unatiected.

Therefore, if the heat exchanger wetted parts are made from stainless and high alloy steel or titanium, then galvanic corrosion is not a significant aging mechanism. Components made from materials in the mid range and anodic metal groupings are further examined below for lubricating oil applications, closed cooling water applications, and the affects of external environment. Further examination is contained in Section 4.3.2.

Lubricatting oils, even in the contaminated condition, are not good conducting electrolytes. Therefore, if the heat exchanger wetted parts are exposed to lubricating oils, then galvanic corrosion is not a significant aging mechanism. This determination applies to materials in the three metal groupings.

Fluid in closed cooling water applications provides an aqueous environment which can lead to galvanic corrosion of the materiats in the anodic and mid range metal groupings. However, the corrosion inhibitors used in these applications reduce the conductive properties of the lluid (electrolyte). Therefore, if the heal exchanger wetted parts are exposed to closed cooling watce treated with an appropriate inhibitor, then galvanic corrosion is not a significant aging mechanism. Monitoring the water chemistry and maintaining operationat chemistry during plant outages while the heat exchanger remains filled are qualifying conditions. 
The ambient environment is not a good conducting electrolyte to support galvanic corrosion. Therefore, if the external surfaces of the heat exchanger are exposed to the ambient environment, then galvanic corrosion is not a significant aging mechanism. This determination applies to materials in the three metal groupings.

\subsection{Microbiologically Influenced Corrosion}

MIC occurs in fluid streams which can sustain microbiological growth and where the fluid velocities are low or there is intermittent flow conditions [4.3]. MIC can result in corrosion over large surface areas but more likely occurs in local areas where microorganisms attach themselves to metal surfaces. There are no known metals which are completely immune to MIC. MIC is generally most prevalent in raw water systems. Microorganisms are transported from raw water systems to treated water systems, because they are the source of make-up supply to systems that process water for treated water systems. Microorganism growth can also be generated in treated water systems that are open to the atmosphere (vented storage tanks and open pools). MIC is effectively mitigated in fluid systems which operate at temperatures above $\left.100^{\circ} \mathrm{C} 1212^{\circ} \mathrm{F}\right]$. Microbes cannot survive at elevated temperatures.

Bulk fluid velocities within these heat exchangers are high during periods of operation; however, all heat exchanger geometries contain areas such as crevices, flow diversion devices, etc. where fluid velocity is very low or non-existent during operation. It is in these low flow areas where microorganisms concentrate and aggressively attack the surface. In multi-heat exchanger system applications, the heat exchangers may be isolated and filled with fluid for long periods of time. This condition further promotes the occurrence of MIC.

Several special cases of elevated temperature, lubricating oil, and closed cooling water applications are examined below. The affects of external environment are also examined. The remaining heat exchanger applications are further examined in Section 4.3.2.

The fluid in the BWR RWCU regenerative and non-regenerative heat exchangers and PWR CVC regenerative, letdown, excess letdown and seal water heat exchangers is reactor coolant at temperatures above $100^{\circ} \mathrm{C}\left[212^{\circ} \mathrm{F}\right]$ during plant operation. These elevated fluid temperatures in the system eliminate the potential for $\mathrm{MIC}$ in the heat exchangers. Therefore, MIC is not a significant aging mechanism for the RWCU and CVC system heat exchanger components.

Fluid in the RHR heat exchangers is treated water during normal operation and periodic testing. The heat exchangers are isolated and filled during normal operation. Therefore, water in the heat exchangers is stagnant for long periods of time. When the plant is shut down, the RHR heat exchangers are used for reactor coolant decay heal removal. The heal exchangers do not operate at elevated temperatures for very long. With treated water and periodic operation at elevated temperature, the RHR heat exchangers are not very susceptible to MIC. However, the RHR heat exchanger components are further exanined in Section 4.3.2.

Lubricating oils, even in the contaminated condition, do not support microorganism growth. Therefore, if the heat exchanger components are exposed to lubricating oils, then MIC is not a significant aging mechanism. 
Microorganisms can enter closed cooling systems from two sources; storage tanks vented to the atmosphere and the biological material in the treated water make-up. However, the controlled levels of biocides normally added to these systems create a hostile enviromment for microorganisms. Therefore, if the heat exchanger components are exposed to closed cooling water treated with biocides, then MIC is not a significant aging mechanism. Periodically placing the heat exchangers into service and maintaining operational chemistry during plant outages is a qualifying condition.

The ambient enviromment does not support microbiological growth on the external surfaces of heat exchangers. Therefore, if the external surfaces are exposed to the ambient environment, then MIC is not a significant aging mechanism.

\subsubsection{Stress Corrosion Cracking}

A variety of metals ranging from titanium and stainless steel to copper alloys and carbon steel are utilized (Table 3-3) for the heat exchangers evaluated in this AMG. They are exposed to several different environments (Section 3.4). IASCC is evaluated in Section 4.3.1.2. The two) remaining forms of SCC (intergranular and transgranular) are evaluated in the following subsection. Due to the unique nature of the various process fluid environments, specific considerations related to IGSCC significance determinations are discussed in Section 4.3.2.

SCC of stainless steel material in primary coolant water operating temperatures of 260 to $315^{\circ} \mathrm{C} 1500^{\circ}$ to $6000^{\circ} \mathrm{F}$ has heen studed extensively 14.21$]$. However, many heat exchanger applications evaluated in this AMG do not operate at these high temperatures. Although SCC is primarily an aging mechanism associated with stainless and high alloy stecls, other materials such as wrought brass/bronze are not immune to this aging mechanism under certain conditions.

The lubricating oil and closed cooling water applications, and external ambient environments do not support the stress corrosion cracking aging mechanisms. The operating temperatures are below $54^{\circ} \mathrm{C}\left|130^{\circ} \mathrm{F}\right|$. There have not been any incidents in the industry of stress corrosion cracking in these applications and environments (see Section 3). Therefore, if the heal exchanger components are in lubricating oil or closed cooling water applications, and the components are exposed to ambient environments, then stress corrosion cracking is not a significant aging mechanism. However, as discussed helow, admiralty brass materials maty be used in some closed cooling water heat exchanger applications.

\subsection{Intergranular Stress Corrosion Cracking}

Stainless steel may he susceptible to IGSCC for the conditions summarized on Figure 4-2 (see Section 4.1.5.1 above). At temperatures below $177^{\circ} \mathrm{C} 1350^{\circ} \mathrm{Fl}$, stainless stecls are susceptible to IGSCC in water with dissolved oxygen levels above 1 ppm. At temperatures below $54^{\circ} \mathrm{C} 11.30^{\circ} \mathrm{F}$, stainless steels are not susceptible to IGSCC 14.22]. Fluid in the BWR RWCU non-regenerative heat exchangers is cooled below $177^{\circ} \mathrm{C} 13.50^{\prime \prime} \mathrm{F} \mid$ by regenerative heal exchangers located upstream. The dissolved oxygen levels of water entering the non-regenerative heat exchangers are below $0.2 \mathrm{ppm}$. Therefore, if regenerative heat exchangers are located 
upstream from the non-regenerative heat exchangers, then IGSCC is not a significant aging mechanism for the stainless steel components of the RWCU non-regenerative heat exchangers.

Fluid in the PWR CVC system heat exchangers (regenerative, letdown, excessive letdown, and seal water) and BWR RWCU system regenerative heat exchangers is reactor coolant which is greater than $177^{\circ} \mathrm{C} 1350^{\circ} \mathrm{F}$. Stainless and high alloy steel may be susceptible to IGSCC at temperatures above $\left.177^{\circ} \mathrm{C} 1350^{\circ} \mathrm{F}\right]$. Therefore, if these heat exchanger components are made of stainless and high alloy steel and exposed to reactor coolant, then IGSCC is a significant aging mechanism. These considerations are further examined in Section 4.3.2.

The most important variable affecting the susceptibility of titanium to stress corrosion cracking (IGSCC and TGSCC) in all fluid applications is the alloy composition of the material. Unalloyed titanium is generally regarded as immune to stress corrosion cracking unless the material has an oxygen content of $0.3 \%$ or greater. Titanium alloys containing greater than $6 \%$ aluminum are susceptible to stress corrosion cracking. Alloying elements of tin, manganese, and cobalt will increase susceptibility (over unalloyed titanium) to stress corrosion cracking, whereas, zirconium addition has no affect and molybdenum, vanadium, and niobium are generally considered beneficial (i.e., decrease susceptibility to stress corrosion cracking) 14.1/1/. Therefore, if heat exchanger components are made from unalloyed titanium or titanium alloyed with zirconium, molybdenum, vanadium, and/or niobium, then stress corrosion cracking is not a significant aging mechanism.

Experimental work has been performed on high toughness carbon steels with water at

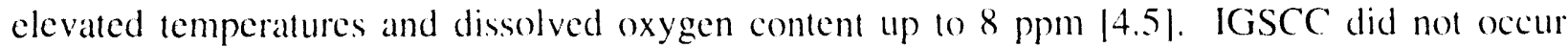
under these conditions. Dissolved oxygen levels of 8 to $12 \mathrm{ppm}$ are common for raw water applications. However, raw water applications are all low temperature. In treated water applications, the water has a dissolved oxygen content of $1102 \mathrm{ppm}$. There have not been any incidents in the industry of IGSCC occurring in heat exchanger components made from carbon and low alloy steels. Therefore, if the heat exchanger components are made from these materials, then IGSCC is not a significant aging mechanism, without additional conditions.

IGSCC has been reported for brass materials when zinc levels exceed $15 \% \quad 14.111$. Admiralty brass materials used for heat exchanger tubes could have zine levels als high as $1.5 \%$. These types of materials would be susceptible to IGSCC. Therefore. if the heal exchanger components are admiralty brass materials with zine content greater than $15 \%$, then IGSCC is a significant aging mechanism. Heat exchanger components made from this type of brass material are further examined in Section 4.3.2.

Copper-nickel alloy is highly resistant to stress corrosion cracking (IGSCC and TGSCC) in all nuclear plant fuid applications 14.231. Therefore, if the heat exchanger components are made from a copper-nickel alloy, then stress corrosion cracking is not a significant aging mechanism, without condition.

iGSCC has been reported for stainless and high alloy steel components exposed to borated water service applications. Therefore, if the heat exchanger components are stainless or high alloy steel and exposed to borated fluids, then IGSCC is a significant aging mechanism. Heat 
exchanger components made from stainless or high alloy steel materials are further examined in Section 4.3.2.

Raw water contains chlorides which cause stress corrosion cracking in stainless steel regardless of temperature. Brackish water or seawater always contains large quantities of chlorides, and fresh water contains chlorides. Several cases of IGSCC in stainless steels have been documented [4.11]. Therefore, if the heat exchanger components are made of stainless and high alloy steel and exposed to raw water, then IGSCC is a significant aging mechanism. These considerations are further examined in Section 4.3.2.

\subsection{Transgranular Stress Corrosion Cracking}

The temperature, tensile stress, and dissolved oxygen levels established in experimental work for susceptibility materials to IGSCC also apply to TGSCC [4.5]. However, higher levels of nitrogen concentration $(0.14 \%$ to $0.19 \%)$ and stress are necessary to produce TGSCC [4.5]. The stainless steel material's specifications used in the industry specify nitrogen concentration ranges of $0.06 \%$ to $0.12 \%$ which are much lower than is required for susceptibility to TGSCC. Therefore, if nitrogen levels of the stainless and high alloy steel heat exchanger components are controlled to less than $0.12 \%$, in the material's specifications, then TGSCC is not a significant aging mechanism.

Experimental work performed on carbon steels [4.5] shows that TGSCC in aqueous solutions at elevated temperatures and moderate dissolved oxygen content $(10 \mathrm{ppm})$ can only occur at unrealistically high stress and nitrogen concentrations. There has not been any incident in the industry of TGSCC for heat exchanger components made from carbon and low alloy steels. Therefore, if the heat exchanger components are made from these materials, then TGSCC is not a significant aging mechanism, without additional condition.

If heat exchanger components are made from unalloyed titanium or; titanium alloyed with zirconium, molybdenum, vanadium, and/or niobium, or; copper-nickel alloy materials, then TGSCC is not a significant aging mechanism, without condition (see discussion in Section 4.3.1.6.1 above).

The determinations for IGSCC of brass materials in Section 4.3.1.6.1 also apply to the susceptibility of these materials to TGSCC. Therefore, if the heat exchanger components are admiralty brass materials with zinc content greater than $15 \%$, then TGSCC is a significant aging mechanism. Heat exchanger components made from this type of brass material are examined in Section 4.3.2.

\subsubsection{Erosion and Erosion/Corrosion}

Erosion and erosion/corrosion requires fluid velocities in the moderate to high range. Erosion occurs when the liquids contain particulate matter, gases contain liquid droplets or particulate, or there is significant levels of fluid turbulence or cavitation. Erosion/corrosion occurs when the base material is susceptible to general corrosion in fluid environments. 
Components made from stainless and high alloy steels are resistant to corrosion and have a high surface hardness. They are considered much less susceptible to erosion and erosion/corrosion than other materials. However, severe fluid turbulence or cavitation have resulted in erosion of high alloy materials. Therefore, if the heat exchanger components are made from stainless or high alloy steel and subject to severe turbulence or cavitation in primary water applications, then erosion and erosion/corrosion are significant aging mechanisms. These conditions are further examined in Section 4.3.2.

For titanium and titanium alloys, the critical fluid velocity in seawater where erosion and erosion/corrosion has been observed to occur, is $27 \mathrm{~m} / \mathrm{s} / 90 \mathrm{ft} / \mathrm{s}$ ] [4.24]. Numerous tests have shown that titanium has outstanding resistance to erosion and erosion/corrosion even in situations where the seawater contained fine abrasive sand. Cavitation resistance lests have also proved titanium to be one of the metals most resistant to erosion degradation from caviation 14.24]. Therefore, if the heat exchanger components are made from titanium or titanium alloys, then erosion and erosion/corrosion are not significant aging mechanisms, without condition.

Admiralty brass and copper-nickel alloys form tightly adhering corrosion product films when exposed to raw water, treated water, and closed cooling water applications. These corrosion product films tend to resist erosion and erosion/corrosion caused by turbulently flowing water carrying entrained air. The critical fluid velocily, assuming no abrasive sand or particles in the fluid stream, where erosion and erosion/corosion has been observed to oceur is as follows [4.23].

- $1.8 \mathrm{~m} / \mathrm{s}|6 \mathrm{ft} / \mathrm{s}|$

- $3 \mathrm{~m} / \mathrm{s}|10 \mathrm{H} / \mathrm{s}|$

- $4.6 \mathrm{~m} / \mathrm{s}|15 \mathrm{tt} / \mathrm{s}|$

Therefore, if the heat exchanger components are made from admiralty brass, and located in treated or closed cooling water applications, and are exposed to fluid velocity greater than $1.8 \mathrm{~m} / \mathrm{s} \mid 6 \mathrm{ft} / \mathrm{s}]$, then erosion and erosion/corrosion are significant aging mechanisms.

If the heat exchanger components are made from copper-nickel $(10 \%)$, and located in treated or closed cooling water applications, and are exposed to fluid velocity greater than $3 \mathrm{~m} / \mathrm{s}$ [10 t//s], then erosion and erosion/corrosion are significant aging mechanisms.

If the heat exchanger components are made from copper-nickel $(30 \%)$, and located in treated or closed cooling water applications, and are exposed to fluid velocity greater than $4.6 \mathrm{~m} / \mathrm{s}[15 \mathrm{ft} / \mathrm{s}]$, then erosion and erosion/corrosion are significant aging mechanisms.

If the heat exchanger components are made from either admiralty brass, copper-nickel $(10 \%)$ or copper-nickel $(30 \%)$, and located in raw water applications where abrasive particles are present, then erosion and erosion/corrosion are significant aging mechanisms. These conditions are further examined in Section 4.3.2. Erosion and erosion/corrosion of carbon stecl heal exchanger components has been widely recognized to be significant aging mechanisms in raw water, treated water, closed cooling water, and primary coolant applications. These conditions are further examined in Section 4.3.2. 
Heat exchanger fasteners and support assemblies are not exposed to fluid flow conditions. Therefore, erosion and erosion/corrosion are not significant aging mechanisms for these components in all heat exchanger applications without condition.

\subsubsection{Wear}

Degradation from wear requires two parts in relative motion that are in contact or the clearance between the moving parts is very small. The heat exchanger tube-to-tube sheet joint and tube-to-partition joint are in motion due to flow induced vibration (i.e., cooling and process fluid) and thermal expansion. Clearances at these interface joints is very small. Therefore, wear of these heat exchanger interface joints is further examined in Section 4.3.2.

All other heat exchanger components do not experience relative motion with close tolerances. Therefore, wear is not a significant aging mechanism for these components in all applications, without conditions.

\subsubsection{Fouling}

Solid particles in the fluid stream and physical configurations that result in very low fluid velocity are required for heat exchanger degradation to occur from fouling. Fouling occurs predominantly in rough filtered raw water applications from particulate transfer and/or biological activity. Fouling also occurs in treated water applications where the heat exchanger supply line originates at the bottom of tanks or reservoirs (significant quantities of corrosion products may accumulate). Treated water applications are also subject to biological activity. Reservoirs in lubricating oil applications may accumulate solid particles from bearing wear which could cause heat exchanger fouling.

Therefore, if the heat exchanger is located in raw water applications, or treated water applications (where the supply originates at the bottom of a tank or reservoir), or in lubricating oil applications, then fouling of the heat exchanger is a significant aging mechanism. These conditions are further examined in Section 4.3.2.

In closed cooling water applications, particulates and biological activities are controlled to low levils by corrosion inhibitors and biocides. Therefore, if the heat exchanger components are subject to closed cooling water applications, then fouling is not a significant aging mechanism.

Primary coolant water is fine filtered to remove particulates, deionized, and is low in oxygen content. Biological activity cannot be sustained in primary coolant water applications. Therefore, all heat exchanger materials in contact with primary coolant water are not susceptible to general corrosion. Particulate levels are very low; therefore, fouling is not a significant aging mechanism. An exception to this conclusion is fouling of the PWR CVCS heat exchangers (regenerative, letdown, seal water, and excess letdown). These heat exchangers are susceptible to precipitation fouling from the primary coolant which is borated. Therefore, fouling is a significant aging mechanism for the CVCS heat exchanger components. These heat exchangers are further examined in Section 4.3.2. 
Heat exchanger pressure boundary fasteners and support assembly are not exposed to the cooling or process fluid. Therefore, fouling is not a significant aging mechanism for these components, without conditions.

\subsubsection{Aging Mechanism Evaluations of Heat Exchanger Components}

This section further examines selected aging mechanisms (i.e., thermal embrittlement, stress relaxation, creep, mechanical fatigue, corrosion, stress corrosion cracking, erosion and erosion/corrosion, wear, and fouling) for heat exchanger components identified in Section 4.3.1.

For ease of evaluating the aging mechanisms, Sections 4.3.2.1 through 4.3.2.5 evaluate the aging mechanisms by heat exchanger component.

Section 4.3.2.1: Tubes/Coils

Section 4.3.2.2: Tube Sheets

Section 4.3.2.3: Shell/Nozzles/Internals (Baffles, Floating Head, Impingement Plate, etc.)

Section 4.3.2.4: Waterbox/Channel Head/Divider Plate

Section 4.3.2.5: Pressure Boundary Fasteners/Support Assembly

For ease of use by plant personnel, the results of the aging management evaluations are summarized in Tables 4-3 through 4-8.

Table 4-3: $\quad$ Primary Water Heat Exchangers

Table 4-4: $\quad$ Treated Water Heat Exchangers

Table 4-5: $\quad$ Closed Cooling Water Heat Exchangers

Table 4-6: Lubricating Oil Heat Exchangers

Table 4-7: $\quad$ Raw Water Heat Exchangers

Table 4-8: Atmospheric Heat Exchangers (Drywell/Reactor Building/Containment)

Tables 3-5 and 3-6 show the tube and shell side fluids and Table 3-3 shows the materials for the various heat exchangers and associated components in the scope of this AMG. For those heat exchangers where the shell side is subject to atmospheric conditions (i.e., Drywell/Reactor Building/Containment) the evaluation is bounded by $49^{\circ} \mathrm{C}\left[120^{\circ} \mathrm{F}\right]$ and $100 \%$ relative humidity. Inerting of the drywell in BWR plants is not considered in the evaluation. Primary water in PWR plants is borated to control reactivity in the core. The characteristics of this borated fluid are considered in the evaluation of aging mechanisms for the PWR plant primary water heat exchangers.

Section 5 discusses programs/techniques to effectively manage those aging mechanisms that are significant for heat exchanger components.

\subsubsection{Tubes/Coils}

The heat exchanger tubes are exposed to both the process and cooling fluid media. From the Section 4.3.1 evaluations some aging mechanisms were determined to be not significant and several aging mechanisms required further evaluation. Figure 4-3 depicts many of the heat exchanger tube aging mechanisms. This section provides further evaluation of those aging 
mechanisms that may cause tube degradation. From Section 4.3.1 the heat exchanger tubes are susceptible to:

- Thermal embrittlement and creep of all tube materials (Table 3-3) in those heat exchangers applications operating continuously at temperatures greater than $93^{\circ} \mathrm{C}$ $\left[200^{\circ} \mathrm{F}\right]$ (Section 4.3.1.1).

- Mechanical fatigue of all tube materials in all heat exchanger applications (Section 4.3.1.4).

- General corrosion of carbon and low alloy steel material exposed to treated water, raw water, and closed cooling water applications; and lubricating oil applications if the purity is not maintained Section 4.3.1.5.1).

- General corrosion of stainless and high alloy steel, copper-nickel alloys, and admiralty brass tube material in raw water applications (Section 4.3.1.5.1).

- General corrosion (dezincification) of admiralty brass tube material with zinc content greater than $15 \%$ (Section 4.3 .1 .5 .1 ).

- Pitting of carbon and low alloy steel, stainless and high alloy steel, admiralty brass, and copper nickel tube materials in raw water applications (Section 4.3.1.5.2).

- Galvanic corrosion of carbon and low alloy steels, admiralty brass, and copper nickel tube materials in primary water, treated water, and raw water applications (Section 4.3.1.5.3).

- MIC of titanium, stainless and high alloy steel, carbon and low alloy steel, admiralty brass, and copper nickel alloy tube material in treated water, raw water, and closed cooling water (without biocide treatment) application (Section 4.3.1.5.4).

- IGSCC of stainless and high alloy steel tubing in primary water applications where the temperature is greater than $177^{\circ} \mathrm{C}\left[350^{\circ} \mathrm{F}\right]$ (Section 4.3.1.6.1).

- IGSCC of admiralty brass tubing with zinc content greater than $15 \%$ in treated water, raw water, and closed cooling water applications (Section 4.3.1.6.1).

- IGSCC of stannless and high alloy steel tube material in raw water and PWR primary water (i.e., borated and at temperatures less than $177^{\circ} \mathrm{C}\left[350^{\circ} \mathrm{F}\right]$ ) applications (Section 4.3.1.6.1).

- TGSCC of admiralty brass tubing with zinc content greater than $15 \%$ in treated water, raw water, and closed cooling water applications (Section 4.3.1.6.2).

- Erosion and erosion/corrosion of admiralty brass and copper nickel tube material in treated water, closed cooling water, and raw water applications and stainless or high alloy steel tube material subject to severe turbulence or cavitation (Section 4.3.1.7). 
- Wear of tubing in all heat exchanger applications (Section 4.3.1.8).

- Fouling of heat exchanger tubes in raw water, treated water (where the supply originates at the bottom of a tank or reservoir), lubricating oil, and PWR plant primary water applications (Section 4.3.1.9).

\subsection{Thermal Embrittlement and Creep}

The BWR plant RWCU system regenerative heat exchanger tubes and the PWR plant CVC system regenerative, letdown, excess letdown, and seal water heat exchanger tubes are ontinuously exposed to reactor coolant temperatures ranging from $288^{\circ}$ to $316^{\circ} \mathrm{C}\left[550^{\circ}\right.$ to $\left.600^{\circ} \mathrm{F}\right]$. Tubes in these heat exchangers, because they are exposed to the reactor coolant, are predominantly stainless steel. In some cases titanium may be used.

From Section 4.2.5.1 and Reference 4.5 thermal embrittlement is a concern for cast (duplex) austenitic stainless steel materials. Stainless steel heat exchanger tubing may be either austenitic or ferritic and is manufactured using a cupping and drawing method [4.15, 4.24]. Stainless steel heat exchanger tubing is not manufactured as a casting. Therefore, thermal embrittlement is not a significant aging mechanism for stainless steel heat exchanger tubing without conditions.

From Reference 4.2 titanium is not susceptible to thermal embrittlement when exposed to temperatures less than $370^{\circ} \mathrm{C}\left[700^{\circ} \mathrm{F}\right]$ for extended periods of time. Reactor coolant temperatures range between $288^{\circ}$ to $316^{\circ} \mathrm{C}$ [ $550^{\circ}$ to $600^{\circ} \mathrm{F}$, therefore, thermal embrittlement is not a significant aging mechanism for titanium heat exchanger tubing without conditions.

Creep of a metal is dependent on temperature, stress level, and length of time exposed to concurrent high temperature and stress. The effects of creep are particularly important if the temperature is greater than the recrystallization temperature of the metal [4.2]. For stainless steel the recrystallization temperature is approximately 49 percent of the material's melting temperature or $538^{\circ} \mathrm{C}\left[1000^{\circ} \mathrm{F}\right]$. Therefore, if the heat exchanger tubes are manufactured from stainless steel, then creep is not a significant aging mechanism without condition.

For titanium, the recrystallization temperature is approximately 30 percent of the material's melting temperature or $316^{\circ} \mathrm{C}\left[600^{\circ} \mathrm{F}\right]$. The yield strength of unalloyed titanium at $316^{\circ} \mathrm{C}\left[600^{\circ} \mathrm{F}\right]$ is 83 to $103 \mathrm{MPa}$ [12 to $15 \mathrm{ksi}$ ] for Grade 1,90 to $124 \mathrm{MPa}$ [13 to $18 \mathrm{ksi}$ ] for Grade 2, $138 \mathrm{MPa}$ [20 ksi] for Grade 3, and $165 \mathrm{MPa}$ [24 ksi] for Grade 4 [4.24]. Heat exchanger tubing designed for a high allowable stress level is not a requirement because loading on the tube exterior (i.e., shell side fluid pressure) is opposed/counteracted by the tube internal fluid pressure. Also, thermal expansion of the tubes is accounted for in the design of heat exchangers. Therefore, the yield strength (and tensile strength) of the heat exchanger tubing is not a significant factor and will remain well below the $316^{\circ} \mathrm{C}\left[600^{\circ} \mathrm{F}\right]$ yield strength values identified above for unalloyed titanium (i.e., PWR reactor coolant pressure is $15.4 \mathrm{MPa}[2235$ psi]). Therefore, if the heat exchanger tubes are manufactured from titanium, then creep is not a significant aging mechanism. 


\subsection{Mechanical Fatigue}

Over $60 \%$ of the NPRDS reported aging failures were associated with heat exchanger tubes (Table 3-15), however, from Section 3.6, fatigue and vibration represent only about 5\% of the total number of heat exchanger failures caused by aging. Figure 4-3 shows that fatigue cracking can occur at the tube-to-partition joint or at the midspan of a tube.

From Section 4.3.1.4 heat exchanger tubes are subject to the most severe mechanical and hydraulic stressors from both the process and cooling fluid streams. These stressors (i.e., cyclic loads) are applied to the heat exchanger tubes when the unit is placed into service and removed from service, when undergoing load changes, and when operating under steady state conditions. Therefore, mechanical fatigue is a significant aging mechanism for heat exchanger tubes in all service applications regardless if the heat exchanger is continuously or intermittently operated.

\subsection{Corrosion}

From Table 3-3, heat exchanger tubes within the scope of this AMG are not manufactured from carbon or low alloy steel.

\section{General Corrosion}

Dezincification is the usual form of corrosion for uninhibited brasses in prolonged contact with waters high in oxygen and carbon dioxide. It is frequently encountered with quiescent or slowly moving solutions. Slightly acidic water, low in salt content and at room temperature, is likely to produce uniform attack, but neutral or alkaline water, high in salt content and above room temperature, often produces plug-type attack [4.11]. The admiralty brass heat exchanger tubes evaluated in this AMG are classified as inhibited brass containing less than 15\% zinc. Therefore, if the heat exchanger tubes are manufactured from inhibited admiralty brass, then general corrosion (dezincification) is not a significant aging mechanism regardless of service environment.

Copper-nickel alloys and inhibited admiralty brasses have general corrosion rates of $25 \mu \mathrm{m} / \mathrm{yr}[1 \mathrm{mil} / \mathrm{yr}]$ or less in unpolluted fresh water applications. Copper-nickel alloys and inhibited admiralty brasses in relatively quiescent seawater applications have general corrosion rates typically less than $50 \mu \mathrm{m} / \mathrm{yr}[2 \mathrm{mil} / \mathrm{yr}]$ and often show general corrosion rates less than $25 \mu \mathrm{m} / \mathrm{yr}$ [ $1 \mathrm{mil} / \mathrm{yr}]$. The superior performance of copper nickel alloys and inhibited admiralty brasses, against general corrosion, is partly the result of their inherent insolubility in raw water, but more because of their ability to form tightly adhering corrosion product films that resist erosion and further corrosion [4.11]. The general corrosion rate of copper-nickel alloys and inhibited admiralty brasses tend to decrease as duration of exposure increases. Cycling service or exposure to ammonia solutions, however, can lead to fracturing of the protective corrosion product film and an increased general corrosion rate. Heat exchanger tube thickness ranges from 890 to $2410 \mu \mathrm{m}$ [from 35 to $95 \mathrm{mil}$ ]. Therefore, if the heat exchanger tubes are copper-nickel alloys or inhibited admiralty brasses, exposed to raw water applications, and operation is cyclic then general corrosion is a significant aging mechanism particularly for those tubes that are relatively thin (i.e., less than $1270 \mu \mathrm{m}|50 \mathrm{mil}|$ ). 
Corrosion of stainless and high alloy steels in raw water applications is affected by the chloride, sulfur and ammonia content of the water. When the raw water application is brackish or seawater and the heat transfer is into the chloride containing fluid, then corrosion of stainless and high alloy steel is most severe. The corrosivity of a particular level of chloride can be strongly affected by other chemical constituents in the raw water. Test specimens of Type 304 stainless steel were exposed to flowing seawater at 0.3 to $0.6 \mathrm{~m} / \mathrm{s}[1$ to $2 \mathrm{ft} / \mathrm{s}]$ for six months [4.24]. General corrosion rates range from 5 to $1.3 \mu \mathrm{m} / \mathrm{yr}[0.2$ to $0.5 \mathrm{mil} / \mathrm{yr}]$, however, local attack (pitting) was observed to be a maximum of $1270 \mu \mathrm{m}[50 \mathrm{mil}]$ in the six month time frame. Therefore, a stainless steel heat exchanger tube exposed to brackish or seawater would tend to fail from local perforation rather than from loss of all wall thickness. Therefore, general corrosion of stainless and high alloy heat exchanger tubing in raw water applications is not a significant aging mechanism. Pitting, however, is evaluated in the next subsection.

\section{Pitting Corrosion}

From Section 3.6 corrosion accounts to approximately $20 \%$ to $25 \%$ of the heat exchanger failures. Localized pitting is a major contributor to the overall incidence of heat exchanger tube failures and may be aggravated by creviced locations, galvanic couples, stagnation or low velocity raw water flow, deposit accumulation, water line attack, etc. Stainless and high alloy steel, inhibited admiralty brass, and copper-nickel alloy heat exchanger tubing are all susceptible to pitting in raw water applications. Brackish and seawater tend to cause more severe pitting of heat exchanger tubes than does freshwater. For inhibited admiralty brass and copper-nickel alloy tubing a threshold flow velocity of 0.6 to $0.9 \mathrm{~m} / \mathrm{s} \mid 2$ to $3 \mathrm{ft} / \mathrm{s} \mid$ or less with seawater tends to promote the incidence of pitting $[4.11,4.23]$. For stainless and high alloy tubing a threshold value of less than or equal to $1.5 \mathrm{~m} / \mathrm{s}$ [5 ft/s] tends to promote pitting in seawater applications.

From the discussion above for general corrosion, test specimens in flowing seawater of type 304 stainless steel showed pitting to be a maximum of $1270 \mu \mathrm{m}[50 \mathrm{mil}]$ in a six month time frame. For inhibited admiralty brass and copper alloys pitting rates on the order of 635 to $890 \mu \mathrm{m} / \mathrm{yr}$ [25 to $35 \mathrm{mil} / \mathrm{yr}$ ] have been observed [4.11]. If stainless or high alloy steel, inhibited admiralty brass, or copper-nickel alloy heat exchanger tubing thickness ranges from 890 to $2410 \mu \mathrm{m}$ [35 to $95 \mathrm{mil}$ ] and are exposed to raw water applications, then pitting corrosion is a significant aging mechanism.

\section{Galvanic Corrosion}

Heat exchanger tubes are attached to the tube sheet by an expansion process (i.e., rolled) and in some cases welded. The tubes are also supported at various points along the length of the tube by baffles/partitions. Tube spacers may also be installed to minimize the potential of chatter (from tube vibration) due to shell side flow. Heat exchanger design specifications require that materials of construction be compatible and that galvanic couples between adjacent materials be minimized. Additionally, in many instances, sacrificial anodes are installed in the heat exchanger or, some other form of cathodic protection is provided to minimize the effects of galvanic corrosion. Therefore, irrespective of service application, if the heat exchanger tubes and all other components connected to the tubes are manufactured from materials that are close together on the galvanic series chart (Table 4-2), then galvanic corrosion is not a significant aging mechanism for the heat exchanger tubes. If the heat exchanger tubes, and the other components connected 
to the tubes are not manufactured from materials that are close together on the galvanic series chart, but sacrificial anodes or cathodic protection is adequately provided, then galvanic corrosion is not a significant aging mechanism for the heat exchanger tubes.

\section{Microbiologically Influenced Corrosion}

From References 4.3 and 4.11 and industry data presented in Section 3.6, MIC is a significant aging mechanism for most heat exchanger tube materials, particularly in raw water applications. In treated water and closed cooling water (not treated with biocides) applications, however, significant quantities of microbiological activity may be present. Through-wall pitting of tubes or attack at the tube-to-tube sheet joint is the most common manifestation of MIC failures in heat exchangers.

MIC's effect on copper and its alloys (admiralty brass and copper-nickel) involve attack of the corrosion film by the metabolic products of the particular organisms. Ammonia, organic acids, and sulfides are the most common MIC waste products whose effects on copper based alloys are well known [4.3]. MIC of stainless steel tubing is characterized by through wall pitting with preferential attack of weldments (i.e., typically tube-to-tube sheet welds). Titanium is the most MIC resistant metal because the extremely stable oxide film is highly protective in a variety of environments that include all local environments established by the micro-organisms. Service data on MIC of titanium, however, are scarce which may be the reason for the apparent resistance of the material. The use of titanium should not be considered the solution to MIC of heat exchanger tubes. Therefore, irrespective of the material, if heat exchanger tubes are exposed to raw water, treated water, or closed cooling water (not chemically treated with inhibitors and biocides) applications, then MIC is a significant aging mechanism.

\subsection{Stress Corrosion Cracking}

Very few incidents of stress corrosion cracking were identified in Section 3.6 as the primary cause of heat exchanger failures. One reason for this is because stress corrosion cracking must propagate over relatively long periods of time for failure to occur and, for heat exchanger components (i.e., tubes), other aging mechanisms (i.e., fouling, erosion/corrosion, corrosion, etc.) and the corresponding failure mode occurs much more rapidly.

From Figure 4-2 if primary water (i.e., non-borated BWR plants) is greater than or equal to approximately $177^{\circ} \mathrm{C}\left[350^{\circ} \mathrm{F}\right]$ and dissolved oxygen is greater than or equal to $100 \mathrm{ppb}$, then conditions are right for IGSCC of stainless steel to occur.

The RWCU regenerative heat exchanger tubes are stainless steel, and operate at reactor coolant temperature of $288^{\circ} \mathrm{C}\left[550^{\circ} \mathrm{F}\right]$. Dissolved oxygen content of BWR primary coolant from the reactor recirculation system to the RWCU regenerative heat exchanger can range between 50 to $300 \mathrm{ppb}$ during power operation. Therefore, IGSCC of the stainless steel BWR plant RWCU regenerative heat exchanger tubes is a significant aging mechanism. Section 5 discusses programs/techniques to effectively manage IGSCC of these heat exchanger tubes.

All stainless steel materials exposed to PWR plant primary water (i.e., borated CVCS and RHR system) applications are susceptible to IGSCC. Alternating wet and dry periods will allow 
concentration of boron on the heat exchanger lubes and further accelerate IGSCC. Therefore, IGSCC is a significant aging mechanism for the PWR plant CVCS regenerative, letdown, excess letdown, and seal water heat exchanger tubes and RHR heat exchanger tubes.

Chlorides and sulfates significantly increase the potential for IGSCC to occur in stainless steel materials [4.14]. Chlorides and sulfates are present in fresh water, and chloride levels are very high in brackish and seawater. Heat exchangers in raw water applications may be exposed to alternate wet and dry periods which will allow concentration of the chloride containing salts on the tubes. Therefore, if the heat exchanger tubes are stainless steel and exposed to raw water, then IGSCC is a significant aging mechanism.

Admiralty brass heat exchanger tubing evaluated in this AMG is classified as inhibited brass containing less than $15 \%$ zinc. A zinc content greater than $15 \%$ is required for IGSCC and/or TGSCC to occur. Therefore, if the heat exchanger tubes are manufactured as inhibited admiralty brass, then IGSCC and TGSCC are not significant aging mechanism irrespective of fluid application.

\subsection{Erosion and Erosion/Corrosion}

From Section 3.6 erosion and erosion/corrosion represent approximately $20 \%$ to $25 \%$ of the total number of heat exchanger failures caused by aging and the tubes are the predominant component that failed due to these aging mechanisms. Figure 4-3 shows that erosion and erosion/corrosion can occur to both the heat exchanger tube inside surfaces and outside surfaces. Erosion and erosion/corrosion of the tube outside surface is usually caused by impingement in steam applications and not in those applications where water or lubricating oil flow is on the shell side of the heat exchanger.

\section{Tube Outside Surface Erosion}

Strict controls are placed on the quality/purity of lubricating oil. The chemical properties of these oils are regularly checked. Impurities and particulate matter, which contribute to erosion and erosion/corrosion, are monitored and corrective actions implemented if oil quality/purity fails to meet acceptance standards. From Tables 3-5 and 3-6 all heat exchangers in the scope of this AMG that contain lubricating oil are operated with the lubricating oil on the shell side. Therefore, if chemical properties of the lubricating oil are regularly checked then erosion and erosion/corrosion of the heat exchanger tube outside surface are not significant aging mechanisms.

Applications where the atmosphere (i.e., drywell, reactor building, or containment) flows over the heat exchanger tube outside surface are susceptible to erosion and erosion/corrosion. Air passed over the tube outside surface is cooled by raw or closed cooling water flowing through the tubes (see Tables 3-5 and 3-6). Water vapor is condensed on the tube outside surfaces during the cooling process. This water vapor may be on the acidic side (i.e., $\mathrm{pH}<7$ ). Also, air flow velocities are generally high and frequently change direction due to baffling. Industry experience shows that erosion and erosion/corrosion will occur to admirality metal tubes under these operating conditions [4.2]. The protective oxide film that is normally formed on the tube outside surface is removed under these operating conditions. Therefore, if the heat 
exchanger tubes are made from admiralty metal, and water vapor that is condensed on the tubes is acidic, and air flow across the tubes frequently changes direction, then erosion and erosion/corrosion are significant aging mechanisms.

If the heat exchanger tubes are made from stainless or high alloy steel, titanium or coppernickel alloys and exposed to air flow conditions as described above, then erosion and erosion/ corrosion are not significant aging mechanisms without condition.

Closed cooling water and primary water applications (see Tables 3-5 and 3-6 are fine filtered to remove particulate and deionized to achieve purity. Dissolved oxygen levels in primary water applications are controlled to minimize abrasive corrosion products. Closed cooling water applications contain corrosion inhibitors to minimize abrasive corrosion products. A review of several different heat exchanger manufacturer specification sheets show that shell side fluid velocity ranges from 0.9 to $2.7 \mathrm{~m} / \mathrm{s}[2.9$ to $9.0 \mathrm{ft} / \mathrm{s}]$. This data also shows that (1) stainless steel tubing is used in applications where higher design shell side fluid velocities exist (i.e., $>1.8 \mathrm{~m} / \mathrm{s}[6 \mathrm{ft} / \mathrm{s}]$ ) and (2) in those applications where admiralty and copper-nickel tubing is used design shell side fluid velocities are less than or equal to $1.8 \mathrm{~m} / \mathrm{s}[6 \mathrm{ft} / \mathrm{s}]$.

From Section 4.3.1.7 threshold fluid velocities are provided to distinguish the significance of erosion and erosion/corrosion for certain tube materials. These threshold values assume that no abrasive particles are present in the fluid which is the case for closed cooling water and primary water applications. Therefore, if the closed cooling water and primary water shell side fluid velocities are operated within specified limits, then erosion and erosion/corrosion of the heat exchanger tube outside surfaces are not significant aging mechanisms irrespective of tube material type.

The on! y' heat exchanger application in the scope of this AMG utilizing treated water on the shell side is the BWR plant RHR heat exchangers (see Table 3-5 and 3-6). Stainless steel tubes are used in all BWR plant RHR heat exchanger applications. Shell side fluid is supplied predominantly from the suppression pool which may contain abrasive corrosion products. This system is primarily operated (i.e., monthly or quarterly) to support plant Technical Specification surveillance testing. The total operating time to complete a surveillance test typically ranges from two to eight hours. The total accumulated operating time that RHR heat exchangers are exposed to treated water is, therefore, very low. Also, it is not uncommon to isolate the heat exchangers during these tests. The RHR heat exchangers are also exposed to a mode of operation called decay heat removal. In this mode, primary water flows on the shell side over the heat exchanger tubes. From the discussion above, primary water does not contain abrasive corrosion products, therefore, the contribution to erosion and erosion/corrosion of the tube outside service in this mode of operation is negligible. Therefore, if the BWR plant RHR heat exchangers are operated with treated water on the shell side intermittently (i.e., for testing purposes) and flow rate is maintained within specified limits, then erosion and erosion/corrosion are not significant aging mechanisms. 


\section{Tube Inside Surface Erosion}

Erosion and erosion/corrosion of heat exchanger tube inside surfaces is usually caused by particle impingement or high fluid velocity due to tube pluggage (i.e., installed plugs or fouling) or uncontrolled flow of cooling water.

Closed cooling water and primary water applications (see Table 3-5 and 3-6) are fine filtered to remove particulate and deionized to achieve purity. Dissolved oxygen levels in primary water applications are controlled to minimize accumulation of abrasive corrosion products and maintain the protective oxide layering. In closed cooling water applications, corrosion inhibitors are maintained in solution to minimize accumulation of corrosion products. Therefore, tube fouling is not likely to occur in these applications. A review of several different heat exchanger manufacturer specification sheets show that tube side fluid velocity ranges from 0.6 to $2.1 \mathrm{~m} / \mathrm{s}$ [1.9 to $6.9 \mathrm{ft} / \mathrm{s}$ ]. From Section 4.3.1.7 threshold fluid velocities are provided to distinguish the significance of erosion and crosion/corrosion for certain tube materials. These threshold values assume that no abrasive particles are present in the fluid which is the case for closed cooling water and primary water applications. Therefore, if the closed cooling water and primary water tube side velocities are maintained within specified limit and the change in tube side velocity is calculated whenever tubes are plugged, then erosion and erosion/corrosion of the heat exchanger tube side surfaces are not significant aging mechanisms irrespective of the tube material type.

Raw water applications contain fine particles such as sand and silt that passes through the rough screens and into the heat exchanger tubes. These particles are highly abrasive and raw water is considered to be a corrosive fluid. Therefore, if the heat exchanger tube inside surface is exposed to raw water and the tubes are made from admiralty brass or copper-nickel alloys, then erosion and ercsion/corrosion are significant aging mechanisms. Section 5 discusses programs/techniques to effectively manage erosion and erosion/corrosion of these heat exchanger tubes.

Treated water applications contain fine corrosion products that will collect at the bottom of tanks and reservoirs. These particles are highly abrasive and can be pumped into the heat exchanger tubes if pump suction lines originate at the bottom of the tank/reservoir. Treated water is considered to be a corrosive fluid due to high dissolved oxygen content and particulates. Therefore, if the heat exchanger tube inside surface is exposed to treated water and the tubes are made from admiralty brass or copper-nickel alloys, then erosion and erosion/corrosion are significant aging mechanisms.

\subsection{Wear}

Mechanical tube support wear occurs when tubes vibrate within support or baffle plate holes. Typically, tube support structures made of either carbon steel or stainless steel are more wear resistant than the tube alloys, thus resulting in lube wear. Wear rates increase with the increasing tube-to-tube support plate clearance caused by higher-amplitude vibrations. With increased vibrations, it is also possible to have fatigue cracks at tube-to-tube support plate intersections (see Section 4.3.2.1.2). 
Another damage mechanism resulting from tube vibration is tube-to-tube wear. When the vibrational amplitude is sufficiently high, adjacent tubes can collide with each other causing tubeto-tube fretting wear. Such damage can progress rapidly to cause tube leaks unless the tube vibration is reduced or minimized. Once the tubes have been worn thin, the likelihood of sustaining midspan fatigue cracks is greatly increased. The resultant fatigue cracks are circumferential and OD-initiated.

\subsection{Fouling}

From Section 3.6, fouling is the most predominant aging mechanism to adversely affect heat exchanger performance. NPRDS data shows that fouling accounts for $31 \%$ of the total number of heat exchanger failures while the LER data shows fouling as the primary cause in $44 \%$ of the heat exchangers failures.

Cases of biological and particulate fouling have been noted in raw water heat exchanger applications. Silt, sand, seaweed, clams, etc., can settle and collect in the tubes and/or on the tube sheet surface and block flow. If the heat exchangers are in raw water applications and are alternately wetted and dried for any reason, then salts can precipitate onto the tube surfaces and cause decreased heat exchanger thermal performance.

Particulate material can accumulate in tanks/reservoirs of treated water and lubricating oil systems. This particulate material can be swept into the heat exchanger, settle out, and cause fouling.

PWR plant primary water is borated to control reactivity. This borated fluid flows through the tube side of the CVCS heat exchanges (regenerative, letdown, excess letdown, and seal water) and RHR heat exchangers. This fluid also flows through the shell side of the regenerative heat exchanger. If these heat exchangers are alternatively wetted and dried, then precipitate fouling will occur.

Therefore, if the heat exchanger tubes are uxposed to raw water, subject to PWR plant primary water, or located in treated water or lubricating oil applications where the fluid supply originates at the bottom of a tank or reservoir, then fouling is a significant aging mechanism.

\subsubsection{Tube Sheets}

Heat exchanger tube sheets are exposed to both process and cooling fluid media. From the Section 4.3.1 evaluations, some aging mechanisms were determined to be not significant and several aging mechanisms required further evaluation. This section provides further evaluation of those aging mechanisms that may cause tube sheet degradation. From Section 4.3.1 the heat exchanger tube sheets are susceptible to:

- Thermal embrittlement and creep of all tube sheet materials (Table 3-3) in those heat exchanger applications operating continuously at temperatures greater than $93^{\circ} \mathrm{C}$ $1200^{\circ} \mathrm{Fl}$ (Section 4.3.1.1). 
- Mechanical fatigue of all tube sheet materials in all heat exchanger applications (Section 4.3.1.4).

- General corrosion of carbon and low alloy tube sheet material exposed to treated water, raw water, and closed cooling water applications; and lubricating oil applications if the purity is not maintained (Section 4.3.1.5.1).

- General corrosion (dezincification) of copper alloy tube sheet material where zinc content of the material is greater than $15 \%$ (Section 4.3.1.5.1).

- Pitting of carbon and low alloy steel, stainless and high alloy steel, and copper alloy tube sheet material in raw water applications (Section 4.3.1.5.2).

- Galvanic corrosion of carbon and low alloy and copper alloy tube sheet material in primary water, treated water, and raw water applications (Section 4.3.1.5.3).

- MIC of stainless and high alloy steel, carbon and low alloy steel and copper alloy tube sheet materials in treated water and raw water applications and in closed cooling water applications not treated with biocides (Section 4.3.1.5.4).

- IGSCC of stainless and high alloy tube sheet material in primary water applications where the temperature is greater than $177^{\circ} \mathrm{C}\left[350^{\circ} \mathrm{F}\right]$, in raw water applications, and PWR plant primary water applications that operate at less than $177^{\circ} \mathrm{C}\left[350^{\circ} \mathrm{F}\right]$ (i.e., borated fluid) (Section 4.3.1.6.1).

- IGSCC (Section 4.3.1.6.1) and TGSCC (Section 4.3.1.6.2) of copper alloy tube sheet material containing greater than $15 \%$ zinc in treated water, raw water, and closed cooling water applications.

- Erosion and erosion/corrosion of carbon and low alloy steel and copper alloy tube sheet material in treated water, closed cooling water and raw water applications; and stainless and high alloy tube sheet material subject to severe turbulence or cavitation (Section 4.3.1.7).

- Wear of tube sheets in all heat exchanger applications (Section 4.3.1.8).

- Fouling of tube sheets in raw water applications, treated water and lubricating oil applications only where the supply originates at the bottom of a tank or reservoir, and in PWR plant primary water applications (Section 4.3.1.9).

\subsection{Thermal Embrittlement and Creep}

The BWR plant RWCU regenerative heat exchanger tube sheets and the PWR plant CVCS regenerative, letdown, excess letdown and seal water heat exchanger tube sheets are continuously exposed to reactor coolant temperatures ranging from $288^{\circ}$ to $316^{\circ} \mathrm{C} 1550^{\circ}$ to $600^{\circ} \mathrm{FJ}$. Tube sheets in these heat exchangers are stainless steel because they are located in the reactor coolant fluid stream. 
From Section 4.2.5.1 and Reference 4.5 thermal embrittlement is a concern for cast (duplex) austenitic stainless steel materials. Stainless steel heat exchanger tube sheets are either manufactured as a forging or are made from rolled plate but they are not manufactured as a casting. Therefore, thermal embrittlement is not a significant aging mechanism for stainless steel heat exchanger tube sheets without conditions.

Creep of a metal is dependent on temperature, stress level, and length of time exposed to concurrent high temperature and stress. The effects of creep are particularly important if the temperature is greater than the recrystallization temperature of the metal [4.2]. For stainless steel the recrystallization temperature is approximately 49 percent of the material's melting temperature or $538^{\circ} \mathrm{C}\left[1000^{\circ} \mathrm{F}\right]$. Therefore, if the heat exchanger tube sheet is manufactured from stainless steel, then creep is not a significant aging mechanism without condition.

\subsection{Mechanical Fatigue}

Over $8 \%$ of the NPRDS reported aging failures were associated with heat exchanger tube sheets (Table 3-15), but from Section 3.6, fatigue and vibration represent only about 5\% of the total number of heat exchanger failures caused by aging.

From Section 4.3.1.4 heat exchanger tube sheets are subject to the most severe mechanical and hydraulic stressors from both the process and cooling fluid streams. These stressors (i.e., cyclic loads) are applied to the heat exchanger tube sheets when the unit is placed into service and removed from service, when undergoing load changes, and when operating under steady state conditions. The tube sheet also contains residual stress from manufacturing and installation. Tube sheet holes are drilled and beveled to accommodate the heat exchanger tubes. Residual stresses in the tube sheet exist from this manufacturing process. During installation the tubes are expanded in the tube sheet holes and welded. This installation process may cause residual stress to exist in the tube sheet ligaments (i.e., the material between the holes). The entire tube sheet is welded to the heat exchanger shell. This welding process can cause residual stresses to exist in the tube sheets. Tube plugging maintenance activity is usually accomplished at the tube sheet and may cause additional stresses on the tube sheet. In most instances, fatigue cracking shows up in the tube sheet ligaments.

Therefore, mechanical fatigue is a significant aging mechanism for heat exchanger tube sheets in all service applications regardless of materials and operating characteristics (i.e., continuously or intermittently operated).

\subsection{Corrosion}

From Table 3-3 heat exchanger tube sheets within the scope of this AMG are manufactured from either carbon and low alloy steel, stainless steel, or muntz metal (i.e., a $60 \%$ copper $/ 40 \%$ zinc alloy).

\section{General Corrosion}

Dezincification (sometimes referred to as selective leaching or de-alloying) is the usual form of general corrosion for copper alloy materials in prolonged contact with water high in 
oxygen, carbon dioxide, and chloride. It is frequently encountered with quiescent or slowly moving solutions. Slightly acidic water, low in salt content and at room temperature, is likely to produce layer-type attack, but neutral or alkaline water, high in salt content and above room temperature, often produces plug-type attack [4.2]. Plug-type dezincification is less spread out on the surface than layer-type and can cause pitlike wall perforation more rapidly than layer-type.

The muntz metal heat exchanger tube sheets evaluated in this AMG contain approximately $40 \%$ zinc. Copper alloys with zinc content less than $15 \%$ resist dezincification, however, muntz metal is a two phase structure and usually dezincifies in two stages. Dezincification of muntz. metal can sometimes be detected visually by the reddish appearance of the deposited copper.

Therefore, if the heat exchanger tube sheet is made of muntz metal and exposed to either treated water, closed cooling water or raw water applications, then general corrosion, by dezincification, is a significant aging mechanism. Tables 3-5 and 3-6 identify the various tube and shell side fluids that are exposed to the heat exchanger tube sheets.

Corrosion of stainless steel in raw water applications is affected by the chloride content of the water. When the raw water application is brackish or seawater and if heat transfer is into this fluid, then corrosion of stainless steel is most severe. The corrosivity of a particular level of chloride solution can be strongly affected by other chemical constituents in the fluid. Test specimens of Type 304 stainless steel were exposed to flowing seawater $(0.3$ to $0.6 \mathrm{~m} / \mathrm{s} / 1$ to 2 $\mathrm{ft} / \mathrm{s}]$ ) for six months [4.24]. General corrosion rates range from 5.1 to $12.7 \mu \mathrm{m} / \mathrm{yr}[0.2$ to 0.5 $\mathrm{mil} / \mathrm{yr}$ ], however, local attack (i.e., pitting) was observed to be a maximum of $1270 \mu \mathrm{m}[50 \mathrm{mil}]$ in this six month time frame. Therefore, a stainless steel heat exchanger tube sheet exposed to brackish or seawater would tend to fail from local perforation rather than from loss of wall thickness. Therefore, if the tube sheet is made from stainless steel and is exposed to raw water applications, then general corrosion is not a significant aging mechanism. Pitting, however, is evaluated in the next subsection of the AMG.

General corrosion of carbon and low alloy steel in aqueous environments is well documented and the rate is dependent upon the fluid oxygen content, temperature, and flow rate. The highest general corrosion rates for carbon steel occur under conditions where the fluid is at ambient temperature, saturated with dissolved oxygen, and located in stagnant or slow moving fluid streams [4.11]. Very little general corrosion of the carbon steel occurs in high temperature water or steam applications because a thin black oxide film (i.c., magnetite) forms and rapidly protects the tube sheet surface from further corrosion. General corrosion of carbon steel in lubricating oil applications is very low because oxygen content is low, oils are not good electrolytes, and purification systems are generally installed and/or corrosion inhibitors are added to maintain the oil free of corrosion products.

In treated water and closed cooling water applications carbon steel tube sheets can experience uniform corrosion rates of 25 to $50 \mu \mathrm{m} / \mathrm{yr}$ [ 1 to $2 \mathrm{mil} / \mathrm{yr}$ ] or greater and localized (i.e., pitting) may be significantly greater. Some raw water applications are quite aggressive with regard to general corrosion and may be $254 \mu \mathrm{m} / \mathrm{yr}[10 \mathrm{mil} / \mathrm{yr}]$ or greater $[4.25,4.26]$. Localized pitting may be much more severe in these raw water applications. Many of the heat exchangers, within the scope of this AMG, that are located in treated water, closed cooling water, and raw water service applications are maintained full of fluid and isolated (i.e., standby 
operation) or may be alternately wet and dry. The dry periods will allow concentration of salts and other corrosive constituents to deposit on the tube sheet surfaces. Therefore, if the heat exchanger tube sheet is made of carbon and low alloy steel and exposed to either treated water, closed cooling water, or raw water, then general sorrosion is a significant aging mechanism. Tables 3-5 and 3-6 identify the various tube and shell side fluids that are exposed to the heat exchanger tube sheets.

\section{Pitting Corrosion}

From Section 3.6 corrosion accounts for approximately $20 \%$ to $25 \%$ of the heat exchanger failures. Localized pitting is a major contributor to heat exchanger tube sheet degradation. Pitting is aggravated by creviced locations (i.e., tube-to-tube sheet joint) galvanic couples between materials, stagnation or low velocity fluid flow, deposit accumulation, etc. From the discussion above for general corrosion stainless and high alloy steel, muntz metal, and carbon and low alloy steel heat exchanger tube sheets are all susceptible to pitting in raw water applications. Brackish and seawater tend to cause more severe pitting than does fresh water. For muntz metal tube sheets or threshold flow velocity of 0.6 to $0.9 \mathrm{~m} / \mathrm{s}$ [ 2 to $3 \mathrm{ft} / \mathrm{s}$ ] or less in seawater tends to promote the incidence of pitting [4.11,4.23]. For stainless and high alloy steel tube sheets a threshold value of less than or equal to $1.5 \mathrm{~m} / \mathrm{s}[5 \mathrm{ft} / \mathrm{s}]$ tends to promote pitting in seawater applications. For carbon and low alloy steels no lower threshold flow velocity could be identified above which pitting is not a concern.

From the discussion above for general corrosion, test specimen. of type 304 stainless steel in flowing seawater showed pitting depths to be maximum of $1270 \mu \mathrm{m}$ [50 mil] in a six month time frame [4.11]. Test specimens of carbon steel in flowing fresh water showed pitting depths to range between 178 to $254 \mu \mathrm{m} / \mathrm{yr}$ [7 to $10 \mathrm{mil} / \mathrm{yr}$ ] [4.15] and in flowing seawater to range between 762 to $1524 \mu \mathrm{m} / \mathrm{yr}$ [30 to $60 \mathrm{mil} / \mathrm{yr}$ ] [4.11]. For copper alloys, including muntz metal, pitting depth rates on the order of 635 to $889 \mu \mathrm{m} / \mathrm{yr}$ [ 25 to $35 \mathrm{mil} / \mathrm{yr}$ ] have been observed in flowing seawater [4.11].

The most detrimental effect of tube sheet pitting is when the pitting occurs at the tube-totube sheet joint and any crevices at these locations. Therefore, if the tube sheet is subject to raw water applications, then pitting is a significant aging mechanism.

\section{Galvanic Corrosion}

Heat exchanger tubes are atlached to the tube sheet by an expansion process (i.e., rolled) and in some case this joint is welded. The tube sheets are welded to the heat exchanger shell and for U-tube heat exchangers a water box partition plate is welded to the tube sheet. Heat exchanger design specifications require that materials of construction be compatible and that galvanic couples betweer adjacent materials are minimized. Additionally, in many instances sacrificial anodes are inst;.lled or, some other form of cathodic protection is provided to minimize the affects of galvanic ccrosion.

Therefore, irrespective of service application, if the heat exchanger tube sheet and all other components connected to the tube sheet are manufactured from materials that are close together on the galvanic series chart (Table 4-2), then galvanic corrosion is not a significant aging 
mechanism for the heat exchanger tube sheets. If the heat exchanger tube sheet and other components connected to the tube sheet are not manufactured from materials that are close together on the galvanic series chart; but sacrificial anodes or cathodic protection is adequately provided, then galvanic corrosion is not a significant aging mechanism for the heat exchanger tube sheets.

\section{Microbiologically Influenced Corrosion}

From References 4.3 and 4.11 and industry data presented in Section $3.6 \mathrm{MIC}$ is a significant aging mechanism for heat exchanger tube sheets in the scope of this AMG. MIC is most prominent in raw water applications, however, in treated water applications and closed cooling water applications (not treated with biocides) significant quantities of microbiological activity may be present. Mechanical crevices produce environments conducive both to growth of bacteria and localized abiotic corrosion [4.3]. The tube-to-tube sheet joint is one of the more common locations where heat exchanger failures are attributed to MIC.

MIC effects on copper alloys, particularly muntz metal, involve attack of the corrosion film by the metabolic products of the particular organisms. Ammonia, organic acids, and sulfides are the most common MIC waste products whose effects on copper based alloys are well documented [4.3]. MIC of stainless steel is characterized by severe pitting with preferential attack occurring at weldment (i.e., typically tube-to-tube sheet welds). The MIC effects on carbon and low alloy steel may result in random pitting, general corrosion or severe hydraulic effects due to the formation of tubercules and massive corrosion product deposits. Pitting under tubercules is common in carbon steels and exhibits no preference for a particular micro-structural constituent.

Therefore, irrespective of the materials, if the heat exchanger tube sheets are exposed to raw water applications, treated water applications, or closed cooling water applications (not chemically treated with inhibitors and biocides), then MIC is a significant aging mechanism.

\subsection{Stress Corrosion Cracking}

Very few incidents of stress corrosion cracking were identified in Section 3.6 as the primary cause of heat exchanger failures. One reason for this is because stress corrosion cracking must propagate over relatively long periods of time for failure to occur, and for heat exchanger tube sheets other aging mechanisms (i.e., fouling, corrosion, erosion/corrosion, etc.) and the corresponding failure mode occurs much more rapidly.

From Figure 4-2 if BWR plant primary water (i.e., non-borated reactor coolant) is greater than or equal to approximately $177^{\circ} \mathrm{C}\left[350^{\circ} \mathrm{F}\right]$ and dissolved oxygen is greater than or equal to $100 \mathrm{ppb}$ then conditions are right for IGSCC to occur in stainless steel materials. The RWCU regenerative heat exchanger tube sheet material is stainless steel exposed to reactor coolant temperature of $288^{\circ} \mathrm{C}\left[550^{\circ} \mathrm{F}\right]$. Dissolved oxygen content of BWR primary coolant (i.e., from the reactor recirculation system to the RWCU regenerative heat exchanger) can range between 50 to $300 \mathrm{ppb}$ during power operation. Therefore, IGSCC of the stainless steel BWR plant RWCU regenerative heat exchanger tube sheet is a significant aging mechanism. 
All stainless steel materials exposed to PWR plant primary water applications (i.e., borated reactor coolant in the CVCS and RHR system) are susceptible to IGSCC. Alternating wet and dry periods will allow concentration of boron on the heat exchanger tube sheet and further accelerate the rate of IGSCC. Therefore, IGSCC is a significant aging mechanism for the PWR plant CVCS regenerative, letdown, excess letdown, and seal water heat exchanger tube sheets and RHR heat exchanger tube sheets.

Chloride and sulfates significantly increase the potential for IGSCC to occur in stainless steel materials [4.14]. Chlorides and sulfates are present in raw fresh water applications and chloride levels are very high in raw brackish and seawater applications. Heat exchangers in these raw water environments may be exposed to alternate wet and dry periods which will allow concentration of the chloride containing salts on the tube sheets. Therefore, if the heat exchanger tube sheets are stainless steel and exposed to raw water, then IGSCC is a significant aging mechanism.

The copper alloy muntz metal heat exchanger tube sheets evaluated in this AMG contain approximately $60 \%$ copper and $40 \%$ zinc. A zinc content of greater than $15 \%$ is required for IGSCC and TGSCC to occur in highly oxygenated water. Therefore, if the heat exchanger tube sheet is manufactured from muntz metal and the tube sheet is exposed to either raw water, treated water, or closed cooling water, then IGSCC and TGSCC are significant aging mechanisms.

\subsection{Erosion and Erosion/Corrosion}

From Section 3.6 erosion and erosion/corrosion represent approximately $20 \%$ to $25 \%$ of the total number of heat exchanger failures caused by aging. Several cases of tube sheet erosion were identified from the NPRDS and LER data. An overwhelming majority were associated with carbon steel and muntz metal tube sheets where raw water flows into the waterbox and through the tubes. In these cases the raw water, which is a corrosive fluid, also contains highly abrasive fine particles of sand and silt that impinge on the tube sheet surface. Therefore, if the tube sheet is made from carbon steel or muntz metal and is exposed to raw water applications, then erosion and erosion/corrosion are significant aging mechanisms.

Closed cooling water and primary water applications (see Tables 3-5 and 3-6) are fine filtered to remove particulate and deionized to achieve purity. Dissolved oxygen levels in primary water applications are controlled to minimize accumulation of abrasive corrosion products and to maintain a protective oxide layer. In closed cooling water applications corrosion inhibitors are maintained in solution to minimize accumulation of corrosion products. Bulk fluid velocity at the tube sheet surface is much lower than the velocity inside the tubes which, from Section 4.3.2.1.5, ranges from 0.6 to $2.1 \mathrm{~m} / \mathrm{s}$ [ 1.9 to $6.9 \mathrm{ft} / \mathrm{s}]$. Cavitation at the tube sheet surface under these flow conditions, will not occur. Therefore, if the heat exchanger tube sheet is exposed to either closed cooling water or primary water and the water quality is properly maintained to minimize corrosion products in the fluid stream, then erosion and erosion/corrosion are not significant aging mechanisms irrespective of tube sheet material.

Treated water applications contain fine corrosion products that will collect at the bottom of tanks and reservoirs. These particles are highly abrasive and can be pumped into the heat exchanger waterbox and impinge the tube sheet, particularly if the pump suction lines originate 
at the bottom of the tank/reservoir. Treated water is considered to be a corrosive fluid due to its high dissolved oxygen content and particulate. Therefore, if the heat exchanger tube sheet is made from either muntz metal or carbon steel and is exposed to treated water, then crosion and erosion/corrosion are significant aging mechanisms.

Some plant drywell coolers/reactor building room coolers/containment atmosphere coolers are designed with headers as opposed to tube sheets. From Tables 3-5 and 3-6 the tube side (and therefore the header) flow is either raw water or closed cooling water. The evaluations above for these water applications also apply to the appropriate air cooler headers.

\subsection{Wear}

Mechanical tube sheet wear occurs when tubes vibrate within the tube sheet hole. Tube sheets made of muntz metal, carbon steel, or stainless steel are more wear resistant than the tubes. However, with prolonged tube vibrations it is possible to have fatigue cracks develop at the tube-to-tube sheet joint and propagate into the ligament (see Section 4.3.2.2.2). Therefore, wear is a significant aging mechanism for the heat exchanger tube sheet.

\subsection{Fouling}

From Section 3.6 fouling is the most predominant aging mechanism to adversely affect heat exchanger performance. NPRDS data shows that fouling accounts for $31 \%$ of the total number of heat exchanger failures while the LER data shows fouling as the primary cause in $44 \%$ of the heat exchanger failures.

Cases of biological and particulate fouling have been noted in raw water heat exchanger applications. Silt, sand, seaweed, clams, etc., can settle and collect on the tube sheet surface and block flow. If the heat exchangers are exposed to raw water, particularly brackish or seawater, and are alternately wetted and dried for any reason, then salts can precipitate and plate out on the tube sheet surfaces and cause fouling.

In treated water applications and lubricating oil applications corrosion product particulate can accumulate at the bottom of tank or reservoirs. When the systems are operated these particulates may be swept up and carried into the heat exchanger waterbox. The particulate can then deposit on the tube sheet and cause fouling.

PWR plant primary water is borated to control reactivity. This borated fluid flows through the waterbox and tube side of the CVCS heat exchangers (regenerative, letdown, excess letdown, and seal water) and the RHR system heat exchangers. If these heat exchangers are alternately wetted and dried for any reason then the boron can precipitate and plate out on the tube sheet surfaces and cause fouling.

Therefore, if the heat exchanger tube sheets are exposed to raw water, subject to PWR plant primary water, or located in treated water or lubricating oil applications where the fluid supply originates at the bottom of a tank or reservoir, then fouling is a significant aging mechanism irrespective of tube sheet material. 


\subsubsection{Shell/Nozzles/Internals}

Figures 3-1 and 3-2 depict typical heat exchangers used in the nuclear industry. From these figures it is evident that there are few other heat exchanger internal components and that the tube bundle consumes most of the internal volume. The other internal components whose degradation from aging could adversely impact heat exchanger performance are the impingement plates, baffles, tube support plates, tie rods and spacers, and, in some applications, floating heads. The shell side internals are manufactured from either carbon steel or stainless steel (Table 3-3) and are exposed to the various process fluids as shown on Tables 3-5 and 3-6. The heat exchanger shell and nozzles are also made of either carbon steel or stainless steel depending on the application.

From the Section 4.3.1 evaluations some aging mechanisms were determined to be not significant and several aging mechanisms required further evaluation. This section provides further evaluation of those aging mechanisms that may cause shell/nozzle/internals degradation. From Section 4.3.1 the heat exchangers shell/nozzle/internals are susceptible to:

- Thermal embrittlement and creep of all shell/nozzles/internals materials (Table 3-3) in those heat exchanger applications operating continuously at temperatures greater than $93^{\circ} \mathrm{C}\left[200^{\circ} \mathrm{F}\right]$ (Section 4.3.1.1).

- Mechanical fatigue of all shell/nozzles/internals material in all heat exchanger applications (Section 4.3.1.4).

- General corrosion of carbon and low alloy shell/nozzles/internals material exposed to treated water, raw water, and closed cooling water applications; and lubricating oil applications if the purity is not maintained (Section 4.3.1.5.1).

- General corrosion of stainless and high alloy shell/nozzles/internals material in raw water applications (Section 4.3.1.5.1).

- Pitting of carbon and low alloy steel and stainless and high alloy steel shell/nozzles/ internals material in raw water applications (Section 4.3.1.5.2).

- Galvanic corrosion of carbon and low alloy shell/nozzles/internals material in primary water, treated water, and raw water applications (Section 4.3.1.5.3).

- MIC of stainless and high alloy steel and carbon and low alloy steel shell/nozzles/internals materials in treated water and raw water applications and in closed cooling water applications not treated with biocides (Section 4.3.1.5.4).

- IGSCC of stainless and high alloy shell/nozzles/internals material in primary water applications where the temperature is greater than $177^{\circ} \mathrm{C}\left[350^{\circ} \mathrm{F}\right]$, in raw water applications, and in PWR plant primary water applications that operate at less than $177^{\circ} \mathrm{C}\left[350^{\circ} \mathrm{F}\right]$ (i.e., borated fluid) (Section 4.3.1.6.1). 
- Erosion and erosion/corrosion of carbon and low alloy steel shell/nozzles/internals material in treated water, closed cooling water and raw water applications; and stainless and high alloy shell/nozzles/internals material subject to severe turbulence or cavitation (Section 4.3.1.7).

- Fouling of shell/nozzles/internals in raw water applications, treated water and lubricating oil applications only where the supply originates at the bottom of a taik or reservoir, and in PWR plant primary water applications (Section 4.3.1.9).

\subsection{Thermal Embrittlement and Creep}

The BWR plant RWCU regenerative heat exchanger shell/nozzle/internals and the PWR plant CVCS regenerative, letdown and excess letdown heat exchanger shell/nozzles/internals are continuously exposed to reactor coolant temperatures ranging from $288^{\circ}$ to $316^{\circ} \mathrm{C}\left[550^{\circ}\right.$ to $600^{\circ} \mathrm{F}$. Shell/nozzles/internals in these heat exchangers are stainless steel because they are located in the reactor coolant fluid stream.

From Section 4.2.5.1 and Reference 4.5 thermal embrittlement is a concern for cast (duplex) austenitic stainless steel materials. Stainless steel heat exchanger shell/nozzles/internals are either manufactured as a forging or are made from rolled plate but they are not manufactured as a casting. Therefore, thermal embrittlement is not a significant aging mechanism for stainless steel heat exchanger shell/nozzles/internals without conditions.

Creep of a metal is dependent on temperatures, stress level, and length of time exposed to concurrent high temperature and stress. The effects of creep are particularly important if the temperature is greater than the recrystallization temperature is approximately 49 percent of the material's melting temperature or $538^{\circ} \mathrm{C}\left[1000^{\circ} \mathrm{F}\right]$. Therefore, if the heat exchanger shell/nozzles/ internals are manufactured from stainless steel, then creep is not a significant aging mechanism without condition.

\subsection{Mechanical Fatigue}

Over $12 \%$ of the NPRDS reported aging failures were associated with heat exchanger shells/nozzles/internals, but from Section 3.6, fatigue and vibration represent only about $5 \%$ of the total number of heat exchanger failures caused by aging.

From Section 4.3.1.4 heat exchanger shell/nozzles/internals are subject to mechanical and hydraulic stressors from the process fluid stream. These stressors (i.e., cyclic loads) are applicd to the heat exchanger shell/nozzles/internals when the unit is placed into service and removed from service, when undergoing load changes, and when operating under steady state conditions.

The tube support plate and baffle plate holes are drilled to accommodate the tight fitting heat exchanger tubes. Residual stress in these plates exist from the manufacturer process. The tube support plate and baffle plate are aligned to the tube sheet and connected to the tube sheet with tie rods and spacers. These tie rods are threaded and subject to tension load. Shell nozzle loading can cause high stresses in nozzle-to-shell welds. Impingement plates are generally welded to the shell inside surface. Industry experiences shows that these plates have exhibited 
fatigue cracks. Therefore, mechanical fatigue is a significant aging mechanism for the heat exchanger shells/nozzles/internals in all service applications regardless of materials and operating characteristics (i.e., continuously or intermittently operated).

\subsection{Corrosion}

From Tables 3-3 the heat exchanger shell/nozzles/internals within the scope of this AMG are manufactured from either carbon and low alloy steel or stainless stecl.

\section{General Corrosion}

From Tables 3-5 and 3-6 there are no heat exchangers in the scope of this AMG where raw water is used as the process fluid flowing through the shell side. Therefore, general corrosion of the heat exchanger shell/nozzles/internals is not relevant for this application.

General corrosion of carbon and low alloy steel in aqueous environments is well documented and the rate is dependent upon the fluid oxygen content, temperature, and flow rate. The highest general corrosion rates for carbon steel occur under conditions where the fluid is at ambient temperature, saturated with dissolved oxygen, and located in stagnant or slow moving fluid streams 14.111. Very little general corrosion of carbon steel occurs in high temperature water or steam applications because a thin black oxide film (i.e., magnetite) forms and rapidly protects the shell side metal surface from further corrosion. General corrosion of carbon steel in lubricating oil applications is very low because oxygen content is low, oils are not good electrolytes, and purification systems are generally installed and/or corrosion inhibitors are added to maintain the oil free of corrosion products.

In treated water and closed cooling water applications carbon and low alloy steel can experience uniform corrosion rates of 25 to $50 \mu \mathrm{m} / \mathrm{yr} / 1$ to $2 \mathrm{mil} / \mathrm{yr}$ ] or greater and localized corrosion (i.e., pitting) may be significantly greater. Many of the heat exchangers within the scope of this AMG, where the shell side fluid is either treated water or closed cooling water, are maintained full of fluid and isolated (i.e., standby operation) or mabe alternately wet and dry. The dry periods will allow concentration of salts and other corrosive constituents to deposit on the shell side metal surfaces. Therefore, if the heat exchanger shell/nozzles/internals are made of carbon and low alloy steel and exposed to either treated water or closed cooling water, then general corrosion is a significant aging mechanism. Tables 3-5 and 3-6 identify the various shell side process fluids that are exposed to the shell/nozzles/internals.

\section{Pitting Corrosion}

From Tables 3-5 and 3-6 there are no heat exchangers in the scope of this AMG where raw water is used as the process fluid flowing through the shell side. Therefore, pitting corrosion of the heat exchanger shell/nozzles/internals is not relevant for this application.

\section{Galvanic Corrosion}

From Section 3.6 only about $1 \%$ of the total number of aging failures were attributed to galvanic corrosion. The basic reason for this is because heat exchanger design specifications 
require that materials of construction be compatible and that galvanic couples between adjacent materials are minimized. Additionally, in many instances sacrificial anodes are installed or some other form of cathodic protection is provided to minimize the affects of galvanic corrosion.

All shell/nozzles/internals material in primary water applications is stainless steel and the other heat exchanger components that are connected to the shell/nozzles/internals, such as the tubes and tube sheet, are also stainless steel. Therefore, if the heat exchanger shell side components are exposed to primary water, then galvanic corrosion is not a significant aging mechanism without condition.

The shell/nozzles/internals in treated water applications are made from carbon and low alloy steels. In many of these applications the heat exchanger components that are in contact with the shell/nozzles/internals, such as the tubes and tube sheet, are made from either stainless steel or a copper alloy (i.e., muntz metal, inhibited admiralty brass or copper-nickel). In this case, galvanic corrosion of the carbon and low alloy steel components (i.e., more anodic material) could be a problem particularly if sacrificial anodes are not installed.

Therefore, in treated water applications, if the heat exchanger shell/nozzles/internals and all other components connected to the shell/nozzles/internals are manufactured from materials that are close together on the galvanic series chart (Table 4-2), then galvanic corrosion is not a significant aging mechanism. Also, in reated water applications, if the heat exchanger shell/ nozzles/internals and other components connected to the shell/nozzles/internals are not manufactured from materials that are close together on the galvanic series chart, and sacrificial anodes or cathodic protection is not provided, then galvanic corrosion of the carbon and low alloy steel materials is a significant aging mechanism.

\section{Microbiologically Influenced Corrosion}

From References 4.3 and 4.11 and industry data presented in Section 3.6, MIC is a significant aging mechanism for the shell/nozzles/internals of heat exchangers in the scope of this AMG. In treated water applications and closed cooling water applications (not treated with biocides) significant quantities of microbiologically activity may be present. Tables 3-5 and 3-6 show the heat exchangers with treated water and closed cooling water on the shell side. Mechanical crevices produce environments conducive both to growth of bacteria and localized abiotic corrosion [4.3]. The tube-to-tube support plate joint is one of the more common locations where MIC can occur.

MIC of stainless steel is characterized by severe pitting with preferential attack occurring at weldments. MIC of carbon and low alloy steel may result in random pitting, general corrosion, or severe hydraulic affects due to the formation of tubercules and massive corrosion product deposits. Pitting under tubercules is common in carbon steels and exhibits no preference for a particular microstructural constituent. Therefore, irrespective of the materials, if the heat exchanger shell/nozzles/internals are exposed to treated water applications or closed cooling water applications (not chemically treated with inhibitors and biocides), then MIC is a significant aging mechanism. 


\subsection{Stress Corrosion Cracking}

Very few incidents of stress corrosion cracking were identified in Section 3.6 as the primary cause of heat exchanger failures. One reason for this is because stress corrosion cracking must propagate over relatively long periods of time for failure to occur and for heat exchanger snell/nozzles/internals other aging mechanisms (i.e., fouling, corrosion, erosion/corrosion, etc.) and the corresponding failure mode occurs much more rapidly.

From Figure 4-2 if BWR plant primary water (i.e., non-borated reactor coolant) is greater than or equal to approximately $177^{\circ} \mathrm{C}\left[350^{\circ} \mathrm{F}\right]$ and dissolved oxygen is greater than or equal to $100 \mathrm{ppb}$ then conditions are right for intergranular stress corrosion cracking (IGSCC) to occur in stainless steel materials. The RWCU regenerative heat exchanger shell/nozzles/internals material is stainless steel and operate at reactor coolant temperature of $288^{\circ} \mathrm{C}\left[550^{\circ} \mathrm{F}\right]$. Dissolved oxygen content of BWR primary coolant (i.e., from the reactor recirculation to the RWCU regenerative heat exchanger) can range between 50 to $300 \mathrm{ppb}$ during power operation. Therefore, IGSCC of stainless steel BWR plant RWCU regenerative heat exchanger shell/ nozzles/internals is a significant aging mechanism.

All stainless steel materials exposed to PWR plant primary water applications (i.e., borated reactor coolant in the CVCS) are susceptible to IGSCC. Alternating wet and dry periods will allow concentration of boron on the heat exchanger shell/nozzles/internals and further accelerate the rate of IGSCC. Therefore, IGSCC is a significant aging mechanism for the PWR plant CVCS regenerative, letdown, excess letdown, and seal water heat exchanger shell/nozzles/ internals.

From Tables 3-5 and 3-6 there are no heat exchangers in the scope of this AMG where raw water is used as the process fluid flowing through the shell side. Therefore, IGSCC of the heat exchanger shell/nozzles/internals manufactured from stainless steel is not relevant for this application.

\subsection{Erosion and Erosion/Corrosion}

From Section 3.6 erosion and erosion/corrosion represent approximately $20 \%$ to $25 \%$ of the total number of heat exchanger failures caused by aging. An overwhelming majority, however, were associated with the tube side in raw water applications. From Tables 3-5 and 3-6 there are no heat exchangers in the scope of this AMG where raw water is used as the process fluid flowing through the shell side. Therefore, erosion and erosion/corrosion of the heat exchanger shell/nozzles/internals is not relevant for this application.

Strict controls are placed on the quality/purity of lubricating oil. The chemical properties of these oils are regularly checked. Impurities and particulate matter, which contributes to erosion and erosion/corrosion, are monitored and corrective actions implemented if oil quality/purity fails to meet acceptance standards. From Tables 3-5 and 3-6 all heat exchangers in the scope of this AMG that contain lubricating oil are operated with the lubricating oil on the shell side. Therefore, if chemical properties of the lubricating oil are regularly checked, then erosion and erosion/corrosion of the heat exchanger shell/nozzles/internals are not significant aging mechanisms. 
Closed cooling water and primary water applications (see Tables 3-5 and 3-6) are fine fittered to remove particulates and deionized to achieve purity. Dissolved oxygen levels in primary water applications are controlled to minimize accumulation of abrasive corrosion products and to maintain a protective oxide layer. In closed cooling water applications corrosion inhibitors are maintained in solution to minimize accumulation of corrosion products. A review of several different heat exchanger manufacturer specification sheets shows that shell side fluid velocity ranges from 0.9 to $2.7 \mathrm{~m} / \mathrm{s}$ [ 2.9 to $9.0 \mathrm{ft} / \mathrm{s}$ ]. This data also shows that where higher design shell side fluid velocities exist (i.e., $\geq 1.8 \mathrm{~m} / \mathrm{s}[6 \mathrm{ft} / \mathrm{s}]$ ), the heat exchanger shell/ nozzles/internals are usually made from stainless steel. If the heat exchanger shell/nozzles/ internals are made from carbon steel and are exposed to fluid velocity greater than $1.8 \mathrm{~m} / \mathrm{s}$ [6 ft/s] then the protective oxide film that is normally formed on these metal surfaces may be eroded away to bare metal. Therefore, if the heat exchanger shell/nozzles/internals are made from carbon steel and exposed to either closed cooling water or primary water where shell side fluid velocity is greater than $1.8 \mathrm{~m} / \mathrm{s}[6 \mathrm{ft} / \mathrm{s}]$, then erosion and erosion/corrosion are significant aging mechanisms.

The only heat exchanger application in the scope of this AMG utilizing treated water on the shell side is the BWR plant RHR heat exchangers (see Tables 3-5 and 3-6). Carbon steel shell/nozzles/internals are used in all BWR RHR heat exchanger applications. Shell side fluid is supplied predominantly from the suppression pool which is classified as treated water. Treated water contains fine corrosion products that will collect at the bottom of the suppression pool. These particles are highly abrasive and can be pumped into the heat exchanger shell side and impinge the internal surfaces, particularly if the RHR pump suction line originates at the hottom of the suppression pool. Treated water is considered to be a corrosive fluid due to its high dissolved oxygen content. The RHR system is primarily operated (i.e., monthly or quarterly) to support plant Technical Specification surveillance testing. The total operating time to complete a surveillance test typically ranges from two to eight hours. The total accumulated operating time that these RHR heat exchangers are exposed to treated water is, therefore, very low. Also, it is not uncommon to isolate the heat exchangers during these tests. The RHR heal exchangers are also exposed to a mode of operation called decay heat removal. In this mode, primary water flows in the shell side. Primary water does not contain abrasive corrosion products, however, if shell side fluid velocity exceeds the specified limits then the protective oxide layer formed on the carbon steel shell/nozzles/internals may begin to erode. Therefore, if the RHR heat exchanger shell/nozzles/internals are made from carbon steel and exposed to treated water and/or primary water and shell side flow rate is not maintained within specified limits, then erosion and erosion/corrosion are significant aging mechanisms.

\subsection{Fouling}

From Tables 3-5 and 3-6 there are no heat exchangers in the scope of this AMG where raw water is used as the process fluid flowing through the shell side. Therefore, fouling of the heat exchanger shell/nozzles/internals is not relevant for this application.

In treated water applications and lubricating oil applications corrosion product particulate can accumulate at the bottom of tanks or reservoirs. When the systems are operated these particulates may be swept up and carried into the heat exchanger shell. The particulate can then settle out and deposit on the shell/nozzles/internals surfaces and cause fouling. Therefore, if the 
heat exchanger shell/nozzles/internals are exposed to treated water or lubricating oil applications where the fluid supply originates at the bottom of a tank or reservoir, then fouling is a significant aging mechanism.

PWR plant primary water is horated to control reactivity. This borated fluid flows through the shell side of the CVCS regenerative heat exchanger. If these heal exchangers are alternately wetted and dried, then precipitate fouling will occur to the heal exchanger shell/ nozzles/internals. Therefore, if the heat exchanger shell/nozzles/internals are exposed to PWR plant primary water and alternately wetted and dried, then fouling is a significant aging mechanism.

\subsubsection{Waterbox/Channel Head/Divider Plate}

The heat exchanger waterbox/channel head/divider plate assembly is exposed to the cooling fluid media as shown on Tables 3-5 and 3-6. Figures 3-1 and 3-2 depict typical (1-tube and straight tube heat exchangers, respectively. The waterbox/channel head/divider plate are shown on Figure 3-1 (items 12, 13, 15, and 16). These components are manufactured from cither carbon steel or stainless steel (Table 3-3).

From the Section 4.3.1 evaluations some aging mechanisms were determined to be not significant and several aging mechanisms required further evaluation. This section provides further evaluation of those aging mechanism that may cause waterbox/channel head/divider plate degradation. From Section 4.3.1, the heat exchanger waterbox/channel head/divider plate are susceptible to:

- Thermal embrittlement and creep of the waterbox/channel head/divider plate materials (Table 3-3) in those heat exchanger applications operating continuously at temperatures greater than $93^{\prime \prime} \mathrm{C}\left[200^{\circ} \mathrm{F}\right]$ (Section 4.3.1.1).

- Mechanical fatigue of the waterbox/channel head/divider plate materials in all heat exchanger applications (Section 4.3.1.4).

- General corrosion of carbon and low alloy waterbox/channel head/divider plate material exposed to treated water, raw water, and closed cooling water applications; and lubricating oil applications if the purity is not maintained (Section 4.3.1.5.1).

- General corrosion of stainless and high alloy waterbox/channel head/divider plate material in raw water applications (Section 4.3.1.5.1).

- Pitting of carbon and low alloy steel and stainless and high alloy steel waterbox/ channel head/divider plate material in raw water applications (Section 4.3.1.5.2).

- Galvanic corrosion of carbon and low alloy steel waterbox/channel head/divider plate material in primary water, treated water, and raw water applications (Section $4.3 .1 .5 .3)$. 
- MIC of carbon and low alloy steel and stainless and high alloy steel waterbox/channel head/divider plate materials in treated water and raw water applications and in closed cooling water applications not treated with biocides (Section 4.3.1.5.4).

- IGSCC of stainless and high alloy steel waterbox/channel head/divider plate material in primary water applications where the temperature is greater than $177^{\circ} \mathrm{C}\left[350^{\circ} \mathrm{F}\right]$, in raw water applications, and in PWR plant primary water applications that operate at less than $177^{\circ} \mathrm{C} 1350^{\circ} \mathrm{F}$ (i.e., boraied Mluid) (Section 4.3.1.6.1).

- Erosion and crosion/corrosion of carbon and low alloy steel waterbox/channel head/ divider plate material in treated water, closed cooling water, and raw water applications; and stainless and high alloy steel waterbox/channel head/divider plate material subject to severe turbulence or cavitation (Section 4.3.1.7).

- Fouling of the heat exchanger waterbox/channel head/divider plate in raw water applications, and in treated water applications only where the supply originates at the bottom of a tank or reservoir; and in PWR plant primary water applications (Section $4.3 .1 .9)$.

\subsection{Thermal Embrittlement and Creep}

The BWR plant RWCU regenerative heat exchanger waterbox/channel head/divider plate and the PWR plant CVCS regenerative, letdown, and excess letdown heat exchanger waterbox/ channel head/divider plate are continuously exposed to reactor coolant temperatures ranging from $288^{\circ}$ to $316^{\circ} \mathrm{C}\left[550^{\circ}\right.$ to $\left.600^{\circ} \mathrm{F}\right]$. The waterbox/channel head/divider plate in these heat exchangers are stainless steel because they are located in the reactor coolant fluid stream.

From Section 4.2.5.1 and Reference 4.5 thermal embrittlement is a concern for cast (duplex) austenitic stainless steel materials. Stainless steel heat exchanger are either manufactured as a forging or are made from rolled plate but they are not manufactured as a casting. Therefore, thermal embrittlement is not a significant aging mechanism for stainless steel heat exchanger waterbox/channel head/divider plate without conditions.

Creep of a metal is dependent on temperature, stress level, and length of time exposed to concurrent high temperature and stress. The effects of creep are particularly important if the temperature is greater than the recrystallization temperature of the metal [4.2]. For stainiess stee] the recrystallization temperature is approximately 49 pereent of the material's melting temperature or $\left.538^{\circ} \mathrm{C} 11000^{\circ} \mathrm{F}\right]$. Therefore, if the heat exchanger waterbox/channel head/divider plate is manufactured from stainless steel, then creep is not a significant aging mechanism without condition.

\subsection{Mechanical Fatigue}

Over $8 \%$ of the NPRDS reported aging failures were associated with heat exchanger waterbox/channel head/divider plate, but from Section 3.6. fatigue and vibration represent only about 5\% of the cotal number of heat exchanger failures caused by aging. 
From Section 4.3.1.4 the heat exchanger waterbox/channel head/divider plate is subject to mechanical and hydraulic stressors from the cooling fluid stream. These stressors (i.e., cyclic loads) are applied when the unit is placed into service and removed from service, when undergoing load changes, and when operating under steady state conditions.

The waterbox on some heat exchangers within the scope of this AMG may be bolted in place. The holes drilled into the waterbox flange may result in some residual stress from this manufacturing process. The bolts may relax from their prestress condition (see Section 4.3.2.5.1) and cause the waterbox flange faces to separate slightly and vibrate. Waterbox/channel head nozzle loading from the cooling fluid piping can cause high stresses in the nozzle-to-waterbox welds. This divider plate is generally welded to the waterbox inside surface and tube sheet. Industry experience shows that these divider plate welds have exhibited fatigue cracks. Therefore, mechanical fatigue is a significant aging mechanism for the heat exchanger waterbox/channel head/divider plate in all service applications regardless of materials and operating characteristics (i.e., continuously or intermittently operated).

\subsection{Corrosion}

From Table 3-3 the heat exchanger waterbox/channel head/divider plate within the scope of this AMG are manufactured from either carbon and low alloy steel or stainless steel.

\section{General Corrosion}

From Tables 3-5 and 3-6 there are no heat exchangers in the scope of this AMG where lubricating oil is used as the cooling fluid flowing into the waterbox/channel head and through the tubes. Therefore, general corrosion of the waterbox/channel head/divider plate is not relevant for this application.

General corrosion of carbon and low alloy steel in aqueous environments is well documented and the rate is dependent upon the fluid oxygen content, temperature, and flow rate. The highest general corrosion rates for carbon steel occur under conditions where the fluid is at ambient temperature, saturated with dissolved oxygen, and located in stagnant or slow moving fluid streams [4.11]. Very little general corrosion of carbon steel occurs in high temperature water or steam applications because a thin black oxide film (i.e., magnetite) forms and rapidly protects the waterbox/channel head/divider plate surface from further corrosion.

In treated water and closed cooling water applications carbon and low alloy steel can experience uniform corrosion rates of 25 to $50 \mu \mathrm{m} / \mathrm{yr}$ [1 to $2 \mathrm{mil} / \mathrm{yr}$ ] or greater and localized corrosion (i.e., pitting) may be significantly greater. Some raw water applications are quite aggressive with regard to uniform corrosion and corrosion rates may be $254 \mu \mathrm{m} / \mathrm{yr}$ [10 mil/yr] or greater $[4.25,4.26]$. Localized pitting may be much more severe in these raw water applications. Many of the heat exchangers in the scope of this AMG, where the tube side cooling fluid is either treated water, closed cooling water, or raw water are maintained full of fluid and isolated (i.e., standby operation) or they may he drained. Alternating wet and dry periods will allow concentration of salts and other corrosive constituents to deposit on the waterbox/channel head/divider plate surfaces. Therefore, if the heat exchanger waterbox/channel head/divider plate are made of carbon and low allow steel and exposed to either treated water, 
closed cooling water, or raw water, then general corrosion is a significant aging mechanism. Tables 3-5 and 3-6 identify the various tube side cooling fluids that are exposed to the waterbox/channel head/divider plate.

Corrosion of stainless steel in raw water applications is affected by the chloride content of the water. When the raw water application is brackish or seawater and if heat transfer is into this fluid then corrosion of stainless steel is most severe. The corrosivity of a particular level of chloride solution can be strongly affected by other chemical constituents in the fluid. Test specimens of Type 304 stainless steel were exposed to flowing seawater $(0.6$ to $0.9 \mathrm{~m} / \mathrm{s} \mid 1$ to 2 $\mathrm{ft} / \mathrm{s}]$ ) for six months [4.24]. General corrosion rates range from 5.1 to $12.7 \mu \mathrm{m} / \mathrm{yr}[0.2$ to 0.5 mil/yr], however, local attack (i.e., pitting) was observed to be a maximum of $1270 \mu \mathrm{m}[50 \mathrm{mil}]$ in this six month time frame. Therefore, a stainless steel heat exchanger waterbox/channel head/ divider plate exposed to brackish or seawater would tend to fail from local perforation rather than from loss of wall thickness. Therefore, if the waterbox/channel head/divider plate is made from stainless steel and is exposed to raw water applications, then general corrosion is not a significant aging mechanism. Pitting, however, is evaluated in the next subsection of the AMG.

\section{Pitting Corrosion}

From Section 3.6 corrosion accounts for approximately $20 \%$ to $25 \%$ of the heat exchanger failures. Localized pitting is a major contributor to heat exchanger waterbox/channel head/ divider plate degradation. Pitting is aggravated by creviced locations (i.e., flanged surfaces) galvanic couples between materials, stagnation or low velocity fluid flow, deposit accumulation, etc. From the discussion above for general corrosion, stainless and high alloy steel and carbon and low alloy steel heat exchangers are all susceptible to pitting in raw water applications. Brackish and seawater tend to cause more severe pitting than does freshwater. For stainless and high alloy steel a threshold value of less than or equal to $5 \mathrm{ft} / \mathrm{s}$ tends to promote pitting in seawater applications $[4.11,4.23]$. For carbon and low alloy steels no lower threshold flow velocity could be identified above which pitting is not a concern.

From the discussion above for general corrosion, test specimens of Type 304 stainless steel in flowing seawater showed pitting depths to be a maximum of $1270 \mu \mathrm{m}[50 \mathrm{mil}]$ in a six month time frame 14.11]. Test specimens of carbon steel in flowing freshwater showed pitting depths to range between 178 to $254 \mu \mathrm{m} / \mathrm{yr}[7$ to $10 \mathrm{mil} / \mathrm{yr}$ ] [4.15] and in flowing seawater to range between 762 to $1524 \mu \mathrm{m} / \mathrm{yr}$ [30 to $60 \mathrm{mil} / \mathrm{yr}$ ] [4.11]. Therefore, if the waterbox/channel head/divider plate is subject to raw water applications, then pitting is a significant aging mechanism.

\section{Galvanic Corrosion}

From Section 3.6 only about $1 \%$ of the total number of aging failures were attributed to galvanic corrosion. The basic reason for this is because heat exchanger design specifications require that materials of construction be compatible and that galvanic couples between adjacent materials are minimized. Additionally, in many instances sacrificial anodes are installed or, some other form of cathodic protection is provided to minimize the affects of galvanic corrosion. 


\section{AGING MANAGEMENT GUIDELINE FOR HEAT EXCHANGERS}

All waterbox/channel head/divider plate material in primary water applications is stainless steel and the other heat exchanger components that are connected to the waterbox/channel head/ divider plate, such as the shell and tube sheet, are also stainless steel. Therefore, if the heat exchanger waterbox/channel head/divider plate is exposed to primary water, then galvanic corrosion is not a significant aging mechanism without condition.

The waterbox/channel head/divider plate in treated water and raw water applications are made from carbon and low alloy steels. In many of these applications the heat exchanger components that are in contact with the waterbox/channel head/divider plate, such as the shell and tube sheet are made from either carbon steel, stainless steel, or a copper alloy (i.e., muntz metal inhibited admiralty brass or copper-nickel). In these cases, galvanic corrosion of the carbon and low alloy steel components (i.e., more anodic material) could be a problem particularly if sacrificial anodes are not installed.

Therefore, in treated water and raw water applications, if the heat exchanger waterbox/ channel head/divider plate and all other components connected to the waterbox/channel head/ divider plate are manufactured from materials that are close together on the galvanic series chart (Table 4-2), then galvanic corrosion is not a significant aging mechanism. Also, in treated water and raw water applications, if the heat exchanger waterbox/channel head/divider plate and other components connected to the waterbox/channel head/divider plate are not manufactured from materials that are close together on the galvanic series chart; and sacrificial anodes or cathodic protection is not provided, then galvanic corrosion of the carbon and low alloy steel materials is a significant aging mechanism.

\section{Microbiologically Influenced Corrosion}

From References 4.3 and 4.11 and industry data presented in Section $3.6 \mathrm{MIC}$ is a significant aging mechanism for the waterbox/channel/head/divider plate of heat cxchangers in the scope of this AMG. MIC is most prominent in raw water applications, however, in treated water applications and closed cooling water applications (not treated with biocides) significant quantities of microbiological activity may be present. Tables 3-5 and 3-6 show the heat exchangers with raw water, treated water, and closed cooling water on the tube side. Mechanical crevices produce environments conducive both to growth of bacteria and localized abiotic corrosion [4.3]. The waterbox flanges are one of the more common locations where MIC can occur.

MIC of stainless steel is characterized by severe pitting with preferential attack occurring at weldments. MIC of carbon and low alloy steel may result in random pitting, general corrosion, or severe hydraulic effects due to the formation of tubercules and massive corrosion product deposits. Pitting under tubercules is common in carbon steels and exhibits no preference for a particular microstructural constituent. Therefore, irrespective of materials, if the heat exchanger are exposed to raw water applications, treated water applications, or closed cooling water applications (not chemically treated with inhibitors and biocides), then MIC is a significant aging mechanism. 


\subsection{Stress Corrosion Cracking}

Very few incidents of stress corrosion cracking were identified in Section 3.6 as the primary cause of heat exchanger failures. One reason for this is because stress corrosion cracking must propagate over relatively long periods of time for failure to occur, and for heat exchanger waterbox/channel head/divider plate other aging mechanisms (i.e., fouling, corrosion, erosion/ corrosion, etc,) and the corresponding failure mode occurs much more rapidly.

From Figure 4-2 if BWR plant primary water (i.e., borated reactor coolant) is greater than or equal to approximately $177^{\circ} \mathrm{C}\left[350^{\circ} \mathrm{F}\right]$ and dissolved oxygen is greater than or equal to 100 $\mathrm{ppb}$ then conditions are right for IGSCC to occur in stainless steel materials. The RWCU regenerative heat exchanger waterbox/channel head/divider plate material is stainless steel and operate at reactor coolant temperature of $288^{\circ} \mathrm{C}\left[550^{\circ} \mathrm{F}\right]$. Dissolved oxygen content of $\mathrm{BWR}$ primary coolant (i.e., from the reactor recirculation system to the RWCU regenerative heat exchanger) can range between 50 to $300 \mathrm{ppb}$ during power operation. Therefore, IGSCC of the stainless steel waterbox/channel head/divider plate is a significant aging mechanism.

All stainless steel materials exposed to PWR plant primary water applications (i.e., borated reactor coolant in the CVCS and RHR system) are susceptible to IGSCC. Alternating wet and dry periods will allow concentration of boron on the heat exchanger waterbox/channel head/divider plate and further accelerate the rate of IGSCC. Therefore, IGSCC is a significant aging mechanism for the PWR plant CVCS regenerative, letdown, excess letdown, and seal water heat exchanger and RHR heat exchanger waterbox/channel head/divider plate.

Chlorides and sulfates significantly increase the potential for IGSCC to occur in stainless steel materials [4.14]. Chlorides and sulfates are present in raw fresh water applications and chloride levels are very high in raw brackish and seawater applications. Heat exchangers in these raw water environments may be exposed to alternate wet and dry periods which will allow concentration of the chloride containing salts on the waterbox/channel head/divider plate. Therefore, if the heat exchanger waterbox/channel head/divider plate arc stainless steel and exposed to raw water, then IGSCC is a significant aging mechanism.

\subsection{Erosion and Erosion/Corrosion}

From Section 3.6 erosion and erosion/corrosion represent approximately $20 \%$ to $25 \%$ of the total number of heat exchanger failures caused by aging. Several cases of waterbox/channel head/divider plate erosion were identified from the NPRDS and LER data. An overwhelming majority were associated with carbon steel where raw water, which is a corrosive fluid, also contains highly abrasive fine particles of sand and silt that impinges on the waterbox and divider plate surfaces. Therefore, if the waterbox/channel head/divider plate is made from carbon steel and exposed to raw water applications, then erosion and erosion/corrosion are significant aging mechanisms.

Closed cooling water and primary water applications (see Tables 3-5 and 3-6) are fine filtered to remove particulates and deionized to achieve purity. Dissolved oxygen levels in primary water applications are controlled to minimize accumulation of abrasive corrosion products and to maintain the protective oxide layering. In closed cooling water applications 
corrosion inhibitors are maintained in solution to minimize accumulation of corrosion products. Bulk fluid velocity at the waterbox and divider plate surfaces is much lower than the velocity inside the tubes which, from Section 4.3.2.1.5, ranges from 0.6 to $2.1 \mathrm{~m} / \mathrm{s}$ [1.9 to $6.9 \mathrm{ft} / \mathrm{s}$ ]. Cavitation at the surfaces under these flow conditions will not occur. Therefore, if the heat exchanger waterbox/channel head/divider plate is exposed to either closed cooling water or properly maintained to minimize corrosion products in the fluid stream, then erosion and erosion/ corrosion are not significant aging mechanisms irrespective of the waterbox/channel head/divider plate material type.

Treated water applications contain fine corrosion products that will collect at the bottom of tanks and reservoirs. These particles are highly abrasive and can be pumped into the heat exchanger waterbox and impinge the waterbox/channel head/divider plate, particularly if the pump suction lines originate at the bottom of the tank/reservoir. Treated water is considered to be a corrosive fluid due to its high dissolved oxygen content. Therefore, if the heat exchanger waterbox/channel head/divider plate is made from carbon steel and is exposed to treated water, then erosion and erosion/corrosion are significant aging mechanisms.

Some plant drywell coolers/reactor building room coolers/containment atmosphere coolers are designed with headers rather than a waterbox/channel head/divider plate. From Tables 3-5 and 3-6 the tube side (and therefore the header) flow is either raw water or closed cooling water. The evaluations above for these water applications also apply to the appropriate air cooler headers.

\subsection{Fouling}

From Section 3.6 fouling is the most predominant aging mechanism to adversely affect heat exchanger performance. The NPRDS data shows that fouling accounts for $31 \%$ of the total number of heat exchanger failures while the LER data shows fouling as the primary cause in $44 \%$ of the heat exchanger failures.

Cases of biological and particulate fouling have been noted in raw water heat exchanger applications. Silt, sand, seaweed, clams, etc., can settle and collect on the waterbox/channel head/divider plate surfaces and block flow. If the heat exchangers are exposed to raw water, particularly brackish or seawater, and are alternately wetted and dried for any reason, then salts can precipitate and plate out onto the waterbox/channel head/divider plate surfaces and cause fouling.

In treated water applications corrosion product particulates can accumulate at the bottom of tanks or reservoirs. When the systems are operated these particulates may be swept up and carried into the heat exchanger waterbox. The particulates can then deposit on the waterbox/ channel head/divider plate and cause fouling.

PWR plant primary water is borated to control reactivity. This borated fluid flows through the waterbox and tube side of the CVCS heat exchangers (regenerative, letdown, excess letdown, and seal water) and RHR system heat exchangers. If these heat exchangers are alternately wetted and dried for any reason then the boron can precipitate and plate out onto the waterbox/channel head/divider plate surfaces and cause fouling. 
Therefore, if the heat exchanger are exposed to raw water, subject to PWR plant primary water, or located in treated water applications where the fluid supply originates at the bottom of a tank or reservoir, then fouling is a significant aging mechanism irrespective of waterbox/ channel head/divider plate material.

\subsubsection{Pressure Boundary Fasteners/Support Assembly}

The heat exchanger pressure boundary fasteners and support assembly are not exposed to either the process or cooling fluid media. These components are exposed to external ambient conditions. Figures 3-1 and 3-2 show the heat exchanger pressure boundary fasteners and support assembly. These components are manufactured from either carbon steel or stainless steel (Table 3-3).

From the Section 4.3.1 evaluations some aging mechanisms were determined to be not significant and several aging mechanisms required further evaluation. This section provides further evaluation of those aging mechanisms that may cause degradation to the fasteners and support assembly. From Section 4.3.1 the heat exchanger's pressure boundary fasteners/support assembly are susceptible to:

- Thermal embrittlement and creep of the pressure boundary fasteners and support assemblies and stress relaxation of the pressure boundary fastener materials (Table 3-3) in those heat exchanger applications operating continuously at temperatures greater than $93^{\circ} \mathrm{C}\left[200^{\circ} \mathrm{F}\right]$ (Section 4.3.1.1).

- Mechanical fatigue of the pressure boundary fasteners and support assembly materials in all heat exchanger applications (Section 4.3.1.4).

- General corrosion of the pressure boundary fasteners in PWR plant primary water applications (Section 4.3.1.5.1).

- Pitting of carbon and low alloy pressure houndary fasteners in raw water applications (Section 4.3.1.5.2).

- IGSCC of stainless and high alloy steel pressure boundary fasteners in primary water applications where the temperature is greater than $177^{\circ} \mathrm{C}\left[350^{\circ} \mathrm{F}\right]$, in raw water applications, and in PWR plant primary water applications that operate at less than $177^{\circ} \mathrm{C}\left[350^{\circ} \mathrm{F}\right]$ (i.e., borated fluid) (Section 4.3.1.6.1).

\subsection{Thermal Embrittlement, Stress Relaxation, and Creep}

The BWR plant RWCU regenerative heat exchangers and the PWR plant CVCS regenerative, letdown, and excess letdown heat exchangers are continuously exposed to reactor coolant temperatures ranging from $288^{\circ}$ to $316^{\circ} \mathrm{C}\left(550^{\circ}\right.$ to $600^{\circ} \mathrm{F} \mid$. The pressure boundary fasteners and support assembly are manufactured from stainless steel.

From Section 4.2.5.1 and Reference 4.5 thermal embrittlement is a concern for cast (duplex) austenitic stainless steel materials. Stainless steel heat exchanger pressure boundary 
fasteners are manufactured as a forging, and the support assemblies are made from rolled plate. These components are not manufactured as a casting. Therefore, thermal embrittlement is not a significant aging mechanism for stainless steel heat exchanger pressure boundary fasteners and support assemblies without conditions.

Creep of a metal is dependent on temperature, stress level, and length of time exposed to concurrent high temperature and stress. The effects of creep are particularly important if the temperature is greater than the recrystallization temperature of the metal [4.2]. For stainless steel, the recrystallization temperature is approximately 49 percent of the material's melting temperature or $538^{\circ} \mathrm{C}\left[1000^{\circ} \mathrm{F}\right]$. Therefore, if the heat exchanger pressure boundary fasteners and support assemblies are manufactured from stainless steel, then creep is not a significant aging mechanism without condition.

The pressure boundary fasteners in these primary water applications are used primarily to fasten the waterbox to the shell. These bolted fasteners are continuously exposed to normal operating temperatures ranging from $288^{\circ}$ to $316^{\circ} \mathrm{C}\left[550^{\circ}\right.$ to $\left.600^{\circ} \mathrm{F}\right]$ and to flow induced cyclic loading. These fasteners are prestressed when tightened and the amount of stress depends upon the applied torque and efficiency of the threads. When operating at these temperatures, over long periods of time, the fastener may undergo small amounts of plastic deformation (i.e., stress, relaxation). Therefore, stress relaxation is a significant aging mechanism for pressure boundary fasteners in primary water applications.

\subsection{Mechanical Fatigue}

Less than 1\% of the NPRDS reported aging failures were associated with pressure boundary fasteners and no support assembly failures were reported, but from Section 3.6, fatigue and vibration represent only about $5 \%$ of the total number of heat exchanger failures caused by aging.

When a number of fasteners are employed in joining together two parts, the load carried by each fastener depends on its relative tightness, with the tighter bolts carrying greater loads. When operating at high temperatures, the fastener could undergo small amounts of plastic deformation (i.e., stress relaxation). If enough fasteners undergo stress relaxation the clamping force of the joint could be lost and the fasteners could be subjected to mechanical fatigue due to vibration and hydraulic stresses. This is unlikely to occur because stress relaxation of stainless steel fasteners, at temperatures ranging from $288^{\circ}$ to $316^{\circ} \mathrm{C}$ [ $\left[550^{\circ}\right.$ to $600^{\circ} \mathrm{F}$ ], occurs very slowly unless the fasteners are prestressed to a valve above the yield point of the material. Therefore, if stress relaxation is effectively managed and the pressure boundary fasteners are not prestressed above the yield point, then mechanical fatigue of the heat exchanger pressure boundary fasteners is not a significant aging mechanism.

\subsection{Corrosion}

From Table 3-3 the heat exchanger pressure boundary fasteners within the scope of this AMG are manufactured from either forged carbon steel or forged stainless steel. The fasteners in primary water applications arc all stainless steel. 


\section{General Corrosion}

In the event of a flange leak in PWR plant primary water applications, stainless sted fasteners would be exposed to the borated fluid. Industry experience shows that borated fluid is highly corrosive and that stainless steel is not immune to general corrosion from this fluid. Therefore, if the heat exchanger is located in PWR plant primary water applications, then general corrosion of heat exchanger pressure boundary fasteners is a significant aging mechanism.

\section{Pitting Corrosion}

From Section 3.6 corrosion accounts for approximately $20 \%$ to $25 \%$ of the heat exchanger failures. Localized pitting is a contributor to heat exchanger pressure boundary fastener degradation. Pitting is aggravated by creviced locations (i.e., bolt threads) and deposit accumulation. Carbon steel pressure boundary fasteners are susceptible to pilting in raw water fluids. In the event of a flange leak in raw water applications this corrosive fluid would be exposed to the carbon steel pressure boundary fasteners. Brackish and seawalter tend to cause more severe pitting than does freshwater. Therefore, if the heat exchanger pressure boundary fasteners are made from carbon steel and located in raw water applications, then pitting corrosion is a significant aging mechanism.

\subsection{Stress Corrosion Cracking}

Very few incidents of stress corrosion cracking were identified in Section 3.6 as the primary catuse of heat exchanger failures. The reason for this is because stress corrosion cracking must propagate over relatively long periods of time for failure to oceur, and for heat exchanger pressure boundary fasteners other aging mechanisms (i.e., corrosion, pitting, etc.) and the corresponding failure mode occurs more rapidly. From Table 3-15 less than $1 \%$ of all heal exchanger failures were associated with fasteners, and no cases of IGSCC were identified in the LER and NPRDS data searches (see Section 3.6). Therefore, IGSCC of the heat exchanger pressure boundary fasteners is not a significant aging mechanism without conditions.

\subsubsection{Aging Mechanism Synergies and Dependencies}

This section provides a basic understanding of aging mechanism synergy, which is the effect caused by several aging mechanisms acting together. The root cause of heat exchanger failure caused by aging mechanism synergies and dependencies can be difficult to identify. This section does not evaluate specific aging mechanism synergies and dependencies occurring on the various heat exchanger subassemblies.

Aging mechanisms were evaluated in Section 4.3.1 and 4.3.2, as if they manifested individually on a specific heat exchanger component. Both theoretical considerations and field history indicate that the effects of two or more aging mechanisms acting simultancously on a component may cause degradation and failure. The time duration of significant degradation to occur under these conditions will be less than the duration for each individually acting aging mechanism. 
Corrosion and erosion can both result in material wastage. Acting together they can reduce material thickness to the point where excessive deformation or complete failure occurs. Significant material thickness reductions have occurred in turbulent regions of heat exchanger shells, tubes, and waterbox assemblies.

The surface discontinuities caused by localized corrosion can increase the peak stresses caused by cyclic loads. This combination of aging mechanisms termed corrosion fatigue has been addressed in the literature [4.27] and is applicable to heat exchanger pressure boundary components.

Heat exchangers require that many subcomponents work together to provide satisfactory performance. The aging mechanisms evaluated in Sections 4.3.1 and 4.3.2 do not consider the dependence between aging mechanisms and components. There are many situations where aging and degradation of one heat exchanger component can be the primary reason for degradation of a different component. For example, fouling of the tube sheet can cause some tubes to be plugged and exhibit increased velocity (i.e., erosion) in the tubes which are not plugged.

\subsubsection{Comparison of AMG with NPAR Results}

Several NPAR reports that evaluate aging and degradation of nuclear plant heat exchangers have been written for the NRC. The NPAR reports that cover heat exchanger aging/degradation are identified in References 4.28, 4.29, 4.30, 4.31, 4.32, $4.33,4.34$, and 4.35 .

Reference 4.30 presents the results of an assessment associated with time-related degradation (i.e., aging) of non-power cycle heat exchangers (1) used in safety-related systems or (2) that provide normal operating capability in the nuclear power plant. Aging information was obtained from various sources of nuclear plant operating experience documentation. The events were categorized by heat exchanger function, failure, type and failure cause. Table 5-1 of Reference 4.30 shows the results of this aging assessment. The results of this aging assessment compare favorably to the evaluations of aging mechanism significance found in Section 4.3.1 and 4.3.2 of this AMG. From Reference 4.30 tube degradation due to fouling, corrosion, erosion and mechanical fatigue were found to be the overwhelming cause of the majority of heat exchanger failures. The AMG identified all of these aging mechanisms as significant contributors to tube degradation that require maintenance, inspection, and testing programs to detect the degradation.

The only difference between the findings presented in Reference 4.30 and the evaluations presented in this AMG deal with heat exchanger gasket failures. From Reference 4.30 gasket failures accounted for approximately $13.5 \%$ of the total failures from the LER and NPRDS databases combined. Also, gasket failures generally do not adversely affect the ability of the heat exchanger to performing its required function. In the $\mathrm{AMG}$ gaskets are considered to be renewable items that are regularly replaced. No attempt was made in the AMG to determine the percentage of gasket failures or to evaluate aging mechanisms and degradation of heat exchanger gaskets. 
A review of the other NPAR documents (References 4.28, 4.29, 4.31, 4.32, 4.33, 4.34, and 4.35) confirmed that the aging mechanism evaluations presented in Section 4.3.1 and 4.3.2 of the AMG, compare favorably. No new or different stressors, and the corresponding aging mechanisms, were identified to be significant in these NPAR documents.

\subsection{References}

4.1 Heat Exchanger Institute, Inc., "Standard for Power Plant Heat Exchangers," First Edition, 1980.

4.2 Metals Handbook Ninth Edition, Volume 11, "Failure Analysis and Prevention," American Society for Metals, Copyright 1986, pp. 130-133, 203-208, 150-154.

4.3 EPRI Research Project RP-2812-2, "Sourcebook for Microbiologically Influenced Corrosion in Nuclear Power Plants," Structural Integrity Associates, Inc., 1988.

4.4 EPRI Report NP-7154, "Summary of BWR Owner's Group Intergranular Stress Corrosion Cracking Research Program 1979-1988," February 1991, pp. 5-50, 5-51, 6-21 through 6-23.

4.5 NUMARC Report Number 90-09, "BWR Primary Coolant Pressure Boundary License Renewal Industry Report," April 1992, pp. 4-1 through 4-55.

4.6 G. Cragnolino and D.D. MacDonald. "Intergranular Stress Corrosion Cracking of Austenitic Stainless Steel at Temperatures Below $100^{\circ} \mathrm{C}-\mathrm{A}$ Review," National Association of Corrosion Engineers, Volume 38. Number 8. August 1982. pp. 406-408.

4.7 J.K. Lee and Z. Szklarska - Smialowska, "Stress Corrosion Cracking of Sensitized AISI 304 Stainless Steel in Aqueous Chloride Solutions Containing Sulfur Species at $50^{\circ}$ through $200^{\circ} \mathrm{C}$," National Association of Corrosion Engineers, Volume 44, Number 8, August 1988, pp. 564.

4.8 NUMARC Report Number 90-03, "Boiling Water Reactor Vessel Internals License Renewal Industry Report," June 1992.

4.9 NUMARC Report Number 90-02. "Boiling Water Reactor Vessel License Renewal Industry Report," August 1992.

4.10 NUMARC Report Number 90-07, "PWR Reactor Coolant System Licensc Renewal Industry Report," May 1992.

4.11 Metals Handbook Ninth Edition, Volume 13, "Corrosion," American Society for Metals, Copyright 1987, pp. 935-936.

4.12 EPRI Report NP-3673-LD, "Long-Term Integrity of Nuclear Power Plant Components," October 1984, pp. 1-1, 2-44 through 2-50. 
4.13 EPRI Report TR-100385, "Balance-of-Plant Heat Exchanger Condition Assessment Guidelines," July 1992, Appendix D.

4.14 Stress Corrosion Cracking - Material Performance and Evaluation, American Society of Materials, 1992, Chapters 1 and 4.

4.15 Metals Handbook Ninth Edition, Volume I, "Properties and Selection: Irons and Steels," American Society for Metals, Copyright 1978, p. 701.

4.16 B.A. Garrett-Price, et al. "Fouling of Heat Exchangers - Characteristics, Costs, Prevention, Control, and Removal," Copyright 1985 by Noyes Publications.

4.17 ASME OM-S/G-1994: "Standard and Guides for Operation and Maintenance of" Nuclear Power Plants, Part 21." (in preparation)

4.18 Bednar, Henry H., "Pressure Vessel Design Handbook," Van Nostraud Reinwald Company, 1981, p. 270.

4.19 EPRI NP-5181 SP Volume 1, "BWR Pilot Plant Life Extension Study at the Monticello Plant: Phase 1, Volume 1: Appendices," Final Report, May 1987.

4.20 NUREG/CR-4652, "Concrete Component Aging and Its Significance Relative to Life Extension," D. Naus, Oak Ridge National Laboratory, September 1986.

4.21 EPRI NP-5181 SP Volume 2, "BWR Pilot Plant Life Extension Study at the Monticello Plant: Phase 1," pp. 1-3 to 1-13, 1987.

4.22 American Society for Testing and Materials STP 756, 1982, "Intergranular Stress Corrosion Cracking Resistance of Austenitic Stainless Steel Castings," by N.R. Hughes, W.L. Clarke, and D.E. Delwicke.

4.23 Metals Handbook Ninth Edition, Volume 2, "Properties and Selection: Nonferrous Alloys and Pure Metals," American Society for Metals, Copyright 1987. pp. $470-472$.

4.24 Metals Handbook Ninth Edition, Volume 3, "Properties and Selection: Stainless Steels, Tool Materials and Special - Purpose Metals," American Society for Metals, Copyright 1987.

4.25 EPRI NP-7240, "In-Plant Electrochemical and Corrosion Studies of Service Water Systems," March 1991.

4.26 NRC Information Notice No. 90-39, "Recent Problems with Service Water Systems," June 1, 1990.

4.27 Nuclear Regulatory Commission, Branch Technical Position PDLR D- I, "Fatigue Evaluation Procedures," Draft, December 12, 1991. 
4.28 NUREG/CR-5052, J.C. Higgins, R. Lofaro, M. Subudhi, R. Fullwood, and J.H. Taylor, "Operating Experience and Aging Assessment of Component Cooling Water Systems in Pressurized Water Reactors," Brookhaven National Laboratory, BNL-NUREG-52117, July 1988.

4.29 NUREG/CR-5693, R. Lofaro, W. Gunther, M. Subudhi, B. Lee, "Aging Assessment of Component Cooling Water Systems in Pressurized Water Reactors," Brookhaven National Laboratory, BNL-NUREG-52283, June 1992.

4.30 NUREG/CR-5779, J.C. Moyers, "Aging of Non-Power-Cycle Heat Exchangers Used in Nuclear Power Plants," Oak Ridge National Laboratory, ORNL-6687/VI, Draft Volume 1, April 1992.

4.31 PNL-5722, D.E. Blahnik and R.L. Goodman, "Operating Experience and Aging Assessment of ECCS Pump Room Coolers," Pacific Northwest Laboratory, October 1986.

4.32 NUREG/CR-5268, R. Lofaro, M. Subudhi, W.E. Gunther, W. Shier, R. Fullwood, and J.H. Taylor, "Aging Study of Boiling Water Reactor Residual Heat Removal System," BNL-NUREG-52177, Brookhaven National Laboratory, June 1989.

4.33 NUREG/CR-5379, D.B. Jarrell, A.B. Johnson Jr., P.W. Zimmerman, and M.L. Gore, "Nuclear Plant Service Water System Aging Degradation Assessment: Phase 1," Volume 1, Pacific Northwest Laboratory, PNL-6560, June 1989.

4.34 NUREG/CR-4967, L.C. Meyer, "Nuclear Plant Aging Research on High Pressure Injection Systems," Idaho National Engineering Laboratory, EGG-2514, August 1989.

4.35 NUREG/CR-5057, K.R. Hoopingarner and F.R. Zaloudek, "Aging Mitigation and Improved Programs for Nuclear Service Diesel Generators," Pacific Northwest Laboratory, PNL-6397, December 1989. 


\section{EFFECTIVE MANAGEMENT OF AGING MECHANISMS}

An effective program for addressing heat exchanger degradation will provide for both understanding and managing the aging mechanisms. Key elements of an effective program reflect the technical aging issues and potential consequences of the aging process being mitigated.

Aging mechanisms and their effects must be understood with sufficient accuracy and detail to provide the basis for developing and implementing aging management strategies that address actual or potential root causes of heat exchanger failures. The requisite understanding may be either empirical or mechanistic, depending on the nature and potential consequences of a particular aging mechanism. An understanding of degradation requires a detailed awareness of heat exchanger design, fabrication, installation, testing, inservice operation, and maintenance cycles. Degradation of heat exchangers is a time dependent phenomena that depends on the interactions of materials with environmental and operational stressors.

\subsection{Generic Elements of an Effective Aging Management Program}

Continued safe nuclear plant operation requires that heat exchangers evaluated in this AMG continue to reliably function throughout their service life. Degradation of a heat exchanger is a regulatory concern when the heat exchanger normally functions to ensure plant safety and the degradation progresses to the point of impaired safety performance.

The License Renewal Rule [5.1] requires that nuclear plant components, including heat exchangers, be subject to programs that effectively manage component degradation and their associated aging mechanisms. The Maintenance Rule [5.2] requires that nuclear plant components, including heat exchangers, meet specified performance parameters. In addition, quality assurance criteria $[5.3]$ requires development and implementation of programs to ensure that conditions adverse to quality, including degraded heat exchanger performance, are promptly identified and corrected.

Criteria have been established for determining if a plant program is effective for detecting and mitigating the effects of aging. These criteria are provided in Reference 5.1 and state that a program is effective if:

- The program is documented, its implementing procedures are approved by on-site review committees, and it is implemented in accordance with plant administrative procedures, and

- The program procedures ensure that the component's required functions are properly addressed considering the effects of age-related degradation, as appropriate, and

- The program establishes specific acceptance criteria against which the need for corrective action is to be evaluated and requires timely corrective actions to be taken when the acceptance criteria are not met. 
Reference 5.2 states in part under paragraph [A] [1] "Each holder of an operating license . . . shall monitor the performance or condition of SSCs . . . in a manner sufficient to provide reasonable assurance that SSCs . . a are capable of fulfilling their intended functions."

Paragraph [A] [2] of Reference 5.2 states in part "Monitoring . . is not required where it has been demonstrated that the performance or condition of a SSC is being effectively controlled through the performance of appropriate preventive maintenance, such that the SSC remains capable of performing its intended function."

The three criteria for determining program effectiveness are broken down into distinct categories. The following provides further guidance for each category to determine if a program satisfies the criteria.

\subsubsection{Program is Documented}

The criteria for a program to be documented satisfies 10 CFR 50 Appendix B - Quality Assurance Criteria [5.3] which states in part "Every applicant for an operating license is required to include, in its final safety analysis report, information pertaining to the managerial and administrative controls to be used to assure safe operation." Therefore, a program being documented means that specific commitments have been and are included on the respective plant docket. Docketed commitments are included in the updated final safety analysis report, responses to generic letters, I.E. Bulletins, Orders, 10 CFR 50.59 evaluations, notices of violations, open items, etc., and any other programmatic or procedural commitment made to ensure compliance with the Code of Federal Regulations.

\subsubsection{Program Implementing Procedures Approved by Operations Review Committee and Program Implemented Via Administrative Procedures}

These two criteria for procedural approvals and administration of the program also satisfy 10 CFR 50 Appendix B [5.31. Item I. - Organization of this Appendix states in part "the authority and duties of persons and organizations performing activities affecting the safety related functions of structures, systems, and components shall be clearly established and delineated in writing." This Appendix further states in Item II - Quality Assurance Program, that "This program shall be documented by written policies, procedures, or instructions and shall be carried out throughout plant life in accordance with those policies, procedures, or instructions."

Each program must be documented with written policies (i.e., administrative procedures) and the program implementing procedures must be reviewed and approved by on-site review committees to ensure that activities affecting the required function of heat exchangers are correctly performed.

\subsubsection{Component's Required Functions Properly Addressed}

Each heat exchanger evaluated in this AMG either provides a support function or directly functions to prevent or mitigate the consequences of postulated accidents that could cause undue risks to the health and safety of the public. Methods by which a heat exchanger accomplishes 
these actions are termed required functions. A heat exchanger may have only one or several required functions.

The required function(s) for each heat exchanger are identified in the program implementing procedures. The scope and content of all program implementing procedures credited for elfective management of aging are reviewed by knowledgeable plant personnel to ensure that aging mechanisms and degradation, affecting the capability of the heat exchanger to satisfy its required function(s), are adequately detected and mitigated.

\subsubsection{Age-Related Degradation Effects Properly Addressed}

All aging mechanisms occurring to these heat exchangers will manifest and progress at different rates and are affected by many variables such as material composition, operating service conditions, environmental parameters, geometric configuration, etc. As such, program implementing procedures must be performed at a frequency commensurate with the rate of aging to ensure detection and mitigation of degradation. Detection and mitigation of degradation provides assurance that the heat exchanger required function will not be compromised during its service life. Inspection, test, replacement, and refurbishment procedures are performed at frequencies which are based on code requirements, regulatory specifications, vendor recommendations, industry experience, observations by knowledgeable plant personnel, etc. and can be adjusted as experience dictates.

\subsubsection{Acceptance Criteria Established to Determine Need for Corrective Action, Corrective Actions Specified, and Timely Action Taken}

These three criteria dealing with acceptance criteria and corrective actions also satisfy 10 CFR 50 Appendix B [5.3]. Item V states in part that "Instructions, procedures, or drawings shall include appropriate quantitative and quantitative acceptance criteria for determining that important activities have been satisfactorily accomplished." Item XVI. Corrective Action, states that "Measures shall be established to assure that conditions adverse to quality are promptly identified and corrected."

All program implementing procedures shall contain acceptance criteria in the form of recorded data, documented observances, procedural step signoffs, etc. to demonstrate that activities performed on heat exchangers for detecting and mitigating degradation have been either satisfactorily accomplished or corrective actions identified to ensure required function capability.

The corrective actions required may encompass a wide range of activities which cannot be clearly identified in the program implementing procedure. Provisions shall be made, however, to document what corrective actions were taken. These corrective actions may be in the form of references to work request, additional diagnosis, retesting, non-destructive examinations, etc.

Program administrative procedures and/or specific implementing procedures shall provide guidance relative to the timeless of corrective actions taken. This guidance shall be considered with respect to the aggressiveness of the aging mechanism (i.e., rate of degraded performance or function) and the frequency of program activities to detect and mitigate degradation. 
Performing timely corrective action ensures that heat exchanger required functions are not compromised throughout the heat exchanger's service life.

\subsubsection{Program Effectiveness Matrix}

Table 5-1 can be used 10 document the evaluation of a program and corresponding implementing procedures to effectively detect and mitigate heat exchanger age-related degradation.

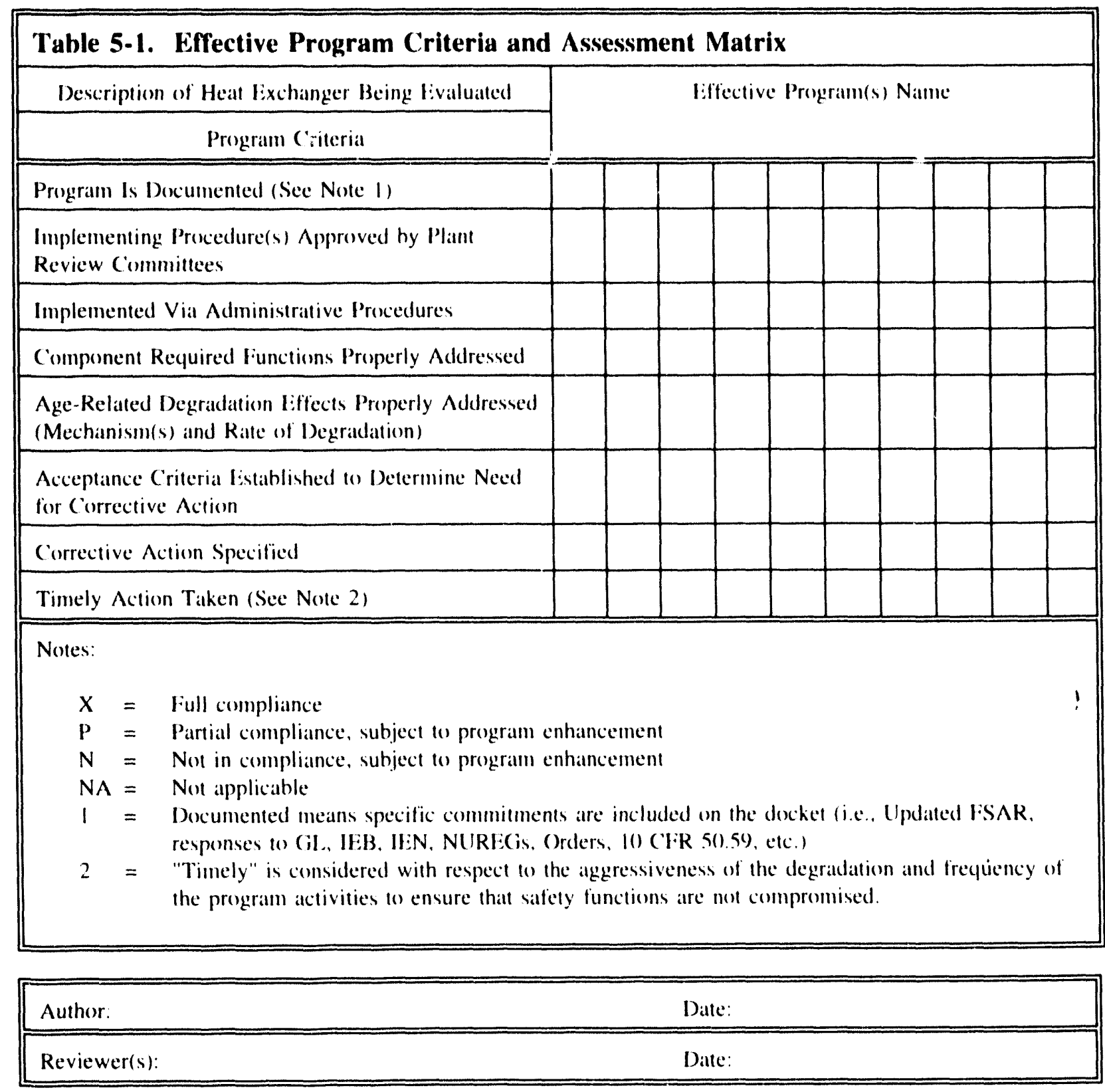




\subsection{Conventional Effective Programs Commonly Used in the Industry}

Demonstrating the adequacy of plant procedures to detect and mitigate degradation is accomplished by (1) substantiating that established programs and procedures effectively ensure the capability of the associated heat exchangers to perform their required function(s) throughout their entire service life, or (2) taking actions in the form of program and/or procedural enhancements necessary to manage the aging mechanism(s) which are not adequately addressed by current established programs and/or procedures. Adequacy of programs and procedures for detecting and mitigating degradation must be demonstrated for each heat exchanger using one of these methods.

It is recognized that many heat exchangers are subject to a variety of inspection, test, replacement and/or refurbishment programs to address diverse functional requirements and various aging mechanisms. As such, to establish the adequacy of existing plant programs, several programs may be required for a given heat exchanger. Through a combination of such programs, as necessary, the basis for safe and reliable operation throughout the heat exchanger's entire service life can be established.

Following is a discussion of the commonly used maintenance and surveillance programs determined from other aging studies to be effective in detecting aging mechanisms and mitigating the degradation of heat exchangers within acceptable limits.

\subsubsection{ASME Section XI Inservice Inspection Program}

Section XI of the ASME Code [5.4] provides the rules and requirements for inservice inspection, repair, and replacement of Class 1,2 , and 3 pressure retaining components, including heat exchangers. All heat exchangers evaluated in this AMG are either Class 2 or 3 . Class 1 heat exchangers are not included in the scope. Classes 2 and 3 refer to components constructed in accordance with the rules of ASME Section III. Section XI categorizes the areas subject to inspection and defines responsibilities, provisions for accessibility, examination methods and procedures, personnel qualifications, frequency of inspection, record keeping and reporting requirements, procedures for evaluation of inspection results, disposition of results, and repair requirements. Section XI, Article IWC applies to Class 2 components, and Article IWD applies to Class 3 components.

\subsubsection{Class 2 Heat Exchangers}

The ASME Section XI examination requirements for Class 2 heat exchangers are as follows [5.5].

\section{Shell}

Volumetric examination of $100 \%$ of the heat exchanger shell circumferential welds, headto-shell-circumferential welds, tube sheet-to-shell weld, and any gross structural discontinuity (for example, shell-to-flange welds, junctions between shells of different thickness, and cylindrical shell-to-conical shell junctions). In the case of multiple heat exchangers of similar design, size, function, and operating service, the required examinations may be limited to one heat exchanger 
or distributed among the heat exchangers. The heat exchanger areas initially selected for examination shall be reexamined each inspection interval over the service life of the heat exchanger.

\section{Nozzle}

- In those situations where the heat exchanger shell nominal wall thickness is less than or equal to $12.7 \mathrm{~mm}$ [0.50 in], surface examination (liquid penetrant or magnetite particle) is performed on the nozzle-to-shell weld.

- In those situations where the heat exchanger nozzle is not equipped with a reinforcing plate and the shell nominal wall thickness is greater than $12.7 \mathrm{~mm}[0.50 \mathrm{in}]$ :

a. Surface and volumetric examination is performed on the nozzle-to-shell weld, and

b. Volumetric examination is performed on the nozzle inside radius section.

- In those situations where the heat exchanger nozzle is equipped with a reinforcing plate and the shell nominal wall thickness is greater than $12.7 \mathrm{~mm}[0.50 \mathrm{in}]$ :

a. Surface examination is performed on the reinforcing plate-to-nozzle welds and reinforcing plate-to-shell welds, and

b. Volumetric examination is performed on the nozzle-to-shell welds when the heat exchanger shell internals are accessible, and

c. Visual (VT-2) examination is performed on the nozzle-to-shell welds when the heat exchanger shell internals are not accessible.

For all of the above situations regarding nozzle examinations, if multiple heat exchangers of similar design, size, function, and operating service exist, then these required examinations may be limited to one heat exchanger or distributed among the heat exchangers. Also, the heat exchanger nozzles initially selected for examination shall be reexamined each inspection interval over the service life of the heat exchanger.

\section{Integral Attachments}

Surface (liquid penetrant or magnetite particle) examination is performed on those integrally welded attachments that meet all of the following conditions:

- The attachment is on the outside surface of the heat exchanger,

- The attachment provides support for the heat exchanger,

- The attachment base material design thickness is $19.05 \mathrm{~mm}[0.75 \mathrm{in}]$ or greater, and 
- The attachment weld joins the attachment either directly to the surface of the heat exchanger or to an integrally cast or forged attachment to the heat exchanger.

The extent of the examination includes $100 \%$ of the required areas of each welded attachment. In the case of multiple heat exchangers of similar design, size, function, and operating service, the required examination may be limited to one heat exchanger. Where multiple heat exchangers are provided with a number of similar attachments, the required examinations may be distributed among the heat exchangers. The areas of the welded attachment initially selected for examination shall be reexamined each inspection interval over the service life of the attachment.

\section{Fasteners}

Volumetric examination is performed on heat exchanger pressure retaining bolts and studs that are greater than two inches in diameter. The examinations may be performed on these fasteners either in place under load or upon disassembly of the connection. The examination of fasteners may be conducted on one heat exchanger among a group of heat exchangers in each system required to be examined which are similar in design, size, function, and operating service. Also, where one heat exchanger to be examined contains a group of bolted connections of similar design and size (such as a flanged connection) the examinations may be conducted on one bolted connection among the group. The heat exchanger fasteners initially selected for examination shall be re-examined each inspection interval over the service life of the fastener.

\section{Pressure Testing}

The pressure retaining component (i.e., heat exchanger shell) within each Class 2 system boundary shall be subject to visual (VT-2) examination during system pressure testing. A leakage test shall be conducted at least once each 40-month inspection period at a test pressure equal to the nominal operating pressure during system operation. A hydrostatic test shall be performed at or near the end of each inspection interval at a value not to exceed $125 \%$ of normal operating pressure depending on the test temperature of the fluid. In lieu of a hydrostatic test the requirements of ASME Code Case N-498 [5.6] can be performed.

\subsubsection{Class 3 Heat Exchangers}

The ASME Section XI examination requirements for Class 3 heat exchangers are as follows [5.7].

\section{Integral Attachments}

Visual (VT-3) examination is performed on those integrally welded attachments that meet all of the following conditions:

- The attachment is on the outside surface of the heat exchanger, and

- The attachment provides support for the heat exchanger, and 
- The attachment weld joins the attachment either directly to the surface of the heat exchanger or to an integrally cast or forged attachment to the heat exchanger.

The extent of the examination includes $100 \%$ of the required areas of each welded attachment. In the case of multiple heat exchangers of similar design, size, function, and operating service, the required examination may be limited to one heat exchanger. Where multiple heat exchangers are provided with a number of similar attachments, the required examinations may be distributed among the heat exchangers. The areas of the welded attachment initially selected for examination shall be re-examined each inspection interval over the service life of the attachment.

\section{Pressure Testing}

The pressure retaining component (i.e., heat exchanger shell) within each Class 3 system boundary shall be subject to visual (VT-2) examination during system pressure testing. A leakage test shall be conducted at least once each 40-month inspection period at a test pressure equal to the nominal operating pressure during system operation. A hydrostatic test shall be performed at or near the end of each inspection interval at a value not to exceed $125 \%$ of normal operating pressure depending on the test temperature of the fluid.

\subsubsection{Heat Exchanger Repair/Replacement}

ASME Section XI also provides rules and requirements for the repair and replacement of Class 2 and 3 pressure retaining components including heat exchangers. A heat exchanger repair/replacement program is a document or sut of documents that defines the managerial and administrative control for completion of repairs or replacement of items. A repair/replacement plan is developed to identify a number of requirements to be adhered to while performing the repair/replacement. Some of the more significant requirements are:

- Applicable ASME Codes

- Description of the work to be performed including flaw characterization and flaw removal method

- Applicable weld procedures, nondestructive examinations, tests, and material requirements

- Applicable examinations, tests, and acceptance criteria to verify acceptability of the repair/replacement

- Intended life of the repair/replacement when less than the remainder of the design life of the heat exchanger

When repair or replacement is required because of failure, the evaluation shall consider the cause of failure to ensure that the selected repair or replacement is suitable. Repair/replacement activities shall reflect appropriate corrective provision to mitigate recurrence of the failure. 


\subsubsection{ASME Operation and Maintenance Code}

The committee on Operation and Maintenance of Nuclear Power Plants (O\&M Committee) is chartered to develop codes, standards, and guidelines for maintenance and testing of nuclear power plant equipment and components. The O\&M Committee is responsible for reviewing ASME Section XI to determine where O\&M codes can replace Section XI requirements. The following draft O\&M parts have not been endorsed by the Boiler and Pressure Vessel Committee of ASME nor have they been entered into the Code of Federal Regulation (10 CFR 50.55a) as mandatory testing and inspection requirements. Nuclear utilities, therefore, are not obligated to follow the requirements of these draft O\&M parts.

- Part 11 of Reference 5.8 "Vibration Testing and Assessment of Heat Exchangers" includes guidance for placement of instrumentation, steady-state and transient testing methods, data interpretation, and acceptance criteria for assessment of heat exchanger vibration. Guidelines are also provided to assist in evaluating component or system modification, operating limitations, more extensive testing, analysis or future monitoring of vibration.

- The O\&M Committee is in the process of developing another standard for nuclear plant heat exchangers. The intent of Part 21 "Inservice Performance Testing of Heat Exchangers in LWR Plants" [5.9] is to provide performance and functional testing and monitoring methods for heat exchangers to ensure that they meet their required function from a thermal performance standpoint.

These draft parts provide methods and guidance that will effectively manage aging occurring to nuclear plant heat exchangers. Since these draft parts are currently not mandatory requirements, the elements and activities contained within these draft parts are considered, for the purpose of this AMG, as preventive maintenance and discussed in Section 5.2.3.

\subsubsection{Preventive Maintenance Program}

Preventive maintenance $(P M)$ is defined as periodic, predictive, or planned activities performed on a heat exchanger prior to its failure. The objective of conducting PM is to sustain or extend the service life of a heat exchanger by controlling degradation and failures to an acceptable level.

Periodic maintenance activities are accomplished on a routine basis (typically based on operating hours, number of cycles, or calendar time). For heat exchangers, these activities include such items as replacement of gaskets and other renewable components, verification of fastener torque, and inspections for external leakage and/or other abnormal conditions.

Predictive maintenance activities involve continuous or periodic condition monitoring of heat exchanger operating parameters and/or functional performance testing of the heat exchanger. Elements of predictive maintenance also include data gathering, analysis, diagnosis, and trending to determine the material condition and performance characteristic of the heat exchanger. Typical predictive maintenance activities associated with heat exchangers include monitoring of vibration, thermal performance testing, pressure loss monitoring, eddy current testing, and leak testing. 
Planned maintenance activities are primarily scheduled on the basis of information obtained and trends derived from performing periodic and predictive maintenance. These activities consist of inspections, refurbishment, overhaul, and major part replacement and are conducted prior to heat exchanger failure. Also, planned maintenance activities can be identified and initiated based on vendor recommendations, industry operating experience, and plant specific operating and maintenance history.

The PM Program is governed by approved administrative controlling documents and conducted in accordance with detailed implementing procedures. PM plans are developed to outline task requirements and to coordinate scheduling and implementation of PM activities associated with all plant equipment encompassed by the program, including heat exchangers. The frequency of performing PM is dependent upon engineering assessments, plant/industry operating experience, environmental conditions, manufacturers recommendations, and feedback from maintenance personnel.

Completed PM activities are reviewed by cognizant personnel. The results are compared with acceptance criteria and timely corrective actions are initiated as appropriate. Data is extracted from the completed PM and analyzed for the purpose of detecting adverse trends. The frequency of performing a PM activity may be increased or decreased depending upon the observations made and conclusions drawn from review of the completed PM activity.

The following sections of the AMG (i.e., 5.2.3.1, 5.2.3.2.1 through 5.2.3.2.8, and 5.2.3.3.1) provide a simplistic and highly condensed version of the information contained in ASME OM Part 21 (i.e., Reference 5.9). The user of this AMG is cautioned to follow the requirements of ASME OM Part 21 as opposed to that which is presented in these sections. These sections are ONLY meant to give the reader a very broad overview of ASME OM Part 21 and are NOT considered, and shall NOT be used as the authority for heat exchanger prioritization, testing, monitoring, or visual inspections. That authority resides with ASME OM Part 21.

\subsubsection{Heat Exchanger PM Prioritization and Aging Management Intervals}

The order for testing, inspection, trending, and/or monitoring heat exchangers should be prioritized to maximize the use of available resources and to optimize overall plant availability and capacity. The following criteria should be progressively applied to the specific plant heat exchangers at appropriate intervals to achieve high availability and capacity.

- If a heat exchanger is served by a fluid that has a high potential for fouling (for example, service water), then that heat exchanger should be given top priority.

- If there are two or more heat exchangers in parallel, and all are subject to identical service conditions (i.e., same flow rate and heat load, inservice operating times are equalized, etc.), then only ne of the heat exchangers, initially, should be given top priority. If identical heat exchangers are in series, then the first one in the series should be given top priority. 
- If heat exchanger geometries and tube plugging levels are different, then tube velocities should be compared prior to determining which heat exchanger should be given top priority. The heat exchanger with the lowest calculated velocity should be given highest priority. If the fouling fluid is on the shell side, even where the heat exchangers are identical, then there is less predictability of individual heat exchanger performance.

- If a particular heat exchanger is experiencing degraded thermal performance, then this heat exchanger should be given top priority.

The intervals or frequency of performing the various aging management activities (i.e., testing, inspection, trending, and/or monitoring) should be initially established based upon baseline data, obtained on a clean or refurbished (i.e., "like new") heat exchanger, and subsequent tests and/or inspections. Trending and monitoring of heat exchanger performance should be utilized to adjust the intervals as required. Parameters such as fouling rate, type of fouling, operational demand, heat load capability, etc. should be used as a basis for adjusting the aging management activity intervals.

\subsubsection{Aging Management Methods}

Selection of the appropriate aging management methods to assess thermal performance characteristics for a particular heat exchanger should be made by examining several criteria for each method. The criteria for each method should be applied to each of the heat exchangers until, through the process of elimination, the most appropriate method is identified. The aging management methods to assess thermal performance characteristics for the heat exchangers are:

- Functional Testing

- Heat Transfer Coefficient Testing Without Phase Change

- Heat Transfer Coefficient Testing With Condensation

- Transient Testing

- Temperature Effectiveness Testing

- Batch Testing

- Temperature Difference Monitoring

- Pressure Loss Monitoring

\subsection{Functional Testing}

The objective of the functional test method is to provide an indication of thermal performance degradation of a heat exchanger over a period of time. This is accomplished by measuring a temperature that is dependent on the thermal performance of the heat exchanger (i.e., "temperature of interest") and to compare that temperature with established acceptance criteria. The "temperature of interest" is the temperature of a particular component or area of the plant that the heat exchanger is designed to cool.

This functional testing method may be used for heat exchangers: 
a. If the acceptance criteria of the heat exchanger is stated explicitly in terms of a "temperature of interest", and

b. If the design accident flows and inlet temperatures can be achieved during test conditions, and

c. If the heat exchanger can be subjected to the same or greater heat load that would be present under accident conditions, and

d. If steady state conditions exist.

The functional testing method is ideally suited for heat exchangers on a closed cooling loop system because the temperature of a closed cooling loop can be easily manipulated and controlled.

\subsection{Heat Transfer Coefficient Testing Without Phase Change}

The objective of the heat transfer coefficient test method without phase change is to determine the heat transfer capability of the heat exchanger when a fluid phase change is not occurring at test conditions. Cooling fluid inlet and outlet temperature and flow rate is measured as is the process fluid inlet and outlet temperature and flow rate. From this data a fouling resistance is calculated and the heat exchanger heat transfer capability is determined.

The heat transfer coefficient testing method may be used for heat exchangers:

a. If the design basis specifies heat exchanger function in terms of heat duty $(\mathrm{Btu} / \mathrm{hr})$, and

b. If sufficient parameter accuracy (i.e., temperature and flow data) is achievable at test conditions, and

c. If a fluid phase change does not occur at test conditions, and

d. If steady state conditions exist.

This heat transfer coefficient testing method may not be used for heat exchangers:

a. If the flow on the shell side traverses flow regimes (i.e., phase change) in going from the test condition to the design accident condition and inaccuracies can not be accounted for, or

b. If the fouling rate is so high that heat exchanger operability can not be maintained between tests.

For the heat transfer coefficient test method without a fluid phase change, first, the design film coefficients are calculated using the Mean Temperature Difference (MTD) Method. Second, the performance under test conditions is evaluated using either the MTD Method or the Number 
of Transfer Units (NTU) Method. Third, the projected heat transfer rate of a heat exchanger under design accident conditions is determined given the current fouling level measured under test conditions.

\subsection{Heat Transfer Coefficient Test Method With Condensation}

The objective of the heat transfer coefficient test method with condensation is to determine the heat transfer capability for heat exchangers having condensation from steam-air mixtures during test conditions. Process fluid (steam-air mixture) pressure, flow rate, inlet and outlet temperatures, and inlet and outlet relative humidity are measured. Also, the cooling fluid flow rate and inlet and outlet temperatures are measured. If the process fluid condensation rate can be measured, then this data should be obtained. From this data a fouling resistance is calculated and the heat exchanger heat transfer capability is determined.

The heat transfer coefficient testing method may be used for heat exchangers:

a. If the design basis specifies heat exchanger function in terms of heat duty (Btu/hr), and

b. If sufficient parameter accuracy (i.e., pressure, temperature, flow rate, relative humidity, and condensation rate) is achievable at test conditions, and

c. If condensation occurs during the test conditions, and

d. If steady state conditions exist.

This heat transfer coefficient testing method may not be used for heat exchangers:

a. If the flow on the shell side traverses flow regimes (i.e., phase change) in going from the test condition to the design accident condition and inaccuracies can not be accounted for, or

b. If the fouling rate is so high that heat exchanger operability can not be maintained between tests.

When heat transfer occurs from a steam-air mixture, the sensible heat transfer takes place because of a temperature difference and the mass transfer occurs because of a difference in steam partial pressure across the convection layer. Latent heat is released during condensation which penetrates across the tube wall to the cooling fluid inside the tubes. The condensation rate equals the mass transfer rate.

The intent of this method is to vary the fouling resistance until the calculated parameters match the measured parameters. The fouling resistance is then used to calculate the heat transfer rate under the design accident conditions. 


\subsection{Transient Test Method}

The objective of the transient test method is to determine the thermal performance of a heat exchanger when steady state conditions cannot be achieved during the test. This method will result in the calculation of a fouling resistance for the heat exchanger and the determination of heat exchanger heat transfer capability. Process fluid and cooling fluid inlet and outlet temperature and flow rate time history must be measured. Process fluid and cooling fluid initial temperature profile inside the heat exchanger must also be measured.

The transient test method refers to measuring the time it takes for temperatures to change in response to a transient heat load being placed on the heat exchanger. This method may be used where flow rates or inlet temperatures (or both) vary during the test.

The transient test method may be used for heat exchangers:

a. If the design basis specifies heat exchanger function in terms of heat duty $(\mathrm{Btu} / \mathrm{hr})$, and

b. If sufficient accuracy is achievable at test conditions, and

c. If an appreciable heat load is available such that process fluid temperatures can be raised, and

d. If a process fluid phase change does not occur at test conditions.

The transient test method may not be used for heat exchangers:

a. If the transient is a steep function of time, such that the thermal inertia of the heat exchanger becomes significant, or

b. If the value of thermal inertia can not be calculated, or

c. If the flow on the shell side traverses flow regimes (i.e., phase change) in going from the test condition to the design accident condition and inaccuracies can not be accounted for, or

d. If the fouling rate is so high that heat exchanger operability can not be maintained between tests, or

e. If significant condensation occurs at the test conditions.

The steady state temperature profiles of fluids inside a shell and tube heat exchanger during steady state can be represented by ordinary differential equations. If the specific heat is constant and if the overall heat transfer coefficient is uniform over the entire heat transfer surface, then these differential equations can be integrated. The relationships between boundary temperatures, flow rates, specific heat, overall heat transfer coefficient, and heat transfer can be 
found by using the Logarithmic-Mean Temperature Difference (LMTD) with correction factors applied. The correction factors are provided on F-P charts published by TEMA [5.10].

When a heat exchanger undergoes a transient, the temperature profile of shell and tube side fluids can be represented by partial differential equations. For arbitrarily specified timedependent boundary conditions of fluid inlet temperature or flow rates, a numerical integration (i.e., trial and error) must be performed.

\subsection{Temperature Effectiveness Test Method}

The temperature effectiveness test method is used to predict the effectiveness of the heat exchanger at a known reference point. This method assumes that the process and cooling fluid mass flow rates at the test point are essentially the same as those at the reference point (i.e., within $\pm 5 \%$ ). This method is accomplished by collecting the process and cooling fluid inlet and outlet temperatures at the test point, choosing two temperatures at the reference point, and calculating the remaining two temperatures at the reference point.

The temperature effectiveness is the ratio of the temperature change of the tube side fluid to the difference between the two fluid inlet temperatures (sometimes called temperature efficiency).

The temperature effectiveness test method may be used for heat exchangers:
a. If sufficient accuracy is achievable at test conditions, and
b. If both test flows can be manipulated to within $\pm .5 \%$ of the design accident flows, and
c. If design accident temperatures can not be achieved during test conditions, and
d. If steady state conditions exist.

The temperature effectiveness test method may not be used for heat exchangers if a phase change is expected to occur at either the test or design accident conditions.

The temperature effectiveness method is conservative if the design accident condition temperatures are higher than the test condition temperatures because of the improved heat transfer coefficient at higher temperatures.

\subsection{Batch Test Method}

The objective of the batch test method is to determine the temperature effectiveness and/or overall heat transfer coefficient of a heat exchanger by measuring the aggregate quantity of heat removed by the heat exchanger in the batch mode from a source of large thermal capacity.

The following parameters must be measured to quantitatively evaluate the heat exchanger thermal performance using the batch test method: 
- Mass of the Process Fluid

- Initial Process Fluid Inlet Temperature

- Final Process Fluid Inlet Temperature

- Process Fluid Flow Rate

- Cooling Fluid Inlet Temperature

- Cooling Fluid Flow Rate

- Time Required to Cool the Process Fluid

The batch test method may be used for heat exchangers:

a. If sufficient accuracy is achievable at test conditions, and

b. If the temperature of the process fluid reservoir can be measured as a function of lime, and

c. If the fluid in the process fluid reservoir is well mixed, and

d. If the heat exchanger is the sole medium for the enthalpy change in the process fluid reservoir during the test, and

e. If steady state conditions do not exist.

The batch test method may not he used for heat exchangers:

a. If the flow on the shell side traverses flow regimes (i.c., phase change) in going from the test condition to the design accident condition and inaccuracies can not be accounted for, or

b. If the fouling rate of the heat exchanger is excessive such that the overall heat transfer of the heat exchanger is changed during the test, or

c. If the fluid in the process fluid reservoir undergoes a phase change, or

d. If the flow rate or inlet temperature of the cooling fiuid is subject to variation during the test.

The batch test method can be used when steady state test conditions can not be achieved. This method is accomplished by measuring the initial process fluid and final process fluid reservoir temperatures over a measured time period, while holding the cooling fluid inlet temperature constant. Using the thermal capacity of the process fluid reservoir, the temperature effectiveness and/or overall heat transfer coefficient can be calculated.

\subsection{Temperature Difference Monitoring Method}

The objective of the temperature difference monitoring method is to provide an indication of thermal performance degradation of a heat exchanger over time by monitoring the relationship 
between the temperature of interest and the inlet temperature of the cooling fluid. The cooling fluid inlet temperature and temperature of interest must be monitored.

The temperature difference monitoring method may be used for heat exchangers:

a. If the equipment loads and the process temperatures and flows that create the heat load of the heat exchanger are of the same magnitude for each test, and

b. If heat loads and flows can be repeatedly achieved for each test, and

c. If steady state conditions exist.

The temperature difference monitoring method may not be used for heat exchangers if the heat exchanger operating margin is known to be generally small.

While heat exchanger coolant temperatures fluctuate (e.g., due to seasonal temperature changes), an indication of heat exchanger thermal performance may be obtained by monitoring the temperature of interest and the heat exchanger cooling fluid inlet temperature. Based on accumulated operating experience, a correlation between these temperatures may be established that permits detection of changes in heat exchanger performance by comparing and trending results from successive tests. A deviation of the measured temperature difference, from that predicted by the correlation for the measured cooling fluid inlet temperature, provides an indication of heat exchanger performance change.

\subsection{Pressure Loss Monitoring Method}

The objective of the pressure loss monitoring method is to monitor the pressure loss across a heat exchanger, corrected for flow conditions. The monitored fluid flow rate and pressure loss are measured to evaluate the heat exchanger thermal performance.

The pressure loss monitoring method may be used for heat exchangers:

a. If the design basis explicitly specifies the heat exchanger function or acceptance criteria in terms of a pressure loss, or

b. If the correlation between pressure loss and heat transfer is known, or

c. If the heat exchanger fouling characteristics are likely to create a flow restriction.

The pressure loss monitoring method may not be used for heat exchangers:

a. If the heat exchanger fouling layer thickness is so small as to preclude pressure loss from providing a reliable indication of heat exchanger capability, or

b. If the fluid being monitored is a liquid on the shell side of a heat exchanger, or

c. If the heat exchanger operating margin is known to be generally small, or 
d. If the flow rate on the tube side traverses flow regimes (i.e., phase change) in going from the test flow rate to the acceptance criteria flow rate.

Increases in pressure loss observed from trending can be used to detect the onset of flow blockage and, therefore, is an aid for determining inspection and/or cleaning frequencies. Even if heat loals are available, when fouling rates are high, pressure loss monitoring may provide a quick and simple way to monitor fouling without having to frequently perform heat transfer analysis.

\subsubsection{Additional Inspection and Testing Aging Management Methods}

The following four aging management methods can be used to effectively detect significant degradation and heat exchanger failure and should be implemented irrespective of thermal performance monitoring. Results from thermal performance monitoring/trending may precipitate implementation of these aging management methods.

- Visual Inspection Monitoring

- Leak Testing

- Eddy Current Testing

- Vibration Monitoring

\subsection{Visual Inspection Monitoring Method}

The objective of the visual inspection monitoring method is to determine the condition of the heat exchanger in relation to its ability to transfer heat. This method assumes that the heat exchanger being inspected will perform its intended function if it is maintained within a predetermined acceptably clean condition.

The visual inspection monitoring method may be used for heat exchangers:

a. If it is not possible to test or monitor heat exchanger performance by one of the previously described methods (Section 5.2.3.2), and

b. If there is sufficient access to inspect a representative sample of the surface on the heat exchanger side most likely to exhibit fouling, and

c. If the inspectors are fully qualified to identify and detect various types of fouling and can characterize the effects relative to heat exchanger degradation and/or performance deficiencies, and

d. If a predetermined acceptably clean condition exists to which the fouling can be compared.

The visual inspection monitoring method may not be used for heat exchangers:

a. If unacceptable fouling would not be readily detectable by visual inspection, or 
h. If the heat exchanger operating margin is known to be generally small.

The visual inspection monitoring method consists of visually inspecting the heat exchanger periodically, usually by disassembly, allowing access to the internals of the shell and tube sides. Corrective action or additional inspections can be implemented based on the inspection results. The inspection interval can be adjusted, based on experience.

General functions of a heat exchanger inspection program should include, but not limited to, the following:

- Sampling and identifying deposits present in both the channel head/waterbox and the tubes.

- Identifying the presence of biological growth.

- Detection and classification of corrosion.

- Performing a tube boroscope/video probe inspection.

- Checking for loose parts, deformation, discoloration, evidence of leakage, erosion, and other forms of degradation.

- Identifying the scope and details of coating activities, if performed.

- Undersianding water chemistry.

- Verifying tube sheet drawings and tube plugging activities.

- Documenting a report on the inspection activities.

\section{Heat Exchanger Tube Side Inspections}

Upon opening the heat exchanger, the amount and type of debris/sludge present in the endbells and tubes should be determined. The following actions should be taken with respect to debris/sludge found in the heat exchanger.

- Classify the debris/sludge type found in the heat exchanger tubes, i.e., mud, slime, sand, cooling tower fill, twigs, leaves, etc.

- Note the location of any debris/sludge that could possibly inhibit flow.

- Remove the upper layers of sludge or other deposits and determine if microbiological activity is present.

- Perform microbiological analyses of sampled sludge, including tubercules. 
- If tuberculation is occurring, tubercules should be excavated to determine depth of pitting.

Once the waterbox, tube sheet, tube ends, and endbells have been cleaned of loose debris, further inspection should be performed to characterize the extent of degradation. If the tube inside diameter is not known, measurements should be taken at the rolled portion of the tube for use in tube plugging operation. Existing tube plugs should be all accounted for and examined for signs of loosening and degradation.

Heat exchanger structural integrity should be verified. Wall thinning due to erosion and/or erosion/corrosion should be identified. The following areas should be examined and repaired as necessary:

- Welds of pass partitions to channel barrels and tube sheets.

- Parent metals of pass partitions, barrels, and tube sheets adjacent to welds.

- Nozzle weld cover passes.

- Parent metal of nozzles and channels in the region of penetration.

- Baffles, tube supports, tie rods, floating head, and other internal components.

- Gasket surfaces.

- Pressure boundary fasteners.

The tubes should be examined for cleanliness and corrosion products. Pitting should be identified and the extent of degradation characterized to the maximum extent possible. A representative sampling of deposits should be removed and analyzed to determine the most effective treatment/removal process. Once the tubes have been thoroughly cleaned, further inspection should be performed using a baroscope or other fiberoptics equipment to verify that the cleaning was satisfactorily accomplished. For general inspection of tubes and tube sheets, the following items should be checked for any applicable corrective actions:

- Inside diameter pitting and the extent of degradation.

- Tube ends for splits, etched surfaces, thinning, gnarled ends, and excessive tube projection.

- Tube-to-tube sheet welds for corrosion.

- Tube sheet ligaments for cracks, deformation, discoloration due to dealloying, and tubercule formation or staining around the tube joints. 
If hydrostatic testing is performed from the shell side, tube leaks are identified by noting water drips from the leaking tubes. For a direct confirmation, a magnifying boroscope or a video probe can be used from inside the leaking tube to confirm and identify the nature of tube leak.

\section{Heat Exchanger Shell Side Inspections}

Shell side inspections are practical to perform if eddy current testing indicates shell side fouling degradation or heat transfer performance monitoring indicates excessive fouling. Since fixed tube sheet bundles cannot be disassembled from their shell, it is ner sary to look into the bundle through each nozzle using either a video probe or fiberoptics to determine the extent of fouling, if any. If fouling is confirmed visually, scrape samples from nozzle walls and accessible tube surfaces for chemical analysis. Analysis of deposit composition should provide clues relative to the origination of the deposit and whether it is possible to chemically clean the shell side.

If shell side fouling cannot be verified visually, monitor how freely water flows through the shell side after performing the hydrostatic test. This is accomplished by connecting the shell to a circulating pump, flowmeter, and drum of water. By installing a pressure gauge at the inlet and outlet sides, the pressure drop can be measured. This measured value can then be compared with the nominal drop expected from a clean unit to determine the extent of fouling.

If the tube bundle is pulled out of the shell to allow for inspection of the shell interior and the bundle exterior, then the following areas should be examined and repaired when applicable:

- Inlet and outlet connections and their welds to the shell surface.

- Shell surfaces at the locations of the bundle baffles and support plates.

- Hole and tube surfaces where the tubes penetrate the baffles and tube support plates for corrosion.

- Tube surfaces for gradual thinning at baffle/tube support intersections.

- Rubbed tube surfaces or flat spots between baffles or tube support plates for vibrational damage.

- Tube-to-tube sheet interfaces for corrosion.

- Tie rods, spacers, sealing devices, and impingement plates to be sure that they are intact.

- Pressure boundary fasteners.

The shell interior should be sandblasted or hydroblasted before examining for corrosion. If worn spots on the shell surface are noted, then ultrasonic inspection to measure and quantify the remaining shell thickness should be performed. 


\subsection{Leak Testing Method}

Leak testing to find leaking tubes can be performed several ways depending on the design of the heat exchanger and the equipment available. The intent of leak testing is to locate a leak but not to quantify it. The following are a few examples of leak testing methods found to be effective in locating tube leaks.

The most simple is to perform a water leak test by filling the shell side of a heat exchanger with water and monitoring the tube ends for evidence of leakage. This can also be performed under pressure to further enhance its effectiveness. Air can also be used to pressurize the heat exchanger. Pressures on the order of $69 \mathrm{kPa}$ [10 psi] are usually sufficient. Be aware that failure of a vessel pressurized with air can be potentially dangerous, especially if it is of large volume.

Vacuum testing is usually limited to heat exchangers which cannot be pressurized due to their design. Air removal pumps can provide sufficient vacuum to detect fairly small tube leaks. The typical procedure is to create a vacuum on the shell side of the heat exchanger and use some means of detecting the air which will be drawn into the tube.

Whether pressurized or evacuated, the intent is to make a leak detection media flow from tube side to the shell side (or vice versa) of the heat exchanger. Once it is moving, a means must be used to detect its movement.

This can be done several ways with varying degrees of sensitivity using the following:

- Modern ultrasonic leak detectors are very useful and are capable of finding very small leaks. This is aided by the fact that the tube acts as a collimator for the sound originating from the leaking tube. They also have an advantage of examining a large number of tubes in a short time and will detect leaks under pressure as well as vacuum. It should be noted that a number of extraneous noises will be encountered during the leak detection test. Becoming familiar with what a leak sounds like and being able to distinguish spurious sounds from real leaks do require some skill and practice.

- Portable (hand held) tracer gas detectors. These instruments are sensitive to any gas stream having a thermal conductivity different from the ambient air in which the instrument is being used. The sensitivity of the equipment is mainly dependent on the ratio of the thermal conductivity of the leaking gas to ambient air. They also have the advantage that nearly any gas can be used as the leak detection media, i.e., helium, hydrogen, carbon dioxide, Freon R-12, sulfur-hexafluoride, etc.

- Another effective method of determining a tube leak is to plug one end of a tube with a rubber plug and attach a manometer to the opposite end. As the pressure increases or decreases, depending on whether a pressure or vacuum test is employed, small leaks will pressurize or evacuate the tube over time such that a leak is readily detectable. 
- Another approach for performing a leak test of an entire tube bundle is to attach a sheet of litmus paper to the face of the tube sheet and inject ammonia gas into the shell side of the heat exchanger. As the gas leaks to the tube side, a spot corresponding to the tube location will appear on the paper, thus providing a map of the leaking tubes. The ammonia gas should be used with caution especially for heat exchangers with admiralty brass tubing since ammonia is known to cause stress corrosion cracking of tubing.

- Another means of leak testing a tube bundle which cannot be evacuated or pressurized on the shell side due to design is to perform a tube side vacuum test. This involves the fabrication of a plexiglass manway cover equipped with fittings with which to fill the tube side of the heat exchanger with water while allowing the air to vent. Once the heat exchanger is full of water, a vacuum is drawn using the same fitting, while closing the air vent. The vacuum will result in leaking tubes drawing air through the leak from the shell side. This is evidenced by bubbles exiting from the leaking tube as viewed from the plexiglass manway.

These examples are only a few of many ways to leak test a heat exchanger but they all share the basic concept of leak detection, forcing of leak detection media to travel from one side of a barrier to another while employing some means to detect the movement.

\subsection{Eddy Current Testing Method}

Eddy current testing is a non-destructive examination method that identifies and characterizes flaws present in thin-walled heat exchanger tubing. It is applicable to nonferromagnetic, thin-wall metal tubing from approximately $6.35 \mathrm{~mm}[0.25 \mathrm{in}]$ to approximately $50.8 \mathrm{~mm}$ [2.0 in] outside diameter. The eddy current testing method is generally limited to applications where heat exchanger tube material thickness does not exceed $3.17 \mathrm{~mm}[0.125 \mathrm{in}]$.

When a changing magnetic field is brought into the vicinity of a conductive heat exchanger tube, a voltage and electrical cur:ent (i.e., eddy current) is induced in the tube material through an electromagnetic induction. Eddy currents travel in closed loops which are perpendicular to the direction of the flux. In heat exchanger tubes, the eddy currents travel around the circumference of the tube. Therefore, it is more difficult to detect circumferential tube cracking than other crack orientations (e.g., along the length of the tube).

The depth of penetration of the magnetic field and presence of eddy currents is a function of the test frequency, tube material electrical conductivity, and tube material magnetic permeability. The test frequency is the most critical parameter because the tube material parameters are, in the majority of cases, known values. Operating at too high a frequency will cause the eddy currents to concentrate at the inside surface of the tube. Conversely, operating at too low a frequency will result in no tube wall examination but just the examination of tube external artifacts such as deposits and support structures.

The depth at which eddy current density has decayed to approximately $37 \%$ of the surface density is called the standard depth of penetration. One standard depth of penetration is used as 
a guide to select the optimum operating frequency for a given tube material and thickness. This will ensure adequate coverage and detection of heat exchanger tube flaws.

Eddy current is an indirect testing method requiring the use of a calibration standard to review and analyze the relative condition of the inspected tubing. The calibration standard is a tube sample identical to the tube being tested (e.g., material, diameter, thickness, fin design, etc.) with known flaws machined into the surface.

Two methods of evaluating eddy current data are phase analysis and amplitude analysis. Amplitude analysis uses one dimension of the eddy current output to measure the depth of an indication. Amplitude analysis is fast and efficient, and has an acceptable level of accuracy when tube flaw characteristics are known based on prior knowledge and experience. If the tube damage forms are not known, phase angle analysis is preferred. Phase angle analysis uses a two dimensional eddy current coil response which is a somewhat more accurate analysis method.

\subsection{Vibration Monitoring Method}

This section (i.e., 5.2.3.3.4) provides a simplistic and highly condensed version of the information contained in ASME OM Part 11 (i.e., Reference 5.8). The user of this AMG is cautioned to follow the requirements of ASME OM Part 11 as opposed to that which is presented in this section. This section is ONLY meant to give the reader a very broad overview of ASME OM Part 11 and is NOT considered and shall NOT be used as the authority for heat exchanger vibration monitoring. That authority resides with ASME OM Part 11.

Heat exchanger tube vibration is caused by shell side cross-flow which represents a source of energy that can excite and sustain vibration. There are three types of heat exchanger vibration measurement methods. In order of increasing complexity and application cost, the methods are as follows:

a. External Monitoring for Impacting. With this method, accelerometers are mounted on the exterior surfaces of the heat exchanger. As impacts (from tube-to-tube, tubeto-tube support, etc.) occur on the inside of the heat exchanger, vibration signals are generated by the accelerometers and the signals are recorded.

The benefits of this method are:

- Severe tube vibration can be detected.

- In some cases, the general location of impacting may be indicated.

- Identify the threshold shell side flow rate where impacting occurs or determine that impacting does not occur up to an established flow rate limit.

- Provide criterion to determine the need for additional, more detailed tests or structural modifications.

The limitations of this method are: 
- Particular tubes that are impacting cannot be readily identified.

- The onset of impacting and determination of corresponding flow rate may not be adequately detectable.

b. Microphone Scan to Detect Impacting. With this method, microphones are installed at the tube ends. As impacts occur, the microphones will detect the noise and provide a signal that is monitored.

The benefits of this method are:

- Identify the number and specific location of tubes that are impacting (i.e., vibrating).

- In some cases, provide an approximate indication of the relative severity of impacting associated with various tubes.

- Provide a basis for establishing an acceptable shell side operating flow rate limit to preclude vibration impacting.

- Provide the basis to determine the need for additional, more detailed direct measurements or other remedial actions.

The limitations of this method are:

- The tube sheet must be accessible during heat exchanger testing.

c. Direct Measurement of Tube Response. With this method, transducers are mounted on or adjacent to individual heat exchanger tubes. This method can provide vibration response amplitude and frequency information for specific tubes. This method provides the best data for assessing the potential for vibration-induced heat exchanger tube degradation from wear and fatigue.

The limitation of this method is that replacement of failed transducers and instrumentation is difficult and impractical for some configurations.

In general, heat exchanger tubes will vibrate at all flow rates. However, it is the largeamplitude motion associated with fluid elastic instability that is of most concern. This large motion has the potential to lead to early failure of the equipment. The small-amplitude motion associated with subcritical flow rates is generally acceptable. However, there are situations in which vortex shedding or high turbulence levels in combination with adverse or inadequate support conditions or support deterioration can cause unacceptable tube vibration.

Tube vibrational characteristics are determined by baffle spacing, tube-to-baffle-hole clearance, baffle plate alignment, tube straightness, mechanical fit-up of the tubes and tube axial loads, tube pattern and pitch, and the properties of the shell side fluid. 


\subsubsection{Microbiologically Influenced Corrosion (MIC) Control Program}

Proper diagnosis is particularly important in situations where MIC is suspected since treatment can be expensive in terms of time, equipment, materials, and environmental impact. Background information such as materials of construction, fabrication methods, and operating history can yield significant insights into potential microbiological influences. Examples of operating history are: source of water, types of water treatment, lay-up methods, and operating characteristics (i.e., stagnation, low flow, intermittent operation and operating time).

\subsubsection{Water Sampling}

Sampling of the water at the source and immediately upstream and downstream from the heat exchanger during quarterly testing is sufficient to assess seasonal variations in microbial content, oxygen, and critical nutrients. A complete water analysis will assist in separating corrosive affects of the water from microbial influence. Sampling of the water at these locations is useful to (1) identify heavily infested areas requiring further investigation, (2) evaluate the effectiveness of biocide treatments, (3) locate areas where microbes may be reproducing rapidly, and (4) detect trends over time to focus sampling.

\subsubsection{Solid Sampling}

When the heat exchanger is opened up for maintenance purposes, areas of interest should be visually examined and solid samples removed for detailed chemical and microbiological examination. Typically, deposits, tubercules, or volumes of corrosion products in the vicinity of the corrosion site are the areas where the samples should be removed for analysis. Additional visual examination of the under deposit area and removal of metal samples for metallurgical analysis may be appropriate. MIC leaves a particular set of chemical fingerprints that can be used to determine whether or not MIC is at work. When a sample exhibits very low organic content and, essentially no enrichment in sulfur or chloride is noted (as compared to the base metal and/or water analysis), MIC is not likely to have been a contributor to the corrosion.

\subsubsection{Treatment}

Treatments to control MIC fall into three general categories: mechanical cleaning, chemical treatment, and engineering and operational controls [5.11].

\section{Mechanical Cleaning}

Mechanical methods are used to physically remove deposits from material surfaces. In this way, impediments to flow are also removed. Since MIC is always associated with biofilms on metal surfaces the first objective is to remove the film. In some cases, these biofilms are extremely difficult to remove with biocides or corrosion inhibitors, as such, mechanical cleaning methods must be applied. When the heat exchanger is opened up for maintenance purposes and after the solid samples have been removed, hydrolyzing and/or steam lancing can be performed to remove deposits and tubercules. Abrasive particles (i.e., sandblasting) can also be used on the heat exchanger shell surfaces; however, a disadvantage with this method is the collection and cleanup of the material. 


\section{Chemical Treatment}

Chemical water treatments include the use of biocides, corrosion inhibitors, and dispersant. Biocides may be oxidizing or non-oxidizing agents with injection to the fluid stream made on a continuous base or scheduled as a batch/slug process. Biocides can be used in combination with one another to increase their effectiveness, decrease effluent concentrations, or reduce costs. Biocides may also be used in conjunction with dispersant to prevent accumulation of deposits. Inhibitors may be used independently or along with biocides or dispersant for corrosion control.

Oxidizing biocides, particularly chlorine, are by far the most commonly utilized agent for MIC control. Economics, simplicity of use, and the vast experience base are the overriding considerations for the utilization of chlorine. Depending on water and solid sample analysis results, other oxidizing biocides such as chlorine dioxide, bromine compounds, ozone, and/or hydrogen peroxide may be used. Non-oxidizing biocides which may be used are acrolein, glutaraldehyde, isothiazoline, and quartenary ammonia compounds.

Used in conjunction with biocides, dispersants help to remove organisms killed by the biocidal treatment along with nutrients and debris that may have become attached to the biofilm. Dispersant keep such materials suspended in the fluid stream.

Corrosion inhibitors, such as chromates, have biocidal properties and can be effective in the treatment of MIC provided the biological growth has been removed from the heat exchanger surfaces either mechanically or chemically and the microbial infestation has been controlled. Corrosion inhibitors are used primarily in Closed Cooling Water Systems.

\section{Engineering and Operational Controls}

Engineering and operational controls may involve draining and drying heat exchangers during outages, elimination of stagnation by periodic operation of the heat exchangers or periodic flushing with high velocity fluid. Engineering controls may also include implementation of modifications or thermal treatment with high temperature.

For carbon steels and copper alloys, where sulfate reducing hacteria activity is high, intermittent flow provides cyclic oxidation and can produce the worst case corrosion situation. For stainless steels, intermittent flow conditions are preferable to stagnation, because the attachment of bacteria to heat exchanger surfaces is minimized thereby reducing the effects of MIC.

It may be possible in some heat exchanger applications to design and install sacrificial anodes to cathodically protect the heat exchanger subcomponents from MIC and other corrosion forms. The size and location of the sacrificial anode, and the anode material must be selected in such a way that the protective current density on any focation is larger than the corrosion current density. Common shapes of sacrificial anodes include bars, plates, cylinders, and ribhons. Most of the anodes for application in water are cast with a galvanized steel core, wire, or strap to facilitate welding or bolting. 


\subsection{Non-Conventional Effective Programs Commonly Used in the Industry}

This section is a discussion of some of the less common maintenance and surveillance programs determined from aging studies to be effective in detecting manifestation of aging mechanisms and mitigating the degradation of heat exchangers within acceptable limits.

\subsubsection{Heat Exchanger Lay-Up Program}

Lay-up practices have historically been applied on a random basis. Development of a layup program provides organization to these lay-up practices and a comprehensive structure for their implementation. Systems and component level lay-up activities should be scheduled and performed so that station personnel are effectively utilized. Rigorous implementation of plant lay-up procedures will result in enhanced equipment preservation, personnel dose reduction, improved water chemistry, and quicker plant start-up and power ascension.

Condition assessments provide the basis for a plant lay-up program and should be utilized to monitor effectiveness of the lay-up methods. In addition to refining lay-up procedures, condition assessment will ensure that component performance and functional requirements are met during plant operation.

Practical and convenient lay-up methods for these heat exchangers and their associated systems should address several criteria. It must be practical to continuously circulate the lay-up fluid. Where dry lay-up is used, it must be practical to purge the fluid from the system in a reasonable amount of time, and the volume of fluid must be stored or processed. The lay-up practices should be flexible so that maintenance access can be readily achieved. Existing access openings should be used to the maximum extent possible. The appropriate lay-up method should be fast and easy to implement.

There are several different types of lay-up methods that can be used. The length of outage time and scheduled maintenance activities to be performed on the particular heat exchanger and/or associated system will dictate the most appropriate and cost-effective lay-up method to be implemented.

\subsubsection{Dry Lay-Up Method}

The dry lay-up method is the most flexible approach for accommodating maintenance during outages, because the lay-up fluid (i.e., air) is not hazardous. The heat exchanger and/or associated system should be rapidly drained and purged with air such that internal surfaces are dry and the atmosphere is well below saturation. Recent advances in desiccant air dryer technoiogy have increased the attractiveness of this method by lowering the cost of high volume dry air.

\subsubsection{Wet Lay-Up Method}

To implement wet lay-up, the heat exchanger and/or associated system is completely filled with water or filled with water and an overpressure of nitrogen. Normally, some method of water circulation is used to facilitate homogeneous mixing of chemicals used to treat the water. 
In some applications, hydrazine, which is an oxygen scavenger, may be used to treat the water. Higher than normal concentration of chlorine may be maintained in raw water systems. Corrosion inhibitors, such as chromates in Closed Cooling Water Systems, can be considered a form of wet lay-up. Any chemical addition for the purpose of corrosion control in wet lay-up must be approved by plant Chemistry Department personnel.

\subsubsection{Nitrogen Lay-Up Methods}

The nitrogen lay-up method entails draining the heat exchanger and/or associated system, connecting a nitrogen supply, and purging the space with a volume of $\mathrm{N}_{2}$ approximately four times the region volume. After filling, the heat exchanger andior system is isolated and the nitrogen supply regulators are set to maintain a slightly positive pressure.

It is extremely important to note that a nitrogen environment can result in asphyxiation. Therefore, adequate safety precautions are necessary to prevent personnel access into lay-up regions where nitrogen accumulation could occur until adequate ventilation has been provided. Periodic checks for oxygen deficiency should be performed in these areas prior to entry.

\subsubsection{4 "No Treatment" Lay-Up Methods - Drained and "As-Is"}

In the drained lay-up condition, the heat exchanger is allowed to drain. For this method, the volume of drained water must be stored or processed. Subsequent to draining, the equipment is exposed to moisture laden air and/or water in contact with air. Under this environment, corrosion of unprotected carbon steel can be quite severe. However, it should be noted that many of the surfaces in PWRs will be covered with a magnetite film formed under the reducing conditions associated with normal operating chemistries. In BWRs, a hematite film is formed on the surfaces. Some level of general surface corrosion protection is expected from these surface films for several weeks or longer.

In the "As-Is" lay-up condition, the heat exchanger and/or associated system remains without any special treatment after being isolated. For sysiem heat exchangers that normally process deoxygenated primary coolant they will remain moderately non-corrosive as long as the heat exchanger and/or system is kept isolated. For carbon steel system heat exchangers that normally process raw water or demineralized water containing a high oxygen content, the corrosion process will proceed at a decreasing rate provided a fresh source of oxygen is not allowed ingress to the system (i.e., the system remains isolated). This is because as the corrosion process progresses, the oxygen reacts with the carbon steel to form iron oxide which results in less oxygen available to continue the corrosion process.

\subsubsection{Operator Activities}

Operators routinely tour the plant (i.e., operator walkdown) to observe heat exchanger conditions and record results on a checklist that contains qualitative and quantitative acceptance criteria. Individual checklist items are performed at various frequencies ranging from hourly to monthly. The frequency is established based on experienced rates of change or degradation potential for the observed item. If acceptance criteria is not met, the operators inform the shift supervisor who initiates corrective or investigative action. 
Another operator action is the annunciator response procedure (ARP). These procedures prescribe the actions that operators must take in response to individual automatic alarms. When degradation causes a change in system or component operating parameters, and that parameter is monitored by an automatic alarm, the operator will take specific actions in response. If the operator cannot correct the alarming condition (as in a degraded state), then the operator reports the condition to the shift supervisor who initiates corrective or investigative actions. For most normally operating heat exchangers, the heat exchanger alarms before the limiting criteria is exceeded, to allow time to evaluate, correct, or transfer to a standby heat exchanger without impacting plant operations.

\subsubsection{Coatings Survey Program}

This program maintains protective coatings on plant equipment including heat exchangers. Periodic walkdowns of the heat exchangers ensures that visible degradation will be detected prior to significant damage occurring to the heat exchanger. This program aids in maintaining the exterior surfaces of the heat exchangers to reduce the potential for undetected age-related degradation. Only approved coatings for each application may be used and are specified in the program. Surface cleaning and preparation are also specified in program documents.

\subsubsection{Operating/Industry Experience Program}

The operating experience program tracks problems identified by in-house and external industry heat exchanger operating experience and initiates corrective actions or evaluations to mitigate the problems.

This program supports the other heat exchanger aging management programs by providing feedback on heat exchanger failures or degradation. This program can capture 10 CFR Part 21 notices; NRC Bulletins, Notices, and Generic Letters; vendor experiences; INPO Reports; Significant Operating Event Reports (SOERs); etc.; involving heat exchangers, and ensure all known potential problems are addressed at the plant before failure occurs.

\subsubsection{Spare Parts Shelf-Life Program}

An important program to all plants is the spare parts/shelf life program. This program is typically set up on a computer database with maximum and minimum quantities assigned to each part. Parts are automatically reordered when the stock available drops below the minimum quantities specified. Gaskets and other heat exchanger parts with a prescribed shelf life are controlled to ensure parts which have exceeded their shelf life are not installed in heat exchangers or to ensure an engineering evaluation is performed or a part which exceeds its shelf life. Spare parts are stored in a controlled atmosphere to ensure they are maintained in excellent condition. All of these activities ensure that heat exchangers are repaired and maintained properly and ensure that replacement parts do not cause abnormal degradation to occur to the inservice heat exchanger. 


\subsubsection{Recelpt Inspection}

10 CFR 50, Appendix B requires control of purchased material, equipment, and services. This requirement is typically performed by a receipt inspection program.

The receipt inspection program provides a baseline for critical dimensions, material type, and various other attributes important to a heat exchanger. Proper inspection and detection of flaws, defects, cracks, and other discrepancies ensures that heat exchanger components are in excellent condition prior to installation and that the heat exchanger can be expected to provide acceptable service for its service life.

Documentation required by receipt inspection procedures for heal exchanger components is beneficial in that the material properties are accurately defined. The receipt inspection program also verifies proper documentation is received with the components which proves to be beneficial in assuring effective management of aging. These activities are important to ensure that the heat exchanger components in storage will be in excellent condition prior to being placed in service.

\subsection{Programs/Techniques Applied to Heat Exchangers}

This section assesses and evaluates the effectiveness of the various programs/techniques described in Sections 5.2 and 5.3 with respect to their capability for detection and/or mitigation of the significant aging mechanisms identified in Section 4.3 and summarized in Tables 4-3 through 4-8.

The irequencies of conducting these programs/techniques are based on current codes and standards as well as industry practice. The failure data conclusions presented in Section 3.6 suggest that current industry practices should be enhanced to detect and mitigate aging of heat exchangers (see Sections 5.2.2 and 5.2.3). Other conclusions, also drawn from the failure data, which were considered in selecting the program/technique implementing intervals are:

- Since many of the heal exchangers within the scope of this AMG are in continuous operation, shorter rather than longer implementing intervals are appropriate.

- Since the heat exchanger tubes and coils, shell, internals and nozzles, tube sheet, and waterbox dominate the NPRDS and LER failure data, actions to detect aging of these heat exchanger components should be implemented on a shorter rather than longer implementing interval.

- Since the primary aging mechanisms for heat exchanger tubes and coils, shell, internals, and nozzles, tube sheet, and waterbox are fouling, corrosion, erosion/ corrosion, and wear, the programs/techniques implemented more frequently should concentrate on detecting these aging mechanisms.

Section 5.4.1 will correspond to the system heat exchangers and significant aging mechanisms depicted on Table 4-3, Sections 5.4.2 through 5.4.6 will correspond to Tables 4-4 through $4-8$ respectively. 


\subsubsection{Primary Water System Heat Exchangers}

From Tables 3-5 and 3-6 (i.e., tube side and shell side fluids) the primary water system heat exchangers discussed in this section are the (1) BWR RWCU System regenerative and nonregenerative heat exchangers and the HPCI System gland seal condenser and (2) PWR CVCS regenerative, letdown, excess letdown and seal water heat exchangers and the RHR heat exchangers. These heat exchangers were evaluated by subcomponent and the associated aging mechanisms, determined in Section 4.3, to be significant are:

- Tubes

- Mechanical Fatigue

- Intergranular Stress Corrosion Cracking

- Wear

- Fouling

- Tube Sheets

- Mechanical Fatigue

- Intergranular Stress Corrosion Cracking

- Wear

- Fouling

- Shell/Nozzles/Internals

- Mechanical Fatigue

- Intergranular Stress Corrosion Cracking

- Erosion and Erosion/Corrosion

- Fouling

- Waterbox/Channel Head/Divider Plate

- Mechanical Fatigue

- Intergranular Stress Corrosion Cracking

- Fouling

- Pressure Boundary Fasteners/Support Assembly

- Stress Relaxation

- General Corrosion

The following programs/techniques are considered effective for detection and mitigation of these aging mechanisms.

- Mechanical Fatigue

- ASME Section XI Inservice Inspection and Testing 
- Preventive Maintenance

- ASME Operation and Maintenance Code

- Intergranular Stress Corrosion Cracking

- ASME Section XI Inservice Inspection and Testing

- Preventive Maintenance

- ASME Operation and Maintenance Code

- Wear

- Preventive Maintenance

- ASME Operation and Maintenance Code

- Fouling

- Preventive Maintenance

- ASME Operation and Maintenance Code

- Erosion and Erosion/Corrosion

- No Programs are Required (see Section 5.4.1.5)

- Stress Relaxation

- ASME Section XI Inservice Inspection and Testing

- Preventive Maintenanc:

- General Corrosion

- ASME Section XI Inservice Inspection and Testing

- Preventive Maintenance

Table 5-2 summarizes the results and conclusions associated with the following effective program/technique evaluations.

\subsubsection{Mechanical Fatigue}

Detecting the presence of mechanical fatigue in the primary water system heat exchanger subcomponents is virtually impossible to achieve until such time as the subcomponent begins to exhibit abnormal behavior. Therefore, programs/techniques to effectively manage mechanical fatigue are generally performance based. Through heat exchanger performance monitoring and data acquisition, the trending of key operational parameters may provide sufficient information, prior to hcat exchanger failure, so that planned maintenance activities can be conducted to repair/replace the affected heat exchanger subcomponent(s). Visual inspections and eddy current examinations are also helpful for fatigue detection in some situations. A combination of programs/techniques must be implemented to effectively manage mechanical fatigue of (1) BWR 
AGING MANAGEMENT GUIDELINE FOR HEAT EXCHANGERS

\begin{tabular}{|c|c|c|c|c|c|c|c|}
\hline \multirow[b]{2}{*}{$\begin{array}{l}\text { Heat Exchanger } \\
\text { Subcomponent }\end{array}$} & \multicolumn{4}{|c|}{ Conventional Programs/Techniques Commonly Used } & \multicolumn{3}{|c|}{ Non-Conventional Programs/Techniques Commonly Used } \\
\hline & $\begin{array}{l}\text { ASME Sect. XI, } \\
\text { ISI. and IST }\end{array}$ & $\begin{array}{l}\text { ASME Operations and } \\
\text { Maintenance Standards }\end{array}$ & $\begin{array}{l}\text { Preventive } \\
\text { Maintenance }\end{array}$ & $\begin{array}{c}\text { MIC } \\
\text { Control }\end{array}$ & Lay-up & Operator Activities & Coatings Survey \\
\hline Tubes/Coils & & $\begin{array}{l}\text { Thermal Performance } \\
\text { Leak Testing } \\
\text { Eddy Current } \\
\text { Vibration Monitonng }\end{array}$ & $\begin{array}{l}\text { Thermal Performance } \\
\text { Leak Testing } \\
\text { Eddy Current } \\
\text { Vibration Monitoring }\end{array}$ & & Preservation & & \\
\hline Tube Sheet & & $\begin{array}{l}\text { Visual Inspection } \\
\text { Thermal Performance } \\
\text { Leak Testing }\end{array}$ & $\begin{array}{l}\text { Visual Inspection } \\
\text { Thermal Performance } \\
\text { Leak Testing }\end{array}$ & & Preservation & & \\
\hline $\begin{array}{l}\text { Shell/Nozzles/ } \\
\text { Internals }\end{array}$ & $\begin{array}{l}\text { Volumetric Examination } \\
\text { Surface Examination } \\
\text { Visual Examination } \\
\text { Pressure Testing }\end{array}$ & $\begin{array}{l}\text { Visual Inspection } \\
\text { Vibration Monitoring }\end{array}$ & $\begin{array}{l}\text { Visual Inspection } \\
\text { Vibration Monitoring }\end{array}$ & & Preservation & Inspections & Inspections \\
\hline $\begin{array}{l}\text { Waterbox/ } \\
\text { Channel Head/ } \\
\text { Divider Plate }\end{array}$ & $\begin{array}{l}\text { Volumetric Examination } \\
\text { Surface Examination } \\
\text { Visual Examination } \\
\text { Pressure Testing }\end{array}$ & $\begin{array}{l}\text { Visual Inspection } \\
\text { Thermal Performance }\end{array}$ & $\begin{array}{l}\text { Visual Inspection } \\
\text { Thermal Performance }\end{array}$ & & Preservation & Inspections & Inspections \\
\hline $\begin{array}{l}\text { Pressure Boundary } \\
\text { Fasteners/Support } \\
\text { Assembly }\end{array}$ & $\begin{array}{l}\text { Volumetric Examination } \\
\text { Pressure Testing }\end{array}$ & & $\begin{array}{l}\text { Torque Requirement } \\
\text { Coating Protection }\end{array}$ & & Preservation & Inspections & Inspections \\
\hline
\end{tabular}


plant RWCU regenerative and non-regenerative heat exchangers and HPCI gland seal condensers, and (2) PWR plant CVC regenerative, letdown, excess letdown, and seal water heat exchangers and RHR heat exchangers.

For stainless steel heat exchanger tubes in primary water applications some form of vibration monitoring should be performed in accordance with either the plant's Preventive Maintenance Program or ASME Operation and Maintenance Code Program, whichever applies. Vibration monitoring is the most effective method to detect significant degradation and heat exchanger tube failure due to flow induced cyclic loading and mechanical fatigue. Permanently installed vibration monitoring equipment would be the optimum; however, this is not a requirement to acquire the necessary data for analysis. Section 5.2.3.3.4 describes three types of heat exchanger vibration measurement methods. Vibration monitoring should be performed on each primary water heat exchanger once per operating cycle and after major heat exchanger maintenance that changes the baseline vibration levels.

Eddy current examination methods performed in accordance with either the plant's Preventive Maintenance Program or ASME Operation and Maintenance Code Program, whichever applies, will identify and characterize flaws in non-ferromagnetic heat exchanger tubes. If the number or magnitude of cyclic loads experienced produces fatigue flaws (i.e., fretting) in the tubes, then eddy current testing is effective at detecting these flaws. It is not necessary for these flaws to propagate through the tube wall for eddy current testing to be effective. Eddy current testing (see Section 5.2.3.3.3) should be performed on each primary water heat exchanger at least once each 10-year inspection interval and whenever the heat exchanger is open for maintenance activities.

If the number or magnitude of cyclic loading causes the heat exchanger tube to fail from mechanical fatigue, such that through wall cracking occurs, then thermal performance monitoring and leak testing will effectively detect the tube failures. Thermal performance monitoring and leak testing of heat exchangers is performed in accordance with either the plants Preventive Maintenance or ASME Operation and Maintenance Code Program whichever applies. Most heat exchangers are designed with heat transfer capacity margin such that a percentage of tubes can be plugged without impacting the ability of the heat exchanger to satisfy its required function. The thermal performance characteristics of the heat exchanger, however, decreases as the number of tubes that are plugged increases. Section 5.2.3.2 describes several thermal performance monitoring methods, and Section 5.2.3.3.2 describes several leak testing methods that can be used to detect failed heat exchanger tubes. Thermal performance monitoring should be performed on each primary water heat exchanger in accordance with the requirements of Reference 5.9, not to exceed 10 years. Leak testing should be performed on these heat exchangers whenever tube leaks are suspected.

Therefore, if vibration data and thermal performance data are obtained and trended on the primary water heat exchangers once per operating cycle (or other frequency determined to be adequate by plant specific operating history) and following major maintenance activities; and eddy current testing and leak testing is performed to identify degraded and leaky tubes, then mechanical fatigue of the heat exchanger tubes is effectively managed. 
For a stainless steel heat exchanger tube sheet in a primary water application, visual inspection should be performed in accordance with the plant's Preventive Maintenance Program or ASME Operation and Maintenance Code Program whichever applies. Visual inspection (see Section 5.2.3.3.1) is the most effective method to detect significant degradation and heat exchanger tube sheet failure due to cyclic loading and mechanical fatigue. Visual inspection should be performed on each primary water heat exchanger once per 10-year inspection interval. From Section 4.3.2.2.2 in most instances, fatigue cracking occurs in the tube sheet ligaments (i.e., space between the holes). If ligament cracking propagates far enough, leakage across the tube sheet can be detected by thermal performance monitoring and leak testing methods as described in Sections 5.2.3.2 and 5.2.3.3.2 respectively. Thermal performance monitoring should be performed on each primary water heat exchanger in accordance with the requirements of Reference 5.9, not to exceed 10 years. Leak testing should be performed on these heat exchangers whenever tube sheet leaks are suspected.

Therefore, if visual inspection is performed once per 10-year inspection interval, thermal performance data is obtained and trended once per operating cycle (or other frequency determined to be adequate by plant specific operating history), and leak testing is performed to identify leaky tube sheet areas, then mechanical fatigue of the heat exchanger tube sheet is effectively managed.

For a stainless steel heat exchanger shell, waterbox/channel head, and nozzles in a primary water application, volumetric, surface, and visual examinations and pressure testing should be performed in accordance with the plant's ASME Section XI, Inservice Inspection and Testing Program. The required examinations for Class 2 heat exchangers (see Section 5.2.1.1) should be followed for these primary water heat exchanger applications. These shell, waterbox/channel head and nozzle examinations are performed each 10-year inspection interval. The pressure tests are performed at least once each inspection period at a test pressure equal to the nominal operating pressure during system operation. Either a hydrostatic pressure test or the requirements of ASME Code Case N-498 is performed at or near the end of each 10-year inspection interval. The heat exchanger shell, waterbox/ channel head, and exterior surfaces nozzle are visually examined for evidence of leakage during these pressure tests. Corrective action are implemented in accordance with the rules and requirements of ASME Section XI (see Section 5.2.1.3).

Therefore, if volumetric, surface, and visual examinations are performed on the heat exchanger shell, waterbox/channel head, and nozzles each 10-year inspection interval and pressure testing is performed at least once each inspection period, then mechanical fatigue of the primary water heat exchanger shell, waterbox/channel head, and nozzles is effectively managed.

For stainless steel heat exchanger shell side internals, visual inspections should be performed in accordance with the plant's Preventive Maintenance Program or ASME Operation and Maintenance Code Program, whichever applies. Visual inspection (see Section 5.2.3.3.1) is the most effective method to detect significant degradation and failure of the heat exchanger shell side internals due to cyclic loading and mechanical fatigue. Visual inspection should be performed on each primary water heat exchanger once per 10-year inspection interval.

If mechanical fatigue causes the heat exchanger internals to become loose, then it is likely that vibration levels will increase. Vibration monitoring should be performed in accordance with either the plant's Preventive Maintenance Program or ASME Operation, and Maintenance Code 
Program, whichever applies. Permanently installed vibration monitoring equipment would be the optimum, however, this is not a requirement to acquire the necessary data for analysis. Vibration monitoring should be performed on each primary water heat exchanger once per operating cycle and after major maintenance that changes the baseline vibration levels.

Therefore, if visual inspection is performed once per 10-year inspection interval and vibration data are obtained and trended on the primary water heat exchangers once per operating cycle (or other frequency determined to be adequate by plant specific operating history) and following major maintenance activities, then mechanical fatigue of the heat exchanger internals is effectively managed.

For a stainless steel heat exchanger tube side divider plate, visual inspections should be performed in accordance with the plant's Preventive Maintenance Program or ASME Operation and Maintenance Code Program, whichever applies. Visual inspection (see Section 5.2.3.3.1) is the most effective method to detect significant degradation and failure of the heat exchanger tube side divider plate due to cyclic loading and mechanical fatigue. Visual inspection should be performed on each primary water heat exchanger once per 10-year inspection interval.

If mechanical fatigue causes the divider plate to become detached or otherwise broken such that cooling water flow bypasses the tubes then thermal capacity of the heat exchanger is diminished. Thermal performance monitoring should be performed in accordance with either the plant's Preventive Maintenance Program or ASME Operation and Maintenance Code Program, whichever applies. Section 5.2.3.2 describes several thermal performance monitoring methods that can be used to detect a failed heat exchanger divider plate. Thermal performance monitoring should be performed on each primary water heat exchanger in accordance with the requirements of Reference 5.9 , not to exceed 10 years.

Therefore, if visual inspection is performed once per 10-year inspection interval and thermal performance data is obtained and trended on the primary water heat exchangers once per operating cycle (or other frequency determined to be adequate by plant specific operating history), then mechanical fatigue of the heat exchanger tube side divider plate is effectively managed.

\subsubsection{Intergranular Stress Coriosion Cracking}

Detecting the presence of IGSCC in the primary water system heat exchanger subcomponents is virtually impossible to achieve until such time as the subcomponent begins to exhibit abnormal behavior. Therefoic, programs/techniques to effectively manage IGSCC are generally performance based. Through heat exchanger performance monitoring and data acquisition, the trending of key operational parameters may provide sufficient information, prior to heat exchanger failure, so that planned maintenance activities can be conducted to repair/replace the affecied heat exchanger subcomponent(s). Visual inspection and eddy current examinations are also helpful for IGSCC detection in some situations. A combination of program/techniques must be implemented to effectively manage IGSCC of (1) BWR plant RWCU regenerative heat exchangers and (2) PWR plant CVC regenerative, letdown, excess letdown, and seal water heat exchangers and the RHR heat exchangers. 


\section{AGING MANAGEMENT GUIDELINE FOR HEAT EXCHANGERS}

Eddy current examination methods performed in accordance with either the plant's Preventive Maintenance Program or ASME Operation and Maintenance Code Program, whichever applies, will identify and characterize flaws in non-ferromagnetic heat exchanger tubes. If IGSCC produces flaws (i.e., cracking) in the tubes, then eddy current testing is effective at detecting these flaws. It is not necessary for these flaws to propagate through the tube wall for eddy current testing to be effective. Eddy current testing (see Section 5.2.3.3.3) should be performed on each primary water heat exchanger at least once each 10-year inspection interval and whenever the heat exchanger is open for maintenance activities.

If IGSCC causes the heat exchanger tube to fail such that through wall cracking occurs, then thermal performance monitoring and leak testing will effectively detect the tube failures. Thermal performance monitoring and leak testing of heat exchangers is performed in accordance with either the plant's Preventive Maintenance Program or ASME Operation and Maintenance Code Program, whichever applies. Most heat exchangers are designed with enough heat transfer capacity margin such that a percentage of tubes can be plugged without impacting the ability of the heat exchanger to satisfy its required function. The thermal performance characteristics of the heat exchanger, however, decreases as the number of tubes that are plugged increases. Section 5.2.3.2 describes several thermal performance monitoring methods and Section 5.2.3.3.2 describes several leak testing methods that can be used to detect failed heat exchanger tubes. Thermal performance monitoring should be performed on each primary water heat exchanger in accordance with the requirements of Reference 5.9, not to exceed 10 years. Leak testing should be performed on these heat exchangers whenever tube leaks are suspected.

Therefore, if thermal performance data is obtained and trended on the primary water heat exchangers once per operating cycle (or other frequency determined to be adequate by plant specific operating history), and eddy current testing and leak testing is performed to identify degraded and leaky tubes, then IGSCC of the heat exchanger tubes is effectively managed.

For a stainless steel heat exchanger tube sheet in a primary water application, visual inspection should be performed in accordance with the plant's Preventive Maintenance Program or ASME Operation and Maintenance Code Program, whichever applies. Visual inspection (see Section 5.2.3.3.1) is the most effective method to detect significant degradation and heat exchanger tube sheet failure due to IGSCC. Visual inspection should be performed on each primary water heat exchanger once per 10-year inspection interval. If cracking propagates far enough, leakage across the tube sheet can be detected by thermal performance monitoring and leak testing methods as described in Sections 5.2.3.2 and 5.2.3.3.2 respectively. Thermal performance monitoring should be performed on each primary water heat exchanger in accordance with the requirements of Reference 5.9, not to exceed 10 years. Leak testing should be performed on these heat exchangers whenever tube sheet leaks are suspected.

Therefore, if visual inspection is performed once per 10-year inspection interval, thermal performance data is obtained and trended once per operating cycle (or other frequency determined to be adequate by plant specific operating history), and leak testing is performed to identify leaky tube sheet areas, then IGSCC of the heat exchanger tube sheet is effectively managed.

For a stainless steel heat exchanger shell, waterbox/channel ilead, and nozzles in a primary water application, volumetric, surface, and visual examinations and pressure testing should be 
performed in accordance with the plant's ASME Section XI Inservice Inspection and Testing Program. The required examinations for Class 2 heat exchangers (see Section 5.2.1.1) should be followed for these primary water heat exchanger applications. These shell, waterbox/channel head, and nozzle examinations are performed each 10-year inspection interval. The pressure tests are performed at least once each inspection period at a test pressure equal to the nominal operating pressure during system operation. Either a hydrostatic pressure test or the requirements of ASME Code Case N-498 is performed at or near the end of each 10-year inspection interval. The heat exchanger shell, waterbox/channel head, and nozzle exterior surfaces are visually examined for evidence of leakage during these pressure tests. Corrective action are implemented in accordance with the rules and requirements of ASME Section XI (see Section 5.2.1.3).

Therefore, if volumetric, surface, and visual examinations are performed on the heat exchanger shell, waterbox/channel head, and nozzles each 10-year inspection interval, and pressure testing is performed at least once each inspection period, then IGSCC of the primary water heat exchanger shell, waterbox/channel head, and nozzles is effectively managed.

For stainless steel heat exchanger shell side internals, visual inspections should be performed in accordance with the plant's Preventive Maintenance Program or ASME Operation and Maintenance Code Program, whichever applies. Visual inspection (see Section 5.2.3.3.1) is the most effective method to detect significant degradation and failure of the heat exchanger shell side internals due to IGSCC. Visual inspection should be performed on each primary water heat exchanger once per 10-year inspection interval.

If IGSCC causes the heat exchanger internals to become loose, then it is likely that vibration levels will increase. Vibration monitoring should be performed in accordance with either the plant's Preventive Maintenance Program or ASME Operation and Maintenance Code Program, whichever applies. Permanently installed vibration monitoring equipment would be the optimum; however, this is not a requirement to acquire the necessary data for analysis. Vibration monitoring should be performed on each primary water heat exchanger once per operating cycle and after major maintenance that changes the baseline vibration levels.

Therefore, if visual inspection is performed once per 10-year inspection interval, and vibration data is obtained and trended on the primary water heat exchangers once per operating cycle (or other frequency determined to be adequate by plant-specific operating history) and following major maintenance activities, then IGSCC of the heat exchanger internals is effectively managed.

For a stainless steel heat exchanger tube side divider plate, visual inspections should be performed in accordance with the plant's Preventive Maintenance Program or ASME Operation and Maintenance Code Program, whichever applies. Visual inspection (see Section 5.2.3.3.1) is the most effective method to detect significant degradation and failure of the heat exchanger tube side divider plate due to IGSCC. Visual inspection should be performed on each primary water heat exchanger once per 10-year inspection interval.

If IGSCC causes the divider plate to become detached or otherwise broken such that cooling water flow bypasses the tubes, then thermal capacity of the heat exchanger is diminished. Thermal performance monitoring should be performed in accordance with either the plant's 
Preventive Maintenance Program or ASME Operation and Maintenance Code Program, whichever applies. Section 5.2.3.2 describes several thermal performance monitoring methods that can be used to detect a failed heat exchanger divider plate. Thermal performance monitoring should be performed on each primary water heat exchanger in accordance with the requirements of Reference 5.9, not to exceed 10 years.

Therefore, if visual inspection is performed once per 10-year inspection interval and thermal performance data is obtained and trended on the primary water heat exchangers once per operating cycle (or other frequency determined to be adequate by plant specific operating history), then IGSCC of the heat exchanger tube side divider plate is effectively managed.

\subsubsection{Wear}

Detecting the presence of wear in the primary water system heat exchanger subcomponents is virtually impossible to achieve until such time as the subcomponent begins to exhibit abnormal behavior. Therefore, programs/techniques to effectively manage wear are generally performance based. Through heat exchanger performance monitoring and data acquisition, the trending of $\mathrm{kc} y$ operational parameters may provide sufficient information, prior to heat exchanger failure, so that planned maintenance activities can be conducted to repair/replace the affected heat exchanger subcomponent(s). Visual inspections and eddy current examinations are also helpful for wear detection in some situations. A combination of programs/techniques must be implemented to effectively manage wear of (1) BWR plant RWCU regenerative and non-regenerative heat exchangers and HPCI gland seal condensers, and (2) PWR plant CVC regenerative, letdown, excess letdown, and seal water heat exchangers and the RHR heat exchangers.

For stainless steel heat exchanger tubes in a primary water application, some form of vibration monitoring should be performed in accordance with either the plant's Preventive Maintenance Program or ASME Operation and Maintenance Code Program, whichever applies. Vibration monitoring is the most effective method to detect significant degradation and heat exchanger tube failure due to flow induced cyclic loading and wear. Permanently installed vibration monitoring equipment would be the optimum; however, this is not a requirement to acquire the necessary data for analysis. Section 5.2.3.3.4 describes three types of heat exchanger vibration measurement methods. Vibration monitoring should be performed on each primary water heat exchanger once per operating cycle and after major heat exchanger maintenance that changes the baseline vibration levels.

Eddy current examination methods performed in accordance with either the plant's Preventive Maintenance Program or ASME Operation and Maintenance Code Program, whichever applies, will identify and characterize flaws in non-ferromagnetic heat exchanger tubes. If the number or magnitude of cycle loads experienced produces wear flaws (i.e., denting) in the tubes, then eddy current testing is effective at detecting these flaws. It is not necessary for these flaws to propagate through the tube wall for eddy current testing to be effective. Eddy current testing (see Section 5.2.3.3.3) should be performed on each primary water heat exchanger at least once each 10-year inspection interval and whenever the heat exchanger is open for maintenance activities. 
If the number or magnitude of cyclic loading causes the heat exchanger tube to fail from wear such that through wall penetration occurs, then thermal performance monitoring and leak testing will effectively detect the tube failures. Thermal performance monitoring, and leak testing of heat exchangers is performed in accordance with either the plant's Preventive Maintenance or ASME Operation and Maintenance Code Program, whichever applies. Most heat exchangers are designed with heat transfer capacity margin such that a percentage of tubes can be plugged without impacting the ability of the heat exchanger to satisfy its required function. The thermal performance characteristics of the heat exchanger, however, decreases as the number of tubes that are plugged increases. Section 5.2.3.2 describes several thermal performance monitoring methods, and Section 5.2.3.3.2 describes several leak testing methods that can be used to detect failed heat exchanger tubes. Thermal performance monitoring should be performed on each primary water heat exchanger in accordance with the requirements of Reference 5.9, not to exceed 10 years. Leak testing should be performed on these heat exchangers whenever tube leaks are suspected.

Therefore, if vibration data and thermal performance data are obtained and trended on the primary water heat exchangers once per operating cycle (or other frequency determined to be adequate by plant-specific operating history) and following major maintenance activities, and eddy current testing and leak testing is performed to identify degraded and leaky tubes, then wear of the heat exchanger tubes is effectively managed.

For a stainless steel heat exchanger tube sheet in a primary water application, visual inspection should be performed in accordance with the plant's Preventive Maintenance Program or ASME Operation and Maintenance Code Program, whichever applies. Visual inspection (see Section 5.2.3.3.1) is the most effective method to detect significant degradation and heat exchanger tube sheet failure due to cyclic loading and wear. Visual inspection should be performed on each primary water heat exchanger once per 10-year inspection interval. In most instances, cracking occurs in the tube sheet ligaments (i.e., space between the holes) as described in Section 4.3.2.2.6. If ligament cracking propagates far enough, leakage across the tube sheet can be detected by thermal performance monitoring and leak testing methods as described in Sections 5.2.3.2 and 5.2.3.3.2, respectively. Thermal performance monitoring should be performed on each primary water heat exchanger in accordance with the requirements of Reference 5.9, not to exceed 10 years. Leak testing should be performed on these heat exchangers whenever tube sheet leaks are suspected.

Therefore, if visual inspection is performed once per 10-year inspection interval, and thermal performance data is obtained and trended once per operating cycle (or at another frequency determined to be adequate by plant-specific operating history), and leak testing is performed to identify leaky tube sheet areas, then wear of the heat exchanger tube sheet is effectively managed.

\subsubsection{Fouling}

Detecting the presence of fouling in the primary water system heat exchanger subcomponents is virtually impossible to achieve until such time as the subcomponent begins to exhibit abnormal behavior. Therefore, programs/techniques to effectively manage fouling are generally performance based. Through heat exchanger performance monitoring and data 
acquisition, the trending of key operational parameters may provide sufficient information, prior to heat exchanger failure, so that planned maintenance activities can be conducted to repair/ replace the affected heat exchanger subcomponent(s). Visual inspections and eddy current examinations are also helpful for fouling detection in some situations. A combination of program/techniques must be implemented to effectively manage fouling of the PWR plant CVC regenerative, letdown, excess letdown, and seal water heat exchangers and the RHR heat exchangers.

If precipitate fouling reaches the point where heat transfer capability begins to decrease from established levels, then thermal performance monitoring will effectively detect this degradation. Thermal performance monitoring of heat exchangers is performed in accordance with either the plant's Preventive Maintenance or ASME Operation and Maintenance Code Program, whichever applies. Most heat exchangers are designed with heat transfer capacity margin such that a certain amount of fouling can be tolerated without impacting the ability of the heat exchanger to satisfy its required function. The thermal performance characteristics of the heat exchanger, however, decreases as fouling of tubes increases. Section 5.2.3.2 describes several thermal performance monitoring methods that can be used to detect fouled heat exchanger tubes. Thermal performance monitoring should be performed on each primary water heat exchanger in accordance with the requirements of Reference 5.9, not to exceed 10 years.

Eddy current examination methods performed in accordance with either the plant's Preventive Maintenance Program or ASME Operations and Maintenance Code Program, whichever applies, may identify and characterize fouling of individual non-ferromagnetic heat exchanger tubes. Eddy current testing (see Section 5.2.3.3.3) should be performed on each primary water heat exchanger at least once each 10-year inspection interval and whenever the heat exchanger is open for maintenance activities.

Therefore, if thermal performance data is obtained and trended on PWR plant primary water heat exchangers once per operating cycle (or other frequency determined to be adequate by plant-specific operating history), and eddy current testing is performed to identify the fouled and degraded tubes, then fouling of the heat exchanger tubes is effectively managed.

For a stainless steel heat exchanger tube sheet in a PWR primary water application, visual inspection should be performed in accordance with the plant's Preventive Maintenance Program or ASME Operation and Maintenance Code Program, whichever applies. Visual inspection (see Section 5.2.3.3.1) is the most effective method to detect significant degradation and heat exchanger tube sheet failure due to fouling and deposits. Visual inspection should be performed on each primary water heat exchanger once per 10-year inspection interval. If fouling propagates far enough across the tube sheet, the tubes may become plugged which can be detected by thermal performance monitoring methods as described in Section 5.2.3.2. Thermal performance monitoring should be performed on each PWR primary water heat exchanger in accordance with the requirements of Reference 5.9, not to exceed 10 years.

Therefore, if visual inspection is performed once per 10-year inspection interval and thermal performance data obtained and trended once per operating cycle (or other frequency determined to be adequate by plant-specific operating history), then fouling of the heat exchanger tube sheet is effectively managed. 
For stainless steel heat exchanger shell and internals, waterbox/channel head/divider plate, and associated nozzles in a PWR plant primary water application, visual inspections should be performed in accordance with the plant's Preventive Maintenance Program or ASME Operation and Maintenance Code Program, whichever applies. Visual inspection (see Section 5.2.3.3.1) is the most effective method to detect fouling of the heat exchanger shell and internals, waterbox/channel head/divider plate, and associated nozzles. Visual inspection should be performed on PWR each primary water heat exchanger once per 10-year inspection interval.

Therefore, if visual inspection is performed once per 10-year inspection interval on the PWR plant primary water heat exchangers, then fouling of the shell and internals, waterbox/ channel head/divider plate, and associated nozzles is effectively managed.

\subsubsection{Erosion and Erosion/Corrosion}

From Section 4.3.2.3.5, erosion and erosion/corrosion were determined to be significant aging mechanisms for the primary water application heat exchanger shell/nozzles/internals that are made from carbon steel and are exposed to shell side fluid velocity of $1.8 \mathrm{~m} / \mathrm{s}[6$ ft/s] or greater.

The primary water heat exchanger shell/nozzles/internals made from carbon steel are the (1) BWR plant RWCU non-regenerative heat exchanger and the HPCI gland seal condenser, and (2) PWR plant CVC letdown, excess letdown, and seal water heat exchangers and the RHR heat exchangers. A review of Tables 3-5 and 3-6 shows that of these heat exchangers, only the HPCI gland seal condenser is exposed to primary water on the shell side.

The HPCI system is primarily operated intermittently for surveillance testing on a quarterly frequency. Each test typically takes from four to eight hours to complete. The primary water flowing through the gland seal condenser is extracted steam from the HPCI turbine seals and leakoff from the turbine stop and governor valves. Total flow, and therefore velocity, through the heat exchanger shell side, from these sources is very low (i.e., $<1.8 \mathrm{~m} / \mathrm{s}|6 \mathrm{ft} / \mathrm{s}|$ ). Therefore, if the HPCI gland seal condenser is operated only for testing purposes and velocity through the shell side is maintained within limits, then erosion and erosion/corrosion of the shell/nozzles/internals are not significant aging mechanisms and need not be managed.

\subsubsection{Stress Relaxation}

From Section 4.3.2.5.1, stress relaxation was determined to be a significant aging mechanism for the primary water application heat exchanger pressure boundary fasteners.

Volumetric examination is performed on heat exchanger pressure retaining bolts and studs greater than two inches in diameter. These examinations are performed each 10-year inspection interval in accordance with the plant's ASME Section XI Inservice Inspection and Testing Program for Class 2 heat exchangers. If stress relaxation of these pressure boundary fasteners occurs to a sufficient degree, the fastened joint will begin to leak fluid. Pressure tests are performed in accordance with the plant's ASME Section XI Inservice Inspection and Testing Program at least once each inspection period at a test pressure equal to the nominal operating pressure during system operation. Either a hydrostatic pressure test or the requirements of ASME 
Code Case N-498 is performed on these heat exchangers at or near the end of each 10-year inspection interval. The heat exchanger pressure boundary joints and associated fasteners are visually examined for evidence of leakage during these pressure tests. Stress relaxation of pressure boundary fasteners, regardless of shank diameter, will be detected and corrective actions implemented in accordance with the rules and requirements of ASME Section XI (see Section 5.2.1.3).

Therefore, if volumetric examinations are performed on bolts and studs greater than two inches in diameter each 10-year inspection interval, and pressure testing is performed at least once each inspection period on all primary water heat exchangers, then stress relaxation of the pressure boundary fasteners is effectively managed.

To further mitigate the potential for stress relaxation to occur in pressure boundary fasteners, Preventive Maintenance Program procedures should contain proper torquing requirements. This will ensure that the yield strength of the bolt or stud is not exceeded during installation.

\subsubsection{General Corrosion}

From Section 4.3.2.5.3, general corrosion was determined to be a significant aging mechanism for the pressure boundary fasteners in PWR plant primary water applications due to borated fluid corrosion in the event of joint leakage.

Volumetric examination is performed on the CVCS regenerative, excess letdown, letdown, and seal water heat exchanger $\mathrm{F}$ essure retaining bolts and studs greater than two inches in diameter. These examinations are performed each 10-year inspection interval in accordance with the plant's ASME Section XI Inservice Inspection and Testing Program for Class 2 heat exchangers. If general corrosion of these pressure boundary fasteners occurs to a sufficient degree, the fastened joint may begin to leak fluid. Pressure tests are performed in accordance with the plant's ASME Section XI Inservice Inspection and Testing Program at least once each inspection period at a test pressure equal to the nominal operating pressure during system operation. Either a hydrostatic pressure test or the requirements of ASME Code Case N-498 is performed on these heat exchangers at or near the end of each 10-year inspection interval. The heat exchanger pressure boundary joints and associated fasteners are visually examined for evidence of leakage during these pressure tests. General corrosion of pressure boundary fasteners, regardless of shank diameter, will be detected and corrective actions implemented in accordance with the rules and requirements of ASME Section XI (see Section 5.2.1.3).

Therefore, if volumetric examinations are performed on bolts and studs greater than two inches in diameter each 10-year inspection interval, and pressure testing is performed at least once each inspection period on all CVCS primary water heat exchangers, then general corrosion of the pressure boundary fasteners is effectively managed.

To further mitigate the potential for general corrosion to occur in pressure boundary fasteners, Preventive Maintenance Program procedures should contain requirements to coat the fasteners following installation with a lubricant or other approved corrosion protection coating. 


\subsubsection{Treated Water System Heat Exchangers}

From Tables 3-5 and 3-6 (i.e., tube side and shell side fluids), the treated water system heat exchangers discussed in this section are the (1) BWR - HPCI System lubrication oil cooler and gland seal condenser, RCIC System lubrication oil cooler, Spent Fuel Pool (SFP) System heat exchangers, and RHR System heat exchangers, and (2) PWR - SFP System heat exchangers. These heat exchangers were evaluated by subcomponent and the associated aging mechanisms, determined in Section 4.3, to be significant are:

- Tubes

- Mechanical Fatigue

- Microbiologically Influenced Corrosion

- Erosion and Erosion/Corrosion

- Wear

- Fouling

- Tube Sheets

- Mechanical Fatigue

- General Corrosion

- Microbiologically Influenced Corrosion

- Intergranular and Transgranular Stress Corrosion Cracking

- Erosion and Erosion/Corrosion

- Wear

- Fouling

- Shell/Nozzles/Internals

- Mechanical Fatigue

- General Corrosion

- Microbiologically Influenced Corrosion

- Galvanic Corrosion

- Erosion and Erosion/Corrosion

- Fouling

- Waterbox/Channel Head/Divider Plate

- Mechanical Fatigue

- General Corrosion

- Microbiologically Influenced Corrosion

- Galvanic Corrosion

- Erosion and Erosion/Corrosion

- Fouling 
- Pressure Boundary Fasteners/Support Assembly

- None

The following programs/techniques are considered effective for detection and mitigation of these aging mechanisms.

- Mechanical Fatigue

- ASME Section XI Inservice Inspection and Testing

- Preventive Maintenance

- ASME Operation and Maintenance Code

- General Corrosion

- ASME Section XI Inservice Inspection and Testing

- Preventive Maintenance

- ASME Operation and Maintenance Code

- Microbiologically Influenced Corrosion

- MIC Control Program

- Galvanic Corrosion

- ASME Section XI Inservice Inspection and Testing

- Preventive Maintenance

- ASME Operation and Maintenance Code

- Intergranular and Transgranular Stress Corrosion Cracking

- Preventive Maintenance

- ASME Operation and Maintenance Code

- Erosion and Erosion/Corrosion

- ASME Section XI Inservice Inspection and Testing

- Preventive Maintenance

- ASME Operation and Maintenance Code

- Wear

- Preventive Maintenance

- ASME Operation and Maintenance Code 

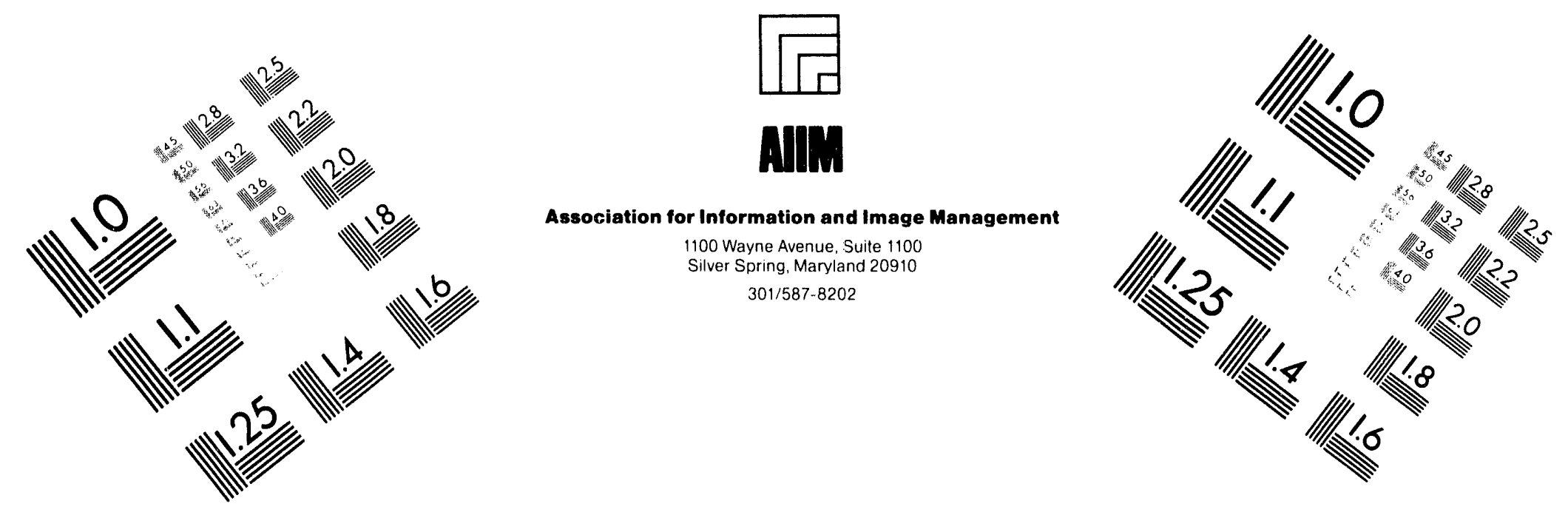

\section{Centimeter}

|

Inches
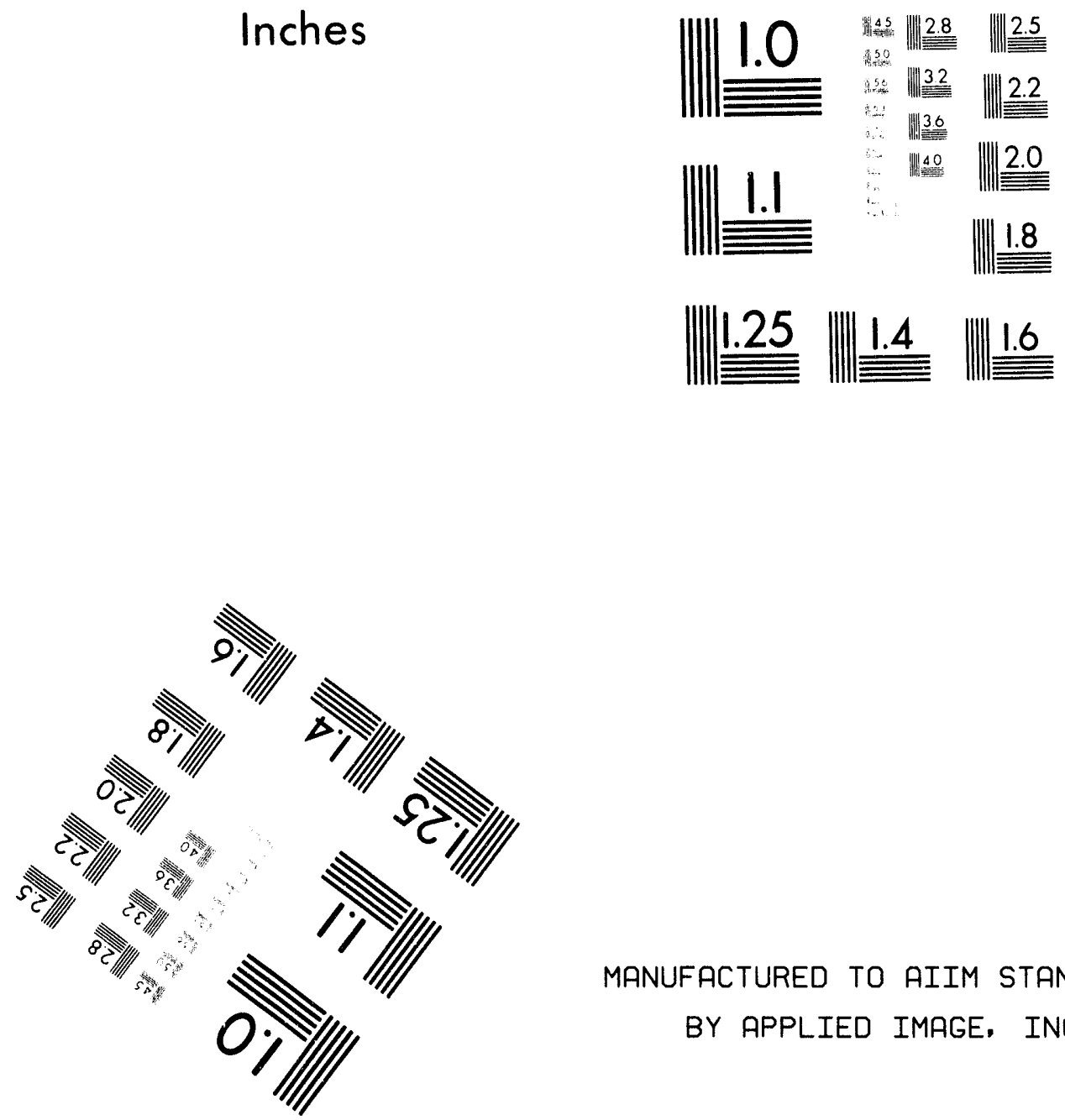

MANUFACTURED TO AIIM STANDARDS

BY APPLIED IMAGE, INC.

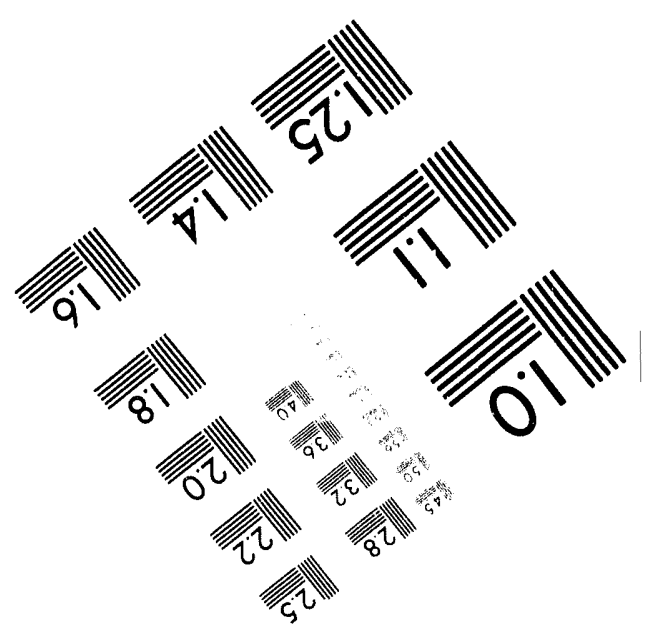



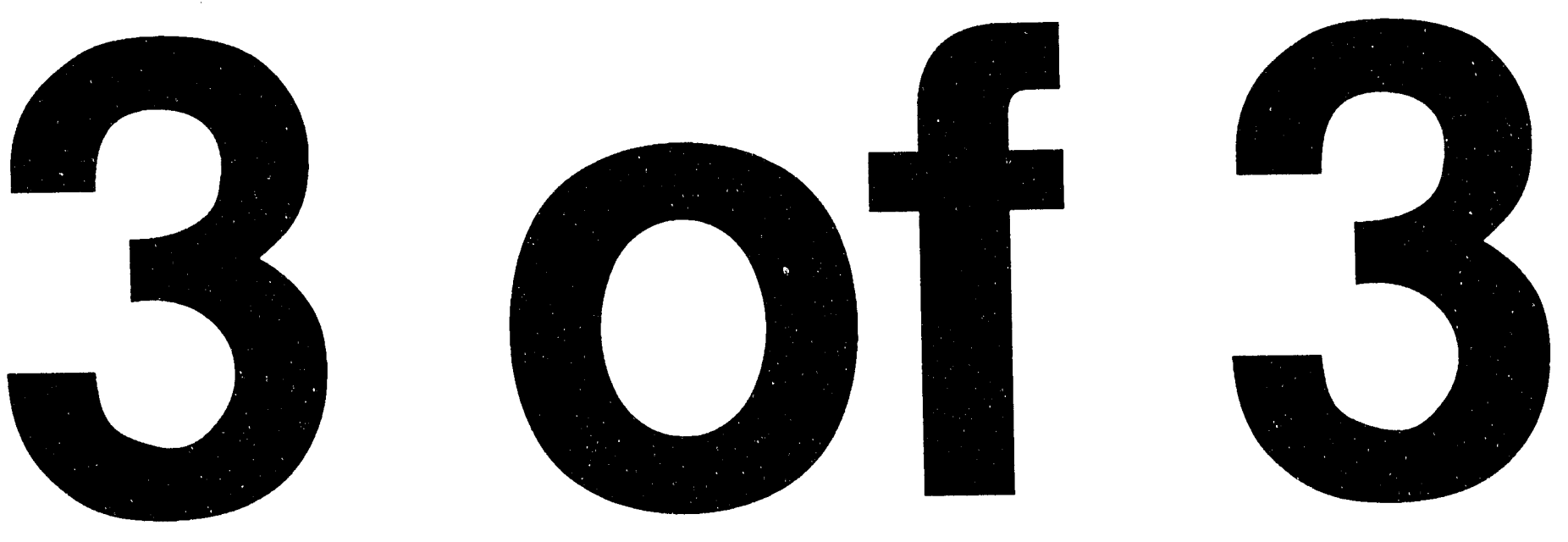
- Fouling

- Preventive Maintenance

- ASME Operation and Maintenance Code

Table 5-3 summarizes the results and conclusions associated with the following effective program/technique evaluations.

\subsubsection{Mechanical Fatigue}

Detecting the presence of mechanical fatigue in treated water system heat exchanger subcomponents is virtually impossible to achieve until such time as the subcomponent begins to exhibit abnormal behavior. Therefore, programs/techniques to effectively manage mechanical fatigue are generally performance based. Through heat exchanger performance monitoring and data acquisition, the trending of key operational parameters may provide sufficient information, prior to heat exchanger failure, so that planned maintenance activities can be conducted to repair/replace the affected heat exchanger subcomponent(s). Visual inspections and eddy current examinations are also helpful for fatigue detection in some situations. A combination of programs/techniques must be implemented to effectively manage mechanical fatigue of (1) BWR plant HPCI System lubrication oil cooler and gland seal condenser, RCIC System lubrication oil cooler, SFP System heat exchangers and RHR System heat exchangers and (2) PWR plant SFP System heat exchangers.

For heat exchanger tubes (i.e., stainless steel, admiralty brass or copper-nickel) in a treated water application, some form of vibration monitoring should be performed in accordance with either the plant's Preventive Maintenance Program or ASME Operation and Maintenance Code Program, whichever applies. Vibration monitoring is the most effective method to detect significant degradation and heat exchanger tube failure due to flow induced cyclic loading and mechanical fatigue. Permanently installed vibration monitoring equipment would be the optimum; however, this is not a requirement to acquire the necessary data for analysis. Section 5.2.3.3.4 describes three types of heat exchanger vibration measurement methods. Vibration monitoring should be performed on each treated water heat exchanger once per operating cycle and after major heat exchanger maintenance that changes the baseline vibration levels.

Eddy current examination methods performed in accordance with either the plant's Preventive Maintenance Program or ASME Operation and Maintenance Code Program, whichever applies, will identify and characterize flaws in non-ferromagnetic heat exchanger tubes. If the number or magnitude of cyclic loads experienced produces fatigue flaws (i.e., fretting) in the tubes, then eddy current testing is effective at detecting these flaws. It is not necessary for these flaws to propagate through the tube wall for eddy current testing to be effective. Eddy current testing (see Section 5.2.3.3.3) should be performed on each treated water heat exchanger at least once each 10-year inspection interval and whenever the heat exchanger is open for maintenance activities. 
AGING MANAGEMENT GUIDELINE FOR HEìT FXCHANGERS

\begin{tabular}{|c|c|c|c|c|c|c|c|}
\hline \multirow[b]{2}{*}{$\begin{array}{l}\text { Heat Exchanger } \\
\text { Subcomponent }\end{array}$} & \multicolumn{4}{|c|}{ Conventional Programs/Techniques Commonly Used } & \multicolumn{3}{|c|}{ Non-Conventional Programs/Techniques Commonly Used } \\
\hline & $\begin{array}{l}\text { ASME Sect. XI. } \\
\text { ISI and IST }\end{array}$ & $\begin{array}{l}\text { ASME Operations and } \\
\text { Maintenance Standards }\end{array}$ & $\begin{array}{c}\text { Preventive } \\
\text { Maintenance }\end{array}$ & $\begin{array}{c}\text { MIC } \\
\text { Control }\end{array}$ & Lay-up & Operator Activities & Coatings Survey \\
\hline Tubes/Coils & & $\begin{array}{l}\text { Thermal Performance } \\
\text { Leak Testing } \\
\text { Eddy Current } \\
\text { Vibration Monitoring }\end{array}$ & $\begin{array}{l}\text { Thermal Performance } \\
\text { Leak Testing } \\
\text { Eddy Current } \\
\text { Vibration Monitoring }\end{array}$ & $\begin{array}{l}\text { Sampling } \\
\text { Treatment }\end{array}$ & Preservation & & \\
\hline Tube Sheet & & $\begin{array}{l}\text { Visual Inspection } \\
\text { Thermal Performance } \\
\text { Leak Testing }\end{array}$ & $\begin{array}{l}\text { Visual Inspection } \\
\text { Thermal Performance } \\
\text { Leak Testing }\end{array}$ & $\begin{array}{l}\text { Sampling } \\
\text { Treatment }\end{array}$ & Preservation & & \\
\hline $\begin{array}{l}\text { Shell/Nozzles/ } \\
\text { Internals }\end{array}$ & $\begin{array}{l}\text { Volumetric Examination } \\
\text { Surface Examination } \\
\text { Visual Examination } \\
\text { Pressure Testing }\end{array}$ & $\begin{array}{l}\text { Visual Inspection } \\
\text { Vibration Monitoring }\end{array}$ & $\begin{array}{l}\text { Visual Inspection } \\
\text { Vibration Monitoring }\end{array}$ & $\begin{array}{l}\text { Sampling } \\
\text { Treatment }\end{array}$ & Preservation & Inspections & Inspections \\
\hline $\begin{array}{l}\text { Waterbox/ } \\
\text { Channel Head/ } \\
\text { Divider Plate }\end{array}$ & $\begin{array}{l}\text { Volumetric Examination } \\
\text { Surface Examination } \\
\text { Visual Examination } \\
\text { Pressure Testing }\end{array}$ & $\begin{array}{l}\text { Visual Inspection } \\
\text { Thermal Performance }\end{array}$ & $\begin{array}{l}\text { Visual Inspection } \\
\text { Thermal Performance }\end{array}$ & $\begin{array}{l}\text { Sampling } \\
\text { Treatment }\end{array}$ & Preservation & Inspections & Inspections \\
\hline $\begin{array}{l}\text { Pressure Boundary } \\
\text { Fasteners/Support } \\
\text { Assembly }\end{array}$ & & & & & & & \\
\hline
\end{tabular}


If the number or magnitude of cyclic loading causes the heat exchanger tube to fail from mechanical fatigue such that t'rough wall penetration occurs, then thermal performance monitoring and leak testing will effectively detect the tube failures. Thermal performance monitoring and leak testing of heat exchangers is performed in accordance with either the plant's Preventive Maintenance or ASME Operation and Maintenance Code Program, whichever applies. Most heat exchangers are designed with heat transfer capacity margin such that a percentage of tubes can be plugged without impacting the ability of the heat exchanger to satisfy its required function. The thermal performance characteristics of the heat exchanger however, decreases as the number of tubes that are plugged increases. Section 5.2.3.2 describes several thermal performance monitoring methods, and Section 5.2.3.3.2 describes several leak testing methods that can be used to detect failed heat exchanger tubes. Thermal performance monitoring should be performed on each treated water heat exchanger in accordance with the requirements of Reference 5.9, not to exceed 10 years. Leak testing should be performed on these heat exchangers whenever tube leaks are suspected.

Therefore, if vibration data and thermal performance data are obtained and trended on the treated water heat exchangers once per operating cycle (or other frequency determined to be adequate by plant-specific operating history) and following major maintenance activities, and eddy current testing and leak testing is performed to identify degraded and leaky tubes, then mechanical fatigue of the heat exchanger tubes is effectively managed.

For a heat exchanger tube sheet (i.e., stainless steel, muntz metal, or carbon steel) in a treated water application, visual inspection should be performed in accordance with the plant's Preventive Maintenance Program or ASME Operation and Maintenance Code Program, whichever applies. Visual inspection (see Section 5.2.3.3.1) is the most effective method to detect significant degradation and heat exchanger tube sheet failure due to cyclic loading and mechanical fatigue. Visual inspection should be performed on each treated water heat exchanger once per 10-year inspection interval. From Section 4.3.2.2.2 in most instances, fatigue cracking occurs in the tube sheet ligaments (i.e., space between the holes). If ligament cracking propagates far enough, leakage across the tube sheet can be detected by thermal performance monitoring and leak testing methods as described in Sections 5.2.3.2 and 5.2.3.3.2, respectively. Thermal performance monitoring should be performed on each treated water heat exchanger in accordance with the requirements of Reference 5.9, not to exceed 10 years. Leak testing should be performed on these heat exchangers whenever lube sheet leaks are suspected.

Therefore, if visual inspection is performed once per 10-year inspection interval and thermal performance data obtained and trended once per operating cycle (or other frequency determined to be adequate by plant-specific operating history), and leak testing is performed to identify leaky tube sheet areas, then mechanical fatigue of the heal exchanger tube sheet is effectively managed.

For an ASME Class 2 heat exchanger shell, waterbox/channel head, and nozzles (i.e., stainless steel or (arbon steel) in a treated water application, volumetric, surface, and visual examinations, and pressure testing should be performed. For an ASME Class 3 heat exchanger shell, waterbox/channel head, and nozzle. in a treated water application, pressure testing is an effective program. These examinations are performed in accordance with the plant's ASME Section XI Inservice Inspection and Testing Program (see Sections 5.2.1.1 and 5.2.1.2). The 
examinations on ASME Class 2 heat exchangers are performed each 10-year inspection interval, and the pressure tests on both ASME Class 2 and 3 heat exchangers are performed at least once each inspection period. Pressure tests are performed at a value equal to the nominal operating pressure during system operation. Either a hydrostatic pressure test or a test satisfying the requirements of ASME Code Case N-498 is performed on ASME Class 2 heat exchangers, and hydrostatic pressure testing is performed on the ASME Class 3 heat exchangers. These tests are performed at or near the end of each 10-year inspection interval. The heat exchanger shell, waterbox/channel head, and nozzle exterior surfaces are visually examined for evidence of leakage during these pressure tests. Corrective actions are implemented in accordance with the rules and requirements of ASME Section XI (see Section 5.2.1.3).

Therefore, if volumetric, surface, and visual examinations are performed on the ASME Class 2 heat exchanger shell, waterbox/channel head, and nozzles each 10-year inspection interval, and pressure testing is performed on both ASME Class 2 and 3 heat exchangers at least once each inspection period, then mechanical fatigue of the heat exchanger shell, waterbox/channel head, and nozzles in treated water applications is effectively managed.

A review of Tables 3-5 and 3-6 shows that the only heat exchangers in the scope of this AMG with treated water on the shell side are the BWR plant RHR heat exchangers. For carbon steel RHR heat exchanger shell side internals, visual inspections should be performed in accordance with the plant's Preventive Maintenance Program or ASME Operation and Maintenance Code Program, whichever applies. Visual inspection (see Section 5.2.3.3.1) is the most effective method to detect significant degradation and failure of the RHR heat exchanger shell side internals due to cyclic loading and mechanical fatigue. Visual inspection should be performed on the RHR heat exchanger shell side once per 10-year inspection interval.

If mechanical fatigue causes the RHR heat exchanger internals to become loose, then it is likely that vibration levels will increase. Vibration monitoring should be performed in accordance with either the plant's Preventive Maintenance Program or ASME Operation and Maintenance Code Program, whichever applies. Permanently installed vibration monitoring equipment would be the optimum; however, this is not a requirement to acquire the necessary data for analysis. Vibration monitoring should be performed on the RHR heat exchangers once per operating cycle and after major maintenance that changes the baseline vibration levels.

Therefore, if visual inspection is performed once per 10-year inspection interval and vibration data is obtained and trended on the RHR heat exchangers once per operating cycle (or other frequency determined to be adequate by plant-specific operating history) and following major maintenance activities, then mechanical fatigue of the RHR heat exchanger internals is effectively managed.

For a heat exchanger tube side divider plate (i.e., carbon steel or stainless steel), visual inspections should be performed in accordance with the plant's Preventive Maintenance Program or ASME Operation and Maintenance Code Program, whichever applies. Visual inspection (see Section 5.2.3.3.1) is the most effective method to detect significant degradation and failure of the heat exchanger tube side divider plate due to cyclic loading and mechanical fatigue. Visual inspection should be performed on each treated water heat exchanger once per 10-year inspection interval. 
If mechanical fatigue causes the divider plate to become detached or otherwise broken such that cooling water flow bypasses the tubes, then the thermal capacity of the heat exchanger is diminished. Thermal performance monitoring should be performed in accordance with either the plant's Preventive Maintenance Program or ASME Operation and Maintenance Code Program, whichever applies. Section 5.2.3.2 describes several thermal performance monitoring methods that can be used to detect a failed heat exchanger divider plate. Thermal performance monitoring should be performed on each treated water heat exchanger in accordance with the requirements of Reference 5.9 , not to exceed 10 years.

Therefore, if visual inspection is performed once per 10-year inspection interval and thermal performance data is obtained and trended on the treated water heat exchangers once per operating cycle (or other frequency determined to be adequate by plant-specific operating history), then mechanical fatigue of the heat exchanger tube side divider plate and tube sheet is effectively managed.

\subsubsection{General Corrosion}

From Section 4.3.2, general corrosion (i.e., by dezincification) of muntz metal tube sheets and general corrosion (i.e., uniform wastage) of carbon steel tube sheets, shell/nozzles/internals, and waterbox/channel head/divider plate in treated water applications must be effectively managed.

For the ASME Class 2 heat exchanger shell, waterbox/channel head, and nozzles (i.e., stainless steel or carbon steel) in treated water applications volumetric, surface, and visual examinations, and pressure testing should be performed. For the ASME Class 3 heat exchanger shell, waterbox/channel head and nozzles in treated water applications, pressure testing is an effective program. These examinations are performed in accordance with the plant's ASME Section XI Inservice Inspection and Testing Program (see Sections 5.2.1.1 and 5.2.1.2). The examinations on ASME Class 2 heat exchangers are performed each 10-year inspection interval, and the pressure tests on both ASME Class 2 and 3 heat exchangers are performed at least once each inspection period. Pressure tests are performed at a value equal to the nominal operating pressure during system operation. Either a hydrostatic pressure test or a test satisfying the requirements of ASME Code Case N-498 is performed on ASME Class 2 heat exchangers, and a hydrostatic pressure test is performed on ASME Class 3 heat exchangers. These tests are performed at or near the end of each 10-year inspection interval. The heat exchanger shell, waterbox/channel head, and nozzle exterior surfaces are visually examined for evidence of leakage during these pressure tests. Corrective actions are implemented in accordance with the rules and requirements of ASME Section XI (see Section 5.2.1.3).

Therefore, if volumetric, surface, and visual examinations are performed on the ASME Class 2 heat exchanger shell, waterbox/channel head, and nozzles each 10-year inspection interval, and pressure testing is performed on both ASME Class 2 and 3 heat exchangers at least once each inspection period, then general corrosion of the heat exchanger shell, waterbox/channel head, and nozzles in treated water applications is effectively managed.

A review of Tables 3-5 and 3-6 shows that the only heat exchangers in the scope of this AMG with treated water on the shell side are the BWR plant RHR heat exchangers. For these 
carbon steel RHR heat exchanger shell side internals, visual inspections should be performed in accordance with the plant's Preventive Maintenance Program or ASME Operation and Maintenance Code Program, whichever applies. Visual inspection (see Section 5.2.3.3.1) is the most effective method to detect significant degradation and failure of the RHR heat exchanger shell side internals due to general corrosion. Visual inspection should be performed on the RHR heat exchanger shell side once per 10-year inspection interval.

If general corrosion loosens RHR heat exchanger internals, then it is likely that vibration levels will increase. Vibration monitoring should be performed in accordance with either the plant's Preventive Maintenance Program or ASME Operation and Maintenance Code Program, whichever applies. Permanently installed vibration monitoring equipment would be the optimum; however, this is not a requirement to acquire the necessary data for analysis. Vibration monitoring should be performed on the RHR heat exchangers once per operating cycle and after major maintenance that changes the baseline vibration levels.

Therefore, if visual inspection is performed once per 10-year inspection interval and vibration data is obtained and trended on the RHR heat exchangers once per operating cycle (or other frequency determined to be adequate by plant-specific operating history) and following major maintenance activities, then general sorrosion of the RHR heat exchanger internals is effectively managed.

For a carbon steel heat exchanger tube side divider plate and carbon steel or muntz metal tube sheets, visual inspections should be performed in accordance with the plant's Preventive Maintenance Program or ASME Operation and Maintenance Code Program, whichever applies. Visual inspection (see Section 5.2.3.3.1) is the most effective method to detect significant degradation and failure of the heat exchanger tube side divider plate and tube sheet due to general corrosion. Visual inspection should be performed on each treated water heat exchanger once per 10-year inspection interval.

If general corrosion causes the divider plate to become detached or otherwise broken or the tube sheet to corrode through such that cooling water flow bypasses the tubes, then the thermal capacity of the heat exchanger is diminished. Thermal performance monitoring should be performed in accordance with either the plant's Preventive Maintenance Program or ASME Operation and Maintenance Code Program, whichever applies. Section 5.2.3.2 describes several thermal performance monitoring methods that can be used to detect a failed heat exchanger divider plate or tube sheet. Thermal performance monitoring should be performed on each treated water heat exchanger in accordance with the requirements of Reference 5.9, not to exceed 10 years.

Therefore, if visual inspection is performed once per 10-year inspection interval and thermal performance data is obtained and trended on the treated water heat exchangers once per operating cycle (or other frequency determined to be adequate by plant specific operating history), then general corrosion of the heat exchanger tube side divider plate and tube sheet is effectively managed. 


\subsubsection{Microbiologically Influenced Corrosion}

From Section 4.3.2, MIC of heat exchanger tubes, tube sheets, shell/nozzles/internals, and waterbcx/channel head/divider plate subcomponents in treated water applications must be effectively managed regardless of material types.

Sampling of the treated water at the source (i.e., spent fuel pool and suppression pool) and immediately upstream and downstream from the heat exchanger should be performed quarterly in accordance with the plant's MIC Control Program. Sampling and analysis, and associated trending of the data, on a quarterly basis is sufficient to assess seasonal variations $i:$ the microbial content, oxygen level, and critical nutrients of the treated water. Appropriate treatment methods, as delineated in Section 5.2.4.3, can then be implemented to effectively mitigate the effects of MIC.

When the treated water heat exchanger is open for maintenance purposes or for visual inspection (i.e., once per 10-year inspection interval), solid samples of corrosion products, deposits, or tubercules should be removed and a detailed chemical and microbiological examination performed. Additional visual examination and possibly metal samples of the under deposit area should also be performed in accordance with the plant's MIC Control Program. Analysis and trending of the solid sample and metallurgical data, if appropriate, may lead to better treatment methods that will mitigate the effects of MIC.

Therefore, if sampling and analysis of the treated water upstream and downstream from the heat exchanger is performed quarterly (or other frequency determined to be adequate by plant-specific operating history) and solid sampling and analysis is performed whenever the heat exchanger is open for maintenance or inspection, then MIC of the heat exchanger tubes, tube sheet, shell/nozzles/internals, and waterbox/channel head/divider plate in treated water applications is effectively managed.

\subsubsection{Galvanic Corrosion}

From Section 4.3.2..3 and 4.3.2.4.3, if the carbon and low alloy steel heat exchanger shell/ nozzles/internals and waterbox/channel head/divider plate are exposed to treated water and these subcomponents are in physical contact with other stainless steel and/or copper alloy subcomponents (i.e., tube sheet, etc.), and sacrificial anodes are not utilized, then galvanic corrosion must be managed.

For an ASME Class 2 heat exchanger shell, waterbox/channel head, and nozzles, volumetric, surface, and visual examinations and pressure testing should be performed. For the ASME Class 3 heat exchanger shell, waterbox/channel head and nozzles in these treated water applications, pressure testing is an effective program. These examinations are performed in accordance with the plant's ASME Section XI Inservice Inspection and Testing Program (see Sections 5.2.1.1 and 5.2.1.2). The examinations on ASME Class 2 heat exchangers are performed each 1()-year inspection interval, and the pressure tests on both ASME Class 2 and 3 heat exchangers are performed at least once each inspection period. Pressure tests are performed at a value equal to the nominal operating pressure during system operation. Either a hydrostatic pressure test or a test satisfying the requirements of ASME Code Case N-498 is performed on 


\section{AGING MANAGEMENT GUIDELINE FOR HEAT EXCHANGERS}

ASME Class 2 heat exchangers, and a hydrostatic pressure test is performed on ASME Class 3 heat exchangers. These tests are performed at or near the end of each 10-year inspection interval. The heat exchanger shell, waterbox/ channel head, and nozzle exterior surfaces are visually examined for evidence of leakage during these pressure tests. Corrective actions are implemented in accordance with the rules and requirements of ASME Section XI (see Section 5.2.1.3).

Therefore, if volumetric, surface, and visual examinations are performed on the ASME Class 2 heat exchanger shell, waterbox/channel head, and nozzles each 10-year inspection interval, and pressure testing is performed on both ASME Class 2 and 3 heat exchangers at least once each inspection period, then galvanic corrosion of the heat exchanger shell, waterbox/ channel head, and nozzles in treated water applications is effectively managed.

A review of Tables 3-5 and 3-6 shows that the only heat exchangers in the scope of this AMG with treated water on the shell side are the BWR plant RHR heat exchangers. For carbon steel RHR heat exchanger shell side internals, visual inspections should be performed in accordance with the plant's Preventive Maintenance Program or ASME Operation and Maintenance Code Program, whichever applies. Visual inspection (see Section 5.2.3.3.1) is the most effective method to detect significant degradation and failure of the RHR heat exchanger shell side internals due to galvanic corrosion. Visual inspection should be performed on the RHR heat exchanger shell side once per 10-year inspection interval.

If galvanic corrosion causes the RHR heat exchanger internals to become loose, then it is likely that vibration levels will increase. Vibration monitoring should be performed in accordance with either the plant's Preventive Maintenance Program or ASME Operation and Maintenance Code Program, whichever applies. Permanently installed vibration monitoring equipment would be the optimum; however, this is not a requirement to acquire the necessary data for analysis. Vibration monitoring should be performed on the RHR heat exchangers once per operating cycle and after major maintenance that changes the baseline vibration levels.

Therefore, if visual inspection is performed once per 10-year inspection interval and vibration data is obtained and trended on the RHR heat exchangers once per operating cycle (or other frequency determined to be adequate by plant-specific operating history); then galvanic corrosion of the RHR heat exchanger internals is effectively managed.

For a carbon and low alloy steel heat exchanger tube side divider plate, visual inspections should be performed in accordance with the plant's Preventive Maintenance Program or ASME Operation and Maintenance Code Program, whichever applies. Visual inspection (see Section 5.2.3.3.1) is the most effective method to detect significant degradation and failure of the heat exchanger tube side divider plate due to galvanic corrosion. Visual inspection should be performed on each treated water heat exchanger once per 10-year inspection interval.

If galvanic corrosion causes the divider plate to become detached or otherwise broken such that cooling water flow bypasses the tubes, then the thermal capacity of the heat exchanger is diminished. Thermal performance monitoring should be performed in accordance with either the plant's Preventive Maintenance Program or ASME Operation and Maintenance Code Program, whichever applies. Section 5.2.3.2 describes several thermal performance monitoring methods that can be used to detect a failed heat exchanger divider plate. Thermal performance 
monitoring should be performed on each treated water heat exchanger in accordance with the requirements of Reference 5.9 , not to exceed 10 years.

Therefore, if visual inspection is performed once per 10-year inspection interval and thermal performance data is obtained and trended on the treated water heat exchangers once per operating cycle (or other frequency determined to be adequate by plant-specific operating history), then galvanic corrosion of the heat exchanger tube side divider plate is effectively managed.

\subsubsection{Intergranular and Transgranular Stress Corrosion Cracking}

From Section 4.3.2.2.4, IGSCC and TGSCC of muntz metal tube sheets exposed to treated water applications are required to be effectively managed.

For a muntz metal heat exchanger tube sheet in a treated water application, visual inspection should be performed in accordance with the plant's Preventive Maintenance Program or ASME Operation and Maintenance Code Program, whichever applies. Visual inspection (see Section 5.2.3.3.1) is the most effective method to detect significant degradation and heat exchanger tube sheet failure due to IGSCC and/or TGSCC. Visual inspection should be performed on each of these treated water heat exchangers once per 10-year inspection interval. If cracking propagates far enough, leakage across the tube sheet can be detected by thermal performance monitoring and leak testing methods as described in Sections 5.2.3.2 and 5.2.3.3.2, respectively. Thermal performance monitoring should be performed on each of these treated water heat exchangers in accordance with the requirements of Reference 5.9, not to exceed 10 years. Leak testing should be performed on these heat exchangers whenever tube sheet leaks are suspected.

Therefore, if visual inspection is performed once per 10-year inspection interval and thermal performance data is obtained and trended once per operating cycle (or other frequency determined to be adequate by plant-specific operating history), and leak testing is performed to identify leaky tube sheet areas, then IGSCC and TGSCC of the heat exchanger tube sheet is effectively managed.

\subsubsection{Erosion and Erosion/Corrosion}

From Sections 4.3.2.1.5, 4.3.2.2.5, 4.3.2.3.5, and 4.3.2.4.5, erosion and erosion/corrosion must be effectively managed for the following heat exchanger components subject to treated water.

- Tubes made from admiralty brass or copper nickel alloys.

- Tube sheets made from muntz metal or carbon steel.

- BWR plant RHR heat exchanger shell/nozzles/internals made from carbon steel and exposed to shell side fluid velocity that is greater than specified limits.

- Waterbox/channel head/divider plate made from carbon steel. 
Eddy current examination methods performed in accordance with either the plant's Preventive Maintenance Program or ASME Operation and Maintenance Code Program, whichever applies, will identify and characterize flaws in non-ferromagnetic heat exchanger tubes. If erosion and erosion/corrosion produces flaws in the tubes, then eddy current testing is effective at detecting these flaws. It is not necessary for these flaws to propagate through the tube wall for eddy current testing to be effective. Eddy current testing (see Section 5.2.3.3.3) should be performed on each treated water heat exchanger at least once each 10-year inspection interval and whenever the heat exchanger is open for maintenance activities.

If erosion and erosion/corrosion causes the heat exchanger tube to fail such that through wall penetration occurs, then thermal performance monitoring and leak testing will effectively detect the tube failures. Thermal performance monitoring and leak testing of heat exchangers is performed in accordance with either the plant's Preventive Maintenance or ASME Operation and Maintenance Code Program, whichever applies. Most heat exchangers are designed with heat transfer capacity margin such that a percentage of tubes can be plugged without impacting the ability of the heat exchanger to satisfy its required function. The thermal performance characteristics of the heat exchanger, however, decreases as the number of plugged tubes increases. Section 5.2.3.2 describes several thermal performance monitoring methods, and Section 5.2.3.3.2 describes several leak testing methods that can be used to detect failed heat exchanger tubes. Thermal performance monitoring should be performed on each treated water heat exchanger in accordance with the requirements of Reference 5.9, not to exceed 10 years. Leak testing should be performed on these heat exchangers whenever tube leaks are suspected.

Therefore, if thermal performance data is obtained and trended on the treated water heat exchangers once per operating cycle (or other frequency determined to be adequate by plantspecific operating history), and eddy current testing and leak testing is performed to identify degraded and leaky tubes, then erosion and erosion/corrosion of the heat exchanger tubes is effectively managed.

For a heat exchanger tube sheet (i.e., stainless steel, muntz metal, or carbon steel) in a treated water application, visual inspection should be performed in accordance with the plant's Preventive Maintenance Program or ASME Operation and Maintenance Code Program, whichever applies. Visual inspection (see Section 5.2.3.3.1) is the most effective method to detect significant degradation and heat exchanger tube sheet failure due to erosion and erosion/corrosion. Visual inspection should be performed on each treated water heat exchanger once per 10-year inspection interval. If erosion and erosion/corrosion propagates far enough, leakage across the tube sheet can be detected by thermal performance monitoring and leak testing methods as described in Sections 5.2.3.2 and 5.2.3.3.2, respectively. Thermal performance monitoring should be performed on each treated water heat exchanger in accordance with the requirements of Reference 5.9, not to exceed 10 years. Leak testing should be performed on these heat exchangers whenever tube sheet leaks are suspected.

Therefore, if visual inspection is performed once per 10-year inspection interval, and thermal performance data is obtained and trended once per operating cycle (or at another frequency determined to be adequate by plant-specific operating history), and leak testing is performed to identify leaky tube sheet areas, then erosion and erosion/corrosion of the heat exchanger tube sheet is effectively managed. 
For an ASME Class 2 heat exchanger shell, waterbox/channel head, and nozzles (i.e., carbon steel) in a treated water application, volumetric, surface, and visual examinations, and pressure testing should be performed. For the ASME Class 3 heat exchanger shell, waterbox/ channel head and nozzles in treated water applications, pressure testing is an effective program. These examinations are performed in accordance with the plant's ASME Section XI Inservice Inspection and Testing Program (see Sections 5.2.1.1 and 5.2.1.2). The examinations on ASME Class 2 heat exchangers are performed each 10-year inspection interval, and the pressure tests on both ASME Class 2 and 3 heat exchangers are performed at least once each inspection period. Pressure tests are performed at a value equal to the nominal operating pressure during system operation. Either a hydrostatic pressure test or a test satisfying the requirements of ASME Code Case N-498 is performed on ASME Class 2 heat exchangers, and a hydrostatic pressure test is performed on the ASME Class 3 heat exchangers. These tests are performed at or near the end of each 10-year inspection interval. The heat exchanger shell, waterbox/channel head, and nozzle exterior surfaces are visually examined for evidence of leakage during these pressure tests. Corrective actions are implemented in accordance with the rules and requirements of ASME Section XI (see Section 5.2.1.3).

The. afore, if volumetric, surface, and visual examinations are performed on the ASME Class 2 heat exchanger shell, waterbox/channel head, and nozzles each 10-year inspection interval, and pressure testing is performed on both ASME Class 2 and 3 heat exchangers at least once each inspection period, then erosion and erosion/corrosion of the heat exchanger shell, waterbox/channel head, and nozzles in treated water applications is effectively managed.

A review of Tables 3-5 and 3-6 shows that the only heat exchanger in the scope of this AMG with treated water on the shell side are the BWR plant RHR heat exchangers. For these carbon steel RHR heat exchanger shell side internals, visual inspections should be performed in accordance with the plant's Preventive Maintenance Program or ASME Operation and Maintenance Code Program, whichever applies. Visual inspection (see Section 5.2.3.3.1) is the most effective method to detect significant degradation and failure of the RHR heat exchanger shell side internals due to erosion and erosion/corrosion. Visual inspection should be performed on the RHR heat exchanger shell side once per 10-year inspection interval.

If erosion and erosion/corrosion causes the RHR heat exchanger internals to become loose, then it is likely that vibration levels will increase. Vibration monitoring should be performed in accordance with either the plant's Preventive Maintenance Program or ASME Operation and Maintenance Code Program, whichever applies. Permanently installed vibration monitoring equipment would be the optimum; however, this is not a requirement to acquire the necessary data for analysis. Vibration monitoring should be performed on the RHR heat exchangers once per operating cycle and after major maintenance that changes the baseline vibration levels.

Therefore, if visual inspection is performed once per 10-year inspection interval and vibration data is obtained and trended on the RHR heat exchangers once per operating cycle (or other frequency determined to be adequate by plant-specific operating history) and following major maintenance activities, then erosion and erosion/corrosion of the RHR heat exchanger internals is effectively managed. 
For a heat exchanger tube side divider plate (i.e., carbon steel), visual inspections should be performed in accordance with the plant's Preventive Maintenance Program or ASME Operation and Maintenance Code Program, whichever applies. Visual inspection (see Section 5.2.3.3.1) is the most effective method to detect significant degradation and failure of the heat exchanger tube side divider plate due to erosion and erosion/corrosion. Visual inspection should be performed on each treated water heat exchanger once per 10-year inspection interval.

If erosion and erosion/corrosion causes the divider plate to become detached or otherwise broken such that cooling water flow bypasses the tubes, then the thermal capacity of the heat exchanger is diminished. Thermal performance monitoring should be performed in accordance with either the plant's Preventive Maintenance Program or ASME Operation and Maintenance Code Program, whichever applies. Section 5.2.3.2 describes several thermal performance monitoring methods that can be used to detect a failed heat exchanger divider plate. Thermal performance monitoring should be performed on each treated water heat exchanger in accordance with the requirements of Reference 5.9, not to exceed 10 years.

Therefore, if visual inspection is performed once per 10-year inspection interval and thermal performance data is obtained and trended on the treated water heat exchangers once per operating cycle (or other frequency determined to be adequate by plant-specific operating history), then erosion and erosion/corrosion of the heat exchanger tube side divider plate are effectively managed.

\subsubsection{Wear}

Detecting the presence of wear in the treated water system heat exchanger subcomponents is virtually impossible to achieve until such time as the subcomponent begins to exhibit abnormal behavior. Therefore, programs/techniques to effectively manage wear are generally performance based. Through heat exchanger performance monitoring and data acquisition, the trending of key operational parameters may provide sufficient information, prior to heat exchanger failure, so that planned maintenance activities can be conducted to repair/replace the affected heat exchanger subcomponent(s). Visual inspections and eddy current examinations are also helpful for wear detection in some situations. A combination of programs/techniques must be implemented to effectively manage wear.

For heat exchanger tubes in a treated water application, some form of vibration monitoring should be performed in accordance with either the plant's Preventive Maintenance Program or ASME Operation and Maintenance Code Program, whichever applies. Vibration monitoring is the most effective method to detect significant degradation and heat exchanger tube failure due to flow induced cyclic loading and wear. Permanently installed vibration monitoring equipment would be the optimum; however, this is not a requirement to acquire the necessary data for analysis. Section 5.2.3.3.4 describes three types of heat exchanger vibration measurement methods. Vibration monitoring should be performed on each treated water heat exchanger once per operating cycle and after major heat exchanger maintenance that changes the baseline vibration levels.

Eddy current examination methods performed in accordance with either the plant's Preventive Maintenance Program or ASME Operation and Maintenance Code Program, whichever 
applies, will identify and characterize flaws in non-ferromagnetic heat exchanger tubes. If the number or magnitude of cyclic loads experienced produces wear flaws (i.e., denting) in the tubes, then eddy current testing is effective at detecting these flaws. It is not necessary for these flaws to propagate through the tube wall for eddy current testing to be effective. Eddy current testing (see Section 5.2.3.3.3) should be performed on each treated water heat exchanger at least once each 10-year inspection interval and whenever the heat exchanger is open for maintenance activities.

If the number or magnitude of cyclic loading causes a heat exchanger tube to fail from wear such that through wall penetration occurs, then thermal performance monitoring and leak testing will effectively detect tube failures. Thermal performance monitoring and leak testing of heat exchangers is performed in accordance with either the plant's Preventive Maintenance or ASME Operation and Maintenance Code Program, whichever applies. Most heat exchangers are designed with enough heat transfer capacity margin such that a percentage of tubes can be plugged without impacting the ability of the heat exchanger to satisfy its required function. The thermal performance characteristics of the heat exchanger, however, decreases as the number of plugged tubes increases. Section 5.2.3.2 describes several thermal performance monitoring methods, and Section 5.2.3.3.2 describes several leak testing methods that can be used to detect failed heat exchanger tubes. Thermal performance monitoring should be performed on each treated water heat exchanger in accordance with the requirements of Reference 5.9, not to exceed 10 years. Leak testing should be performed on these heat exchangers whenever tube leaks are suspected.

Therefore, if vibration data and thermal performance data are obtained and trended on the treated water heat exchangers once per operating cycle (or other frequency determined to be adequate by plant-specific operating history) and following major maintenance activities; and eddy current testing and leak testing is performed to identify degraded and leaky tubes, then wear of heat exchanger tubes is effectively managed.

For a heat exchanger tube sheet in a treated water application, visual inspection should be performed in accordance with the plant's Preventive Maintenance Program or ASME Operation and Maintenance Code Program, whichever applies. Visual inspection (see Section 5.2.3.3.1) is the most effective method to detect significant degradation and heat exchanger tube sheet failure due to cyclic loading and wear. Visual inspection should be performed on each treated water heat exchanger once per 10-year inspection interval. From Section 4.3.2.2.6 in most instances, fatigue cracking occurs in the tube sheet ligaments (i.e., space between the holes). If ligament cracking propagates far enough, leakage across the tube sheet can be detected by thermal performance monitoring and leak testing methods as described in Sections 5.2.3.2 and 5.2.3.3.2, respectively. Thermal performance monitoring should be performed on each treated water heat exchanger in accordance with the requirements of Reference 5.9, not to exceed 10 years. Leak testing should be performed on these heat exchangers whenever tube sheet leaks are suspected.

Therefore, if visual inspection is performed once per 10-year inspection interval and thermal performance data obtained and trended once per operating cycle (or other frequency determined to be adequate by plant-specific operating history); and leak testing is performed to 
identify leaky tube sheet areas, then wear of the heat exchanger tube sheet is effectively managed.

\subsubsection{Fouling}

Detecting the presence of fouling in the treated water system heat exchanger subcomponents is virtually impossible to achieve until such time as the subcomponent begins to exhibit abnormai behavior. Therefore, programs/techniques to effectively manage fouling are generally performance based. Through heat exchanger performance monitoring and data acquisition, the trending of key operational parameters may provide sufficient information, prior to heat exchanger failure, so that planned maintenance activities can be conducted to repair/ replace the affected heat exchanger subcomponent(s). Visual inspections and eddy current examinations are also helpful for fouling detection in some situations. A combination of programs/techniques must be implemented to effectively manage fouling.

If fouling reaches the point where heat transfer capability begins to decrease from established levels, then thermal performance monitoring will effectively detect this degradation. Thermal performance monitoring of heat exchangers is performed in accordance with either the plant's Preventive Maintenance or ASME Operation and Maintenance Code Program, whichever applies. Most heat exchangers are designed with enough heat transfer capacity margin such that a certain amount of fouling can be tolerated without impacting the ability of the heat exchanger to satisfy its required function. The thermal performance characteristics of the heat exchanger, however, decreases as fouling of tubes increases. Section 5.2.3.2 describes several thermal performance monitoring methods that can be used to detect fouled heat exchanger tubes. Thermal performance monitoring should be performed on each treated water heat exchanger in accordance with the requirements of Reference 5.9 , not to exceed 10 years.

Eddy current examination methods performed in accordance with either the plant's Preventive Maintenance Program or ASME Operations and Maintenance Code Program, whichever applies, may identify and characterize fouling of individual non-ferromagnetic heat exchanger tubes. Eddy current testing (see Section 5.2.3.3.3) should be performed on each treated water heat exchanger at least once each 10-year inspection interval and whenever the heat exchanger is open for maintenance activities.

Therefore, if thermal performance data is obtained and trended on the treated water heat exchangers once per operating cycle (or other frequency determined to be adequate by plantspecific operating history), and eddy current testing is performed to identify the fouled and degraded tubes, then fouling of the heat exchanger tubes is effectively managed.

For a heat exchanger tube sheet in a treated water application, visual inspection should be performed in accordance with the plant's Preventive Maintenance Program or ASME Operation and Maintenance Code Program, whichever applies. Visual inspection (see Section 5.2.3.3.1) is the most effective method to detect significant degradation and heat exchanger tube sheet failure due to fouling and deposits. Visual inspection should be performed on each treated water heat exchanger once per 10-year inspection interval. If fouling propagates far enough across the tube sheet, the tubes may become plugged which can be detected by thermal performance monitoring methods as described in Section 5.2.3.2. Thermal performance 
monitoring should be performed on each treated water heat exchanger in aceordance with the requirements of Reference 5.9 , not to exceed 10 years.

Therefore, if visual inspection is performed once per lo-year inspection interval and thermal performance data obtained and trended once per operating cycle (or other frequency determinec to be adequate by plant-specific operating history), then fouling of the heat exchanger tube sheet is effectively managed.

For the heal exchanger shell and internals, waterbox/channel head/divider plate, and associated nozzles in treated water applications, visual inspections should be performed in ace rdance with the plant's Preventive Maintenance Program or ASME Operation and Maintenance Code Program, whichever applies. Visual inspection (see Section 5.2.3.3.1) is the most effective method to detect fouling of the heat exchanger shell and internals, waterbox/ channel head/divider plate, and associated nozzles. Visual inspection should be performed on each treated water heat exchanger once per 10-year inspection interval.

Therefore, if visual inspection is performed once per 10-year inspection interval on the treated water heat exchangers, then fouling of the shell and internals, waterbox/channel head/ divider plate, and associated nozzles is effectively managed.

\subsubsection{Closed Cooling Water System Heat Exchangers}

From Tables 3-5 and 3-6 (i.e., tube side and shell side fluids) the closed cooling water system heat exchangers discussed in this section are the (1) BWR plant-Drywell coolers, miscellaneous oil coolers, RWCU System non-regenerative heat exchangers, SFP System heall exchangers, EDG System jacket water coolers, and the various CCW System heat exchangers, and (2) PWR plant-miscellaneous oil coolers, CVCS letdown and seal water heat exchangers, SFP System heat exchangers, EDG System jacket water coolers, RHR System heat exchangers, and the various CCW System heal exchangers. These heal exchangers were evaluated by subcomponent and the associated aging mechanisms, determined in Section 4.3, to be significant are:

- Tubes

- Mechanical Fatigue

- Microhiolngically Influenced Corrosion

- Wear

- Tube Sheets

-- Mechanical Fatigue

- General Corrosion

- Microbiologically Influened Corrosion

- Intergranular and Transgranular Stress Corrosion Cracking

- Wear 
- Shect/Nozzles/Internals

- Mechanical Fattigue

- General Corrosion

- Microbiologically Influeneed Corrosion

- Erosion and Erosion/Corrosion

- Waterbox/Channel Head/Divider Plate

- Mechanical Fatigue

- General Corrosion

- Microbiologic slly Influenced Corrosion

- Pressure Boundary Fasteners/Support Assembly

- None

The following programs/techniques are considered effective for detection and mitigation of these aging mechanisms.

- Mechanical Fatiguc

-- ASME Section XI Inservice Inspection and Testing

- Preventive Maimtenance

- ASME Operation and Maintenance Code

- General Corrosion

- ASME Section XI Inservice Inspection

- Preventive Maintenance

- ASME Operation and Maintenance Code

- Microbiologically Influenced Corrosion

- MIC Control Program

- Intergranular and Transgranular Stress Corrosion Cracking

- Preventive Maintenance

- ASME Operation and Maintenance code

- Wear

- Preventive Maintenance

- ASME Operation and Maintenance Code 
- Erosion and Lronion/Corrosion

- ASML: Section XI Inscrice Inspection and Testing

Preventive Maintenance

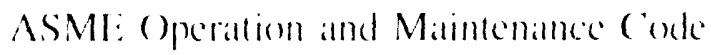

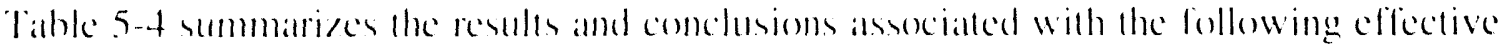
program/lechnigue evaluations.

\subsubsection{Mechanical Fatigue}

Delecting the presence of mechanical falligue in the closed cooling water system heall

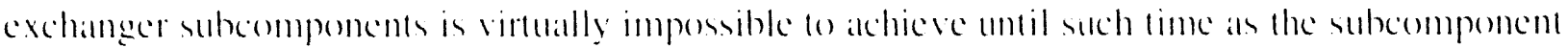
hegins to exhibit ahnormal beharion. Therefore, programs/lechniques to effectively manage mechanical fallgate are generally pertormance based. Through heal exchanger performance monitoring and datta acequistion, the trending of key eperational parameters maty provide

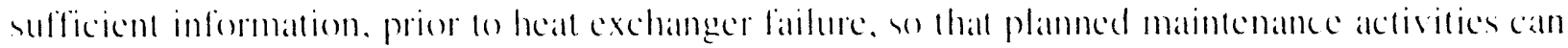
be condected to repair/replate the alfected heat exchanger subeomponentes). Vistal inspections

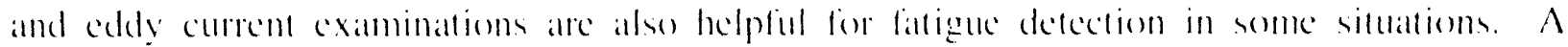
combination of programs/technique: must be implemented to effectively manage mechanical latiguc.

for heat exchanger tubes in a closed conling watce application, some form of vibation monitoring should be performed in aceordance with cither the plant? Preventive Maintenance Program or ASME (operation and Mantenance code Program, whichever applies. Vibration monitoring is the most effective method to detect significant degradation and heall exchanger tube

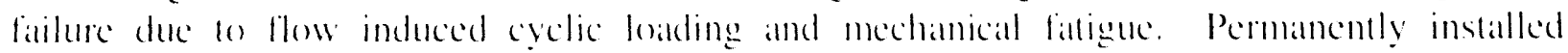
vibration monitoring equipment would be the optimum: however, this is not a reguirement to acyuire the necessaty data for analysis. Section 5.2.3.3.4 describes thee types of heall exchanger vibration measurement methods. Vibration monitoring should be performed on catch chesed cooling water heat exchanger one per operating eycic and affer major heal exchanger maintenance that changes the bascline vibation levels.

Eddy current examination methods pertormed in accordance with either the plant's Preventive Maintenance Program or ASME Operatton and Maintenance Code Program, whichever applies, will identify and characterize llaws in non-ferromagnetic heat exchanger lubes. If the number or magnitude of eyclie loads experiened produces fattgue flaws dice. fretting in the lubes, then eddy curremt lesting is erfective at detecting these llaws. It is not necessary for these Haws 10 propagate through the tube wall for eddy current kesting to be ellective. Eddy current testing (see Section 5.2.3.3.3) should be performed on each closed conting waller heall exchanger all least once each lo-year inspection interval and whenever the heall exchanger is open for maintenance activities.

If the number or magnitude of eyclic loading caluses the heall exchanger tube an fail from mechancal fatigue, such thall wall cracking oceurs, then thermal pertormance monitoring and leak kestung will effectively deted the tube lailures. Thermal performance monitoring and leak kesting of heal exchangers is performed in aceordance with cither the plant Preventive Matintenance or 
AGING MANAGEMENT GUIDELINE FOR HEAT EXCHANGERS

\begin{tabular}{|c|c|c|c|c|c|c|c|}
\hline \multirow[b]{2}{*}{$\begin{array}{l}\text { Heat Exchanger } \\
\text { Subcomponent }\end{array}$} & \multicolumn{4}{|c|}{ Conventional Programs/Techniques Commonly l'sed } & \multicolumn{3}{|c|}{ Non-Conventional Programs/Techniques Commonly lsed } \\
\hline & $\begin{array}{l}\text { AS.ME Sect. XI. } \\
\text { ISI. and IST }\end{array}$ & $\begin{array}{l}\text { ASME Operations and } \\
\text { Maintenance Standards }\end{array}$ & $\begin{array}{l}\text { Preventive } \\
\text { Maintenance }\end{array}$ & $\begin{array}{c}\text { MIC } \\
\text { Control }\end{array}$ & Lay-up & Operator Activities & Coatings Survey \\
\hline Tuber/Coils & & $\begin{array}{l}\text { Thernal Performance } \\
\text { Leah Testing } \\
\text { Eddy Current } \\
\text { Vihration Monituring }\end{array}$ & $\begin{array}{l}\text { Thermal Performance } \\
\text { Leeah Testing } \\
\text { Eddy Current } \\
\text { Vihration Monitoring }\end{array}$ & $\begin{array}{l}\text { Sampling } \\
\text { Treatment }\end{array}$ & Preservation & & \\
\hline Tuhe Sheet & & $\begin{array}{l}\text { Visual Inpection } \\
\text { Thermal Performance } \\
\text { Leah Texting }\end{array}$ & $\begin{array}{l}\text { Visual Inspection } \\
\text { Thermal Pertormance } \\
\text { Lecih Tenting }\end{array}$ & $\begin{array}{l}\text { Sampling } \\
\text { Treatment }\end{array}$ & Preservation & & \\
\hline $\begin{array}{l}\text { Shell/No/des } \\
\text { Internals }\end{array}$ & $\begin{array}{l}\text { Volumetric Examination } \\
\text { Surface Examination } \\
\text { Visual Examination } \\
\text { Presure Testing }\end{array}$ & $\begin{array}{l}\text { Visual Inspection } \\
\text { Vibration Monitoring }\end{array}$ & $\begin{array}{l}\text { Visual In pection } \\
\text { Vibration Monitorit? }\end{array}$ & $\begin{array}{l}\text { Sumpling } \\
\text { Treatment }\end{array}$ & Presertation & Inpections & Inspections \\
\hline $\begin{array}{l}\text { Waterhov/ } \\
\text { (hannel Head/ } \\
\text { Divider Plate }\end{array}$ & $\begin{array}{l}\text { Volumetric Exammation } \\
\text { Surface Examination } \\
\text { Visual Examination } \\
\text { Presure Teving }\end{array}$ & $\begin{array}{l}\text { Visual Inpection } \\
\text { Thermal Pertormance }\end{array}$ & $\begin{array}{l}\text { Vistal Inspection } \\
\text { Thermal Pertormance }\end{array}$ & $\begin{array}{l}\text { Sumpling } \\
\text { Treatmen: }\end{array}$ & Prevervation & Inpections & Inspections \\
\hline $\begin{array}{l}\text { Prewure Boundary } \\
\text { Fanteners/Support } \\
\text { Awembly }\end{array}$ & & & & & & & \\
\hline
\end{tabular}


ASME Operation and Maintenance code Program, whicherer applies. Most heall exchangers ane designed with heat transfer capacity margin such that a perentage of lubes can be plugged without impacting the ability of the heal exchanger 10 satisfy it required function. Thermal performance characteristics of the heall exchanger. hewever, decreases als the mumber of tubes that are plugged increases. Section 5.2.3.2 describes several thermal performance monitoring metheds and Section 5.2.3.3.2 describes several leats testing methods that can be used lo detect failed heall exchanger tubes. Thermal performanee monitoring shoukd be performed on each elosed conting water heat exchanger in aceordance with the reguirements of Reference 5.9. not 10 exced 10 years. Leak lesting should be performed on these heall exchangers whenerer lube leatis are suspected.

Therefore, if vibration dita and thermal pertormance datat are obtained and trended on the closed cooling water heal exchangers once per operatting eycle for other frequency determined to he adequate by plant specific operatting history), and eddy current kesting and leak lesting is performed to identify degraded and leaky tubes. Hen mechanicall fatlgue of the heall exchanger tubes is effectively mananed.

For a heal exchanger tube sheet in a closed cooling watler applicattion. vistral inspection should be performed in accordance with the plant 's Perentive Maintenance Program or ASML: Operation and Maintenance Code Program, whichever applies. Visual inspection lsec Section 5.2.3.3.1) is the most effective method to detect significant degradation and heat exchanger tube sheet failure due to cyclic loading and mechanical latigue. Vistal inspection should he performed on each closed cooling water heat exchanger once per lo-year inspection interval. From Section 4.3.2.2.2 in most instances, fatigue crateking oceurs in the tube sheet ligaments (i.e. space between the holes). If ligament cracking propagates far enough, leakage across the tube sheet can be detected by themal performance monitoring and leak testing methods as described in Section 5.2.3.2 and 5.2.3.3.2 respectively. Thermal performance monitoring should be performed on each closed cooling water heal exchanger in accordance with the requirements of Reference 5.9, not to exceed 10 years. Leak testing should he performed on these heall exchangers wh never tube sheet leaks are suspected.

Therefore, if visual inspection is performed once per lo-year inspection interval, and thermal performance data is obtained and trended onee per operating eycle (or all another frequency determined to be adequate by plant specific operating history), and leak lesting is performed to identify leaky tube sheet areas, then mechancial fatigue of the closed cooling watler heat exchanger tube sheet is effectively managed.

For a heat exchanger shell, waterbox/channel head, and nowes in a closed cooling waller application. volumetric, surface, and vistlal examinations and pressure testing should be performed in alecordance with the plant's ASMI: Section XI Inservice Inspection and Testing Program. The requtred examinations for (lass 2 heall exchangers (see Section 5.2.1.1) should be followed for these closed cooling water heat exchanger applications. These shell. Waterhox/ channel head, and nozke examinations are perlormed each f()-year inspection interval. The pressure tests are performed al least once each inspection period alt a test pressure equal to the nominal operating pressure during system operation. Either a hydrostatic pressure test or the requirements of ASME: Code Case $N-498$ is performed all or neall the end of ealch lo-yeall inspection interval. The heall exchanger shell/waterbox/ chamnel head. and nozzle exterior 


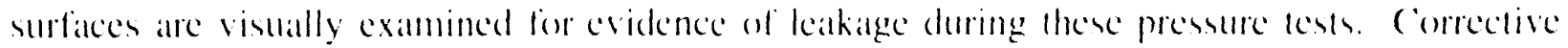
actions are implemented in aceordance with the rules and requiremente of ASML: Section XI cee Section 5.2.1.3).

Therefore, if volumetric, surface, and visual examinations atre performed on the heat exchanger shell, waterbox/channel head, and nozeles each l()-year inspection interval and pressure lesting is performed at least once each inspection period, then mechanical fattigte of the closed cooling water heal exchanger bell, waterbox/channel head, and novdes is effectively managed.

For heal exchanger stell side internals, visual inspections should be performed in accordance with the plant's Preventive Maintenince Program or ASML (Operation and Matintenance code Program, whichever applies. Vistlal inspection (sec Section 5.2.3.3.1) is the most effective methed 10 detect significant degradation and failure of the heat exchanger shell side internals dese to cyclic lateding and mechanical latigue. Vistal inspection should be performed on each closed cooling water heat exchanger once per f(1)-yeall inspection interval.

If mechanical falligue catuses the heal exchanger internals fo become loose, then it is likely that vibration levels will increase. Vibration monitoring should be performed in alecordance with either the plant's Preventive Maintenance Program or ASML: ()peration, and Maintenance code Program, whichever applies. Permanently installed vibation monitoring equipment would be the optimum, however, this is not a requirement to acyuire the necessary datta for analysis. Vibration monitoring should be performed on each closed conting water heal exchanger one per operating cycle and after major maintenanee that changes the bascline vibration levels.

The: ane, a visual inspection is performed once per lo-years inspection interval, and vibation datta is ohtained and trended on the closed cosoling water heal exchangers once per operating cycle for other frequency determined to be adequate by plant specifie operating history') and following major maintenance activities, then mechanical fattigue of the heall exchanger internals is effectively managed.

For a heal exchanger tube side divider plate, vistal inspections should be performed in accordance with the plants Preventive Maintenance Program or ASME (Operation and Maintenance code Program, whicherer applies. Visual inspection (see Section 5.2.3.3.1) is the most effective method 10 detect significant degradation and failure of the heal exchanger tube side divider plate dee to cyclic loading and mechanical fattgete. Visual imspection should be performed on each closed cooling watler heall exchanger once per lo-year inspection interval.

If mechanical fatigue causes the divider platte on become delached or otherwise broken such that cooling water flow bypasses the lubes, then thermal capacity of the heall exchanger is diminished. Thermal performance monitoring should be performed in accordance with either the plant's Preventive Maintenance Program or ASME: (Operatton and Matintenance code Program, whichever applies. Section 5.2.3.2 describes several thermal performance monitoring metheds that can be used to detect a lailed heat exchanger divider plate. Thermal performance monitoring should be performed on each closed cooling water heall exchanger in accordance with the requirements of Reference 5.9, not to exceed 10 years. 
Therefore, if visual inspection is performed onece per lo-yeall inspection interval and thermal performance data is obtained and trended on the closed cooling water heat exchangers once per operating eycle for other freguency determined to be adecuate by plant-specific operating history, then mechanical fattigue of the heat exchanger tube side divider plate and tube sheet is effectively managed.

\subsubsection{General Corrosion}

From Section 4.3.2. general corrosion (i.e., by derincification) of munte metal lube sheets and general corrosion (i.c.. uniform wastige) of carbon sted lube sheets, shell/norales/internals. and waterbox/channel heald/divider plate in closed cooling water applications mus be effectively managed.

For an ASME Class 2 heall exchanger shell, waterbox/channel head, and nordes in a closed cooling water application, volumetric. surface, and vistall examinatioms, and pressure testing should be pertormed. For the ASME (latss.3 heall exchanger shell, waterbox/channel head and noy/es in closed cooling water applicalloms, pressure kesting is an effective program. These examination are performed in aceordance with the plant A ASME Section XI Inservice Inspection and Testing Program (sece Sections 5.2.1.1 and 5.2.1.2). The examinations on ASMI: (lass 2 heall exchangers are performed catch l(t)-year inspection interval, and the pressure tesh on boih ASMI:

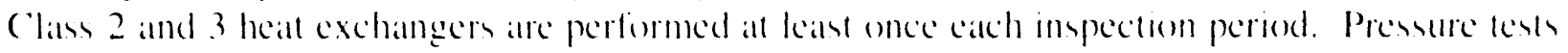
are performed at a value equal to the nominal operating pressure durmg system operation. Eather a hydrostatic pressure lest or the requirements of ASME cole case $N$-4os is pertormed on ASME: Class 2 heall exchangers and: a hydrostatic peessure test in performed on the ASML: Class 3 heall exchangers at or near the end of each lo-year imsection interval. The heat exchanger shell. wallerbox/channel head, and notele exterior surfaces are vistally examined for evidence of leakige during these pressure tests. Corrective actiom are implemented in accordance with the rules and requirements of ASME Section XI (see Section 5.2.1.3).

Therefore, if volumetric, surlace, and visual examinations are performed on the ASML: Class 2 heall exchanger shell. wallerbox/channel head, and moveles eadch lo-yeall inspection interval, and pressure testung is performed on hoth ASMI: Class 2 and 3 heat exchangers all leas once each imspectom period, then general corrosion of the heall exchanger shell, waterbox/channel head, and nozles in closed conling water applications is eflectively managed.

For carbon steel closed conling water heall exchanger shell side internah, visual inspections should be performed in aceordance with the plant s Preventive Matintenance Program or ASME Operation and Maintenance code Program, whichever applies. Visual inspection esee Section 5.2.3.3.1) is the most effective method to detect significant degradation and failure of the heat exchanger shell side internals due to general corrosion. Vistlal inspection should be

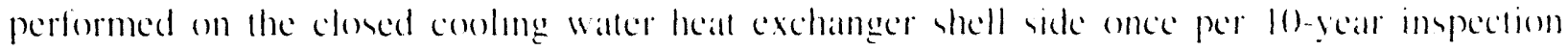
interval

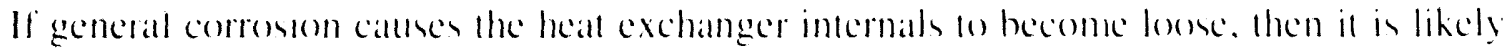
that vibattion levels will increase. Vibration monitoring should be performed in alceordance with

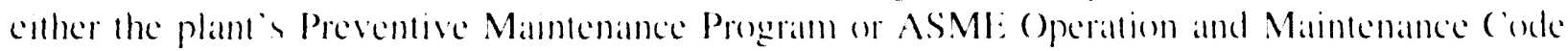
Program, whichever applies. Permanently installed vibratton monitoring equipment would be the 
optimum; however, this is not a requirement to acquire the necessary data for analysis. Vibration monitoring should be performed on the closed cooling water heat exchangers once per operating cycle and after major maintenance that changes the baseline vibration levels.

Therefore, if visual inspection is performed once per 10-year inspection interval and vibration data is obtained and trended on the closed cooling water heall exchangers once per operating cycle (or other frequency determined to be ade, ate by plant-specific operating history) and following major maintenance activities, then general corrosion of the closed cooling water heat exchanger internals is effectively managed.

For the carbon steel heat exchanger tube side divider plate (and carbon steel or munty metal tube sheets), visual inspections should be performed in accordance with the plant's Preventive Maintenance Program or ASME Operation and Maintenance Code Program, whichever applies. Visual inspection (see Section 5.2.3.3.1) is the most effective method to detect significant degradation and failure of the heat exchanger tube side divider plate and tube sheet due to general corrosion. Visual inspection should be performed on each closed cooling water heat exchanger once per 10-year inspection interval.

If general corrosion causes the divider plate to become detached or otherwise broken or the tube sheet to corrode through such that cooling water flow bypasses the tubes, then thermal capacity of the heal exchanger is diminished. Thermal performance monitoring should be performed in accordance with either the plant's Preventive Maintenance Program or ASME Operation and Maintenance Code Program, whichever applies. Section 5.2.3.2 describes several thermal performance monitoring methods that can be used to detect a failed heat exchanger divider plate or tube sheet. Thermal performance monitoring should be performed on each closed cooling water heat exchanger in accordance with the requirements of Reference 5.9, not to exceed 10 years.

Therefore, if vistal inspection is performed onee per lo-year inspection interval and thermal performance data is obtained and trended on the closed cooling water heal exchangers once per operating eycle (or other frequency deramined to be adequate hy plant-specific operating history), then general corrosion of the heat exchanger tube side divider plate and tube sheet is effectively managed.

\subsubsection{Microbiologically Influenced Corrosion}

From Section 4.3.2, MIC of heat exchanger tubes, lube sheets, shell/nozles/internats, and waterbox/channel head/divider plate subeomponents in closed ceoling water applications that are not treated with hiocides must be effectively managed regardless of material types.

Sampling of the closed cooling water fluid stream and immediately upstream and downstream from the heall exchanger should be performed quarterly in accordance with the plant's MIC Control Program. Sampling and analysis, and associated trending of the data, on a quarterly basis is sufficient 10 assess seasonal variations in the microbial content, oxygen level, and critical nutrients of the closed cooling water. Appropriate treatment methods, as delineated in Section 5.2.4.3, can then be implemented to effectively mitigate the effects of MIC. 
When the elosed cooling water heat exchanger is open for maintenance purposes or for visual inspection (i.e., once per l()-year inspection interval), solid samples of corrosion products, deposits, or tubercules should be removed and a detailed chemical and microbiological examination performed.

Additional visual examination and possibly metal samples of the under deposit area should also be performed in accordance with the plant's MIC Control Program. Analysis and trending of the solid sample and metallurgical data, if appropriate, may lead to better treatment methods that will mitigate the effects of MIC.

Therefore, if sampling and analysis of the closed cooling water upstream and downstream from the heat exchanger is performed quarterly for other frequency determined to be adequate by plant-specific operating history) and solid sampling and analysis is performed whenever the heat exchanger is open for maintenance or inspection. then MIC of the heat exchanger tubes, iube sheet, shell/nozzles/internals, and waterbox/channel head/divider plate in closed cooling water applications is effectively managed.

\subsubsection{Intergranular and Transgranular Stress Corrosion Cracking}

From Section 4.3.2.2.4, IGSCC and TGSCC of muntz metal tuhe sheets exposed to closed cooling water applications are required to be effectively managed.

For the muntz metal heat exchanger tube sheet in closed cooling water applications, visual inspection should be performed in accordance with the plant's Preventive Maintenance Program or ASME Operation and Maintenance Code Program, whichever applies. Visual inspection (see Section 5.2.3.3.1) is the most effective method to detect significant degradation and heat exchanger tube sheet failure due to IGSCC and/or TGSCC. Visual inspection should be performed on each of these treated water heat exchangers once pe: 10-year inspection interval. If cracking propagates far enough, leakage across the tube sheet can be detected by thermal performance monitoring and leak testing methods as described in Sections 5.2.3.2 and 5.2.3.3.2, respectively. Thermal performance monitoring should be performed on each of these closed cooling water heat exchangers in accordance with the requirements of Reference 5.9, not to exced 10 years. Leak lesting should be performed on these heat exchangers whenever lube sheet leaks are suspected.

Therefore, if visual inspection is performed once per l()-year inspection interval, and thermal performance data is obtained and trended onee per operating cycle for at another frequency determined to be adequate by plant-specilic operating history), and leak testing is pertormed to identify leaky tuhe sheet areas, then IGSCC and TGSCC of the closed cooling water heal exchanger tube sheet is effectively managed.

\subsubsection{Wear}

Detecting the presence of wear in the closed cooling water system heat exchanger subcomponents is virtually impossible to achieve until such time as the subcomponent begins to exhibut abnormal behaver. Therefore, programs/techniques to effectively manage wear are generally performance hased. Through heal exchanger performance monitoring and data 
acquisition, the trending of key operational parameters may provide sufficient information, prior to heat exchanger failure, so that planned maintenance atetivities can be conducted fo repatir/replace the affected heal exchanger subcomponent(s). Visual inspections and eddy current examinations are also helpful for wear detection in some siluations. A combination of programs/lechniques must he implemented to effectively manage wear.

For heat exchanger tubes in a closed cooling water application, some form of vibattion monitoring should be performed in accordance with either the plant's Preventive Mantenance Program or ASME Operation and Maintenance Code Program, whichever applies. Vibration monitoring is the most effective method to detect significant degradation and heal exchanger tube lailure due fo flow induced eyclic loading and wear. Permanently installed vibration monitoring equipment would be the optimum; however, this is not a requirement to acquire the necessary dala for analysis. Section 5.2.3.3.4 describes three types of heat exchanger vibration measurement methods. Vibration monitoring should be performed on each closed cooling waller heat exchanger once per operating eycle and after major heat exchanger maintenance that changes the baseline vibration levels.

Eddy current examination methods performed in accordance with either the plants Preventive Maintenance Program or ASME Operation and Maintenance code Program, whichever applies, will identify and characterize flaws in non-ferromagnetic heal exchanger lubes. If the number or magnitude of eyclic loads experienced produces wear flaws (i.e., denting) in the lubes, then eddy current testing is effective al detecting these flaws. It is not necessary for these flaws to propagate through the tube wall for eddy current testing to be effective. Edely current testing (sec Section 5.2.3.3.3) should be performed on each closed cooling water heat exchanger all least once each 10-year inspection interval and whenever the heat exchanger is open for maintenance activities.

If the number of magnitude of eyclic kading caluses the heal exchanger tube to fail from wear such that through wall penetration occurs, then themal performance monitoring and leat testing will effectively detect the tube failures. Thermal performance monitoring and leak testing of heat exchangers is performed in accordance with either the plant's Preventive Maintenance or ASME: Operaltion and Maintenance Code Program, whichever applies. Most heall exchangers are designed with heat transfer capaleity margin stch that a pereentage of tubes can be plugged without impacting the ability of the heall exchanger to satisfy its reguired function. The thermal performance characteristics of the heall exchanger, however, decreases as the number of tubes that are plugged increases. Section 5.2.3.2 describes several themal performante monitoring methods, and Section 5.2.3.3.2 describes several leak lesting anethods that cain be wed lo deted lailed heat exchanger tubes. Thermal performance monitoring should be performed on each closed costing water heall exchanger in accordance with the requirements of Reference 5.9. non lo exceed 10 years. Leak testing should he performed on these heall exchangers whenever lube leaks are suspected.

Therefore, if vibration data and thermal performance datat are obtained and trended on the

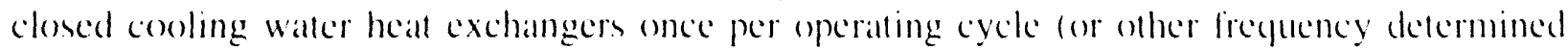
to be adequate by plant-specifie operating history) and following major maintenance activities: and eddy current lesting and leak lesting is performed to identify degraded and leaky lubes, then wear of the heat exchanger tubes is effectively managed. 
For a heat exchanger tube sheet in a closed cooling water application, visual inspection should be pertormed in aceordance with the plant's Preventive Maintenance Program or ASME Operation and Maintenance Code Program. whicherer applies. Vistlal inspection (see Section 5.2.3.3.1) is the most effective method 10 detect significant degradation and heal exchanger tube shee failure due to cyclic loading and wear. Visual inspection should be performed on each closed cooling water heat exchanger once per l()-year inspection interval. From Section 4.3.2.2.6 in most instances, cracking occurs in the tube sheed ligaments (i.e., spate between the holes). If ligament cracking propagates lat enough. leakage across the tube sheet can be detected by thermal performance monitoring and leak testing methods as described in Sections 5.2.3.2 and 5.2.3.3.2, respectively. Thermal performance monitoring should be performed on each closed cooling water heall exchanger in accordance with the requirements of Reference 5.9, not to exceed 10 years. Leak testing should be performed on these heal exchangers whenever tube sheet leaks are suspected.

Therefore, if vistal inspection is performed once per l(0-year inspection interval, and thermal performance data is obtained and trended once per operating eycle for at another frequency determined to be adequate by plant-specific operating history), and leak testing is performed to identify leaky lube sheet areas, then wear of the closed cooling water healt exchanger tube sheet is effectively managed.

\subsubsection{Erosion and Erosion/Corrosion}

From Section 4.3.2.3.5, erosion and erosion/corrosion must be effectively managed for the heal exchanger shell/noz/es/internals subcomponents made from carbon steel and exposed to closed cooling water on the shell side with fluid velocity that is greater than specified limits.

For an ASME Class 2 carbon steel heal exchanger shell and nozkles in a closed cooling water application. volumetric, surface, and visual examinations, and pressure testing should be performed. For the ASME Class 3 heat exchanger shell and nozkles in closed cooling water applications, pressure testing is an effective program. These examinations are performed in accordance with the plant's ASME Section XI Inservice Inspection and Testing Program (see Sections 5.2.1.1 and 5.2.1.2). The examinations on ASME Class 2 heat exchangers are performed each 10-year inspection interval, and the pressure tests on both ASME Class 2 and 3 heal exchangers are performed at least once each inspection period. Pressure tests are performed at a value equal to the nominal operating pressure during system operation. Either a hydrostatic pressure test or the regurements of ASME Code Case $\mathrm{N}-498$ is performed on ASME Clats 2 heat exchangers and; a hydrostatic pressure test is performed on the ASME Class 3 heat exchangers at or near the end of each 10 -year inspection interval. The healt exchanger shell and nozzle exterior surfates are visually examined for evidence of leakage during these pressure tests. Corrective actons are implemented in accordance with the rules and requirements of ASME Section XI (see Section 5.2.1.3).

Therefore, if solumetre, surface, and visual examinations are performed on the ASME Class 2 heal exchanger shell and nozhes each i()-year inspection interval and pressure testing is performed on both ASME Class 2 and 3 heat exchangers at least once each inspection period. then erosion and erosion/corrosion of the heat exchanger shell and nozoles in closed conling water applications is effectively managed. 
For carbon steel heat exchanger shell side internals in a closed cooling water application, visual inspections should be performed in accordance with the plant's Preventive Maintenance Program or ASME Operation and Maintenance Code Program, whichever applies. Visual inspection (see Section 5.2.3.3.1) is the most effective method to detect significant degradation and failure of the heat exchanger shell side internals due to erosion and crosion/ corrosion. Visual inspection should be performed on the heat exchanger shell side once per 10-year inspection interval.

If erosion and erosion/corrosion cause the heat exchanger internals to become loose, then it is likely that vibration levels will increase. Vibration monitoring should be performed in accordance with either the plant's Preventive Maintenance Program or ASME Operation and Maintenance Code Program, whichever applies. Permanently installed vibration monitoring equipment would be the optimum; however, this is not a requirement to acquire the necessary data for analysis. Vibration monitoring should be performed on the closed cooling water heat exchangers once per operating cycle and after major maintenance that changes the baseline vibration levels.

Therefore, if visual inspection is performed once per 10-year inspection interval, and vibration data is obtained and trended on the closed cooling water heat exchangers once per operating cycle (or at another frequency determined to be adequate by plant-specific operating history) and following major maintcitance activities, then crosion and erosion/corrosion of the closed cooling water heat exchanger internals is effectively managed.

\subsubsection{Lubricating Oil System Heat Exchangers}

From Tables 3-5 and 3-6 (i.e., tube side and shell side fluids), the lubricating oil system heat exchangers discussed in this section are the (1) BWR plant - HPCI System lubrication oil coolers, RCIC System lubrication oil coolers, EDG lubrication oil coolers, and miscellaneous oil coolers and (2) PWR plant EDG lubrication oil coolers and miscellaneous oil coolers. From these tables, the lubricating oil flows through the shell side of these heat exchangers. There are no cases where lubricating oil flows through the tubes. These heat exchangers were evaluated by subcomponent, and the associated aging mechanisms, determined in Section 4.3 , to be significant are:

- Tubes

- Mechanical Fatigue

- Wear

- Fouling

- Tube Sheets

- Mechanical Fatigue

- Wear

- Fouling 
- Shell/Nozzles/Internals

- Mechanical Fatigue

- Fouling

- Waterbox/Channel Head/Divider Plate

- Mechanical Fatigue

- Pressure Boundary Fasteners/Support Assembly

- None

The following programs/techniques are considered effective for detection and mitigation of these aging mechanisms:

- Mechanical Fatigue

- ASME Section XI Inservice Inspection and Testing

- Preventive Maintenance

- ASME Operation and Maintenance Code

- Wear

- Preventive Maintenance

- ASME Operation and Maintenance Code

- Fouling

- Preventive Maintenance

-- ASME Operation and Maintenance Code

Table 5-5 summarizes the results and conclusions associated with the following effective program/technique evaluations.

\subsubsection{Mechanical Fatigue}

Detecting the presence of mechanical fatigue in the lubrication oil system heat exchanger subcomponents is virtually impossible to achieve until such time as the subcomponent begins to exhibit abnormal behavior. Therefore, programs/techniques to effectively manage mechanical fatigue are generally performance based. Through heat exchanger performance monitoring and data acquisition, the trending of key operational parameters may provide sufficient information, prior to heat exchanger failure, so that planned maintenance activities can be conducted to repair/ replace the affected heat exchanger subcomponent(s). Visual inspections and eddy current examinations are also helptul for fatigue detection in some situations. A combination of programs/techniques must be implemented to effectively manage mechanical fatigue of these heat exchanger components. 


\section{AGING MANAGEMENT GUIDELINE FOR HEAT EXCHANGERS}

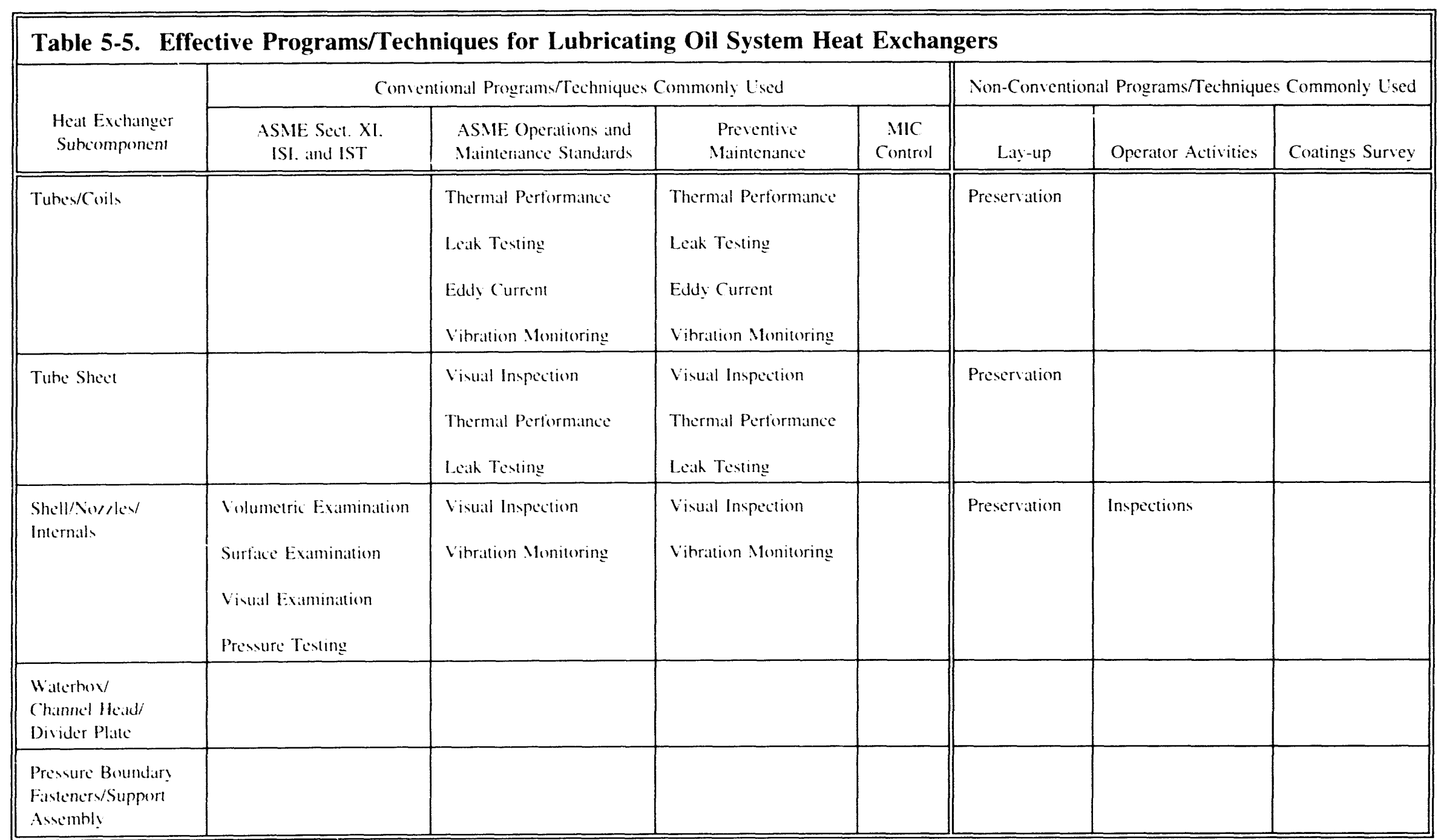


For heat exchanger lubes in a lubrication oil application, some form of vibration monitoring should be performed in aceordance with either the plant's Preventive Maintenance Program or ASME Operation and Maintenance Code Program, whichever applies. Vibration monitoring is the most effective method to detect significant degradation and heat exchanger tube failure due to flow induced cyclic loading and mechanical fattigue. Permanently installed vibration monitoring equipment would be the optimum; however, this is not a requirement to acquire the necessary data for analysis. Section 5.2.3.3.4 describes three types of heat exchanger vibration measurement methods. Vihration monitoring should be performed on each lubrication oil heat exchanger once per operating cycle and after major heat exchanger maintenance that changes the bascline vibration levels.

Eddy current examination methods performed in accordance with either the plant's Preventive Maintenance Program or ASME Operation and Maintenance Code Program, whichever applies, will identify and characterize flaws in non-ferromagnetic heal exchanger tuhes. If the number or magnitude of cyclic loads experienced produces wear flaws (i.e., fretting) in the tubes. then eddy current testing is effective at detecting these llaws. It is not necessary for these flaws to propagate through the tube wall for eddy current testing to be effective. Eddy current testing (see Section 5.2.3.3.3) should be performed on each lubrication oil heal exchanger at least once each 10-year inspection interval and whenever the heat exchanger is open for mantenance activities.

If the number or magnitude of cyclic loading causes the heat exchanger tube to fail from mechanical fatigue, such that throngh wall penetration occurs, then thermal performance monitoring and leak lesting will effectively detect the tube failures. Thermal performance monitoring and leak testing of heat exchangers is performed in accordance with either the plant's Preventive Maintenance or ASME Operation and Maintenance Code Program, whichever applies. Most heat exchangers are designed with heat transfer capacity margin such that a percentage of tuhes can be plugged without impacting the ability of the heat exchanger to satisfy its required function. Thermal performance characteristics of the heat exchanger. however, decreases as the number of tubes that are plugged increases. Section 5.2.3.2 describes several thermal performance monitoring methods, and Section 5.2.3.3.2 describes several leak testing methods that can be used to detect failed heat exchanger tuhes. Thermal performance monitoring should be performed on each lubrication oil heat exchanger in accordance with the requirements of Reference 5.9. not to exceed 10 years. Leak testing should be performed on these heal exchangers whenever tube leaks are suspected.

Therefore, if vibration data and thermal performance data are obtained and trended on the lubrication oil heat exchangers once per operating cycle (or other frequency determined to be adequate by plant-specific operating history) and following major maintenance activities, and eddy current testing and leak lesting is performed to identify degraded and saky tubes, then mechanical fatigue of the heat exchanger tubes is effectively managed.

For a heat exchanger tube sheet in a lubrication oil application, visual inspection should be performed in accordance with the plant's Preventive Maintenance Program or ASME Operation and Maintenance Code Program, whichever applies. Vistal inspection (see Section 5.2.3.3.1 1 is the most effective method to detect significant degradation and heat exchanger tube sheet fallure due to cyclic loading and mechanical fatigue. Visual inspection should be 
performed on each lubrication oil heat exchanger one per 10-year inspection interval. From Section 4.3.2.2.2 in most instances, cracking occurs in the tube sheet ligaments (i.e., space between the holes). If ligament cracking propagates far enough, leakage across the tube sheet can be detected by thermal performance monitoring and leak testing methods as described in Sections 5.2.3.2 and 5.2.3.3.2, respectively. Thermal performance monitoring should be performed on each lubrication oil heat exchanger in accordance with the requirements of Reference 5.9, not to exceed 10 years. Leak testing should be performed on these heal exchangers whenever tube sheet leaks are suspected.

Therefore, if visual inspection is performed once per 10-year inspection interval and thermal performance data obtained and trended once per operating cycle (or other frequency determined to be adequate by plant-specific operating history), and leak testing is performed to identify leaky tube sheet areas, then mechanic'sl fatigue of the lubrication oil heat exchanger tube sheet is effectively managed.

For ASME Class 2 heat exchanger shell and nozzles in a lubrication oil application, volumetric, surface, and visual examinations and pressure testing should be performed in accordance with the plant's ASME Section XI Inservice Inspection and Testing Program. The required examinations for Class 2 heal exchangers (see Section 5.2.1.1) should be followed for these lubrication oil heat exchanger applications. These shell and nozzle examinations alre performed each 10-year inspection interval. The pressure tests are performed at least once each inspection period at a test pressure equal to the nominal operating pressure during system operation. Either a hydrostatic pressure test or the requirements of ASME Code Case $\mathrm{N}$-498 is performed on ASME Class 2 heat exchangers at or near the end of each 1)-year inspection interval. The heat exchanger shell and nozzle exterior surfaces are visually examined for evidence of leakage during these pressure tests. Corrective actions are implemented in accordance with the rules and requirements of ASME Section XI (see Section 5.2.1.3).

Therefore, if volumetric, surface, and visual examinations are performed on the heal exchanger shell and nozzles each 10-year inspection interval; and pressure testing is performed at least once each inspection period, then mechanical fatigue of the lubrication oil heal exchanger shell and nozzles is effectively managed.

For the heat exchanger shell side internals, visual inspections should be performed in accordance with the plant's Preventive Maintenance Program or ASME Operation and Maintenance Code Program, whichever applies. Visual inspection (see Section 5.2.3.3.1) is the most effective method 10 detect significant degradation and failure of the heal exchanger shell side internals due to cyclic loading and mechanical fatigue. Visual inspection should be performed on each lubrication oil heat exchanger once per 10-year inspection interval.

If mechanical fatigue causes the heat exchanger internals to become loose, then it is likely that vibration levels will increase. Vibration monitoring should be performed in accordance with either the plant's Preventive Maintenance Program or ASME Operation, and Maintenance Code Program, whichever applies. Permanently installed vibration monitoring equipment would be the optimum, however, this is not a requirement to acquire the necessary data for analysis. Vibration monitoring should be performed on each lubrication oil heat exchanger once per operating cycle and after major maintenance that changes the baseline vibration levels. 
Therefore, if visual inspection is performed once per 10-year inspection interval and vibration data is obtained and trended on the lubrication oil heat exchangers once per operating cycle (or other frequency determined to be adequate by plant specific operating history) and following major maintenance activities, then mechanical fatigue of the heal exchanger internals is effectively managed.

From Tables 3-5 and 3-6, there are no heat exchangers with lubrication oil on the tube side of the heat exchanger. Therefore, the evaluation of mechanical fatigue, associated with the waterbox/channel head/divider plate, in these lubrication oil heal exchangers is discussed in Sections 5.4.2.1 (treated water), 5.4.3.1 (closed cooling water), and 5.4.5.1 (raw water). These applications are the cooling fluids for the various lubrication oil heat exchangers.

\subsubsection{Wear}

Detecting the presence of wear in the lubrication oil system heal exchanger subcomponents is virtually impossible to achieve until such time as the subemponent begins to exhibit abnormal behavior. Therefore, programs/techniques to effectively manage wear are generally performance based. Through heat exchanger performance monitoring and data acquisition, the trending of key operational parameters may provide sufficient information, prior to heat exchanger failure, so that planned maintenance activities can be conducted to repair/ replace the affected heat exchanger subcomponent(s). Vistal inspections and eddy current examinations are also helpful for wear detection in some situations. A combination of programs/ techniques must be implemented to effectively manage wear of lubrication oil system heal exchangers.

For heat exchanger tubes in a lubrication oil application, some form of vibration monitoring should be performed in accordance with either the plant's Preventive Maintenance Program or ASME Operation and Maintenance Code Program, whichever applies. Vibration monitoring is the most effective method to detect significant degradation and heal exchanger tube failure due to flow induced cyclic loading and wear. Permanently installed vibration monitoring equipment would be the optimum; however, this is not a requirement to acquire the necessary data for analysis. Section 5.2.3.3.4 describes three types of heat exchanger vibration measurement methods. Vibration monitoring should be performed on eatch lubrication oil heat exchanger once per operating cycle and after major heat exchanger maintenance that changes the baseline vibration levels.

Eddy current examination methods performed in aceordance with either the plant's Preventive Maintenance Program or ASME Operation and Maintenance Code Program, whichever applies, will identify and characterize flaws in non-ferromagnetic heat exchanger tubes. If the number or magnitude of cycle loads experienced produces wear flaws (i.e., denting) in the tubes, then eddy current testing is effective at detecting these flaws. It is not necessary for these flaws to propagate through the tube wall for eddy currem testing to be effective. Eddy current testing (see Section 5.2.3.3.3) should be performed on each lubrication oil heat exchanger at least once each 10-year inspection interval and whenever the heat exchanger is open for maintenance activitics. 
If the number or magnitude of cyclic loading causes the heat exchanger tube to fail from wear such that through wall penetration oceurs, then thermal performance monitoring and leak testing will effectively detect the tube failures. Thermal performance monitoring and leak testing of heat exchangers is performed in accordance with either the plant's Preventive Maintenance or ASME Operation and Maintenance Code Program, whichever applies. Most heall exchangers are designed with heall transfer capacity margin such that a perentage of tubes can he plugged without impacting the ability of the heat exchanger to satisfy its required function. The thermal performance characteristics of the heat exchanger, however, decreases as the number of tubes that are plugged increases. Section 5.2.3.2 describes several thermal performance monitoring methods, and Section 5.2.3.3.2 describes several leak testing methods that can be used to detect failed heat exchanger tubes. Thermal performance moritoring should be performed on each lubrication oil heal exchanger in accordance with the requirements of Reference 5.9, not to exceed 10 years. Leak lesting should be performed on these heat exchangers whenever tube leaks are suspected.

Therefore, if vibration data and thermal performance data are obtained and trended on the lubrication oil heat exchangers once per operating cycle for other frequency determined to be adequate by plant-specilic operating history) and following major maintenance activities, and eddy current testing and leak testing is performed to identify degraded and leaky tubes, then wear of the heat exchanger tubes is effectively managed.

For a heat exchanger tube sheet in a lubrication oil application, visual inspection should be performed in accordance with the plant's Preventive Maintenance Program or ASME Operation and Maintenance Code Program, whichever applies. Vistal inspection (see Section 5.2.3.3.1) is the most effective method to detect significant degradation and heat exchanger tube sheet failure due to cyclic loading and wear. Visual inspection should be performed on each lubrication oil heal exchanger once per 10-year inspection interval. From Section 4.3.2.2.6 in most instances, cracking occurs in the tube sheet ligaments (i.e., space between the holes). If ligament cracking propagates far enough, leakage across the tube sheet can be detected by thermal performance monitoring and leak testing methods as described in Sections 5.2.3.2 and 5.2 .3 .3 .2 , respectively. Thermal performance monitoring should be performed on each lubrication oil heat exchanger in accordance with the requirements of Reference 5.9, not to exceed 10 years. Leak testing should be performed on these heall exchangers whenever lube sheet leaks are suspected.

Therefore, if visual inspection is performed once per l(1)-year inspecion interval, and thermal performance data is oblained and trended once per operating cycle for at another frequency determined to be adequate by plant-specific operating history), and leak testing is performed 10 identify leaky tube sheet areas, then wear of the lubrication oil heat exchanger tube sheet is effectively managed.

\subsubsection{Fouling}

Detecting the presence of fouling in the lubrication oil system heat exchanger subcomponents is virtually impossible to achieve until such time as the subcomponent begins to exhibit abnormal behavior. Therefore, programs/techniques to effectively manage fouling are generally performance based. Through heat exchanger performance monitoring and data 
acquisition, the trending of key operational parameters may provide sufficient information, prior 10 heat exchanger failure, so that planned maintenance activities can be conducted to repair/ replace the affected heat exchanger subcomponent(s). Vistal inspections and eddy current examinations are also helpful for fouling detection in some situations. A combination of program/lechnicues must be implemented to effectively manage fouling of the lubrication oil healt exchangers.

If fouling reaches the point where heal transfer capability begins to decrease from estahlished levek, then thermal performance monitoring will effectively detect this degradation. Thermal performance monitoring of heal exchangers is performed in accordance with either the plant's Preventive Maintenance or ASME Operation and Maintenance Code Program, whichever applies. Most heal exchangers are designed with heat transfer capacity margin such that al certain amount of fouling can he tolerated without impacting the ability of the heat exchanger to satisfy its required function. The themal performance characteristics of the heall exchanger, however. decrease as fouling of tubes increases. Section 5.2.3.2 describes several thermal performance monitoring methods that can be used to deted fouled heat exchanger lubes. Thermal performance monitoring should be performed on each lubrication oil heal exchanger in accordance with the requirements of Reference 5.9. not 10 exceed 10 years.

Eddy current examination methods performed in accordance with either the plant's Preventive Maintenance Program or ASME Operations and Matintenance Code Proglam. whichever applies, may identily and characterize fouling of individual non-ferromagnetic heat exchanger lubes. Eddy current testing (see Section 5.2.3.3.3) should be performed on each lubrication oil heat exchanger al least once cach 10-year inspection interval and whenever the heal exchanger is open for maintenance atetivities.

Therefore, if thermal performance datat is ohtained and trended on the lubrication oil heall exchangers once per operating eycle for other frequency determined to be adequate by plantspecific operating history) and eddy current testing is performed to identify the fouled and degraded tubes, then fouling of the heal exchanger tubes is effectively managed.

From Tables 3-5 and 3-6, there are no heall exchangers with lubrication oil on the tube side of the heat exchanger. Therefore, the evaluation of fouling, associated with the tube sheet, in these lubrication oil heat exchangers is discussed in Sections 5.4.2.1 (treated watter), 5.4.3.1 (closed cooling water), and 5.4.5.1 (raw water). These applications are the cooling fluids for the various lubrication oil heal exchangers.

For heat exchanger shell/nozzles/internals in a lubrication oil application, visual inspection should be performed in accordance with the plant's Preventive Mantenance Program or ASML: Operation and Maintenance Code Program, whichever applies. Visual inspection (see Section 5.2.3.3.1) is the most effective method to detect fouling of the heat exchanger shell/ nozales/internals. Visual inspection should be performed on each lubrication oil heat exchanger once per lo-year inspection interval.

Therefore, if visual inspection is performed once per 10-year inspection interval on the lubrication oil heal exchangers, then fouling of the shell/nozales/internals is effectively managed. 


\subsubsection{Raw Water System Heat Exchangers}

From Tables 3-5 and 3-6 (i.e., lube side and shell side fluids), the raw water system heat exchangers discussed in this section are the (1) BWR plant - ECCS room coolers, various CCW System heat exchangers, RHR System heat exchangers, EDG System jacket water coolers, and EDG System lubrication oil coolers and (2) PWR plant - Containment System air coolers, various CCW System heal exchangers, EDG System jacket water coolers, and EDG System, lubrication oil coolers. These heat exchangers were evaluated by subcomponent, and the associated aging mechanisms determined in Section 4.3 to be significant are:

- Tubes

-.- Mechanical Fatigue

- General Corrosion

- Pilling Corrosion

- Microbiologically Influenced Corrosion

- Intergranular Stress Corrosion Cracking

- Erosion and Erosion/Corrosion

- Wear

- Fouling

- Tube Shects

- Mechanical Fatigue

- General Corrosion

- Pitting Corrosion

- Microbiologically Influenced Corrosion

- Intergranular and Transgranular Stress Corrosion Cracking

- Erosion and Erosion/Corrosion

- Wear

- Fouling

- Shell/Nozzles/Internals

- Mechanical Fatigue

_. Fouling

- Waterbox/Channel Head/Divider Plate

- Mechanical Fatigue

_- General Corrosion

- Pitting Corrosion

- Galvanic Corrosion

- Microbiologically Influenced Corrosion

- Intergranular Stress Corrosion Cracking

- Erosion and Erosion/Corrosion

- Fouling 
- Pressure Boundary Fasteners/Support Assembly

- Pitting Corrosion

The following programs/techniques are considered effective for detection and mitigation of these aging mechanisms.

- Mechanical Fattigue

- ASME Section XI Inservice Inspection and Testing

- Preventive Maintenance

- ASME Operation and Maintenance ciode

- General Corrosion

- ASME Section XI Inservice

- Preventive Maintenance

- ASME Operation and Maintenance Code

- Pitting Corrosion

- ASME Section XI Inservice Inspection and Testing

- Preventive Maintenance

-. ASME Operation and Maintenance Code

- Galvanic Corrosion

- ASME Section XI Inservice Inspection and Testing

- Preventive Maintenance

- ASME Operation and Maintenance Code

- Microbiologically Influenced Corrosion

- MIC Control Program

- Intergranular and Transgranular Stress Corrosion Cracking

- ASME Section XI Inservice Inspection and Testing

- Preventive Maintenance

- ASME Operation and Maintenance Code

- Erosion and Erosion/Corrosion

- ASME Section XI Inservice Inspection and Testing

- Preventive Maintenance

- ASME Operation and Maintenance Code 
- Wear

- Preventive Maintenance

- ASME Operation and Maintenance code

- Fouling

- Preventive Maintenance

- ASME (Operation and Maintenance code

Table 5-6 stummarizes the results and conclusions associated with the following effective program/lechnique evaluations.

\subsubsection{Mechanical Fatigue}

Delecting the presence of mechanical fatigue in the ratw water system heall exchanger subcomponents is virtually impossible to achieve until such time an the subeomponent begins 10 exhibit abnormal behavior. Therefore, programs/techniques of effectively manage mechanical fatigue are generally performance hased. Through heal exchanger performance monitoring and data acquisition, the trending of key operational parameters maly provide sufficient information. prior to heat exchanger failure, so that planned maintenance activitien can be condected to repair/ replace the affected heat exchanger subcomponent(s). Visual inspections and eddy current examinations are also helpful for fallgate detection in some situations. A combination of program. hechniques must be implemented to effectively manage mechanical falligue of (1) BWR plant - ECCS room coolers, various C CW System heal exchangers, RIIR System heal exchangers. EDG System jacket water coolers, and EDG System lubrication oil coolers and (2) PWR plant Contanment System air coolers. various (CW System heall exchangers. I:DC System jacked water conlers, and EDC System lubrication oil coolers.

For the beall exchanger wubes (i.e., stainless sted, admirally brass or copper-nickel) in rall water applications, some form of vibration monitoring should be performed in accordance with either the plant's Preventive Maintenance Program or ASME: ()peration and Matntenance code Program, whichever applies. Vibration monitoring is the most effective methes fo deted significant degradation and heal exchanger tube failure dec lo flow induced cyclic: loading and mechanical fattgue. Permanently installed vibration montoring equipment would be the optimum: however, this is not a requirement to acequire the necessitry data for analysis. Section 5.2.3.3.4 describes three types of heat exchanger vibration measurement methods. Vibration monitoring should be pertormed on each raw water heat exchanger once per operatting eycle and after major heat exchanger maintenance that changes the baseline vibration levels.

Eddy current examination methods performed in accordance with either the plant's Preventive Maintenance Program or ASME: Operation and Maintenance Code Program, whichever apples, will identify and characteries flaws in non-ferromagnetic heall exchanger lubes. If the number or magnitude of eyclic loads experienced produces fattigue flaws (i.e., fretting) in the lubes, then eddy current lesting is effective at detecting these flaws. It is not necessary for these flaws to propagate through the tube wall for eddy current testing to be effective. Eeddy current testing (see Section 5.2.3.3.3) should be performed on each raw water heat exchanger all least 


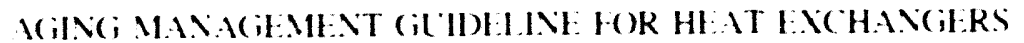

\begin{tabular}{|c|c|c|c|c|c|c|c|}
\hline \multirow[b]{2}{*}{ 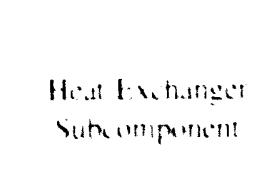 } & \multicolumn{4}{|c|}{ 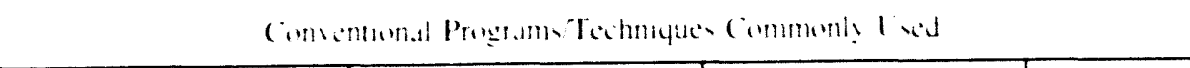 } & \multicolumn{3}{|c|}{ 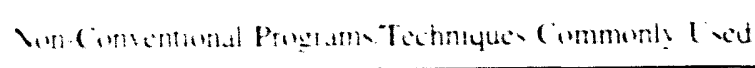 } \\
\hline & $\begin{array}{l}\text { Mive Sin Y. } \\
\text { ISt. and IST }\end{array}$ & 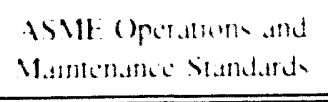 & $\begin{array}{l}\text { Proventwe } \\
\text { Mantenance }\end{array}$ & III & 1.tr up & Opcrater bomm & Coutm: Surbes \\
\hline Tuterink & & 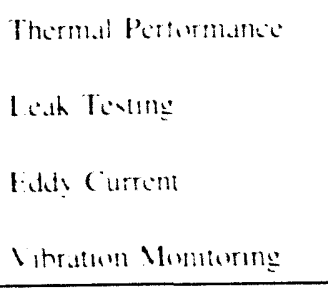 & 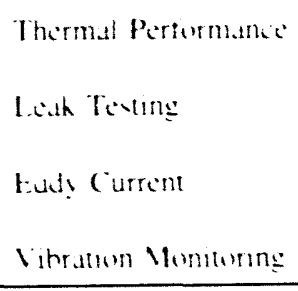 & $\begin{array}{l}\text { Sumping } \\
\text { Tratment }\end{array}$ & Prectratsuri & & \\
\hline luhe sheet & & 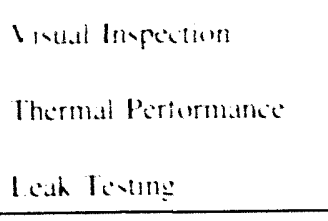 & 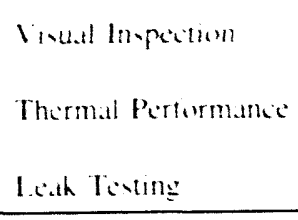 & $\begin{array}{l}\text { Sumping } \\
\text { Treatricent }\end{array}$ & Proverninm & & \\
\hline 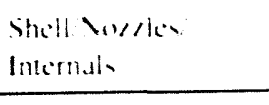 & & & & & & & \\
\hline 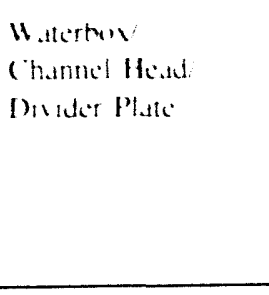 & 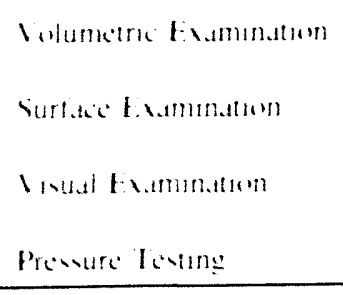 & $\begin{array}{l}\text { Sinul Inpeitun } \\
\text { Therm.l Pertirmanti }\end{array}$ & $\begin{array}{l}\text { Thual Impection } \\
\text { Thermat Pertermance }\end{array}$ & $\begin{array}{l}\text { S.mpluns } \\
\text { Treutment }\end{array}$ & Prowertation & Inpectum & Inpecition \\
\hline 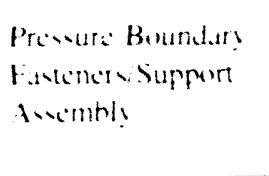 & 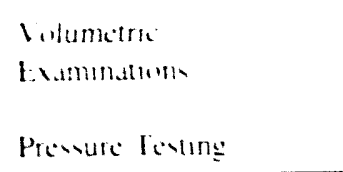 & & (indtung Protectum & & Prevervation & Inpections & Inspections \\
\hline
\end{tabular}


once each 10-year inspection interval and whenever the heal exchanger is open for maintenance activitics.

If the number or magnitude of cyclie loading causes the heat exchanger tube to fail from mechanical fatigue such that through wall penetration oceurs, then thermal performance monitoring and leak testing will effectively detect the tube lailures. Thermal performance monitoring and leak testing of heat exchangers is performed in accordance with either the plant's Preventive Maintenance or ASME: Operation and Maintenance (ode Program, whichever applies. Most heat exchangers are designed with heat transfer capacity margin such that a percentage of lubes can be plugged without impacting the ahility of the heall exchanger to sallisfy its reguired function. The thermal performance characteristics of the heal exchanger, however, decreases as the number of tubes that are plugged increases. Section 5.2.3.2 describes several thermal performance monitoring methods, and Section 5.2.3.3.2 describes several leak testing methods that can be used to detect failed heal exchanger tubes. Thermal performance monitoring should be performed on each raw water heat exchanger in alcerdance with the requirements of Reference 5.9, not 10 exceed 10 years. Leak testing should be performed on these heal exchangers whenever tuhe leaks are suspected.

Therefore, if vibration datat and thermal performance datla are obtained and trended on the raw water heat exchangers once per operatting eycle for other frequency determined to be adequate by plant-specific operating history) and following major maintenance activities, and eddy current lesting and leak testing are performed to identify degraded and leaky tubes, then mechanical fattigue of the heal exchanger tuber is effectively managed.

For a heal exchanger tube sheet (i.e. stainless stecl. muntz metal, or carbon steel) in a raw water application, vistal inspection should be performed in accordance with the plant's Preventive Maintenance Program or ASME Operation and Maintenance Code Program, whichever applies. Visual inspection (see Section 5.2.3.3.1) is the most effective method to detect significant degradation and heat exchanger tube shee failure due to eyclic loading and mechanical fatigue. Visual inspection should be performed on cach raw water heat exchanger once per 10-year inspection interval. From Section 4.3.2.2.2 in most instances, fatigue cracking occurs in the tube sheet ligaments (i.e. space between the holes). If ligament cracking propagates far enough, leakage across the tube sheet can be detected by thermal performance monitoring and leak testing methods as described in Sections 5.2.3.2 and 5.2 3.3.3.2, respectively. Thermal performance monitoring should be performed on each raw water heall exchanger in accordance with the requirements of Reference 5.9, not to exceed 10 years. Leak testing should be performed on these heat exchangers whenever lube sheet leaks are suspected.

Therefore, if vistal inspection is performed once per 10-year inspection interval and thermal performance data is obtained and trended once per operating cycle for other frequency determined to be adequate by plant-specific operating history and leak lesting is performed to identify leaky tube sheet areas, then mechanical fatigue of the heall exchanger tube sheet is effectively managed.

For ASME Class 2 heal exchanger waterbox/channel head and norkles (i.e.. carbon steel) in a raw water application, volumetric, surfice, and visual examinations, and pressure testing should he performed. For the ASML ("lass 3 heal exchanger wallerbox/ channel head and nozzles 
in raw water applications, pressure testing is an effective program. These examinations are performed in accordance with the plant's ASME Section XI Inservice Inspection and 'Testing Program (see Sections 5.2.1.1 and 5.2.1.2). The examinations on ASML (lass 2 heal exchangers are performed each 1()-year inspection interval, and the pressure lests on both ASME (lass 2 and 3 heat exchangers are performed at least once each inspection period. Pressure lests are performed at a value equal to the nominal operating pressure during system operation. Either a hydrostatic pressure test or the requirements of ASML Code Case N-498 is performed on ASME Class 2 heal exchangers and; hydrostatic pressure testing is performed on the ASME ('latss 3 heal exchangers at or near the end of each $1($ )-year inspection interval. The heal exchanger waterbox/channel head and nozzle exterior surfaces are vistally examined for evidence of leak ange during these pressure tests. Corrective actions are implemented in accordance with the rules and requirements of ASME Section XI (see Section 5.2.1.3).

Therefore, if volumetric, surface, and vistal examinations are performed on the $A$ SME Class 2 heat exchanger waterbox/channel head and nozgles each 1 ()-year inspection interval and pressure testing is performed on both ASME Class 2 and 3 heat exchangers at leasl once cach inspection period, then mechanical fatigue of the heat exchanger waterbox/channel head and nozales in raw water applications is effectively managed.

From Tables 3-5 and 3-6, there are no heal exchangers with raw water on the shell side of the heal exchanger. Therefore, the evaluation of mechanical fatigue, associated with the shell/ nozzles/internals in these raw water heal exchangers is discussed in Sections 5.4.2.1 (treated water), 5.4.3.1 (closed cooling water), 5.4.4.1 (lubrication oil), and 5.4.6.1 (drywell/Reactor Building/containment atmosphere). These applications are the process fluids for the various raw water heat exchangers.

For a heat exchanger tube side divider plate (i.e., carbon steel), visual inspections should be performed in accordance with the plant's Preventive Maintenance Program or ASMI: Operation and Maintenance Code Program, whichever applies. Visual inspection (see Section 5.2.3.3.1) is the most effective method to detect significant degradation and failure of the heal exchanger tube side divider plate due to cyclic loading and mechanical fatigue. Visual inspection should be performed on each raw water heat exchanger once per l()-year inspection interval.

If mechanical fatigue causes the divider plate to become detached or otherwise broken such that cooling water flow bypasses the tubes, then thermal capacity of the heal exchanger is diminished. Thermal performance monitoring stould be performed in aceordance with either the plant's Preventive Maintenance Program or ASME Operation and Maintenance Code Program, whichever applies. Section 5.2.3.2 describes several thermal performance monitoring methods that can be used 10 detect a failed heal exchanger divider plate. Thermal performance monitoring should be performed on each raw water heat exchanger in accordance with the requirements of Reference 5.9, not to exceed 10 years.

Therefore, if visual inspection is performed once per l()-year inspection interval and thermal performance data is obtained and trended on the raw water heat exchangers once per operating cycle for other frequency determined to be adequate by plant-specilic operating history), then mechanical fattigue of the heat exchanger tube side divider plate and lube sheet is elfectuvely maniged. 


\subsubsection{General Corrosion}

From Section 4.3.2.1.3, gencral corrosion must be effectively managed for relatively thin (i.e., less than 1,270 $\mu \mathrm{m}$ [50 mil]) copper-nickel alloy or inhibited admiralty brats heat exchanger tubes that are exposed to cyclic operation in raw water applications.

Eddy current examination methods performed in accordance with either the plant's Preventive Maintenance Program or ASME Operation and Maintenance Code Program, whichever applies, will identify and characterize flaws in non-ferromagnetic heat exchanger tubes. If general corrosion produces flaws (i.e., uniform or non-uniform thinning) in the tubes, then eddy current testing is effective at detecting these flaws. It is not necessary for these flaws to propagate through the tube wall for eddy current testing to be effective. Eddy current testing (see Section 5.2.3.3.3) should be performed on each raw water heat exchanger at least once each 10-year inspection interval and whenever the heat exchanger is open for maintenance activities.

If general corrosion causes the heat exchanger tube to fail such that through wall penetration occurs, then thermal performance monitoring and leak testing will effectively detect the tube failures. Thermal performance monitoring and leak testing of heat exchangers is performed in accordance with either the plant's Preventive Maintenance or ASME Operation and Maintenance Code Program, whichever applies. Most heat exchangers are designed with heat transfer capacity margin such that a percentage of tubes can be plugged without impacting the ability of the heat exchanger to satisfy its required function. The thermal performance characteristics of the heat exchanger, however, decreases as the number of tubes that are plugged increases. Section 5.2.3.2 describes several thermal performance monitoring methods, and Section 5.2.3.3.2 describes several leak testing methods that can be used to detect failed heat exchanger tubes. Thermal performance monitoring should be performed on each raw water heat exchanger in accordance with the requirements of Reference 5.9, not to exceed 10 years. Leak testing should be performed on these heat exchangers whenever tube leaks are suspected.

Therefore, if thermal performance data is obtained and trended on the raw water heat exchangers once per operating cycle (or other frequency determined to be adequate by plantspecific operating history) and eddy current testing and leak testing is performed to identify degraded and leaky tubes, then general corrosion of the heat exchanger tubes is effectively managed.

From Section 4.3.2, general corrosion (i.e., by dezincification) of muntz metal tube sheets and general corrosion (i.e., uniform wastage) of carbon steel tube sheets and waterbox/channel head/divider plate in raw water applications must be effectively managed.

For ASME Class 2 heat exchanger waterbox/channel head and associated nozzles (i.e.. carbon steel) in a raw water application. volumetric, surface, and visual examinations, and pressure testung should be performed. For the ASME Class 3 heal exchanger waterbox/ channel head and associated nozzles in raw water applications, pressure testing is an effective program. These examinations are performed in accordance with the plant's ASME Section XI Inservice Inspection and Testing Program (see Sections 5.2.1.1 and 5.2.1.2). The examinations on ASME Class 2 heat exchangers are performed each 10-year inspection interval, and the pressure tests on both ASME Class 2 and 3 heat exchangers are performed at least once each inspection period. 
Pressure tests are performed at a value equal to the nominal operating pressure during system operation. Either a hydrostatic pressure test or the requirements of ASME Code Case N-498 is performed on ASME Class 2 heat exchangers and; hydrostatic pressure testing is performed on the ASME Class 3 heat exchangers at or near the end of each 10-year inspection interval. The heat exchanger waterbox/channel head and nozzle exterior surfaces are visually examined for evidence of leakage during these pressure tests. Corrective actions are implemented in accordance with the rules and requirements of ASME Section XI (see Section 5.2.1.3).

Therefore, if volumetric, surface, and visual examinations are performed on the ASME Class 2 heat exchanger waterbox/channel head and associated nozzles each 10-year inspection interval and pressure testing is performed on both ASME Class 2 and 3 heat exchangers at least once each inspection period, then general corrosion of the heat exchanger waterbox/channel head and nozzles in raw water applications is effectively managed.

For a carbon steel heal exchanger tuhe side divider plate and carbon steel or muntz metal tuhe sheets, visual inspections should he performed in accordance with the plant's Preventive Maintenance Program or ASME Operation and Maintenance Code Program, whichever applies. Vistal inspection (see Section 5.2.3.3.1) is the most effective method to detect significant degradation and failure of the heat exchanger tube side divider plate and tube sheet due to general corrosion. Visual inspection should be performed on the raw water heat exchanger shell side once per lo-year inspection interval.

If general corrosion causes the divider plate become detached or otherwise broken or the tube sheet to corrode through such that cooling water flow bypasses the tubes, then thermal capacity of the heat exchanger is diminished. Thermal performance monitoring should be performed in accordance with either the plant's Preventive Maintenance Program or ASME Operation and Maintenance Code Program, whichever applies. Section 5.2.3.2 describes several thermal performance monitoring methods that can be used to detect a failed heat exchanger divider plate or tube sheet. Thermal performance monitoring should be performed on each raw water heal exchanger in accordance with the requirements of Reference 5.9, not to exceed 10 years.

Therefore, if visual inspection is performed once per lo-year inspection interval and thermal performance data is obtained and trended on the raw water heat exchangers once per operating cycle for other frequency determined to be adequate by plant-specific operating history), then general corrosion of the heat exchanger tube side divider plate and tube sheet is effectively managed.

\subsubsection{Pitting Corrosion}

From Section 4.3.2.1.3, pitting corrosion must be effectively managed for thin (i.e., 89) to $2.415 \mu \mathrm{m}$ (35 1095 mil]) stainless steel, copper-nickel alloy, or inhibited admiralty brass heal exchanger tubes that are exposed to raw water applications.

Eddy current examination methods performed in accordance with either the plant's Preventive Maintenance Program or ASME Operation and Maintenance Code Program, whichever applies, will identify and characterize flaws in non-ferromagnetic heat exchanger tubes. If pitting 
corrosion produces flaws in the tubes, then eddy current testing is effective at detecting these flaws. It is not necessary for these flaws to propagate through the tube wall for eddy current testing to be effective. Eddy current testing (see Section 5.2.3.3.3) should be performed on each raw water heat exchanger at least once each 10-year inspection interval and whenever the heat exchanger is open for maintenance activities.

If pitting corrosion causes the heat exchanger tube to fail such that through wall penetration occurs, then thermal performance monitoring and leak testing will effectively detect the tube failures. Thermal performance monitoring and leak testing of heat exchangers is performed in accordance with either the plant's Preventive Maintenance or ASME Operation and Maintenance Code Program, whichever applies. Most heat exchangers are designed with heat transfer capacity margin such that a percentage of tubes can be plugged without impacting the ability of the heat exchanger to satisfy its required function. The thermal performance characteristics of the heat exchanger, however, decreases as the number of tubes that are plugged increases. Section 5.2.3.2 describes several thermal performance monitoring methods, and Section 5.2.3.3.2 describes several leak testing methods that can be used to detect failed heat exchanger tubes. Thermal performance monitoring should be performed on each raw water heat exchanger in accordance with the requirements of Reference 5.9, not to exceed 10 years. Leak testing should be performed on these heat exchangers whenever tube leaks are suspected.

Therefore, if thermal performance data is obtained and trended on the raw water heal exchangers once per operating cycle (or other frequency determined to be adequate by plantspecific operating history) and eddy current testing and leak testing is performed to identify degraded and leaky tubes, then pitting corrosion of the heat exchanger tubes is effectively managed.

From Section 4.3.2, pitting corrosion of muntz metal or carbon steel tube sheets and the carbon steel waterbox/channel head/divider plate in raw water applications must be effectively managed.

For ASME Class 2 heat exchanger waterbox/channel head and associated nozzles (i.e., carbon steel) in a raw water application, volumetric, surface, and visual examinations, and pressure testing should be performed. For the ASME Class 3 heat exchanger waterbox/ channel head and associated nozzles in raw water applications, pressure testing is an effective program. These examinations are performed in accordance with the plant's ASME Section XI Inservice Inspection and Testing Program (see Sections 5.2.1.1 and 5.2.1.2). The examinations on ASME Class 2 heat exchangers are performed each 10-year inspection interval, and the pressure tests on both ASME Class 2 and 3 heat exchangers are performed at least once each inspection period. Pressure tests are performed at a value equal to the nominal operating pressure during system operation. Either a hydrostatic pressure test or the requirements of ASME Code Case N-498 is performed on ASME Class 2 heat exchangers and; hydrostatic pressure testing is performed on the ASME Class 3 heat exchangers at or near the end of each 10-year inspection interval. The heat exchanger waterbox/channel head and nozzle exterior surfaces are visually examined for evidence of leakage during these pressure tests. Corrective actions are implemented in accordance with the rules and requirements of ASME Section XI (see Section 5.2.1.3). 
Therefore, if volumetric, surface, and visual examinations are performed on the ASME Class 2 heat exchanger waterbox/channel head and associated nozzles each 10-year inspection interval and pressure testing is performed on both ASME Class 2 and 3 heat exchangers at least once each inspection period, then pitting corrosion of the heat exchanger waterbox/channel head and nozzles in raw water applications is effectively managed.

For a carbon steel heat exchanger tube side divider plate and carbon steel or muntz metal tube sheets, visual inspections should be performed in accordance with the plant's Preventive Maintenance Program or ASME Operation and Maintenance Code Program, whichever applies. Visual inspection (see Section 5.2.3.3.1) is the most effective method to detect significant degradation and failure of the heat exchanger tube side divider plate and tube sheet due to pitting corrosion. Visual inspection should be performed on each raw water heat exchanger once per 10-year inspection interval.

If pitting corrosion causes the divider plate to become detached or otherwise broken or the tube sheet to corrode through such that cooling water flow bypasses the tubes, then thermal capacity of the heat exchanger is diminished. Thermal performance monitoring should be performed in accordance with either the plant's Preventive Maintenance Program or ASME Operation and Maintenance Code Program, whichever applies. Section 5.2.3.2 describes several thermal performance monitoring methods that can be used to detect a failed heat exchanger divider plate or tube sheet. Thermal performance monitoring should be performed on each raw water heat exchanger in accordance with the requiremenis of Reference 5.9 , not to exceed 10 years.

Therefore, if visual inspection is performed once per 10-year inspection interval and thermal performance data is obtained and trended on the raw water heat exchangers once per operating cycle (or other frequency determined to be adequate by plant-specific operating history), then pitting corrosion of the heat exchanger tube side divider plate and tube sheet is effectively managed.

From Section 4.3.2.5.3, pitting corrosion was determined to be a significant aging mechanism for the pressure boundary fasteners in raw water applications in the event of joint leakage.

Volumetric examination is performed on the heat exchanger pressure retaining bolts and studs greater than two inches in diameter. These examinations are performed each 10-year inspection interval in accordance with the plant's ASME Section XI Inservice Inspection and Testing Program for Class 2 heat exchangers. If pitting corrosion of these pressure boundary fasteners propagates long enough, the fastened joint will loosen and excessively leak fluid. Pressure tests are performed in accordance with the plant's ASME Section XI Inservice Inspection and Testing Program at least once each inspection period at a test pressure equal to the nominal operating pressure during system operation. Either a hydrostatic pressure test or the requirements of ASME Code Case $\mathrm{N}-498$ is performed on these ASME Class 2 heat exchangers at or near the end of each 10-year inspection interval. The heat exchanger pressure boundary joints and associated fasteners are visually examined for evidence of leakage during these pressure tests. Pitting corrosion of pressure boundary fasteners, regardless of shank diameter, will 
be detected and corrective actions implemented in accordance with the rules and requirements of ASME Section XI (see Section 5.2.1.3).

Therefore, if volumetric examinations are performed on bolts and studs greater than two inches in diameter each 10 -year inspection interval and pressure testing is performed at least once each inspection period on all raw water heat exchangers, then pitting corrosion of the pressure boundary fasteners is effectively managed.

To further mitigate the potential for pitting corrosion to oecur in pressure boundary fasteners, Preventive Maintenance Program procedures should contain requirements to coat the fasteners following installation with a lubricant or other approved corrosion protection coating.

\subsubsection{Galvanic Corrosion}

From Section 4.3.2.4.3, galvanic corrosion must be effectively managed for carbon and low alloy steel heat exchanger waterbox/channel head/divider plate subassemblics that are exposed to raw water and not fitted with sacrificial anodes or other form of cathodic protection system.

For ASME Class 2 heat exchanger waterbox/channel head and associated nozzles (i.c., carbon steel) in a raw water application, volumetric, surface, and visual examinations, and pressure testing should be performed. For the ASME Class 3 heal exchanger waterhox/channel head and associated nozzles in raw water applications, only pressure testing should be performed. These examinations are performed in accordance with the plant's ASME Section XI Inservice Inspection and Testing Program (see Sections 5.2.1.1 and 5.2.1.2). The examinations on ASME Class 2 and 3 heat exchangers are performed at least once each inspection period. Pressure tests are performed at a value equal to the nominal operating pressure during system operation. Either a hydrostatic pressure test or the requirements of ASME Code Case N-498 is performed on ASME Class 2 heat exchangers and; hydrostatic pressure testing is performed on the ASME Class 3 heat exchangers at or near the end of each 10-year inspection interval. The heat exchanger waterbox/channel head and nozzle exterior surfaces are visually examined for evidence of leakage during these pressure tests. Corrective action are implemented in aceordance with the rules and requirements of ASME Section XI (see Section 5.2.1.3).

Therefore, if volumetric, surface, and visual examinations are performed on the ASME: Class 2 heal exchanger waterbox/channel head and associated nozzles each l()-year inspection interval and pressure testing is performed on both ASME Class 2 and 3 heat exchangers at least once each inspection period, then galvanic corrosion of the heat exchanger waterbox/channel head and associated nozzles in raw water applications is effectively managed.

For the carbon steel heat exchanger tube side divider plate, vistal inspections should be performed in aceordance with the plant's Preventive Maintenance Program or ASME Operation and Maintenance Code Program, whichever applies. Visual inspection should be performed on each raw water heat exchanger once per 10 -year inspection interval.

If gatvanic corrosion causes the divider plate to become detached or otherwise broken such that cooling water flow bypasses the tubes, then thermal capacity of the heat exchanger is 
diminished. Thermal performance monitoring should be performed in accordance with either the

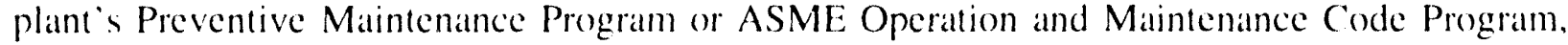
whichever applies. Section 5.2.3.2 describes several thermal performance monitoring methods that can be used to detect a failed heat exchanger divider plate. Thermal performance monitoring should be performed on each raw water heal exchanger in aceordance with the requirements of Reference 5.9, not to exceed 10 years.

Therefore, if visual inspection is performed once per 10-year inspection interval and thermal performance data is obtained and trended on the raw water heat exchangers once per operating cycle (or other frequency determined to be adequate by plant specific operating history), then galvanic corrosion of the heat exchanger tube side divider plate is effectively managed.

\subsubsection{Microbiologically Influenced Corrosion}

From Section 4.3.2. MIC of heat exchanger tubes, tuhe sheets, and waterbox/channel head/divider plate subcomponents in raw water applications must be effectively managed regardless of material types.

Sampling of the raw water at the source and immediately upstream and downstream from the heat exchanger shoukd he performed quarterly in accordance with the plant's MIC Control Program. Sampling and analysis, and associated trending of the data, on a quatrterly basis is sufficient to assess seasonal variations in the microbial content, oxygen level, and critical nutrients of the raw water. Appropriate treatment methods, as delineated in Section 5.2.4.3. can then be implemented to effectively mitigate the effects of MIC.

When the raw water heal exchanger is open for maintenance purposes or vistal inspection (i.e., once per 10-year inspection interval), solid samples of corrosion products, deposits, or whercules should be removed and a detailed chemical and microbiological examination performed. Additional visual examination and possibly metal samples of the under deposit area should also he performed in aceordance with the plant's MIC Control Program. Analysis and trending of the solid sample and metallurgical data, if appropriate. may lead to better treatment methods that will mitigate the effects of MIC.

Therefore, if sampling and analysis of the raw water upstream and downstream from the heat exchanger is performed quarterly cor other frequency determined wo be adequate by plantspecific operating history) and solid sampling and analysis is performed whenever the heall exchanger is open for maintenance or inspection, then MIC of the heal exchanger lubes, lube sheet, and waterbox/channel head/divider plate in raw water application is effectively managed.

\subsubsection{Intergranular and Transgranular Stress Corrosion Cracking}

IGSCC of stainless steel heat exchanger lubes (Section 4.3.2.1.4), lube sheets (Section 4.3.2.2.4), and waterbox/channel head/divider plate (Section 4.3.2.4.4) exposed lo law water applications are required to he effectively managed. Also. TeiSc ef of munte metal heat exchanger tube sheets (Section 4.3.2.2.t) exposed to raw water mus be effectively managed. 
Detecting the presence of IGSCC and TGSCC in the raw water system heat exchanger subcomponents is virtually impossible to achieve until such time as the subcomponent begins to exhibit abnormal behavior. Therefore, programs/techniques to effectively manage IGSCC and TGSCC are generally performance based. Through heat exchanger performance monitoring and data acquisition, the trending of key operational parameters may provide sufficient information. prior to heat exchanger failure, so that planned maintenance activities can be conducted to repair/ replace the affected heat exchanger subcomponent(s). Visual inspections and eddy current examinations are also helpful for IGSCC and TGSCC detection in some situations. A combination of program/techniques must be implemented to effectively manage IGSCC and TGSCC.

Eddy current examination methods performed in accordance with either the plant's Preventive Maintenance Program or ASME Operation and Maintenance Code Program, whichever applies, will identify and characterize flaws in non-ferromagnetic heat exchanger tubes. If IGSCC produces flaws (i.e., cracking) in the tubes, then eddy current testing is effective at detecting these flaws. It is not necessary for these flaws to propagate through the tube wall for eddy current testing to be effective. Eddy current testing (see Section 5.2.3.3.3) should be performed on each raw water heat exchanger at least once each 10-year inspection interval and whenever the heat exchanger is open for maintenance activities.

If IGSCC causes the stainless steel heat exchanger tube to fail such that through wall cracking occurs, then thermal performance monitoring and leak testing will effectively detect the tube failures. Thermal performance monitoring and leak testing of heat exchangers is performed in accordance with either the plants Preventive Maintenance Program or ASME Operation and Maintenance Code Program, whichever applies. Most heat exchangers are designed with heat transfer capacity margin such that a percentage of tubes can be plugged without impacting the ability of the heat exchanger to satisfy its required function. The thermal performance characteristics of the heat exchanger, however, decreases as the number of tubes that are plugged increases. Section 5.2.3.2 describes several thermal performance monitoring methods and Section 5.2.3.3.2 describes several leak testing methods that can be used to detect failed heat exchanger tubes. Thermal performance monitoring should be performed on each raw water heat exchanger in accordance with the requirements of Reference 5.9, not to exceed 10 years. Leak testing should be performed on these heat exchangers whenever tube leaks are suspected.

Therefore, if thermal performance data is obtained and trended on the raw water heat exchangers once per operating cycle (or other frequency determined to be adequate by plant specific operating history) and eddy current testing and leak testing is performed to identify degraded and leaky tubes, then IGSCC of the stainless steel heat exchanger tubes is effectively managed.

For the stainless steel and muntz. metal heat exchanger tube sheet in raw water applications, visual inspection should be performed in accordance with the plant's Preventive Maintenance Program or ASME Operation and Maintenance Code Program, whichever applies. Visual inspection (see Section 5.2.3.3.1) is the most effective method to detect significant degradation and heat exchanger tube sheet failure due to IGSCC or TGSCC. Visual inspection should be performed on each raw water heat exchanger once per 10-year inspection interval. If cracking propagates far enough, leakage across the tube sheet can be detected by thermal 
performance monitoring and leak testing methods as described in Section 5.2.3.2 and 5.2.3.3.2 respectively. Thermal performance monitoring should be performed on each raw water heal exchanger in accordance with the requirements of Reference 5.9, not to exceed 10 years. Leak testing should be performed on these heat exchangers whenever tube sheet leaks are suspected.

Therefore, if visual inspection is performed once per 10-year inspection interval and thermal performance data is obtained and trended on the raw water heat exchangers once per operating cycle (or other frequency determined to he adequate by plant specific operating history) and leak testing is performed to identify leaky tube sheet areas, then IGSCC and TGSCC of the heat exchanger tube sheet is effectively managed.

For ASME Class 2 stainless steel heat exchanger waterbox/channel head and associated nozzles in a raw water application, volumetric, surface, and visual examinations and pressure testing should be performed in accordance with the plant's ASME Section XI Inservice Inspection and Testing. These waterbox/channel head and associated nozzle examinations are performed each 10-year inspection interval. Pressure tests on both ASME Class 2 and 3 heat exchangers are performed at least once each inspection period at a test pressure equal to the nominal operating pressure during system operation. Either a hydrostatic pressure test or the requirements of ASME Code Case $\mathrm{N}-498$ is performed on ASME Class 2 heat exchangers and: hydrostatic pressure testing is performed on the ASME Class 3 heat exchangers at or near the end of each 10-year inspection interval. The heat exchanger waterbox/channel head and nozzle exterior surfaces are visually examined for evidence of leakage during these pressure tests. Corrective action are implemented in accordance with rules and requirements of ASME Section XI (see Section 5.2.1.3).

Therefore, if volumetric, surface, and visual examinations are performed on the heat exchanger waterbox/channel head and associated nozzles each 10-year inspection interval, and pressure testing is performed at least once each inspection period, then IGSCC of the stainless steel raw water heat exchanger waterbox/channel head and associated nozzles is effectively managed.

For a stainless steel heat exchanger tube side divider plate, visual inspections should be performed in accordance with the plant's Preventive Maintenance Program or ASME Operation and Maintenance Code Program, whichever applies. Visual inspection (see Section 5.2.3.3.1) is the most effective method to detect significant degradation and failure of the heat exchanger tube side divider plate due to IGSCC. Visual inspection should be performed on each raw water heat exchanger once per 10-year inspection interval.

If ICSCC causes the divider plate to become detached or otherwise broken such that cooling water flow hypasses the tubes then thermal capacity of the heat exchanger is diminished. Thermal performance monitoring should he performed in accordance with either plant's Preventive Maintenance Program or ASME Operation and Maintenance Code Program, whichever applies. Section 5.2.3.2 describes several thermal performance monitoring methods that can be used 10 detect a failed heat exchanger divider plate. Thermal performance monitoring should be performed on each raw water heat exchanger in accordance with the requirements of Reference 5.9, not to exceed 10 years. 
Therefore, if visual inspection is performed once per 10-year inspection interval and thermal performance data is obtained and trended on the raw water heat exchanger once per operating cycle (or other frequency determined to be adequate by plant specific operalting history), then ICSSC of the stainless steel healt exchanger tube side divider plate is effectively managed.

\subsubsection{Erosion and Erosion/Corrosion}

From sections 4.3.2.1.5, 4.3.2.2.5, and 4.3.2.4.5, erosion and erosion/corrosion must be effectively managed for the following heal exchanger components subject to raw watler.

- Tubes made from admiralty hrass or copper nickel alloys.

- Tube sheets made from muntz metal or carbon steel.

- Waterbox/channel head/divider plate and associated nozales made from carbon sted.

Eddy current examination methods performed in accordance with either the plant's Preventive Maintenance Program or ASME Operation and Maintenance Code Program, whichever applies, will identify and characterize flaws in non-ferromagnetic heal exchanger lubes. If erosion and erosion/corrosion produces flaws in the tubes, then eddy current testing is effective at detecting these flaws. It is not necessary for these flaws to propagate through the tube wall for eddy current lesting to be effective. Eddy current testing (see Section 5.2.3.3.3) should be performed on each ratw water heat exchanger at katst once each 10 -year inspection interval and whenever the heal exchanger is open for maintenance activitles.

If erosion and erosion/corrosion causes the heal exchanger tube to fail such that through wall penetration occurs, then thermal performance monitoring and leak lesting will effectively detect the tube failures. Thermal performance monitoring and leak testing of heat exchangers is performed in alceordance with either the plant's Preventive Maintenance or ASML Operation and Maintenance code Program, whichever applies. Most heat exchangers are designed with heat transfer capacity margins such that a percentage of tubes can be plugged without impacting the ability of the heat exchanger 10 satisfy its required function. The thermal performance characteristics of the heat exchanger, however, decreases as the number if tubes that are plugged increases. Section 5.2.3.2 describes several thermal performance monitoring methods, and Section 5.2.3.3.2 describes several leak lesting methods that can be used to detect failed heal exchanger tubes. Thermal performance monitoring should be performed on each raw water heal exchanger in accordance with the requirements of Reference 5.9, not to exceed 10 years. Leak testing should be performed on these heal exchangers whenever tube leaks are suspected.

Therefore, if thermal performance data is obtained and trended on the raw water heal exchanger once per operating cycle (or other frequency determined to be adequate by plantspecific operating history) and eddy current lesting and leak testing are performed to identify degraded and leaky tubes, then erosion and erosion/corrosion of the heall exchanger tubes are effectively managed. 
for a heal exchanger lube sheed fi.e.. munte metal or carbon steel) in a raw waller application. visual inspection should be performed in accordance with the plant s Preventive Maintenance Program or ASMI: Operation and Maintenance Code Program, whichever applies. Vistal inspection (see Section 5.2.3.3.1) is the most effective method to detect significant degradation and heat exchanger tuhe shee failure due to erosion and erosion/corrosion. Visual inspection should be performed on each raw water heall exchanger once per 1()-year inspection interval. If erosion and erosion/corrosion propagates lat enough, leakage across the tube sheet can be delected by thermal performane monitoring and leak lesting methods described in Sections 5.2.3.2 and 5.2.3.3.2, respectively. Thermal performance monitoring should be performed on each raw water heall exchanger in alceordance with the requirements of Reference 5.9. not 10 exceed 10 years. Leak testing should be pertiomed on these heal exchangers whenever tube sheet leaks are suspected.

Therefore, if vistal inspection is performed once per lo-year inspection interval and thermal performance data obtained and trended once per operating cycle for other frequency determir.d to be adequate by plant-specilic operating history), and leak lesting is performed to identify leaky lube sheet areas, then erosion and erosion/corrosion of the heat exchanger lube sheet are effectively managed.

For ASML: Class 2 heal exchanger waterbox/channel head and associated nordes (i.e., carbon steel) in a raw water application, volumetric, surface, and vistal examinations, and pressure testing should be performed. For the ASML: Class 3 heall exchanger wallerbox/ channel head and associated noveles in raw water applications, pressure testing is an effective program. These examinations are performed in accordance with the plant's ASME Section XI Inservice Inspection and Testing Program (see Sections 5.2.1.1 and 5.2.1.2). The examinations on Class 2 heat exchangers are performed each 10-year inspection interval, and the pressure tests on both ASME Class 2 and 3 heal exchangers are performed all least once eatch inspection period. Pressure tests are performed at a value equal to the nominal operating pressure during system operation. Either a hydrostatic pressure test or the requirements of ASME Code Case N-498 is performed on ASME (lass 2 heat exchangers and: hydrostatic pressure testing is performed on the ASME Class 3 heal exchangers al or neall the end of each lo-year inspection interval. The heal exchanger waterbox/channel head and nozke exterior surfaces are vistally examined for evidence of leakage during these pressure tests. Corrective actions atre implemented in aceordance with the rules and requirements of ASME Section XI (see Section 5.2.1.3).

Therefore, if volumetric, surfice, and vistal examinations are performed on the ASME (lass 2 heal exchanger watterhox/channel head and associated nozles each 10-year inspection interval, and pressure testing is performed on both ASME Class 2 and 3 exchangers at least once each inspection period, then erosion and erosion/corrosion of the heat exchanger waterbox/channel head and associated nozales in raw water applicaltons are effectively managed.

For a heal exchanger tube side divider plate (i.e. carbon sted), visual inspections should be performed in accordanee with the plant's Preventive Maintenance Program or ASME Operatton and Mantenance (ocie Program, whichever applies. Vistal inspection (sec Section 5.2 .3 .3 .1 ) is the most effective method 10 deted significant degradation and failure of the heat exchanger tube side divider plate due to erosion and erosion/eorrosion. Vistal inspection should be performed on each raw water heat exchanger once per l()-year inspection interval. 
If erosion and erosion/corrosion causes the divider plate to hecome detached or otherwise broken such that cooling water flow bypasses the tubes, then thermal capacity of the healt exchanger is diminished. Thermal performance monitoring should be performed in accordance with either the plant's Preventive Maintenance Program or ASME Operation and Maintenance Code Program, whichever applies. Section 5.2.3.2 describes several thermal performance monitoring methods that can be used to detect a failed heat exchanger divider plate. Thermal performance monitoring should be performed on each raw water heat exchanger in accordance with the requirements of Reference 5.9. not to exceed 10 years.

Therefore, if visual inspection is performed once per 10-year inspection interval and thermal performance data is obtained and trended on the raw water heat exchangers once per operating cycle (or other frequency determined to he adequate by plant-specific operating history, then erosion and erosion/corrosion of the heat exchanger tube side divider plate are effectively managed.

\subsubsection{Wear}

Detecting the presence of wear in the raw water system heat exchanger subcomponents is virtually impossible to achieve until such time as the subcomponent begins to exhibit abnormal hehavior. Therefore, programs/techniques to effectively manage wear are generally performance based. Through heat exchanger performance monitoring and data acquisition, the trending of key operational parameters may provide sufficient information, prior to heat exchanger failure, so that planned maintenance activities can be conducted to repair/replace the affected heat exchanger subcomponent(s). Visual inspections and eddy current examinations are also helpful for wear detection in some situations. A combination of programs/techniques must be implemented to effectively manage wear.

For heat exchanger tubes in a raw water application, some form of vibration monitoring should be performed in accordance with either the plant's Preventive Maintenance Program or ASME Operation and Maintenance Code Program, whichever applies. Vibration monitoring is the most effective method to detect significant degradation and heat exchanger tube failure due to flow induced cyclic loading and wear. Permanently installed vibration monitoring equipment would be the optimum; however, this is not a requirement to acquire the necessary data for analysis. Section 5.2.3.3.4 describes three types of heat exchanger vibration measurement methods. Vibration monitoring should be performed on each raw water heat exchanger once per operating cycle and after major heat exchanger maintenance that changes the baseline vibration leveis.

Eddy current examination methods performed in accordance with either the plant's Preventive Maintenance Program or ASME Operation and Maintenance Code Program, whichever applies, will identify and characterize flaws in non-ferromagnetic heat exchanger tubes. If the number or magnitude of cyclic loads experienced produces wear flaws (i.e., denting) in the tubes, then eddy current testing is effective at detectung these flaws. It is not necessary for these flaws to propagate through the tube wall for eddy current testing to be effective. Eddy current testing (see Section 5.2.3.3.3) should be performed on each raw water heat exchanger at least once each 10-year inspection interval and whenever the heat exchanger is open for maintenance activities. 
If the number or magnitude of cyclic loading cause's the heall exchanger fube wo fail from wear such that through wall penetration oceurs, then thermal performance monitoring and leak testing will effectively detect the tuhe failure.s. Thermal performance monitoring and leak lesting of heat exchangers is performed in accordance with either the plant's Preventive Mainlenance or ASME Operation and Maintenance Code Program whichever applies. Most heat exchangers are designed with heat transfer capacity margin such that a percentage of tubes can be plugged without impacting the ability of the heal exchanger to satsisfy its required function. The thermal performance characleristies of the heal exchanger. however. decreases als the number of tubes that atre plugged increases. Section 5.2.3.2 describes several thermal performante monitoring methods, and Section 5.2.3.3.2 describes several leak testing methods that can be used to detect failed heal exchanger lubes. Thermal pertormance monitoring should be performed on each raw watter heat exchanger in aceordance with the requirements of Reference 5.9, not to exceed 10 years. leak lesting should he performed on these heall exchangers whenever tuhe leaks are suspected.

Therefore, if vibration data and thermal performance datat are obtained and trended on the raw waller heal exchangers once per operalting eycle for other frequency determined to be adequate by plant-specific operating history) and following major maintenanee activities and eddy current testing and leak lesting is performed to identify degraded and leaky tubes, then wear of the heal exchanger tubes is effectively managed.

For a heal exchanger tube sheet in a raw water application, visual inspection should be performed in accordance with the plant's Preventive Maintenance Program or ASME Operation and Maintenance Cole Program whichever applies. Visual inspection (see Section 5.2.3.3.1) is the most effective method to detect significant degradation and heat exchanger tube sheet failure due to cyclic loading and wear. Visual inspection should he performed on each raw water healt exchanger once per 10-year inspection interval. From Section 4.3.2.2.2 in most instances, cracking occurs in the tube sheet ligaments (i.e., space between the holes). If ligament cracking propagates far enough. leakage across the tube sheet can be detected by thermal performance monitoring and leak testing methods as described in Sections 5.2.3.2 and 5.2.3.3.2, respectively. Thermal performance monitoring should he performed on each raw water heal exchanger in accordance with the reyuirements of Reference 5.9, not to exceed 10 years. Leak testing should be performed on these heal exchangers whenever tube sheet leaks are suspected.

Therefore, if vistlal inspection is performed once per l()-year inspection interval, and thermal performance data is obtained and trended once per operating eycle (or all another frequency determined on be adequate by plant-specific operating history), and leak testing is performed to identify leaky tube sheet areas, then wear of the heal exchanger tube sheet is effectively managed.

\subsubsection{Fouling}

Detecting the presence of fouling in the raw water system heat exchanger subcomponents is virtually impossible to achieve until stlch time as the subcomponent hegins to exhibit abnormal hehavior. Therefore, programs/techniques 10 effectively manage fouling are generally performance based. Through heal exchanger performance monitoring and data aceuisition, the trending of key operational parameters mat provide sufficient information, prior to heat 
exchanger failure, so that planned maintenance activities can be conducted to repair/replace the affected heat exchanger subemponent(s). Vistal inspections and eddy current examinations are also helpful for fouling detection in some situations. A combination of programs/techniques must be implemented to effectively manage fouling.

If li uling reaches the point where heal transfer capability begins of decrease from established levels, then thermal performance monitoring will effectively detect this degradation. Thermal performance monitoring of heat exchangers is performed in accordance with either the plant's Preventive Maintenance or ASME: Operation and Maintenance Code Program, whichever applies. Most heat exchangers are designed with healt transfer capacily margin such that a certain amount of fouling can be tolerated without impacting the ability of the heal exchanger to sattisfy its required function. The thermal performance characteristics of the heat exchanger, however, decreases as fouling of tuhes increases. Section 5.2.3.2 describes several thermal performance monitoring methods that can be used to detect fouled heat exchanger tubes. Thermal performance monitoring should he performed on each raw water heat exchanger in alcerdance with the requirements of Reference 5.9, not to exceed 10 years.

Eddy current examination methods performed in accordance with either the plants Preventive Maintenance Program or ASME: Operations and Maintenance Code Program, whichever applies, may identify and characterize fouling of individual non-ferromagnetic healt exchanger tubes. Eddy current testing (see Section 5.2.3.3.3) should be performed on each raw walter heal exchanger at least once each 10-year inspection interval and whenever the healt exchanger is open for maintenance activities.

Therefore, if thermal performance data is obtained and trended on the raw water heat exchangers once per operating cycle (or other frequency determined to be adequate by plantspecific operating history) and eddy current testing is pertormed 10 identify the fouled and degraded tubes, then fouling of the heal exchanger tubes is effectively managed.

For a heal exchanger lube shee in a raw water applicaltion, vistal inspection should be performed in aceordanee with the plant's Preventive Maintenance Program or ASME (Operation and Maintenance Code Program, whichever applies. Visual inspection (see Section 5.2.3.3.1) is the most effective method lo detect significant degradation and heat exchanger tube shee failure due to fouling and deposits. Visual inspection should he performed on each raw waler healt exchanger once per 10-year inspection interval. If fouling propagates far enough across the tube sheet, the tubes may hecome plugged which can he detected hy thermal performance monitoring methods as described in Section 5.2.3.2. Thermal performance monitoring should be performed on each raw water heal exchanger in accordance with the requitements of Reference 5.9 , not 10 exceed 10 years.

Therefore, if visual inspection is performed once per lo-year inspection interval and thermal performance data obtanned and trended once per operating eycle for onther freyuency determined to be adequate by plant-specific operating history), then fouling of the heall exchanger tube sheet is effectively managed.

For heat exchanger waterhox/channel head/divider plate in a raw waller application. visual inspections should be performed in accordance with the plant s Preventive Matintenance Program 
Program or ASME Operalion and Maintenance Code Program, whichever applies. Visual inspection (see section 5.2.3.3.1) is the most effective method to detect fouling of the heat exchanger waterbox/channel head/divider plate. Vistal inspection should be performed on each raw water heall exchanger once per 10)-year inspection interval.

Therefore, if vistlal inspection is performed once per l()-year inspection interval on the raw water heal exchangers, then fouling of the waterhox/channel head/divider plate is effectively managed.

\subsubsection{Drywell/Reactor Building/Containment Atmospheric System Heat Exchangers}

From Tables 3-5 and 3-6 (i.e., lube side and shell side fluids) the drywell/reactor building/ containment atmospheric system heal exchangers discussed in this section are the (1) BWR plant - ECCS room coolers and the drywell coolers and (2) PWR plant - Containment System air coolers. From these tables, the building or room atmosphere (i.e., air or nitrogen) is directed by fan units across the tube outside surfaces with enther raw water or closed cooling water used as the cooling fluid on the inside of the tubes. The lubes are typically finned to achieve greater heat transfer capability (i.e., cooling) to the atmosphere. There ate no cases where the building or room atmosphere is directed through the lubes. These heat exchangers were evaluated by subcomponent and the associated aging mechanisms determined in Section 4.3 to be significant are:

- Tubes

-- Mechanical fattigue

- Erosion and Erosion/Corrosion

- Wear

- Tube Sheets

- Mechanical Fatigue

- Erosion and Erosion/Corrosion

-.. Wear

- Shell/Norzles/Internals

-... Mechanical Fatigue

- Waterbox/Channel Head/Divider Plate

- Mechanical Fatigue

- Erosion and Erosion/Corrosion

- Pressure Boundary Fasleners/Support Assembly

- None 
The following programs/techniques are considered effective for detection and mitigation of these aging mechanisms.

- Mechanical Fatigue

- Preventive Maintenance

- ASME Operation and Maintenance Code

- Erosion and Erosion/Corrosion

- Preventive Maintenance

- ASME Operation and Maintenance Code

- Wear

- Preventive Maintenance

- ASME Operation and Maintenance Code

Table 5-7 summarizes the results and conclusions associated with the following effective program/technique evaluations.

\subsubsection{Mechanical Fatigue}

Detecting the presence of mechanical fatigue in the system heat exchanger subcomponents is virtually impossible to achieve until such time as the subcomponent begins to exhibit abnormal behavior. Therefore, program/techniques to effectively manage mechanical fatigue are generally performance based. Through heat exchanger performance monitoring and data acquisition, the trending of key operational parameters may provide sufficient information. prior to heat exchanger failure, so that planned maintenance activities can be conducted to repair/replace the affected heat exchanger subcomponent(s). Visual inspection and eddy current examinations are also helpful for fatigue detection in some situations. A combination of programs/techniques must be implemented to effectively manage mechanical fatigue of (1) BWR plant-ECCS room coolers and the drywell coolers and (2) PWR plant Containment System air coolers.

For heat exchanger tube: (i.e., stainless steel, admiralty brass or copper-nickel) in an atmospheric application, some form of vibration monitoring should be performed in accordance with either the plant's Preventive Maintenance Program or ASME Opcration and Maintenance Code Program, whichever applies. Vibration monitoring is the most effective method to detect significant degradation and heat exchanger tube failure due to flow induced cyclic loading and mechanical fatigue. Permanently installed vibration monitoring equipment would be the optimum; however, this is not a requirement to acquire the necessary data for analysis. Section 5.2.3.3.4 describes three types of heat exchanger vibration measurement methods. Vibration monitoring should be performed on each atmospheric heat exchanger once per operating cycle and after major heat exchanger maintenance that changes the baseline vibration levels. 
AGING MANAGEMENT GUIDELINE FOR HEAT EXCHANGERS

\begin{tabular}{|c|c|c|c|c|c|c|c|}
\hline \multirow[b]{2}{*}{$\begin{array}{l}\text { Heat Exchanger } \\
\text { Sutxomponent }\end{array}$} & \multicolumn{4}{|c|}{ Conventional Programs/Techniques Commonly Lsed } & \multicolumn{3}{|c|}{ Non-Conventional Programs/Techniques Commonly Used } \\
\hline & $\begin{array}{l}\text { ASME Sect. XI. } \\
\text { ISI. and IST }\end{array}$ & $\begin{array}{l}\text { ASME Operations and } \\
\text { Maintenance Standards }\end{array}$ & $\begin{array}{l}\text { Preventive } \\
\text { Maintenance }\end{array}$ & $\begin{array}{l}\text { MIC } \\
\text { Control }\end{array}$ & Lay-up & Operator Activities & Coatings Survey \\
\hline Tuhes/Coils & & $\begin{array}{l}\text { Thermal Performance } \\
\text { Leak Testing } \\
\text { Eddy Current } \\
\text { V'ibration Monitoring }\end{array}$ & $\begin{array}{l}\text { Thermal Performance } \\
\text { Leak Testing } \\
\text { Eddy Current } \\
\text { Vibration Monitoring }\end{array}$ & & & & \\
\hline Tuhe Sheed & & $\begin{array}{l}\text { Visual Inspection } \\
\text { Thermal Performance } \\
\text { Leak Testing }\end{array}$ & $\begin{array}{l}\text { Visual Inspection } \\
\text { Thermal Performance } \\
\text { Leak Testing }\end{array}$ & & & & \\
\hline $\begin{array}{l}\text { Shell/xioles/ } \\
\text { Internals }\end{array}$ & & $\begin{array}{l}\text { Visual Inspection } \\
\text { Vibration Monitoring }\end{array}$ & $\begin{array}{l}\text { Visual Inspection } \\
\text { Vibration Monitoring }\end{array}$ & & & Inspections & \\
\hline $\begin{array}{l}\text { Waterboy/ } \\
\text { Channel Headi } \\
\text { Divider Plate }\end{array}$ & & & & & & & \\
\hline $\begin{array}{l}\text { Pressure Boundary } \\
\text { Fasteners/Support } \\
\text { Assembly }\end{array}$ & & & & & & & \\
\hline
\end{tabular}


Eddy current examination methods performed in accordance with either the plant's Preventive Maintenance Program or ASME Operation and Maintenance Code Program, whichever applies, will identify and characterize flaws in non-ferromagnetic heat exchanger tubes. If the number or magnitude of cyclic loads experienced produces fatigue flaws (i.e., fretting) in the tubes, then eddy current testing is effective at detecting these flaws. It is not necessary for these flaws to propagate through the tube wall for eddy current testing to be effective. Eddy current testing (see Section 5.2.3.3.3) should be performed on each heat exchanger at least once each 10-year inspection interval and whenever the heat exchanger is open for maintenance activities.

If the number or magnitude of cyclic loading causes the heat exchanger tube to fail from mechanical fatigue such that through wall penetration occurs, then thermal performance monitoring and leak testing will effectively detect the tube failures. Thermal performance monitoring and leak testing of heat exchangers is performed in accordance with either the plant's Preventive Maintenance or ASME Operation and Maintenance Code Program, whichever applies. Most heat exchangers are designed with heat transfer capacity margin such that a percentage of tuhes can be plugged without impacting the ability of the heat exchanger to satisfy its required function. The thermal performance characteristics of the heat exchanger, however, decreases as the number of tubes that are plugged increases. Section 5.2.3.3.2 describes several leak testing methods that can be used to detect failed heat exchanger tubes. Thermal performance monitoring should be performed on each atmospheric heat exchanger in accordance with the requirements of Reference 5.9. not to exceed 10 years. Leak testing should he performed on these heat exchangers whenever tube leaks are suspected.

Therefore, if vibration data and thermal performance data are obtained and trended on the atmospheric heat exchangers once per operating cycle (or other frequency determined to be adequate hy plant-specific operating history) and following major maintenance activities and eddy current testing and leak testing is performed to identify degraded and leaky tubes, then mechanical fatigue of the heat exchanger tubes is effectively managed.

For a heat exchanger tuhe sheet (i.e., stainless steel. munt\% metal, or carbon steel) in an atmospheric application where applicable, visual inspection should be performed in accordance with the plant's Preventive Maintenance Program or ASME Operation and Mantenance Code Program, whichever applies. Visual inspection (see Section 5.2.3.3.1) is the most effective method 10 detect significant degradation and heat exchanger tube sheet failure due to cyclic loading and mechanical fatigue. Visual inspection should be performed on each atmospheric heat exchanger once per 10-year inspection interval. From Section 4.3.2.2.2 in most instances, fattgue cracking occurs in the tube sheet ligaments (i.e., space between the holes). If ligament cracking propagates far enough. leakage across the tube sheet can be detected by thermal performance monitoring and leak testing methods as described in Sections 5.2.3.2 and 5.2.3.3.2. respectively. Thermal performance monitoring should be performed on each atmospheric heat exchanger in accordance with the requirements of Reference 5.9, not to exceed 10 years. Leak testing should he performed on these heat exchangers whenever lube sheet leaks are suspected.

Therefore, if visual inspection is performed once per l()-year inspection interval and thermal performance data is obtained and trended once per operating cycle (or other frequency determined to be adequate by plant-specific operating history) and leak testing is performed to 
identify leaky tube sheet areas, then mechanical faligue of the heat exchanger tube sheet is effectively managed.

From Tables 3-5 and 3-6 there are no heat exchangers with drywell/reactor building/ containment atmosphere on the tube side of the heat exchanger. Therefore, the evaluation of the mechanical fatigue, associated with the waterbox/channel head/divider plate in these atmospheric healt exchangers is discussed in Sections 5.4.3.1 (closed cooling water) and 5.4.5.1 (raw water).

For those atmospheric heal exchangers that have a shell/nozeles/internals (i.e., some do not, for example the ECC'S room coolers) visual inspection should be performed in accordance with the plant's Preventive Maintenance Program or ASME Operation and Maintenance Code Program, whichever applies. Vistlal inspection (see Section 5.2.3.3.1) is the most effective method to detect significant degradation and failure of the heat exchanger shell/nozrles/internals due to cyclic loading and mechanical fatigue.

If mechanical fatigue causes the heal exchanger internals to hecome loose, then it is likely that vibration levels will increase. Vihration monitoring should be performed in aceordance with either the plant's Preventive Maintenance Program or ASME Operation and Maintenance Code Program, whichever applies. Permanently installed vibration monitoring equipment would be the optimum; however, this is not a requirement to acquire the necessary data for analysis. Vibration monitoring should be performed on the almospheric heat exchangers that have a shell/norales/ internals once per operating cycle and after major maintenance that changes the baseline vibration levels.

Therefore, if visual inspection is performed once per l()-year inspection interval and vibration data is obtained and trended on the shell/nozdes/internals once per operating cycle cor other frequency determined to be adequate by plant-specific operating history) and following major maintenance activities, then mechanical fatigue of the atmospheric heat exchanger shell/ norzles/internals is effectively managed.

\subsubsection{Erosion and Erosion/Corrosion}

From Sections 4.3.2.1.5 erosion and erosion/corrosion must be effectively managed for admiralty metal heat exchanger lubes where the water vapor, condensed on the tube, is acidic and the air flow across the tube outside surfaces frequently changes direction.

From Tables 3-5 and 3-6 there are no heal exchangers with drywell/reactor huilding/ containment atmosphere on the tube side. Therefore, the evaluation of erosion and erosion/ corrosion associated with the waterbox/channel head/divider plate and tube sheet in these atmospheric heat exchangers is discussed in Sections 5.4.3.1 (closed cooling water) and 5.4.5.1 (raw watler).

Eddy current examination methods performed in accordance with either the plant's Preventuve Matuntenance Program or ASME Operation and Maintenance code Program, whichever applies, will identify and characterize flaws in non-ferromagnetic heall exchanger lubes. If erosion and erosion/corrosion produce flaws in the tubes, then eddy current testing is effective al detecting these flaws. It is not necessary for these flaws to propagate through the lube wall 
for eddy current testing to be effective. Eddy current testing (see Section 5.2.3.3.3) should be performed on each atmospheric heat exchanger at least once each 10-year inspection interval and whenever the heat exchanger is open for maintenance activities.

If erosion and erosion/corrosion cause the heat exchanger tube to fail such that through wall penetration occurs, then thermal performance monitoring and leak testing will effectively detect the tube failures. Thermal performance monitoring and leak testing of heat exchangers is performed in accordance with either the plant's Preventive Maintenance or ASME Operation and Maintenance Code Program, whichever applies. Most heat exchangers are designed with heat transfer capacity margin such that a percentage of tubes can be plugged without impacting the ability of the heat exchanger to satisfy its required function. The thermal performance characteristics of the heat exchanger, however, decreases as the number of tubes that are plugged increases. Section 5.2.3.2 describes several thermal performance monitoring methods, and Section 5.2.3.3.2 describes several leak testing methods that can be used to detect failed heat exchanger tubes. Thermal performance monitoring should be performed on each atmospheric heat exchanger in accordance with the requirements of Reference 5.9, not to exceed 10 years. Leak testing should be performed on these heat exchangers whenever tube leaks are suspected.

Therefore, if thermal performance data is obtained and trended on the almospheric heal exchangers once per operating cycle (or other frequency determined to be adequate by plantspecific operating history) and eddy current testing and leak testing are performed to identify degraded and leaky tubes, then erosion and erosion/corrosion of the heat exchanger tubes are effectively managed.

\subsubsection{Wear}

Detecting the presence of wear in the atmospheric system heal exchanger subcomponents is virtually impossible to achieve until such time as the subcomponent begins to exhibit abnormal behavior. Therefore, programs/techniques to effectively manage wear are generally performance based. Through heat exchanger performance monitoring and data acquisition, the trending of key operational parameters may provide sufficient information, prior to heat exchanger failure, so that planned maintenance activities can be conducted to repair/replace the affected heat exchanger subcomponent(s). Vistal inspections and eddy current examinations atre also helpful for weat detection in some situations. A combination of programs/techniques must be implemented to effectively manage wear.

For heat exchanger tubes in an atmospheric system application, some form of vibration monitoring should be performed in accordance with either the plant's Preventive Maintenance Program or ASME Operation and Maintenance Code Program, whichever applies. Vihration monitoring is the most effective method to detect significant degradation and heat exchanger tube failure due to flow induced cyclic loading and wear. Permanently installed vihration monitoring equipment would be the optimum; however, this is not a requirement to acquire the necessary data for analysis. Section 5.2.3.3.4 describes three types of heal exchanger vibration measurement methods. Vibration monitoring should be performed on each atmospheric system heat exchanger once per operating cycle and after major heat exchanger maintenance that changes the bascline vibration levels. 
Eddy current examination methods performed in accordance with either the plant's Preventive Maintenance Program or ASME Operation and Maintenance Code Program, whichever applies, will identify and characterize flaws in non-ferromagnetic heat exchanger tubes. If the number or magnitude of cyclic loads experienced produces wear flaws (i.e., denting) in the tubes, then eddy current testing is effective at detecting these flaws. It is not necessary for these flaws to propagate through the tube wall for eddy current testing to be effective. Eddy current testing (see Section 5.2.3.3.3) should be performed on each atmospheric system heat exchanger at least once each 10-year inspection interval and whenever the heat exchanger is open for maintenance activities.

If the number or magnitude of cyclic loading causes the heat exchanger tube to fail from wear, such that through wall penetration occurs, then thermal performance, monitoring, and leak testing will effectively detect the tube failures. Thermal performance monitoring and leak testing of heat exchangers is performed in accordance with either the plant's Preventive Maintenance Program or ASME Operation and Maintenance Code Program, whichever applies. Most heat exchangers are designed with heat transfer capacity margin such that a percentage of tubes can be plugged without impacting the ability of the heat exchanger to satisfy its required function. The thermal performance characteristics of the heat exchanger, however, decreases as the number of tubes that are plugged increases. Section 5.2.3.2 describes several thermal performance monitoring methods and Section 5.2.3.3.2 describes several leak testing methods that can be used to detect failed heat exchanger tubes. Thermal performance monitoring should be performed on each atmospheric system heat exchanger in accordance with the requirements of Reference 5.9, not to exceed 10 years. Leak testing should be performed on these heat exchangers whenever tube leaks are suspected.

Therefore, if vibration, data, and thermal performance data are obtained and trended on the atmospheric system heat exchangers once per operating cycle (or other frequency determined to be adequate by plant specific operating history) and following major maintenance activities; and eddy current testing and leak testing is performed to identify degraded and leaky test tubes, then wear of the heat exchanger tubes is effectively managed.

For a heat exchanger tube sheet in an atmospheric systen application, visual inspection should be performed in accordance with the plant's Preventive Maintenance Program or ASME Operation and Maintenance Code Program, whichever applies. Visual inspection (see Section 5.2.3.3.1) is the most effective method to detect significant degradation and heat exchanger tube sheet failure due to cyclic loading and wear. Visual inspection should be performed on each atmospheric system heat exchanger once per 10-year inspection interval. From Section 4.3.2.2.6 in most instances, cracking occurs in the tube sheet ligaments (i.e., space between the holes). If ligament cracking propagates far enough, leakage across the tube sheet can be detected by thermal performance testing monitoring and leak testing methods as described in Sections 5.2.3.2 and 5.2.3.3.2, respectively. Thermal performance monitoring should be performed on each atmospheric system heat exchanger in accordance with the requirements of Reference 5.9, not to exceed 10 years. Leak testing should be performed on these heat exchangers whenever tube sheet leaks are suspected.

Therefore, if visual inspection is performed once per 10-year inspection interval and thermal performance data is obtained and trended once per operating cycle (or other frequency 
determined to be adequate by plant specific operating history); and leak testing is performed to identify leaky tube sheet areas, then wear of the atmospheric system heat exchanger tube sheet is effectively managed.

\section{$5.5 \quad$ References}

5.1 Title 10, U.S. Code of Federal Regulations, 10 CFR Part 54, "Requirements for Renewal of Operating Licenses for Nuclear Power Plants," December 13. 1991.

5.2 Title 10, U.S. Code of Federal Regulations, 10 CFR Part 50.65, "Requirements for Monitoring the Effectiveness of Maintenance at Nuclear Power Plants," July 10. 1991

5.3 Title 10, U.S. Code of Federal Regulations, 10 CFR Part 50 Appendix B, "Quality Assurance Criteria for Nuclear Power Plants and Fuel Reprocessing Plants," 1992.

5.4 ASME Boiler and Pressure Vessel Code Section XI, "Rules for Inservice Inspection of Nuclear Power Plant Components," 199() Edition through and including the 1992 Addenda, December 31.1991.

5.5 ASME Section XI, Table IWC-25()()-1, Examination Categories C-A, C-B, C-C, C $-\mathrm{D}$, and $\mathrm{C}-\mathrm{H}$.

5.6 ASME Code Case N-498, "Alternative Rules for 10-Year Hydrostatic Pressure Testing for Class 1 and 2 Systems Section XI, Division 1," May 13, 1901.

5.7 ASME Section XI, Table IWD-25()()-1. Examination Categories D-A and D-B.

5.8 ASME OMa-S/G-1991 "Operation and Maintenance of Nuclear Power Plants: Part 11, Vibration Testing and Assessment of Heat Exchangers."

5.9 ASME OM-S/G-1994: "Standards and Guides for Operation and Maintenance of Nuclear Power Plants; Part 21, Inservice Performance Testing of Heat Exchangers in L.WR Plants," (in preparation).

5.10 Standards of Tubular Exchangers Manufacturers Association, TEMA, 1988.

5.11 EPRI Research Project RP2812-2, "Sourcebook for Microbiologically Influenced Corrosion in Nuclear Power Plants." 1988. 


\section{OTHER AGING MANAGEMENT CONSIDERATIONS}

The aging mechanisms affecting the various heat exchanger subeomponents in the seope of this AMG were discussed in Section 4. Section 5 evaluated each significant aging mechanism with respect to current maintenanee, inspection, lesting and trending programs/lechniques. For all of the significant aging mechanisms, it was determined that current programs/lechniques effectively detect and/or mitigate degradation and ensure long-term safe and reliable operation of these heal exchangers.

As discussed in Section 5.2.2, the ASME Code of Operation and Maintenance of Nuclear Power Plants (ASME OM (ode) relating to heat exchangers has not heen endorsed by the Boiler and Pressure Vessel committee of ASML, nor has it heen entered into the code of federal Regulation (I0) CFR 50.55a) as mandatory testing and inspection requirements. However, elements of this code effectively detect and/or mitigate aging and degradation occurring to the heat exchangers in the scope of this AMG. Since this code is not mandatory, some nucleall utilities may not be following the requirements contained within the ASME OM Code. If this is the case, then these utilities should consider upgrading or enhancing their preventive maintenance program to include elements of the ASME OM Code. 


\section{APPENDIX A}

DEFINITIONS[A.1]

accelerated aging artificial aging in which the simulation of natural aging approximates, in a short time, the aging effects of longer-term service conditions

acceptance criterion specified limit of a functional or condition indicator used to assess the ability of an $\operatorname{SSC}^{*}$ to perform its design function

age (noun) time from fabrication of an SSC to a stated time

age conditioning simulation of natural aging effects in an SSC by the application of any combination of artificial and natural aging

age-related degradation synonym for aging degradation

aging (noun) general process in which characteristics of an SSC gradually change with time or use

aging assessment evaluation of appropriate information for determining the effects of aging on the current and future ability of SSCs to function within acceptance criteria

aging degradation aging effects that could impair the ability of an SSC to function within acceptance criteria

aging effects net changes in characteristics of an SSC that occur with time or use and are due to aging mechanisms

aging management engineering, operations, and maintenance actions to control within acceptable limits aging degradation and wearout of SSCs

aging mechanism specific process that gradually changes characteristics of an SSC with time or use

artificial aging simulation of natural aging effects on SSCs by application of stressors representing plant pre-service and service conditions, but perhaps different in intensity, duration, and manner of application

breakdown synonym for complete failure

characteristic property or attribute of an SSC (such as shape, dimension, weight, condition indicator, functional indicator, performance or mechanical, chemical, or electrical property)

* SSC = system, structure, or component 


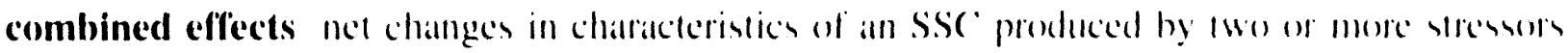
common cause failure lwo or more failures due lo a single calluse

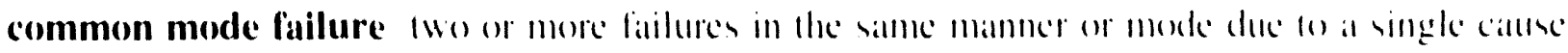
complete failure failure in which there is complete lous of function

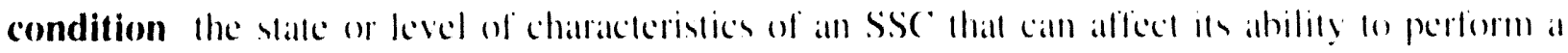
design function

condition surrounding physical stale or influence hall cann aflect an SSE'

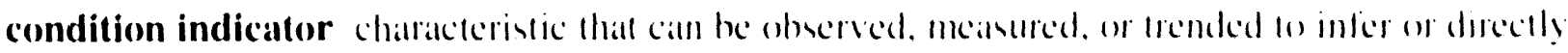

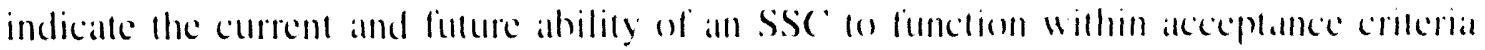

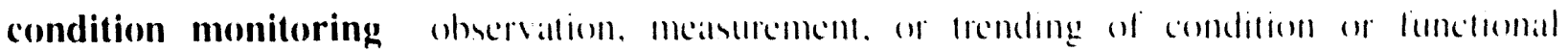

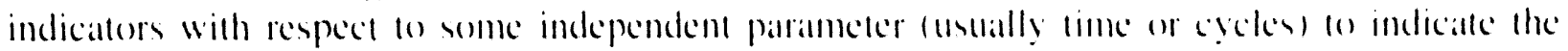
current and future ability of an SSC 10 function within atcecptance critcria

condition trending synonym lor condition monitoring

corrective maintenance actions that restore, by repair, werhatul, or replacement. dhe cappability

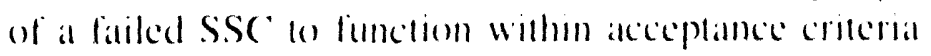

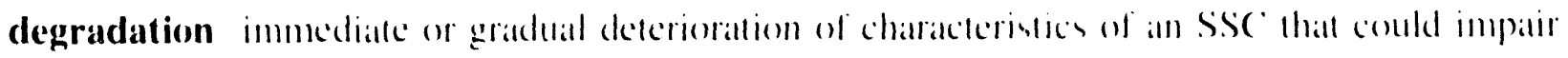
its ahility to function within acceptancec criteriat

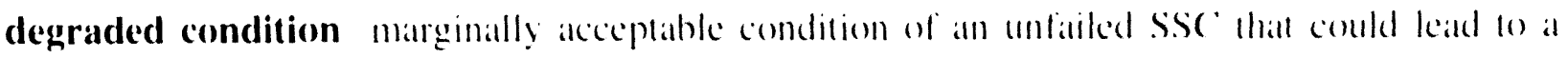
decision to perform planned maintenance

degraded failure lailure in which a functional indicattor des not meel an acceptance criterion. but design function is mot completely loul

design basis conditions syonnym for design conditions

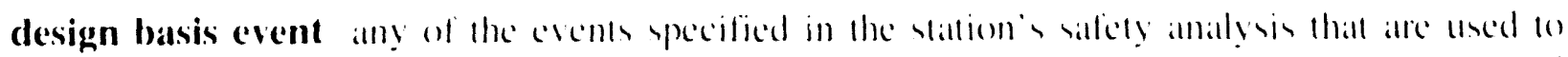

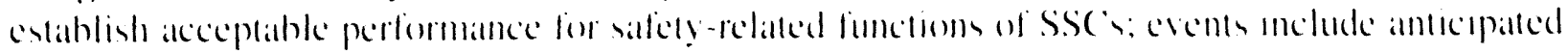
tramsients, dengen hasis atcidemese external events, and nattural phenomenal

design basis event conditions service condition produced by design baris evemls

design basis event stressor stessor that sems from design hasis events and can produce

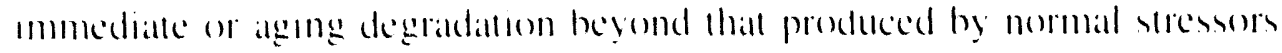

design conditions ypecified service conditions used to establish the specilicattions of an S.Se (generally meducter matgen of comservatism beyond expected servece conditions) 


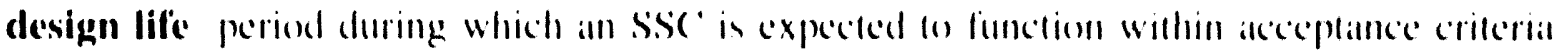
design service conditions synonym for design conditions

deterioration synonym for degradation

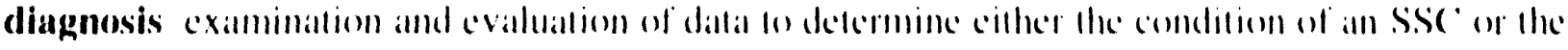
calluses of the condition

diagnostic evaluation synonym for diagnosis

environmental conditions ambicont physical stales surrounding an SSC'

crror-induced aging degradation aging degradation produced hy error-indaced conditions

error-induced conditions anderse presenvice or service conditions produced by design. fabricattion, installattion, operattion, or matntentunce coroms

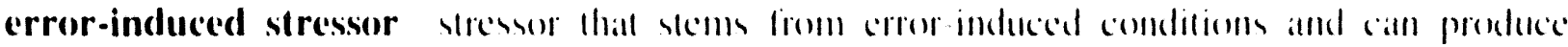

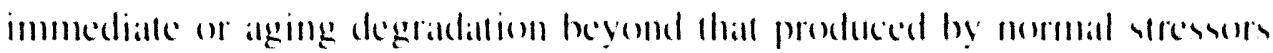

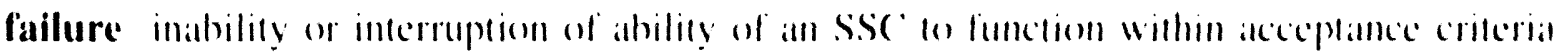

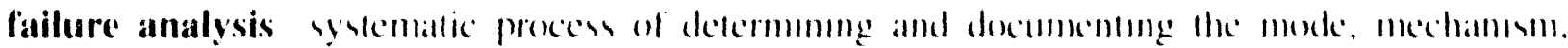

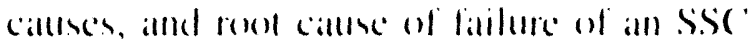

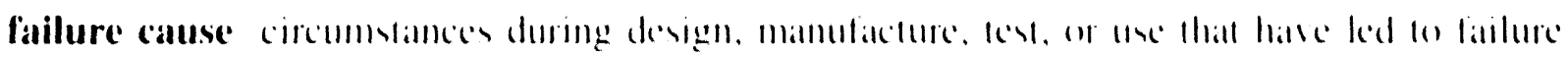

\section{failure evaluation synomyum lon failure analysis}

failure mechanism phỵicial process haul resuls in finlure

failure mode the manner or state in which all SSS' fails

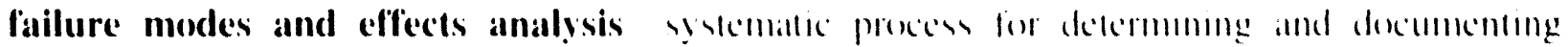

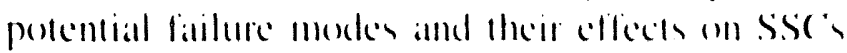

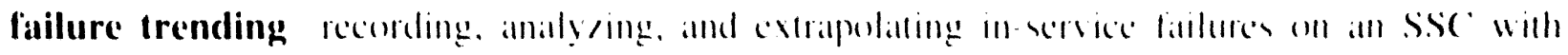

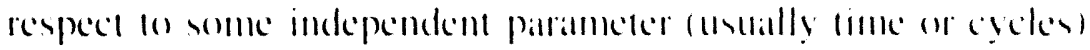

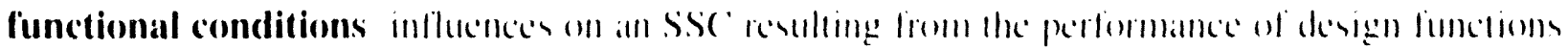
foperatson of a system or componeme and loading of a structure)

functional indicator condituon indicalor thall is a direce imdicalton of the current ability of ant SSc to function within acceptance critertat 
inservice inspection medhods and actions for assuring the structural and pressure-retaining

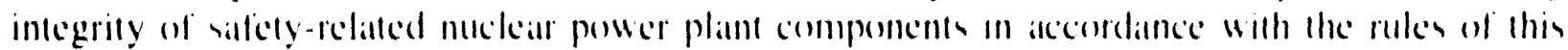
Section IAS.ME: Code. Section XII

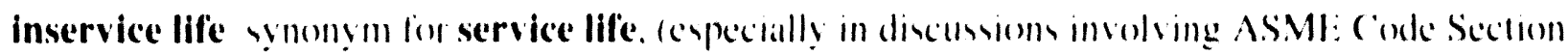
XII

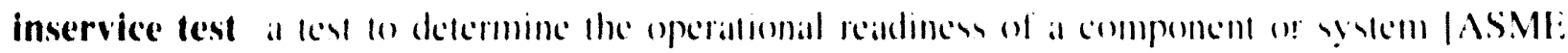
(inde. Section XI1

inspection younyill for surveillance

installed life period from inviallation lo retirement of an SSC

life period from liabricatton en relirement of an SSC

life assessment vinumym for aging assessment

life cycle management ỵnonỵm for life management

life management integration of aging management and ceconomic planning lo: 11 ) optimise the

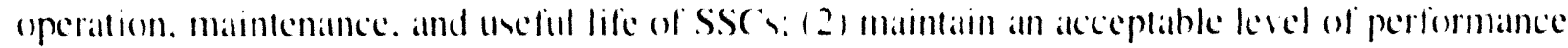
and safely: and 13 maximise return on inserment oree the useful life of the plant

lifetime unonym for life

maintenance aggregate of dired and supporting actoms that deted. prectude. or mitigate

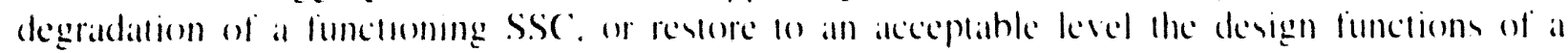
lanked SSC

malfunction unonyom for failure

mean time between failures arihmetic aterage of operatting limes hetween latilures of an $l l e m$ |IEEEE Sid $1(x) \mid$

natural aging aging of an SSe that accurs under preservice and exrice conditums. including crror-mduced condilions

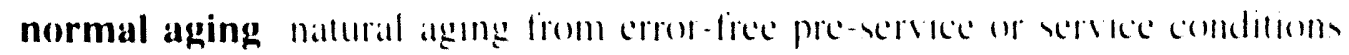

normal aging degradation agguge degradation produced hy mormal comditums

normal conditions operating conditions of a properly designed, fahricalted, imstalled, operated and manntanned SSC excluding design basis event conditions

normal operating conditions synonym for normal conditions 
normal stressor stressor that stems from normal conditions and cin produce aging mechanisms and effects in an SSC

operating conditions service conditions, including normal and error-induced conditions. prior to the start of a design basis accident or carthquake

operating service conditions synonym for operating conditions

operational conditions synonym for functional conditions

overhaul (noun) extensive repair, refurbishment, or both

performance indicator synonym for functional indicator

periodic maintenance form of preventive maintenance consisting of servicing, parts replacement, surveillance, or testing at predetermined intervals of calendar time, operating time. or number of cycles

planned maintenance form of preventive maintenance consisting of refurbishment of replacement that is scheduled and performed prior to failure of an SSC

post-maintenance testing testing after maintenance to verify that maintenance was performed correctly and that the SSC can function within acceptance criteria

preconditioning synonym for age conditioning

predictive maintenance form of preventive maintenance performed continuously or at intervals governed by observed condition to monitor. diagnose, or trend an SSC"s functional or condition indicators; results indicate current and future functional ahility or the nature and schedule for planned maintenance

premature aging aging effects of an SSC that occur earlier than expected hecause of errors or pre-service and service conditions not considered explicitly in design

pre-service conditions actual physical states or influences on an SSC prior to initial operation (e.g., fabrication, storage, transportation, installation, and pre-operational testing)

preventive maintenance actions that detect, preclude, or mitigate degradation of a functional SSC to sustain or extend its useful life by controlling degradation and failures 10 an acceptable level; there are three types of preventive maintenance: periodic, predictive, and planned.

qualified life period for which an SSC has heen demonstrated, through testing, analysis, or experience, 10 he capable of functioning within acceptance criteria during specified operating condittons while retaining the ability 10 perform its safety functions in a design hasis atcident or earthquake 
random failure any failure whose caltuse or mechanism, or hoth. make its lime of oceurrence unpredictable |IEEE Std l())|

reconditioning synonym for overhaul

refurbishment planned actions to improve the condition of an unfailed SSC

remaining design life period from a stated time 10 planned retirement of an SSC

remaining life actual period from a stated time lo retirement of an SSC

remaining service life synonym for remaining life

remaining useful life synonym for remaining life

repair actions to return a failed SSC 10 an atceptable condition

replacement removal of an undegraded, degraded. or failed SSc or a part thereof and installation of another in its place that can function within the original aceptance criteria

residual life synonym for remaining life

retirement final withdrawal from service of an SSC

rework correction of inadequately performed fabrication, installation. or maintenance

root cause fundamental reatsons for an oberved condition of an SSc that if corrected prevents recurrence of the condition

root cause analysis synomym for failure analysis

service conditions actual physical states or influences during the service life of an SSC.

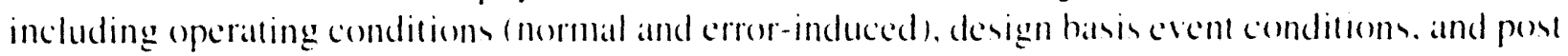
design hass event condiltoms

service life actual period from inutal operation to returement of an SSC

servicing routine ations (including ckeaning. adjustment. callibration. and replacement of consumable) that sustain or extend the uneful life of an SSC

simultaneous effects combined effects from stressors acting simultaneously

stress symonym for stressor

stressor agent or stimulus thall seme from pre-service and service conditions and can produce momediatc or ageng degradittion of an SSC 
surveillance observation or measurement of condition or functional indicators to verify that an SSC currently can function within acceptance criteria

surveillance requirements test, calibration, or inspection to assure that the necessary quality of systems and components is maintained, that facility operation will be within the safety limits, and that the limiting conditions of operation will be met |10 CFR 50.36] (for use only when specific regulatory and legal connotations are called for)

surveillance testing synonym for surveillance, surveillance requirements. and testing (use only when specific regulatory and legal connotations are called for)

synergistic effects portion of changes in characteristics of an SSC produced solely by the interaction of stressors acting simultaneously, as distinguished from changes produced by superposition from each stressor acting independently

testing observation or measurement of condition indicators under controlled conditions to verify that an SSC currently conforms to acceptance criteria

time in service time from initial operation of an SSC to a stated time

useful life synonym for service life

wearout failure produced by an aging mechanism

\section{References}

A.1 EPRI TR-100844, "Nuclear Power Plant Common Aging Terminology," prepared by MPR Associates, Inc., November 1992. 


\section{APPENDIX B ACRONYMS}

\begin{tabular}{|c|c|}
\hline AMG & Aging Management Guideline \\
\hline ARP & Annunciator response procedure \\
\hline ASME & American Society of Mechanical Engineers \\
\hline$B \& P V$ & Boiler and Pressure Vessel \\
\hline BWR & Boiling Water Reactor \\
\hline $\mathrm{CCW}$ & Closed Cooling Water \\
\hline CFR & Code of Federal Regulations \\
\hline CVC & Chemical and Volume Control \\
\hline CVCS & Chemical and Volume Control System \\
\hline $\mathrm{DOE}$ & U.S. Department of Energy \\
\hline dpa & Displacements per alom \\
\hline $\mathrm{ECC}$ & Emergency Core Cooling \\
\hline ECCS & Emergency Core Cooling System \\
\hline EDG & Emergency Diesel Generator \\
\hline EPRI & Electric Power Rescarch Institute \\
\hline $\mathrm{HPCI}$ & High-pressure coolant injection \\
\hline IASCC & Irradiation assisted stress corrosion cracking \\
\hline IGSCC & Intergranular streis corrosion cracking \\
\hline INPO & Institute for Nuclear Power Operations \\
\hline IPA & Integrated Plant Assessment \\
\hline IR & Industry report \\
\hline LCM & Life Cycle Management \\
\hline LER & Licensee Event Report \\
\hline LMTD & Logarithmic-Mean Temperature Difference \\
\hline LWR & Light Water Reactor \\
\hline MIC & Microbiological Influenced Corrosion \\
\hline MTD & Mean Temperature Difference \\
\hline NPAR & Nuclear Plant Aging Research \\
\hline NPRDS & Nuclear Plant Reliability Dala System \\
\hline
\end{tabular}


NRC U.S. Nuclear Regulatory Commission

NTU Number of Transfer Units

NUMARC Nuclear Management and Resource Council

O\&M Operations and Maintenance Code (ASME)

PLIM Plant Lifetime Improvement

PM preventive maintenance

pph Parts per billion

ppm Parts per million

PWR pressurized water reactor

RBCCW Reactor building closed cooling water

RCIC reactor core isolation coolling

RHR Residual Heat Removal

RWCU Reactor Water Cleanup

RWST Refueling water storage tank

SCs Structures and components

SCC Stress corrosion cracking

SHE Standard hydrogen electrode

SNL Sandia National Laboratories

SOER Significant Operating Experience Reports

SSCs Systems, structures, and components

TEMA Tubular Exchanger Manufacturers Association

TGSCC Transgranular stress corrosion cracking 
Distribution for Mechanical AM(is:

Category UC-523 (91 copies)

\section{DOE}

Dennis Harrison (5 copies)

U.S. Department of Energy, NE-4.51 1990)1 Germantown Road

Germantown, MD $2(1) 874$

Sterling Franks, III

U.S. Department of Energy, NE-45I 19901 Germantown Road

Germantown, MD 20874

Charles Thompson

U.S. Department of Energy, NE-45!

1990)1 Germantown Road

(icmantown, MD $2(1874$

David McCioff

U.S. Deparment of Energy, NE-4()

199()! Germantown Road

(iermantown, MD $2(1) 874$

Paul Wu (2 copies)

U.S. Department of Energy, NS-10 199()1 Germantown Road

Germantown, MD $2(1) 874$

$\underline{E P R I}$

John Carey (2 copies)

Electric Power Resealleh Institute

3412 Hillview Avenuc

Palo Alto, CA 9430)3

Mel Lapides

Electric Power Rescinch Institute

3412 Hillview Avente

Palo Alto, (A 94.30).3

Michael Downs

EPRI NMAC

1.3(1) Harris Boulevard

(harlotle, NC' 28262
John Jenco (2 copies)

EPRI NMAC

130) Harris Boulevard

Charlotte, NC $2 \times 262$

EPRI Life Cycle Management Subcommittee

Barth Doroshuk (2 copies)

Baltimore Gas \& Electric

Calvert Cliffs

Route 4 South

Lusby, MD 2(16.57

Deborah Staudinger

B\&W Nuclear

3315 Old Forest Road

Lynchburgh, VA $245(16$

Richard Remshaw (2 copics)

Project Manager

Consolidate Edison Co. of New York

4 lrving Place, Rm. 1238

New York, NY I0()(1)3

Greg Robison (4 copies)

Duke Power Company, ECogr

422 South Church Street

P.). Box $10(0) 6$

('harlotle, NC' 2820)1-10(1)6

W.I: Mashburn (2 copies)

Entergy Operations, Inc.

P. (). Box 31995

Jackson, MS 39280-1995

Roger Murgatroid (2 copies)

$1.5760)$ W. Power Line St. (MAC-NA2(i)

Florida Power Corporation

Crystal River, 11. 34428-6708

Kall Jacobs (10 copies)

New York Power Authority

123 Main Street

White Plains, NY 1060)] 
Distribution for Mechanical AMGs (Con't)

Francis Feng (3 copies)

Niagara Mohawk Power Corp.

301 Plainfield Road

Syracuse, NY 13212

Dana Korneman (2 copies)

Illinois Power Company

Clinton Power Station

P.O. Box 678

Clinton, IL 61727

Tim Bailey (2 copies)

Northern States Power Co.

Monticello Nuclear Generating Plant

2807 W. Highway 75

Monticello, MN 55362

Robert McDevitt

Nuclear Operations Support Dept.

Pacific Gas \& Electric Co.

77 Beale Street, Rm. 1414

San Francisco, CA 94106

Ray McNamara (2 copies)

Pennsylvania Power \& Light Company

Two North Ninth Street

Allentowri, PA 18101

Jim Perrin (3 copies)

Public Service Electric \& Gas Co.

P.O. Box 236, N32

Hancocks Bridge, N.J. (08038

Jose Perez (2 copies)

Southern California Edison

9975 Toledo Way

Suite 102

Irvine, CA 92718

John Giddens (4 copies)

Southern Nuclear Operating Co.

P.O. Box 1295

Birmingham, AL 35201-1295
John Swailes (7 copies)

Washington Public Supply Power System

P.O. Box 968

3000 George Washington Way

Richland, Washington 99352-0968

Chuck Krause (2 copies)

Wisconsin Electric Power Company

231 West Michigan

P.O. Box 2046

Milwaukee, WI 53201

NSSS Owners Group Liaisons

Phil Richardson (2 copies)

ABB-CE Owners Group

P.O. Box 500)

10(0) Prospect Hill Road

Windsor, Conn 06095

Deborah Staudinger (2 copies)

B\&W Owners Group GLRP Liaison

3315 Old Forest Road

Lynchburgh, V'A 24506

Chuck Pierce (2 copies)

BWR Owners Group GLRP Liaison

Southern Nuclear Operating Co.

P.O. Box 1295

Birmingham, AL 35201-1295

Roger Newton (2 copies)

Westinghouse Owners Group GLRP Liaison

Wisconsin Electric Power Co.

231 West Michigan, P.O. Box 2046

Milwaukee, WI 53201

Institute of Nuclear Power Opns

James R. Bauman

Institute of Nuclear Power Opns

110)() Circle 75 Parkway, Suite 1500)

Atlanta, GA 30339 
Distribution for Mechanical AM(is (Con't)

NRC Programs

Milton Vagins (2 copies)

U.S. Nuclear Regulatory Commission

565() Nicholson Lane

Rockville, MD 20852

Jit Vora (2 copies)

U.S. Nuclear Regulatory Commission

5650 Nicholson Lane

Rockville, MD 20852

NEI

Ray $\mathrm{Ng}$

NEI

1776 Eye Street, NW, Suite 3()()

Washington, DC 20(0)(6-2496

D. J. Walters

NEI

1776 Eye Street, NW, Suite 30)

Washington, DC 200(06-2496

Alexander Marion

NEI

1776 Eye Street, NW, Suite 3()()

Washington, DC 20(0)(6-2496

$\underline{\text { Utilities }}$

Robert Page (2 copies)

Palo Verde Nuclear Generating Station

Arizona Public Service Co.

P.O. Box 52034

Phoenix, AZ 85072

Carter Rogers

Sufety \& Licensing Division

Arizona Public Service Co.

Mail Station 1666

P.O. Box 53999

Phoenix, AZ 85(172-3999)
Barry Allen

Arkansas Nuclear One, Unit 1

Highway 64 West

P.O. Box $137 \mathrm{G}$

Russellville, AR 728()1
Al Morgan

Arkansas Nuclear One, Unit 2

Highway 64 West

P.O. Box 137G

Russellville, $A R$ 72801

Barry Tilden

Nuclear Engineering Department

Baltimore Gas \& Electric

Calvert Cliffs Nuclear Power Plant

1650 Calvert Cliffs Parkway

Lusby, MD 2(0657-47()2

Bruce Hagemeier (2 copies)

Boston Edison Co.

60) Rocky Hill Road \#PNPS

Plymouth, MA 0236()-5508

A. M. Lucas, Vice President

Nuclear Engineering Department

Carolina Power and Light Company

411 Fayetteville Street

P.O. Box 1551

Raleigh, NC 27602

Grant Chappell (4 copies)

Carolina Power \& Light Company

P.O. Box 1551

Raleigh, NC 276() 2

Dave Graneto (2 copies)

Maintenance Superintendent

10 Center Road

Mail Zone MB 210

Perry, $\mathrm{OH}$ 44081 
Distribution for Mechanical AM(is (Con't)

D. R. Eggett (14 copies)

Commonwealth Edison Company

1400) Opus Place, Suite 300)

Downers Grove, IL 60515

K!urt W. Uhlir

Commonwealth Edison Co.

1400) Opus Place, Suite 300)

Downers Grove, IL 60515

Thomas Buczwiaski (3 copies)

Consumers Power Company

27780 Blue Star Highway

Covert. MI 49085

Steve Booker ( 2 copies)

Assistant Maintenance Superintendent

Detroit Edison Company

6400) N. Dixie Hwy

Newport, MI 48166

Ted Huminski

Nuclear Engineering Dept.

Duquesne Light Company

P.O. Box 321

Shippingport, PA $15(177$

John Sieber

Vice President, Nuclear Group

Duquesne Light Company

30)1 Grant Street, 1 Oxford Centre

Pittsburg, PA 15279)

J. H. Spiegel

Duquesne Light Company

BV-A

P.O. Box 4

Shippingport, PA 15077

Bill Brice

Entergy Operations, Inc.

Grand Gulf Nuclear Station

P.O. Box 756

Port Gibson, MS 39105
Shawn Tyler

Forida Power Corp.

Crystal River Nuclear Power Plant

NAIE

P.O. Box 219

Crystal River, FL 32623-(1219

J. C. Winborne, Jr.

Florida Power Corp.

Crystal River Nuclear Power Plant

NA1E, P.O. Box 219

Crystal River, FL 32623-(1219

Edward Wienkam, III (3 copies)

Licensing Mgr., Turkey Point

Florida Power \& Light Co.

P.O. Box $(229100$

Miami, Fl. 331(22-9100

Robert Locke (3 copies)

GPU Nuclear

1 Upper Pond Road

Parsippany, NJ (07054

Williams Simmons

Gulf States Utilities

River Bend Station

North Access Road

P.O. Box 220)

St. Francisville, LA 70775

Steven Rosen ( 2 copies)

Vice President, Nuclear Engineering

\& Construction

Houston Lighting \& Power

P.O. Box 289

Wadsworth, TX 77483

Gary Mathews

Illinois Power Co.

Clinton Power Station

P.O. Box 678

Route 54 - 6 Miles East

Clinton, IL 61727 
Distribution for Mechanical AM(is (Con't)

Tom Augustyn (2 copies)

Indiana/Michigan Power

D.C. Cook Nuclear Power Plant

1 Cook Place

Bridgeman, MI 49106

Steve Catron

lowa Electric Light \& Power Co.

Duane Amold Energy Center

3277 DAEC Road

Palo, IA 52324

T. C. Su

Iowa Electric Light \& Power Co.

Duane Arnold Energy Center

3277 DAEC Road

Palo, IA 52324

Don Marpe

Louisiana Power \& Light

Waterford 3 Station

P.O. Box B

Killona, LA 70066

Robert Lawton, Jr.

Maine Yankee Atomic Power

P.O. Box 408

Wiscasset, ME ()4578

Jim Hackney

Nebraska Public Power District

1414 - 15th Street

Box 499

Columbus, NE $680(0) 1$

Ron Fish

New York Power Authority

123 Main Street

White Plains, NY $106(0)$
Robert Wilber

Division Manager

Nuclear Engineering \& Construction

Nebraska Public Power District

141415 th Street

Columbus, NE 6860)1

Tom Cleary

Northeast Utilities

P.O. Box 270)

Hartford, CT (06141-(1270)

Rich Kacich (2 copies)

Manager, licensing

Northeast Utilities

P.O. Box 27()

Hantford, CT (16141-(1270)

Tim McDonald

Maintenance Supervisor

Connecticut Yankee Allantic Power Co.

362 Injun Hollow Rd.

East Hampton, CT 06424

Jerry Peterson

Maintenance Manager

New Hampshire Yankee

Seabrook Generating Station

P.O. Box 3(0)

Seabrook, NH 0.3874

Neil Bergh

Maintenance Manager

Millstone Unit 1

P.O. Box 128

Waterford, CT 06385

Richic Hall

Maintenance Supervisor

Millstone Unit 2

P.O. Box 128

Waterford, CT 06.385 
Distribution for Mechanical AMCis (Con't)

Paul Atkinson

Maintenance Supervisor

Millstone Unit 3

P.O. Box 128

Waterford, CT 06385

Rich Scofield

Manager, Nuclear Planning

Omaha Public Power District

444 S. 16th Street Mall

Omaha, NE 68102

Dennis Cox

Nuclear Engineering, Safety \& Licensing

Palo Verde Nuclear Power Project

23 Parker Street

Irvine, CA 92718

D. A. Cronomiz (3 copies)

Nuclear Engineering Department

Philadelphia Electric Company

965 Chesterbrook Boulevard, M/C 63B-1

Wayne, PA 19087-5691

Jack Maddox

Director, Resources \& Nuclear Services

Public Service Co. of New Mexico

Alvarado Square

Albuquerque, NM 87158

David K. Summers

Public Service Co. of New Mexico

Alvarado Square

Albuquerque, NM 87158

Jeremiah Whooley

Engineering and Construction Department

Public Service Electric \& Gas Co.

80 Park Plaza

P.O. Box 570

Newark, NJ (07101
Bruce Snow (2 copies)

Chief Engineer

Rochester Gas \& Electric Co.

89 East Avenue

Rochester, NY 14694

Stan Crumbo

Sr. Engineer Equipment

Quantification (MC805)

South Carolina Electric \& Gas Co.

P.O. Box 88

Jenkinsville, SC 29065

David Pilmer (2 copies)

Manager, Nuclear Engineering

Southern California Edison

2364 Walnut Grove Avenue

Rosemead, CA 91770

Randall Weir (4 copies)

Tennessee Valley Authority

1101 Market Street, LP4F

Chattanooga, TN 374() 2

Jacob M. Kulangara

Texas Utility Electric Co.

40() $\mathrm{N}$. Olive Street

Box 81

Dallas, TX 75201

John Marshall (2 copies)

Generic Licensing Manager

Texas Utility Electric Co.

400 N. Olive Street (LB-81)

Dallas, TX 75201

John A. Fehl

Toledo Edison Co.

Davis-Besse Nuclear Power Station

30) Madison Avenue

Mail Stop: 1056

Toledo, $\mathrm{OH} 43652$ 
Distribution for Mechanical AMGis (Con't)

James Long

Toledo Edison Co.

Mail Stop 10.37

Davis-Besse Nuclear Power Station

5.5() 1 State Route 2

Oak Harbor. OH 43449)

Roger Dettenmeier (2 copies)

Senior Engineer

Union Electric Co.

P.O. Box 149, MC 47()

St. Louis, MO 6.3166

James $S$. Johnson

Union Electric Company

P.O. Box 149

St. Louis, MO 6.3166

Mike Metall

Vermont Yankee

RD 5, Box 169

Old Ferry Road

Brattleboro, VT (1)3.3()1

Joe Hegner (3 copies)

Virginia Power Company

Innsbrook Technical Center

50() 0 Dominion Blvd.

Gen Allen, VA 23060)

Tom Erwin

Washington Public Power Supply System

P.O. Box 968 (MS PE25)

Richland, WA 99352

Neil Zimmerman

Washington Public Power Supply System

P.O. Box 968 (MD PE 27)

Richland, WA 99352

Robert Powell

Washington Public Power Supply System

P.O. Box 968, MD PE 27

Richland WA 99352
Dave Andreoni

Wisconsin Electric Power Co.

Point Beach Nuclear Plant

6610 Nuclear Road

Two Rivers, WI 54241-9516

Duane Schoon

Wisconsin Electric Power Company

231 West Michigan

P.O. Box 2046

Milwaukee, WI 5.3201

John Richmond (2 copies)

Wisconsin Public Service

P.O. Box 19002

6()) North Adams St.

Green Bay, WI $543(1) 7$

Mr. Bant Withers

President \& CEO

Wolf Creek Nuclear Operating Plant

P.O. Box 411

Burlington, KS 668.39

Dave Glowoski

Wolf Creek Nuclear Operating Plant

P.O. Box 411

Burlington, KS 668.39

Royce MacMahon

Wolf Creek Nuclear Operating Plant

P.O. Box 411

Burlington, KS 668.39

Max Nichols

Wolf Creek Nuclear Operating Plant

P.O. Box 411

Burlington, KS 668.39

Tim Smith

Wolf Creek Nuclear Operating Plant

P.O. Box 411

Burlington, KS $\quad(68839$ 
Distribution for Mechanical AM(is (Con't)

NSSS Vendors and Consultants

Dr. Robert Nickell

AST

16630) Sagewood Lane

Poway, CA 92()64

James Williams

B\&W Nuclear 'Technologies

P.O. Box 1(19)35

Lynchburgh, VA $245(16-(1) 935$

Kathy Berry

General Electric Nuclear Energy

175 Curtner Ave., MC 789

San Jose, CA 95125

Charles Negin

Grove Engineering

15215 Shady Grove Road, Suite 2(1)

Rockville, MD 2085()

Alton P. Donnell, Jr.

Ogden Environmental and Energy Services 73()1-A Indian School Rd., NE

Albuquerque, NM 87110

Gary Toman

Ogden Environmental and Energy Services

1777 Sentry Parkway West

Abington Hall, Suite 30)(

Blue Bell, PA 19422

Steve Booker

MDC-Ogden Envirommental and Energy

Services

29200 Southfield Road, Suite 103

Southfield, MI $48(076$

Neil Daavettila

MDC-Ogden Environmental and Energy

Services

29200) Southfield Road, Suite 103

Southfield, MI $48(076$
Esther Palop

MDC-Ogden Envirommental and Energy

Services

2920)() Southfield Road, Suite 1033

Soutlifield, MI $48(076$

Daniel Lehnent

MDC-Ogden Environmental and Energy

Services

2920() Southfield Road, Suite 10.3

Southfield, MI 48076

Jim Nightingale

PRC Engineering Systems, Inc.

4343 Commerce Court, Suite 215

Lisle, IL 605.32

Tricia Heroux

Regulatory Management

6419 22nd St., N

Arlington, VA 2220.5

Lynn Connor

STS

3 Metro Center, Suite 610

Bethesda, MD 20814

Vic Miselis

Westinghouse Electric Corporation

P.O. Box 355

Pittsburgh, PA 15230

Gilbert/Commonwealth, Inc.

Library and Information Services

P.O. Box 1498

Reading PA 19603-1498

Ahmed Meligi (24D39)

Sargent \& Lundy Engineers

55E. Monroe Street

Chicago, IL 60603 
Distribution for Mechanical AMCis (Con't)

Hunt Armistead (2 copies)

City of Austin, Electrical Department

721 Barton Springs Road

Austin, Texas, 787(1)4

Paul Yela

Westinghouse Idaho Nuclear Company

MS5231, P.O. Box 4()()()

Idaho Falls, ID 8.341 .5

Attr: Gina Bailey

Sandia (Internal)

MS 07.36 N. R. Ortiz. (640)())

MS 0744 W. A. von Riesemann (640)3)

MS 0741 A. K. Moonka (6471)

MS 0741 J. M. Clauss (6471)

MS (1741 J. T. Nakos (647I) (15 copies)

MS (0741 S. T. Rosinski (6471)

MS (0753 R. R. Hill (6218)

MS 0899 Technical Library $(7141)(5$ copies $)$

MS (0619 Technical Publications (7151)

MS 9018 Central Technical Files (8523-2)

MS 0100 Document Processing for DOE/OSTI (10 copies) 

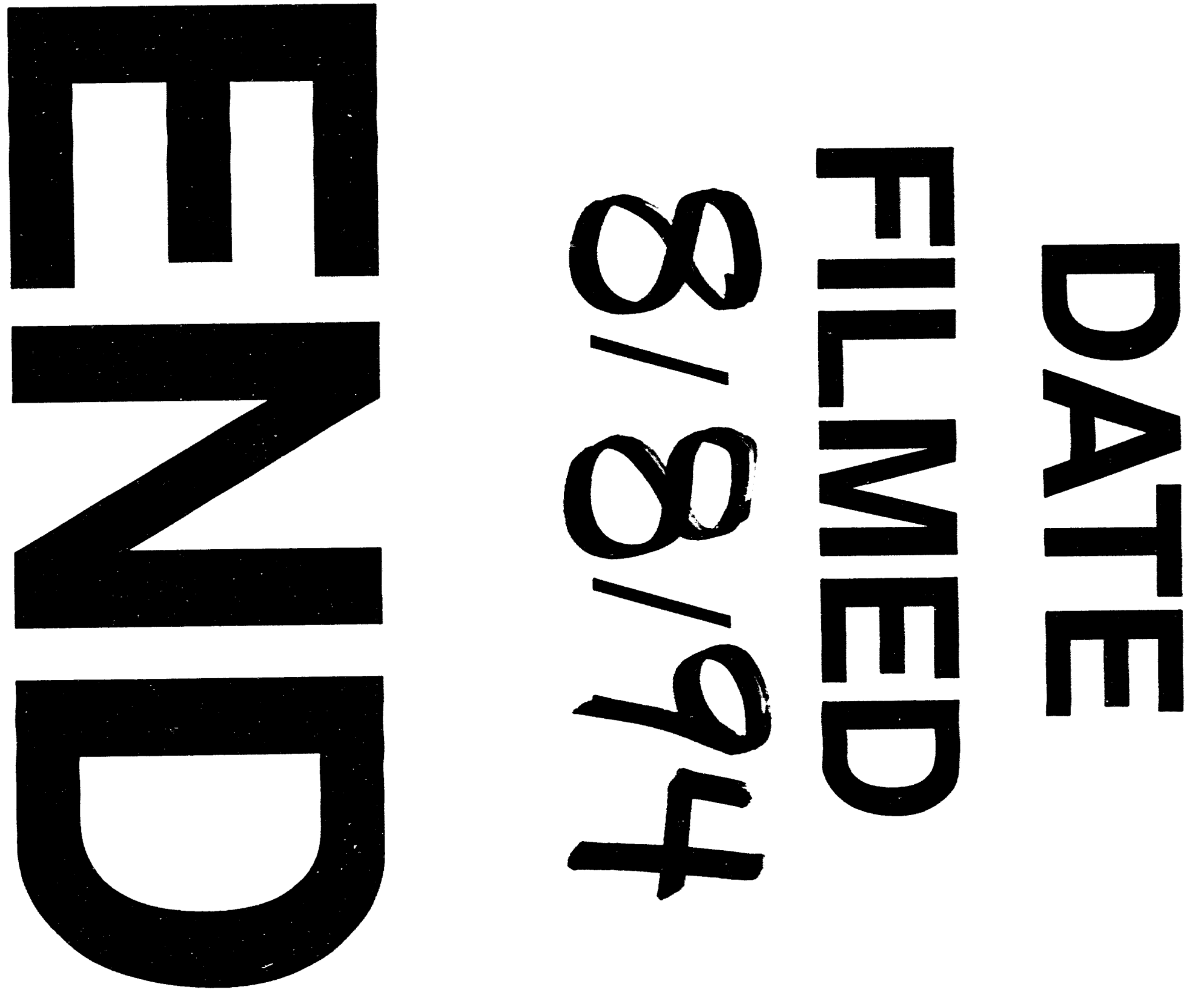
